15. DOE/ID/12757--1

DE91 013155

\title{
THE MOANA GEOTHERMAL SYSTEM IN RENO, NEVADA: A HYDROLOGIC, GEOCHEMICAL, AND THERMAL ANALYSIS
}

\author{
Prepared by \\ Elizabeth A. Jacobson ${ }^{1}$ \\ Jeffrey W. Johnston ${ }^{2}$ \\ Desert Research Institute \\ Water Resources Center \\ University of Nevada System
}

Publication \#41131

Prepared for

The U.S. Department of Energy

Geothermal Division

State Cooperative Geothermal Research

Grant Number DE-FG07-88ID12757

March 1991

${ }^{1}$ Assistant Research Professor, Water Resources Center, Reno, Nevada

${ }^{2}$ Graduate Research Fellow, Water Resources Center, Reno, Nevada 


\section{DISCLAIMER}

This report was prepared as an account of work sponsored by an agency of the United States Government. Neither the United States Government nor any agency Thereof, nor any of their employees, makes any warranty, express or implied, or assumes any legal liability or responsibility for the accuracy, completeness, or usefulness of any information, apparatus, product, or process disclosed, or represents that its use would not infringe privately owned rights. Reference herein to any specific commercial product, process, or service by trade name, trademark, manufacturer, or otherwise does not necessarily constitute or imply its endorsement, recommendation, or favoring by the United States Government or any agency thereof. The views and opinions of authors expressed herein do not necessarily state or reflect those of the United States Government or any agency thereof. 


\section{DISCLAIMER}

Portions of this document may be illegible in electronic image products. Images are produced from the best available original document. 


\begin{abstract}
The Moana geothermal system, located in Reno, Nevada, is a moderate-temperature geothermal resource used for space heating applications. Both historic and new hydrologic, thermal, and groundwater chemistry data were collected to evaluate the Moana system and to develop a calibrated numerical model of the geothermal aquifer for investigation of resource development scenarios. The new data collection consisted of static water level measurements and temperature with depth measurements for a 13-month period at 26 geothermal wells to investigate hydrologic and thermal changes with time. In addition, groundwater chemistry sampling at 10 wells was used to evaluate mixing of thermal and nonthermal waters. A comparison of historic static water levels to those collected for this study indicates that in the most heavily used portion of the geothermal aquifer, the hydraulic heads have declined. This decline in hydraulic heads may induce additional leakage of cooler water from the overlying unconfined aquifer and thus, lead to decreased temperatures at well locations in the geothermal aquifer. The groundwater chemistry data show concentration changes with temperature for boron, chloride, fluoride, lithium, and bicarbonate that are a function of the degree of mixing of thermal and nonthermal waters. Temporal changes in these constituents may be used as an indication of relative temperature changes in the geothermal system caused by mixing at a given location. Obtaining representative measurements of reservoir temperature changes from wells used for heating is not possible due to the downhole hardware and heat load demands. Thus, a technique based on the use of temporal changes in chemical data at wells to indicate temperature changes at those locations shows great promise. An attempt was made to use the hydraulic head and maximum temperature data to develop a calibrated numerical model for the Moana geothermal system. However, lack of information about the horizontal and vertical thermal and fluid fluxes made the development of a calibrated model not possible at this time.
\end{abstract}




\section{ACKNOWLEDGEMENTS}

Funding for this work was provided by the U.S. Department of Energy (Grant No. DE-FG07-88ID12757). The Water Resources Center of the Desert Research Institute (DRI) University of Nevada System, provided cost sharing funds.

We wish to express our thanks to the homeowners who allowed us to take measurements at their geothermal wells; to Francis McKay of McKay Drilling Inc. and Dr. Thomas Flynn of Division of Earth Sciences, University of Nevada, Las Vegas for providing information and data; W. Alan McKay of the Water Resources Center, DRI for his help in the data collection portion of this study and his technical comments during the project; and to Brad Lyles of the Water Resources Center, DRI for his help in calculating the geothermometer temperatures.

Dr. Michael Campana of the University of New Mexico (formerly of DRI) was the originator of this research grant. We wish to thank our internal technical reviewers, Alan McKay and John Fordham of DRI, and the external technical reviewers, Dr. Howard Ross and Dr. Joseph Moore of the Earth Science Laboratory, University of Utah Research Institute and Dr. Marshall Reed of the U.S. Department of Energy, Washington D.C. for their comments on our final report. Our thanks also go to Marjory Jones for her editorial review, Barbara Nauroth and Deborah Wilson for their excellent preparation of this report, and Jan Walker for her drafting expertise.

Special thanks go to Karla Cosens of DRI and Kenneth J. Taylor, Elizabeth M. Bowhan, and Trudy Thorne of the U.S. Department of Energy, Idaho Operations Office, and Dr. Howard Ross of the Earth Science Laboratory, University of Utah Research for all their help with the administrative aspects of this project. 


\section{EXECUTIVE SUMMARY}

The Moana geothermal area is located in northwestern Nevada, mostly within the City of Reno. A shallow (100 to $200 \mathrm{ft}$ ), low to moderate temperature $\left(45\right.$ to $98^{\circ} \mathrm{C}$ ), geothermal aquifer is utilized for residential and commercial heating purposes. Currently, more than 160 wells extract heat and hot water from the geothermal aquifer in an area of less than 5 square miles.

Development of the geothermal aquifer was on a limited scale through 1975 when 35 homes and 3 businesses utilized the resource (Bateman and Scheibach, 1975). During the late 1970s and early 1980s, the Moana area experienced a small boom in geothermal development. Numerous domestic geothermal wells were completed and two district heating systems were brought on line during this period. Today the resource is exploited by over 200 residences, numerous businesses, and several churches. Development of the geothermal area has progressed in an uncoordinated manner which may affect the quality of the resource. Cessation of flowing artesian conditions in the resource area was observed by Ghusn (1982) during the early 1980s. The reduction in aquifer pressure suggests that the resource area is experiencing some degree of development stress. To investigate the impact of development, a research grant was received from the United States Department of Energy, Idaho Operations Office, to evaluate and simulate the Moana geothermal system.

The objectives of the research are to compile and evaluate historical data, collect additional data for one full heating year and, based on this information, develop a numerical model of the Moana geothermal system using the U.S. Geological Survey (USGS) numerical code SUTRA. The ultimate objective is to construct and calibrate the numerical model of the Moana geothermal system to simulate the reservoir for a number of development scenarios for use by developers and regulators.

In July 1988, the research program began with the compilation and evaluation of all available hydraulic, thermal, well, geologic, chemical, and hydrologic historical data. The historical data were fragmented in time such that we were not able to construct spatially distributed hydraulic head or temperature maps with time. Although there are over 188 geothermal wells in the study area, data from many well logs were incomplete or very qualitative. Following the collection and evaluation of the available data, a preliminary sampling design was developed consisting of preferred locations in the Moana geothermal system. The owners of the geothermal wells were contacted to gain permission to measure water level and temperatures in their wells for the one heating cycle of 13 months. This process required several months to obtain a final set of 28 locations and in January 1989, the monitoring began on a consistent set of wells. During the 13-month monitoring period, two wells were dropped from the study group at the request of the homeowners. The data collection phase of the project was completed in February 1990. 
Water levels and temperature with depth were collected for a 13-month period at the 26 geothermal wells. Analysis of these data suggests that in the central portion of the study area where there is a high density of wells with pumps, the water levels have declined with time. The monitoring well at Horseman's Park upgradient of the main resource area shows a water level increase of $5 \mathrm{ft}$ between 1984 and 1989. The monitoring well at Manzanita Park that is generally downgradient of the main resource area also shows a decrease in water level since 1984. Based on this information, pumping of wells in the Moana geothermal area is impacting the hydraulic heads (or aquifer pressures) near these wells.

The analysis of the temperature with depth data collected during this study indicated that well construction has an impact on the temperature measurement. The maximum temperature measured at the geothermal wells was influenced by the downhole hardware such as heat exchangers. Thus, the maximum temperature measured is likely to be less than the value in the reservoir. For the two monitoring wells at Horseman's Park and Manzanita Park, the temperature with depth data measured for this study was relatively constant with heating and nonheating season and are very similar to the data obtained by Flynn and Ghusn (1984).

The groundwater chemistry indicates a mixing of thermal and nonthermal waters which agrees with the isotopic results of Flynn and Ghusn (1984). The concentration with temperature relationships for various soluble elements, such as boron and chloride, could be used to indicate, in a relative sense, temperature changes in the geothermal reservoir at a given location. Obtaining representative measurements of reservoir temperature changes from geothermal wells used for heating is not possible due to the downhole hardware and heat load demands. However, a technique based on the use of temporal changes in chemical data at geothermal wells to indicate temperature changes at those locations shows great promise. The analysis of groundwater chemistry with time at 10 geothermal wells gave no clear indication of spatial patterns of temperature change.

The information obtained from both the historical data and the 13-month data collection phase of this project indicates that there are horizontal and vertical thermal and fluid fluxes in the Moana geothermal system. The attempt to develop a calibrated two-dimensional, steady-state numerical model of the Moana geothermal aquifer was hampered by a lack of information concerning the thermal and fluid fluxes which lead to an unconstrained problem. The observed temperature gradients could be locally reproduced by adding heat at the faults and removing heat at nearby nodes in a trial and error process. However, the quantity of heat added and removed could not be justified or compared to any measurements of thermal or fluid fluxes. Therefore, the development of a calibrated numerical model of the Moana geothermal aquifer is not possible at this time with the available data. Detailed information about the horizontal and ver- 
tical thermal and fluid fluxes is necessary before a calibrated numerical model can be developed. In addition, more geologic and hydrologic information for the Moana geothermal aquifer needs to be obtained before a predictive numerical model could be used to investigate resource development scenarios. The primary resource development scenario identified during this research is the continued and possible expansion of pumping at the geothermal wells. The current pumpage has produced decreases in hydraulic head in the center of the study area. These hydraulic head changes may, in time, have an adverse impact on the geothermal system by inducing additional leakage of cooler water from the nonthermal aquifer. To predict the impact, a calibrated model of the Moana geothermal system, together with the location and rates of pumping, will be needed. Currently, no measurements of pumping rates are available for geothermal wells used for home heating purposes.

Several recommendations can be made based on the analysis of the water level, temperature, and groundwater chemistry data from this project. Further monitoring of the Moana geothermal system should involve measurements on an annual basis of: 1) depth to water at selected geothermal wells to observe hydraulic head changes with time; and 2) groundwater chemistry at selected wells to indicate relative changes in temperature.

To develop a calibrated numerical model of the Moana geothermal system for investigation of development scenarios, the following additional data are needed:

1. detailed geological information on the geothermal aquifer;

2. measurements or estimates of hydraulic properties of the aquifer materials;

3. spatial distribution of thickness of layer between the geothermal and unconfined aquifers;

4. hydraulic conductivity of the layer between the two aquifers;

5. thermal conductivity of the layer between the two aquifers;

6. spatial distribution of hydraulic heads in the overlying unconfined aquifer;

7. spatial distribution of temperatures in the overlying unconfined aquifer; and

8. location and rate of pumping in the geothermal wells.

The Moana geothermal system has extremely variable geology, hydrology, and thermal components. Thus, the development of a numerical model to reliably predict the behavior of the geothermal system requires an extensive data collection effort far in excess of that undertaken for this project. 


\section{CONTENTS}

ABSTRACT

ACKNOWLEDGEMENTS

EXECUTIVE SUMMARY iv

INTRODUCTION 1

DESCRIPTION OF THE MOANA GEOTHERMAL SYSTEM

Sources of Data $\quad 2$

Geologic Setting $\quad 2$

Geothermal Aquifer $\quad 6$

Aquifer Testing $\quad 8$

Temperature Data $\quad 10$

Fluid Chemistry $\quad 13$

Nonthermal Water $\quad 13$

Thermal Water 15

Mixing 16

Direct Use 16

DATA COLLECTION 19

Thermal Data $\quad 19$

Water Level Data 33

GROUNDWATER CHEMISTRY 49

Chemical Composition $\quad 49$

Mixing $\quad 49$

Temporal Variation $\quad 61$

Seasonal Variation $\quad 61$

$\begin{array}{ll}\text { Long-Term Variation } & 67\end{array}$

Chemical Geothermometers $\quad 74$

NUMERICAL MODELING OF MOANA GEOTHERMAL SYSTEM 79

Conceptual Model $\quad 79$

Numerical Model and Input Data $\quad 81$

Results of Preliminary Steady-State Modeling $\quad 83$

Discussion $\quad 85$

$\begin{array}{ll}\text { CONCLUSIONS AND RECOMMENDATIONS } & 87\end{array}$

REFERENCES 90

APPENDICES

I. Well Types 92

II. Heating and Nonheating Temperature with Depth Profiles for All Wells in the Study Group 96

III. Static Water Levels with Time for All Wells in the Study Group 123

IV. SUTRA Input Files $\quad 150$ 


\section{FIGURES}

1. Location Map Showing the Moana Geothermal Area in the Truckee Meadows.

2. Geologic Map of the Moana Area.

3. Lateral Leakage Model for Low and Intermediate Temperature Hydrothermal Resources.

4. Piezometer Surface Elevations of Thermal Fluids in Moana.

5. Lithologic Log and Temperature-Depth Profile for the Monitoring Well at Horseman's Park.

6. Lithologic Log and Temperature-Depth Profile for the Monitoring Well at Manzanita Park.

7. Location of Geothermal Wells in the Moana Geothermal Area.

8. Location of the 26 Geothermal Wells Included in the Study Group from which Water Level and Temperature Data were Collected.

9. Heating and Nonheating Temperature with Depth Profiles for Well 10.

10. Heating and Nonheating Temperature with Depth Profiles for Well 6.

11. Heating and Nonheating Temperature with Depth Profiles for Well 1.

12. Heating and Nonheating Temperature with Depth Profiles for Well 14.

13. Heating and Nonheating Temperature with Depth Profiles for Well 15.

14. Heating and Nonheating Temperature with Depth Profiles for Well 17.

15. Heating and Nonheating Temperature with Depth Profiles for Well 22.

16. Heating and Nonheating Temperature with Depth Profiles for Well 24. 
17. Heating and Nonheating Temperature with Depth Profiles for Horseman's Park.

18. Heating and Nonheating Temperature with Depth Profiles for Manzanita Park.

19. Static Water Level with Time for Well 4.

20. Static Water Level with Time for Well 8.

21. Static Water Level with Time for Well 10.

22. Static Water Level with Time for Well 15.

23. Static Water Level with Time for Well 14.

24. Static Water Level with Time for Well 16.

25. Static Water Level with Time for Well 17.

26. Static Water Level with Time for Well 18.

27. Static Water Level with Time for Well 22.

28. Static Water Level with Time for Well 21.

29. Static Water Level with Time for Manzanita Park.

30. Static Water Level with Time for Horseman's Park.

31. Contours of Hydraulic Head in the Moana Geothermal Area for September 1989.

32. Boron Concentration with Temperature for Groundwater from the Moana Geothermal Area.

33. Chloride Concentration with Temperature for Groundwater from the Moana Geothermal Area.

34. Fluoride Concentration with Temperature for Groundwater from the Moana Geothermal Area.

35. Lithium Concentration with Temperature for Groundwater from the Moana Geothermal Area.

36. Arsenic Concentration with Temperature for Groundwater from the Moana Geothermal Area. 
37. Bicarbonate Concentration with Temperature for Groundwater from the Moana Geothermal Area.

38. Chloride-Boron Ratio with Temperature for Groundwater from the Moana Geothermal Area.

39. Bicarbonate-Chloride Ratio with Temperature for Groundwater from the Moana Geothermal Area.

40. Bicarbonate and Chloride Concentrations with Temperature for Groundwater Samples Collected by DRI for this Project from the Moana Geothermal Area.

41. Chloride Concentration with Time for the Virginia Lake Townhouse Geothermal Well.

42. Bicarbonate-Chloride Ratio with Time for the Virginia Lake Townhouse Geothermal Well.

43. Chloride Concentration with Time for the Sierra Geothermal Well.

44. Bicarbonate-Chloride Ratio with Time for the Sierra Geothermal Well.

45. Location of 10 Geothermal Wells in the Moana Geothermal Area from which Chemical Data were Collected.

46. Temporal Variations in Bicarbonate-Chloride Ratio versus Chloride Concentration for Well B, Well I, Well C, and Well G.

47. Temporal Variations in Bicarbonate-Chloride Ratio versus Boron Concentration for Well B, Well I, Well C, and Well G.

48. Temporal Variations in Bicarbonate-Chloride Ratio versus Chloride Concentration for Well $\mathrm{H}$, Well $\mathrm{F}$, and Well $\mathrm{J}$.

49. Temporal Variations in Bicarbonate-Chloride Ratio versus Boron Concentration for Well H, Well F, and Well J.

50. Temporal Variations in Bicarbonate-Chloride Ratio versus Chloride Concentration for Well $\mathrm{H}$, Well $\mathrm{D}$, and Well $\mathrm{E}$.

51. Temporal Variations in Bicarbonate-Chloride Ratio versus Boron Concentration for Well A, Well D, and Well E. 
52. Schematic of Fluxes of Water in the Conceptual Model of the Moana Geothermal System.

53. Spatial Distribution of Temperature $\left({ }^{\circ} \mathrm{C}\right)$ for September 1989 for the Moana Geothermal Area.

54. Finite Element Grid for Modeling of the Moana Geothermal Area. 


\section{TABLES}

1. Typical Thermal and Nonthermal Waters in the Moana Geothermal Resource Area.

2. Chemical Analyses of Nonthermal Waters from the Southern and Eastern Boundaries of the Moana Geothermal Area.

3. Chemical Analyses of Thermal Waters from the Moana Geothermal Area.

4. Comparison of Seasonal Chemical Analyses in Geothermal Waters.

5. Comparison of 1974 and 1989 Chemical Analyses of Geothermal Waters.

6. Comparison of Measured Temperatures to Estimates Obtained from Chemical Geothermometers. 


\section{INTRODUCTION}

This report describes the results of a research grant received from the United States Department of Energy, Idaho Operations Office (grant no. DE-FG07-88ID12757) to evaluate and simulate the Moana geothermal system located in Reno, Nevada. The objectives of the research are to compile and evaluate historical data, collect additional data for one full heating year and, based on this information, develop a numerical model of the Moana geothermal system using the U.S. Geological Survey (USGS) numerical code SUTRA. The ultimate objective is to construct and calibrate the numerical model of the Moana geothermal system to simulate the geothermal reservoir for a number of development scenarios for use by developers and regulators.

In July 1988, the research program began with the compilation of all available hydraulic, thermal, well, geologic, hydrochemical, and hydrologic data. A description of the sources of data for the Moana geothermal system and of the types of data is found in the following section. Following the collection and evaluation of the available data, a preliminary sampling design was developed consisting of preferred locations in the Moana geothermal system. The owners of the geothermal wells were contacted to gain permission to measure water level and temperatures in their wells for one heating cycle of 13 months. This process required several months to obtain a final set of 28 locations and in January 1989, the monitoring began on a consistent set of wells. During the 13-month monitoring period, two wells were dropped from the study group at the request of the homeowners. The data collection phase of the project was completed in February 1990. The section entitled "Data Collection" discusses the water level and thermal data collected for this study, and the interpretation of the data. Temporal variations in the collected groundwater chemistry data are presented in the next section, together with a discussion of the relationship between the water chemistry and the mixing of thermal and nonthermal waters. Information on the location and type of geothermal wells that were monitored is presented in Appendix I. Temperature with depth data for a heating and nonheating month for each sampled well is given in Appendix II. Appendix III contains the information on water level changes with time for each sampled well.

After evaluation of the new data, the next phase of the project consisted of constructing the conceptual and numerical models of the Moana geothermal system. The results of this phase of the research project are presented in the section on numerical modeling. The SUTRA input files are included in Appendix IV. The final section of the report contains the conclusions and recommendations. 


\section{DESCRIPTION OF THE MOANA GEOTHERMAL SYSTEM}

The first phase of this project consisted of collecting and assessing the quality of all available data on the Moana geothermal area. The purpose of this phase was to identify any gaps or discrepancies that existed in the current database. Identification of discrepancies aided in the design and implementation of the data collection phase of the project.

\section{SOURCES OF DATA}

Data on the Moana geothermal area were collected from a variety of sources. These sources can be classified into four general groups: 1) research organizations; 2) regulatory agencies; 3) consultants; and 4) drillers. Research organizations that have worked in the Moana area include: USGS, Division of Earth Sciences of the University of Nevada, Las Vegas (UNLV), Nevada Bureau of Mines and Geology (NBMG), Oregon Institute of Technology (OIT), and Desert Research Institute (DRI). Regulatory agencies which have an interest in the Moana geothermal resource area are Nevada Division of Environmental Protection (NDEP), Nevada Department of Minerals, and Nevada Department of Conservation and Natural Resources, Division of Water Resources. Consultants who have worked in the Moana area are William E. Nork, Inc. and REMCO. Drillers that are currently active in the area include McKay Drilling and Aqua Drilling.

A large amount of data was collected from the above sources. Data format included published reports, unpublished consulting reports, environmental compliance documents, permit applications and drillers' logs. All data were subsequently reviewed and analyzed. The following sections summarize the different types of data available on the Moana geothermal area.

\section{GEOLOGIC SETTING}

The Moana geothermal area is located in the Truckee Meadows, a north-southtrending basin at the western edge of the Basin and Range physiographic province. The Truckee Meadows are bounded on the west by the Carson Range, a spur of the Sierra Nevada, and on the east by the Virginia Range. Stratigraphic evidence suggests that the basin has been in existence since the early or middle Pliocene (Scheibach, 1975).

A location map showing the low-temperature Moana geothermal system is given in Figure 1. Another geothermal system located north of the Steamboat Hills is a hightemperature geothermal system that is used for geothermal electric power production. The Moana and Steamboat geothermal systems were investigated by Flynn and Ghusn (1984) and found to have different temperatures, water chemistry and age of the geothermal fluids. Thus, based on this information, the Moana and Steamboat geothermal systems are assumed to be two separate systems and are treated as such for this study. 


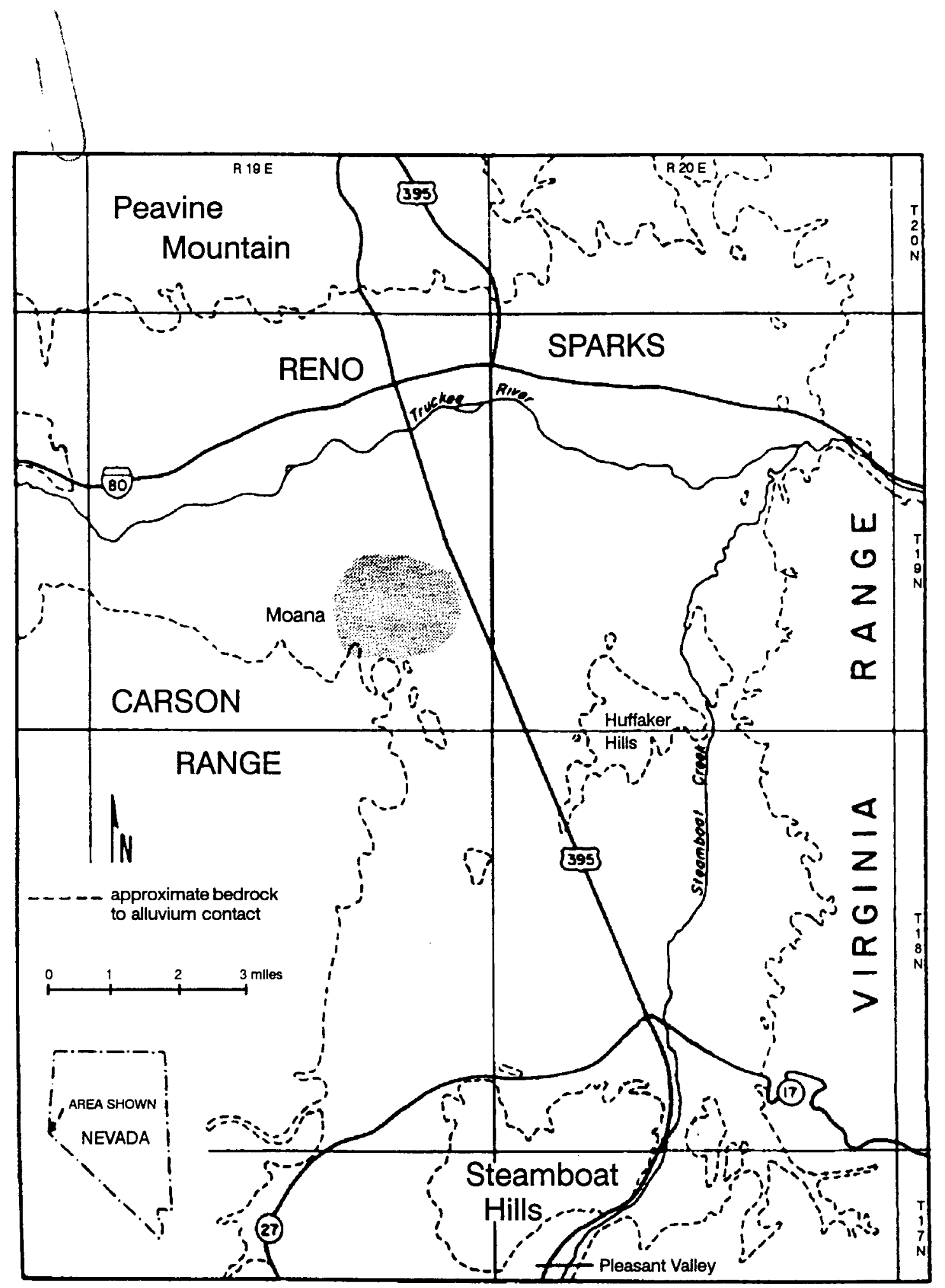

FIGURE 1. Location Map Showing the Moana Geothermal Area in the Truckee Meadows (after Bateman and Scheibach, 1975). 
The Moana area abuts the eastern flank of the Carson Range as shown in Figure 1. Structural relief in the resource area is believed to be associated with the uplift of this range. Uplift of the northern Carson Range is by flexure, possibly related to concealed Tertiary intrusions, and forms a partial dome (Thompson and White, 1964). The domical structure is broken by many normal faults, most of which are antithetic; that is, the displacement is down on the mountain side of the faults. The structural relief produced by antithetic faulting therefore subtracts from the uplift.

Most faults of the Moana area display Pleistocene movement, but very few fault planes offset known Holocene deposits (Bingler, 1975). Two fault trends were recognized by Flynn and Ghusn (1984), one trending north $20^{\circ}$ east and the other north $10^{\circ}$ west. The fault system in the Moana area is believed to be one of the principal conduits for thermal fluid migration (Bateman and Scheibach, 1975).

Gravity surveys have established the existence of buried structure in the Moana area (Scheibach, 1975; Flynn and Ghusn, 1984). A gravity high curves from west to north through the center of the Moana resource area. The gravity high forms a ridge that roughly corresponds to outcrops and shallow occurrences of bedrock (Kate Peak Formation). Surface expression of faulting parallels the ridge and may be related to the structure (Scheibach, 1975).

The geology of the area has been mapped by Bonham and Rogers (1983). Three major rock units in the Moana area have been identified from outcrops and well log data (Flynn and Ghusn, 1984). The rock units are, from oldest to youngest, Pliocene Kate Peak Formation, Pliocene Sandstone of Hunter Creek, and Quaternary alluvium. A geologic map of the Moana area is presented in Figure 2.

The Kate Peak Formation dates from the lower Pliocene and consists of a thick sequence of flows, flow breccias, tuffs, tuff-breccias, volcanic sandstone and conglomerate, and shallow intrusive bodies (Bonham, 1969). The volcanic rocks range from andesite to rhyolite in composition, with dacite being the most common rock type. Under much of the Moana area, the uppermost member of the Kate Peak Formation consists of a hydrothermally altered rhyodacite vitrophyre (Flynn and Ghusn, 1984). This altered vitrophyre, commonly referred to as "blue clay", is composed almost entirely of smectite, a structurally disordered clay (Flynn and Ghusn, 1984). Drillers' logs report a strong correlation between the blue clay and the occurrence of thermal waters.

Overlying and interfingering with the Kate Peak Formation is the Sandstone of Hunter Creek, also of Pliocene age. The Sandstone of Hunter Creek is identified as the Truckee Formation by earlier authors (Cohen and Loeltz, 1964; Thompson and White, 1964; Scheibach, 1975). This report will refer to the formation as the Sandstone of Hunter Creek as proposed by Bingler (1975) to be consistent with the more recent work of Flynn and Ghusn (1984). The Sandstone of Hunter Creek is described by Bin- 
gler (1975) as intercalated siltstone and fine sandstone, and moderately well sorted, texturally mature medium pebble to small cobble gravelly sand. The formation can be subdivided into three members: a lower greywacke member, a thick medial sequence of diatomaceous siltstone, and an upper member of sandstone (Flynn and Ghusn, 1984). The lower member is very gravelly with the mean size of clasts increasing toward the basal contact with volcanic rock. Lowermost beds include abundant volcanic detritus, thin tuff beds and mudflows (Bingler, 1975). The medial member is composed almost entirely of diatomite and diatomaceous siltstones and sandstones. It may be as much as $1,500 \mathrm{ft}$ thick in the Moana area. The upper member is a complex sequence which grades upward from diatomaceous sandstone and volcanic arenite to well sorted dune deposits (Ghusn, 1982).

Quaternary deposits in the Moana area unconformably overlie the Tertiary sedimentary and volcanic formations. These deposits were classified by Bingler (1975) into three general groups: 1) Pleistocene, alluvial fan deposits, consisting of poorly sorted sands and gravels; 2) Illinoian and Wisconsinan outwash deposits composed of well rounded gravels and sands; and 3) Holocene, fluvial and alluvial deposits of fine sands, silts, and clays derived from reworking of the earlier alluvial fan and outwash deposits.

\section{GEOTHERMAL AQUIFER}

Bateman and Scheibach (1975) proposed a fault-charged model for the geothermal area. The model can be described as follows: 1) cool water originating in the Carson Range to the west percolates downward along permeable zones, probably faults or joints; 2) a high regional heat flow gradient of $52^{\circ} \mathrm{C} / \mathrm{km}$ combined with deep circulation heats the water; 3 ) the resultant decrease in density causes the thermal water to rise along normal faults in the Moana resource area; and 4) the thermal water then diffuses laterally in permeable horizons away from the faults. A schematic of a lateral leakage model, which is similar to the conceptual model of Bateman and Sheibach, is presented in Figure 3. Temperature data from drillers' logs support this model. The highest reported temperatures in the geothermal aquifer are in the vicinity of known fault locations.

The geothermal aquifer occurs under leaky, confined conditions primarily within the Kate Peak Formation. Thermal water, usually of lower temperature, is also present in the sedimentary deposits above the Kate Peak. Drillers report thermal water at depths of $100 \mathrm{ft}$ or less near the center of the resource area. This shallow occurrence of the geothermal aquifer corresponds to the presence of the Kate Peak Formation in the shallow subsurface. Well logs indicate that the formations comprising the geothermal aquifer extend to at least 3,000 ft below land surface (Glenn McCormack, Peppermill Engineer, Personal Communication, 1989). Within the geothermal aquifer, thermal water moves preferentially through jointed and fractured units, and intraflow breccias 


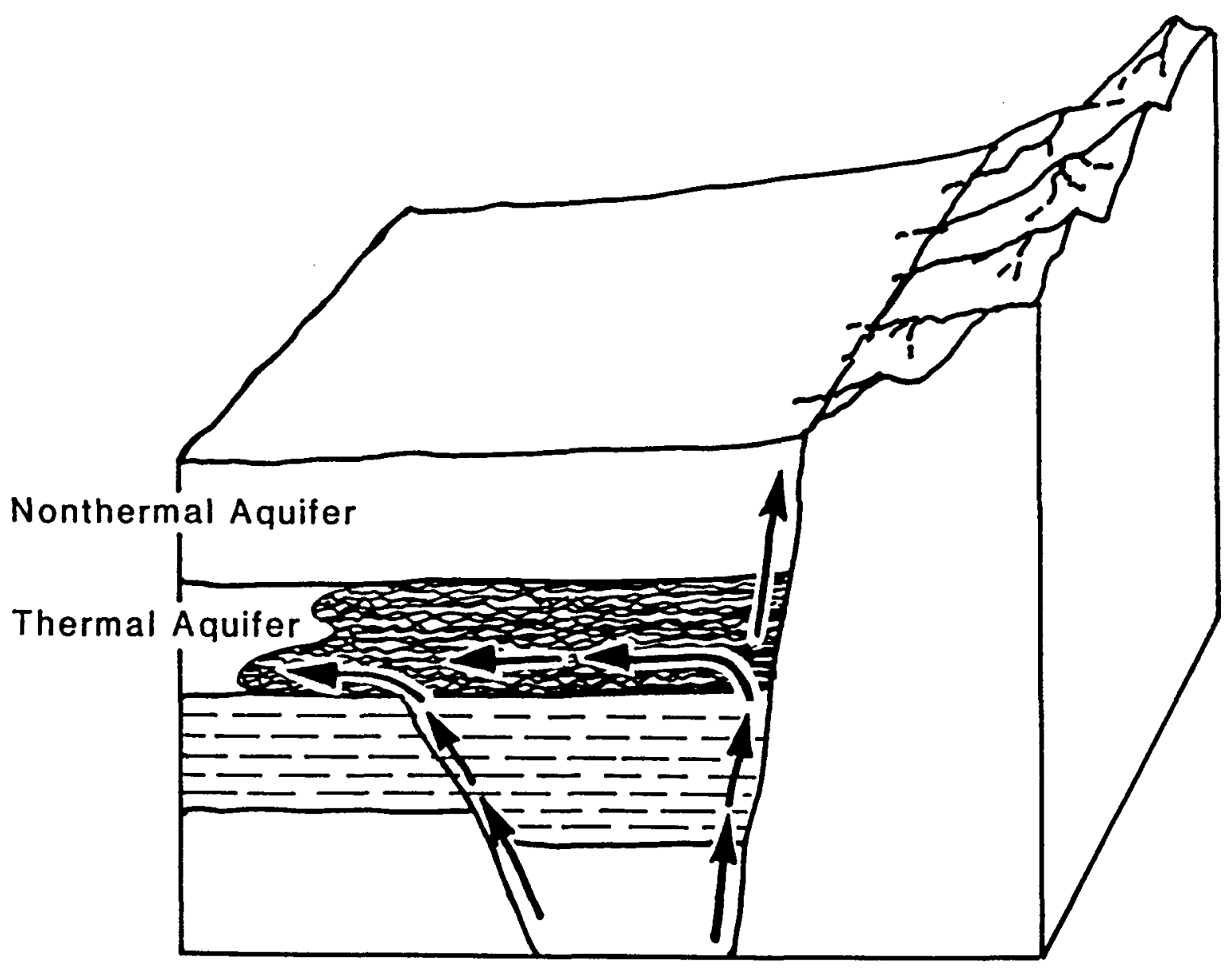

FIGURE 3. Lateral Leakage Model for Low and Intermediate Temperature Hydrothermal Resources (modified from Figure 3.12A in Wright and Culver, 1989).

of the Kate Peak Formation and in sand and gravel beds of the sedimentary formations. Flynn and Ghusn (1984) also identified the contact between the Kate Peak and the Sandstone of the Hunter Creek as an important conduit for thermal water migration. Permeable units in the geothermal aquifer range in thickness from less than a foot to tens of feet and display high areal variability. Low permeability units in the Moana area effectively confine the geothermal aquifer so that artesian conditions are present in most of the resource area. Confining units include, but are not limited to, the altered vitrophyre or "blue clay" of the Kate Peak Formation, the siltstones of the Sandstone of Hunter Creek, and clay layers in the Quaternary alluvium (Bateman and Scheibach, 1975).

Water level data compiled by Flynn and Ghusn (1984) show the piezometric surface of the thermal water dips towards the northeast and east, as does the general to- 
pography. The piezometric surface as developed by Flynn and Ghusn is given in Figure 4. Thermal water is believed to rise along the faults in the western and central portions of the resource area and subsequently flow to the northeast and east. Temperature data support this hypothesis. The highest temperatures, $90^{\circ} \mathrm{C}$ to $98^{\circ} \mathrm{C}$, are found in the western and central portions of the resource area in close proximity to faults. Geothermal aquifer temperatures decrease in the eastern portion of the resource area with maximum reported temperatures of $70^{\circ} \mathrm{C}$ or less.

\section{Aquifer Testing}

Information on the hydraulic properties of the geothermal aquifer in the Moana area is very limited. Most researchers simply describe the hydraulic conductivity of the aquifer as "low", without quantifying their statements. Aquifer testing has been restricted to a few large commercial heating wells and a group of tests performed by the Geo-Heat Center of the OIT.

Aquifer pumping tests were performed on wells associated with the two district heating systems, Warren Estates and Sierra Geothermal Incorporated. William E. Nork, Inc. performed a constant rate discharge test on the injection well of Sierra Geothermal Incorporated. This well is $895 \mathrm{ft}$ deep, is perforated from 739 to $889 \mathrm{ft}$, and is completed in the Kate Peak Formation. The well was pumped for 24 hours at a discharge rate of 200 gallons/minute. Transmissivity was calculated using both time-drawdown and residual-drawdown data. The values were $168 \mathrm{ft}^{2} /$ day and $337 \mathrm{ft}^{2} /$ day, respectively. Dividing the transmissivity values by the length of the perforated interval yields a hydraulic conductivity range of 1.12 to $2.25 \mathrm{ft} /$ day.

REMCO (1985) performed a pump test on the Warren Estates production well, WE-2. This well is $685 \mathrm{ft}$ deep, has a perforated interval of approximately $80 \mathrm{ft}$, and is completed in an intraflow breccia of the Kate Peak Formation. The well was pumped for 27 hours at a constant flow rate of 990 gallons/minute. Water levels were monitored in both the pumping well, WE-2, and a nearby well, WE-1. Analysis of the pumping test data yielded a transmissivity of $3,040 \mathrm{ft}^{2} /$ day and a storage coefficient of 0.00105 . Dividing the transmissivity by the perforated interval length produces a hydraulic conductivity value of $38 \mathrm{ft} /$ day.

The Geo-Heat Center performed Hvorslev tests on six domestic geothermal wells in the Moana area (Allis, 1981). Well depths ranged from $131 \mathrm{ft}$ to $300 \mathrm{ft}$. Five of the six wells were completed in the "blue clay" of the Kate Peak Formation and the remaining well was completed in Quaternary alluvium. Hydraulic conductivity ranged from 0.11 $\mathrm{ft} /$ day to $19.88 \mathrm{ft} /$ day for the wells in the Kate Peak Formation. The well completed in the Quaternary alluvium had a hydraulic conductivity of $4.83 \mathrm{ft} /$ day.

The hydraulic information, although limited, illustrates the heterogeneity of the geothermal aquifer. Hydraulic conductivity values from the eight locations vary by 


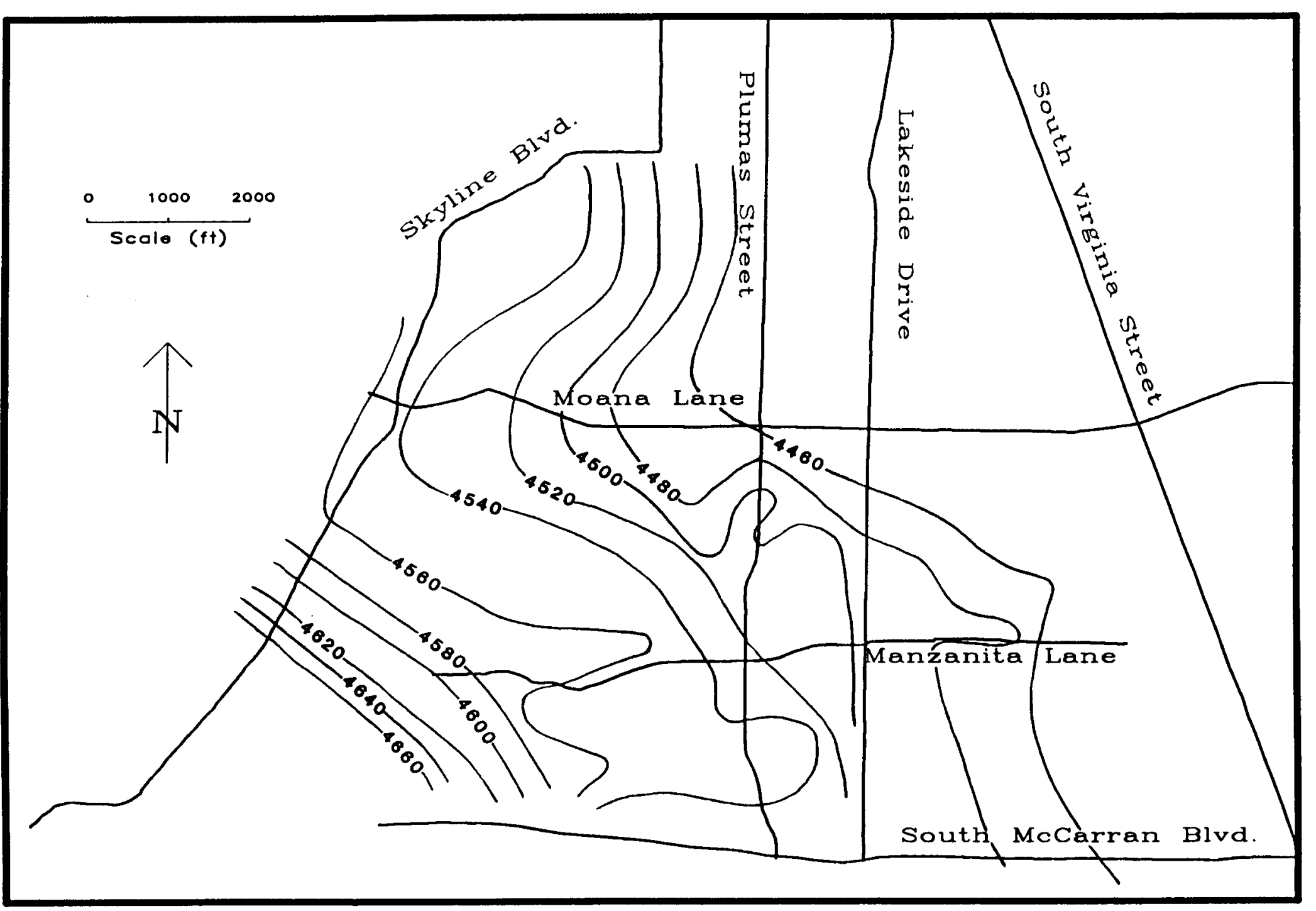

FIGURE 4. Piezometer Surface Elevations of Thermal Fluids in Moana (from Flynn and Ghusn, 1984). 
three orders of magnitude. The one storage coefficient calculated for the geothermal aquifer, 0.00105 , is within the range expected for a confined aquifer.

In late summer 1988, as part of this project, an injection test was planned to obtain information on the hydraulic properties of the geothermal aquifer. The source of water was going to be from a nearby fire hydrant, however, due to the drought conditions, the fire marshall would not allow use of the water, and the test was cancelled.

\section{TEMPERATURE DATA}

Temperature data provide important insight into fluid migration and heat transfer processes within the geothermal system. Historical temperature data for the Moana area were obtained from three sources: 1) drillers' logs; 2) Ghusn (1982); and 3) Flynn and Ghusn (1984). Drillers most often used a maximum reading thermometer to gather temperature data. Flynn and Ghusn (1984) employed a cable reel digital thermometer in their work. Typical temperature profiles from the Moana area found by Flynn and Ghusn are shown in Figures 5 and 6 for the monitoring wells at Horseman's Park and Manzanita Park, respectively.

A number of problems exist with the historical temperature database which need to be discussed prior to interpretation of the data. Prucha (1987) states that obtaining an accurate formation temperature is strongly dependent on when the the measurement is taken. He sites the circulation of drilling fluids, intraborehole circulation from hydraulic potentials and buoyancy effects, and pumping of geothermal fluids as potential sources of error in temperature data. Although his research was on the Klamath Falls geothermal system, these sources of error are also of concern in the Moana area. Temperature data obtained after installation of a heating system are also believed to be biased. Approximately 90 percent of the geothermal wells in the Moana area use some type of downhole heat exchanger which removes heat from the fluids in the well. Therefore, temperature data from wells with downhole heat exchangers will be artificially low. This is thought to be a problem with some of the temperature data from Ghusn (1982) and Flynn and Ghusn (1984).

The previously discussed sources of error suggest that temperature profiles measured during the drilling process may provide the best available data on formation temperatures. The majority of wells in the Moana area were drilled using cable tool rigs which do not use drilling fluids. Temperature bias from the circulation of drilling fluids is not a problem for wells drilled in this manner. Generally, temperature measurements were obtained prior to well completion and installation of the heat exchange system. For these reasons, the measurements are believed to be close to the actual formation temperatures.

Several different heat flow phenomena can be identified from the temperature profiles shown in Figures 5 and 6. Sass and Sammel (1976) classified temperature pro- 


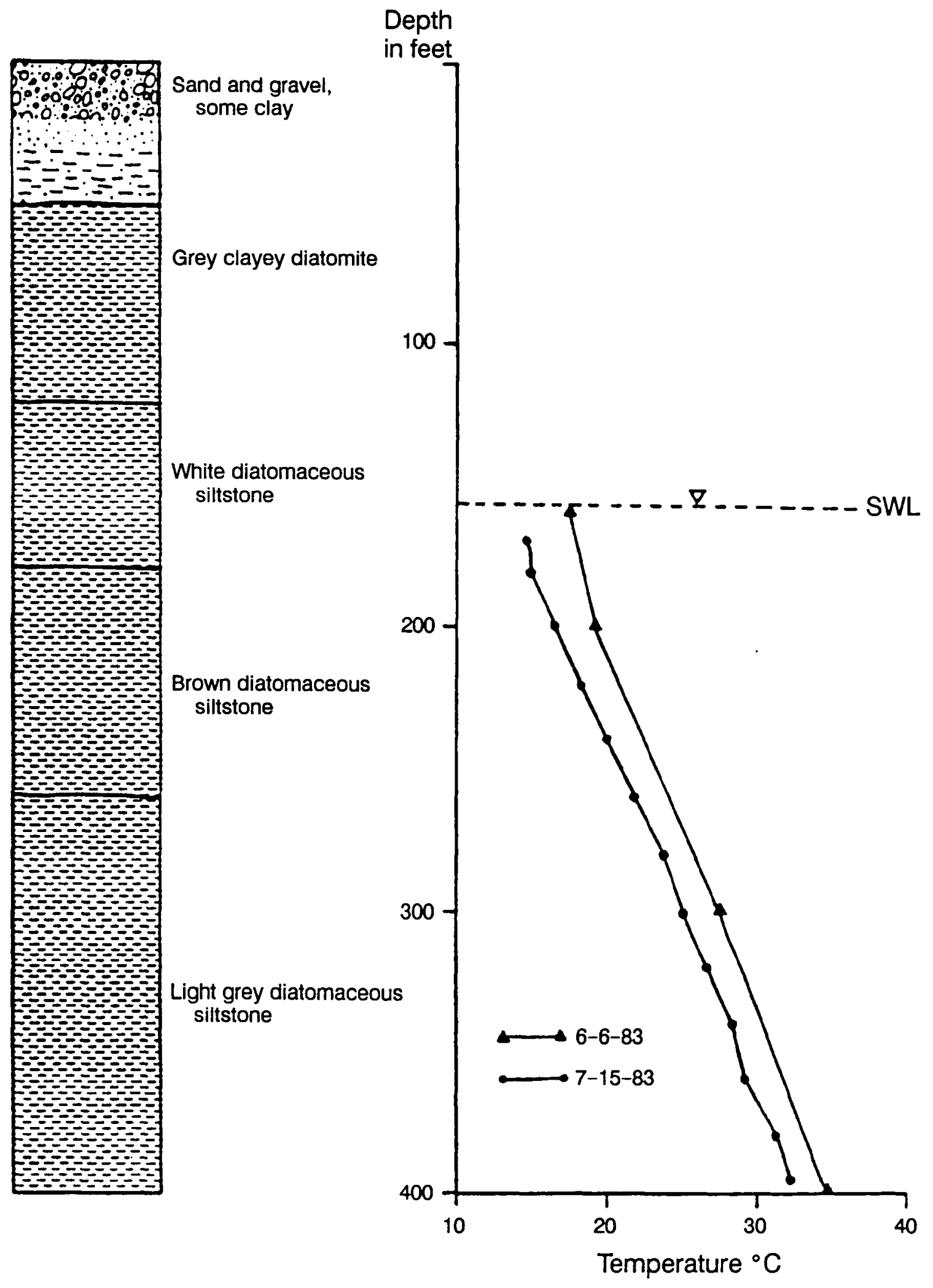

FIGURE 5. Lithologic Log and Temperature-Depth Profile for the Monitoring Well at Horseman's Park (from Flynn and Ghusn, 1984). 


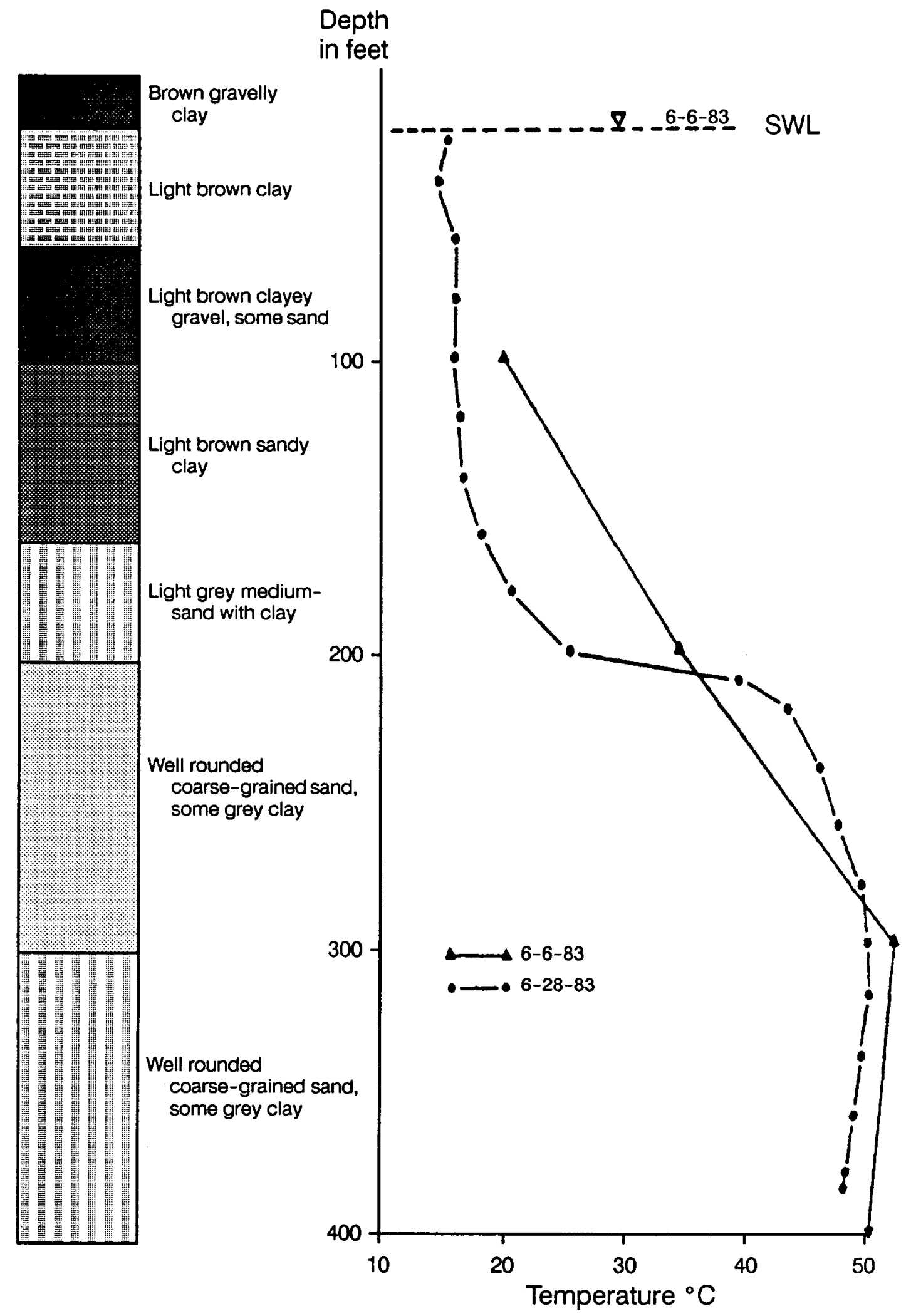

FIGURE 6. Lithologic Log and Temperature-Depth Profile for the Monitoring Well at Manzanita Park (from Flynn and Ghusn, 1984). 
files in the Basin and Range physiographic province into four different types: 1) nearly isothermal temperature profiles in the range of $10^{\circ}-12^{\circ} \mathrm{C}$, which indicate hydrologic recharge; 2) quasi-conductive profiles, which extrapolate upward to surface temperatures in the range of $10^{\circ}-13^{\circ} \mathrm{C} ; 3$ ) convex upward profiles with elevated temperatures, which represent discharging parts of the hydrothermal system; and 4) profiles exhibiting various types of curvature, indicating a combination of upward and downward flow. Temperature profiles from the Moana area exhibit mostly quasi-conductive and convex upward behavior. Irregularities or spikes in the temperature profiles are thought to be caused by preferential movement of thermal water in high permeability horizons within the geothermal aquifer.

\section{FLUID CHEMISTRY}

Fluid samples collected in the Moana area can be broadly classified into two different types: 1) nonthermal, bicarbonate $\left(\mathrm{HCO}_{3}\right)$ dominated water; and 2) thermal, sulfate $\left(\mathrm{SO}_{4}\right)$ dominated water. Typical analyses for each water type are given in Table 1 . Nonthermal waters are generally more dilute than thermal waters, with large differ-

TABLE 1. TYPICAL THERMAL AND NONTHERMAL WATERS IN THE MOANA GEOTHERMAL RESOURCE AREA.

\begin{tabular}{|c|c|c|}
\hline $\begin{array}{l}\text { Type: } \\
\text { Location: } \\
\text { Temperature }\left({ }^{\circ} \mathrm{C}\right) \text { : }\end{array}$ & $\begin{array}{l}\text { Thermal Well }{ }^{1} \\
\text { 19N 19E 26ADAB } \\
85^{\circ}\end{array}$ & $\begin{array}{l}\text { Nonthermal Well } \\
19 \mathrm{~N} 19 \mathrm{E} 22 \mathrm{AC} \\
23^{\circ}\end{array}$ \\
\hline $\begin{array}{l}\mathrm{HCO}_{3}(\mathrm{mg} / \mathrm{l}) \\
\mathrm{CO}_{3}(\mathrm{mg} / \mathrm{l}) \\
\mathrm{Cl}(\mathrm{mg} / \mathrm{l}) \\
\mathrm{SO}_{4}(\mathrm{mg} / \mathrm{l}) \\
\mathrm{NO}_{3}(\mathrm{mg} / \mathrm{l}) \\
\mathrm{F}(\mathrm{mg} / \mathrm{l}) \\
\mathrm{B}(\mathrm{mg} / \mathrm{l})\end{array}$ & $\begin{array}{c}86.9 \\
- \\
49.2 \\
479.0 \\
0.22 \\
4.83 \\
2.2 \\
\end{array}$ & $\begin{array}{c}156.0 \\
- \\
22.0 \\
48.0 \\
- \\
0.4 \\
-\end{array}$ \\
\hline $\begin{array}{l}\mathrm{Na}(\mathrm{mg} / \mathrm{l}) \\
\mathrm{K}(\mathrm{mg} / \mathrm{l}) \\
\mathrm{CA}(\mathrm{mg} / \mathrm{l}) \\
\mathrm{Mg}(\mathrm{mg} / \mathrm{l}) \\
\mathrm{As}(\mathrm{mg} / \mathrm{l}) \\
\mathrm{Li}(\mathrm{mg} / \mathrm{l})\end{array}$ & $\begin{array}{c}265.0 \\
8.42 \\
27.4 \\
0.17 \\
0.11 \\
0.24\end{array}$ & $\begin{array}{r}23.0 \\
2.6 \\
51.0 \\
7.1 \\
\overline{0} \\
0.4\end{array}$ \\
\hline $\begin{array}{l}\mathrm{SiO}_{2}(\mathrm{mg} / \mathrm{l}) \\
\mathrm{TDS}(\mathrm{mg} / \mathrm{l}) \\
\mathrm{EC}(\mu \mathrm{mhos} / \mathrm{cm}) \\
\mathrm{pH}\end{array}$ & $\begin{array}{r}118 \\
1,042 \\
1,350 \\
8.05\end{array}$ & $\begin{array}{r}41 \\
351 \\
436 \\
8.1\end{array}$ \\
\hline
\end{tabular}

1 from Scheibach, 1975

2 from Cohen and Loeltz, 1964

- (data not available) 
ences in the concentration of several ionic constituents, particularly sulfate $\left(\mathrm{SO}_{4}\right)$, bicarbonate $\left(\mathrm{HCO}_{3}\right)$, sodium $(\mathrm{Na})$, and magnesium $(\mathrm{Mg})$. Mixing between nonthermal and thermal waters has been identified and can cause significant variation in the chemical composition of each water type (Scheibach, 1975). The analyses shown in Table 1 are thought to be end member examples of each water, showing little or no mixing.

\section{Nonthermal Water}

Major chemical constituents in nonthermal waters of the Moana area include the anions bicarbonate $\left(\mathrm{HCO}_{3}\right)$, chloride $(\mathrm{Cl})$, sulfate $\left(\mathrm{SO}_{4}\right)$, the cations sodium $(\mathrm{Na})$, potassium $(\mathrm{K})$, calcium $(\mathrm{Ca})$, magnesium $(\mathrm{Mg})$, and silica $\left(\mathrm{SiO}_{2}\right)$. The fluid chemistry of this water type is largely dependent on composition of the recharge water and groundwater-rock interaction in the sedimentary formations of the area.

Recharge to the shallow, nonthermal aquifer is primarily from irrigation water. Unconsumed irrigation water applied to lawns and pasture as well as leakage from irrigation ditches that traverse the area contribute significant recharge to the aquifer (Cohen and Loeltz, 1964). The source of irrigation water is the Truckee River. Truckee River water is relatively dilute with a total dissolved solids concentration of less than 100 milligrams per liter (mg/l) in most years (Chesley et al., 1990). Major chemical constituents are, in order of decreasing concentration, $\mathrm{HCO}_{3}, \mathrm{SiO}_{2}, \mathrm{Ca}, \mathrm{Na}, \mathrm{Mg}, \mathrm{Cl}, \mathrm{SO}_{4}$, and $\mathrm{K}$. The dominant ionic species in Truckee River water is $\mathrm{HCO}_{3}$, which accounts for more than half the total dissolved solids concentration. Precipitation falling on the Moana area may contribute minor amounts of recharge to the nonthermal aquifer. Because of the dilute nature of precipitation, chemical contributions to the aquifer from this source are assumed to be negligible.

The balance of dissolved chemical constituents result from groundwater-rock interaction. Nonthermal waters in the Moana area occur primarily in sedimentary formations. Minerals associated with weathering by-products of igneous rocks are found in these formations and provide an abundant source of reactants.

Sodium is relatively abundant in nonthermal waters of the Moana area. It is derived principally from chemical weathering of sodium-rich plagioclase feldspars in the igneous rocks of the area and to a lesser extent from ferromagnesium minerals in these rocks (Cohen and Loeltz, 1964). Calcium and magnesium ions in solution may be exchanged for sodium in sodium-containing minerals. Several authors believe this mechanism, cation exchange, to be partially responsible for increasing the sodium concentration in waters of the area (Flynn and Ghusn, 1984; Cohen and Loeltz, 1964).

Potassium concentrations are low in both the nonthermal waters and rocks of the area. Levels are generally less than those of the other major cations: sodium, calcium and magnesium. 
Calcium and magnesium occur in most of the volcanic rocks of the area and the sediments derived from these rocks (Thompson and White, 1964). Plagioclase feldspars in the andesites of the Kate Peak Formation contain varying amounts of calcium. Calcium and magnesium are also present in the pyroxene and amphibole group minerals in these rocks. Weathering of these minerals produces many calcium and magnesium compounds that are moderately to highly soluble in water (Cohen and Loeltz, 1964).

Bicarbonate is the most abundant anion in nonthermal waters of the area. Its concentration is a function of dissolved carbon dioxide in the water, chemical weathering of silicate minerals, $\mathrm{pH}$, temperature, and concentration of other ionic species. Given the abundance of silicate minerals, such as feldspars and clays, and the supply of carbon dioxide-charged water infiltrating from the soil zone, it is apparent why bicarbonate ions are a major constituent in nonthermal waters of the area.

Sulfate in waters of the area is derived principally from hydrothermally altered volcanic rocks at the margins of the valley (Cohen, 1962). Hydrothermal alteration of these rocks has produced pyrite and other metallic sulfides. Oxidation and hydration of the sulfides result in the formation of sulfurous and sulfuric acid, which bleaches the rocks. The bleached rocks are rich in sulfate compounds and consist predominantly of clay, opal, and some quartz (Cohen, 1962). Streams draining areas of bleached rock and wells downgradient from these areas can have extremely high sulfate contents. Cohen and Loeltz (1964) report sulfate values of almost $2,000 \mathrm{mg} / \mathrm{l}$ in nonthermal wells west of the resource area.

Minerals containing soluble chloride compounds are rare in the rocks of the area. Potential sources of chloride in nonthermal waters of the area include: 1) mixing with thermal waters; 2) rock leaching of volcanic detritus; and 3) application of road salts during the winter.

\section{Thermal Water}

Moana thermal waters contain, in order of decreasing concentration, sulfate $\left(\mathrm{SO}_{4}\right)$, sodium $(\mathrm{Na})$, silica $\left(\mathrm{SiO}_{2}\right)$, bicarbonate $\left(\mathrm{HCO}_{3}\right)$, chloride $(\mathrm{Cl})$, calcium $(\mathrm{Ca})$, potassium $(\mathrm{K})$, as well as minor amounts of fluoride $(\mathrm{F})$, magnesium $(\mathrm{Mg})$, boron $(\mathrm{B})$, lithium ( $\mathrm{Li}$ ), and arsenic (As). Constituents of the thermal waters show limited ranges of concentration with most variation in $\mathrm{SO}_{4}, \mathrm{Na}$, and $\mathrm{HCO}_{3}$. The fluid chemistry of thermal water is primarily a function of groundwater-rock interaction. Ellis and Mahon (1964) have shown that appreciable quantities of minor elements in rocks, such as $\mathrm{Cl}$, $\mathrm{B}, \mathrm{F}$ and $\mathrm{SO}_{4}$, can be leached from volcanic rocks by water.

Reactions are similar to those described in the nonthermal water section. The higher concentrations of certain ionic species result from the longer flow path, longer 
residence time, and the elevated temperatures and pressures experienced by the thermal waters.

\section{Mixing}

Scheibach (1975) was the first to suggest natural mixing within the geothermal aquifer between thermal and nonthermal waters. The relationship between temperature and concentration of certain ionic species supports the mixing hypothesis. The different chemical makeup of the thermal and nonthermal waters of the area can be used to identify the degree of mixing in the geothermal aquifer. Empirical relationships can be developed for temperature and ionic concentration and those relationships will be discussed in the section on groundwater chemistry.

\section{DIRECT USE}

The Moana geothermal area supports the largest direct use application of a low to moderate temperature $\left(<150^{\circ} \mathrm{C}\right)$ geothermal resource in the State of Nevada (Flynn and Ghusn, 1984). Residential and commercial space heating are the dominant resource applications. More than 160 wells extract heat and hot water from the geothermal aquifer in an area of less than 5 square miles. A map of the study area showing all the geothermal well locations is given in Figure 7.

The majority of geothermal wells are used for residential heating. Generally, each residence has its own well. Well construction is similar to ordinary water wells with a 6 or 8-inch casing the entire depth of the well. The well casing is commonly perforated at the bottom where the maximum temperatures are generally found (Flynn and Ghusn, 1984). The upper $50 \mathrm{ft}$ of casing is usually cemented in place as a sanitary seal and to prevent leakage of nonthermal water into the geothermal aquifer. Most residential wells use a simple loop, downhole, heat exchanger. The heat exchanger consists of two strings of pipe connected by a reverse bend at the bottom. City water is circulated through the loop and extracts heat from the geothermal water in the well. Over 90 percent of the residences intermittently pump off geothermal water to maintain high temperatures in the wells. The pumped geothermal water is usually discharged to the storm drain or sewer.

Several residential wells in the Moana resource area are extractive and geothermal water is pumped directly into the home heating system. Residential extractive wells are generally found in low temperature areas where heat exchangers would make the resource uneconomic. Resource temperatures above $50^{\circ} \mathrm{C}$ are considered to be economic.

Commercial users of the geothermal resource include the Peppermill Hotel-Casino, Virginia Lake Townhouses, and two district heating systems, Warren Estates and 


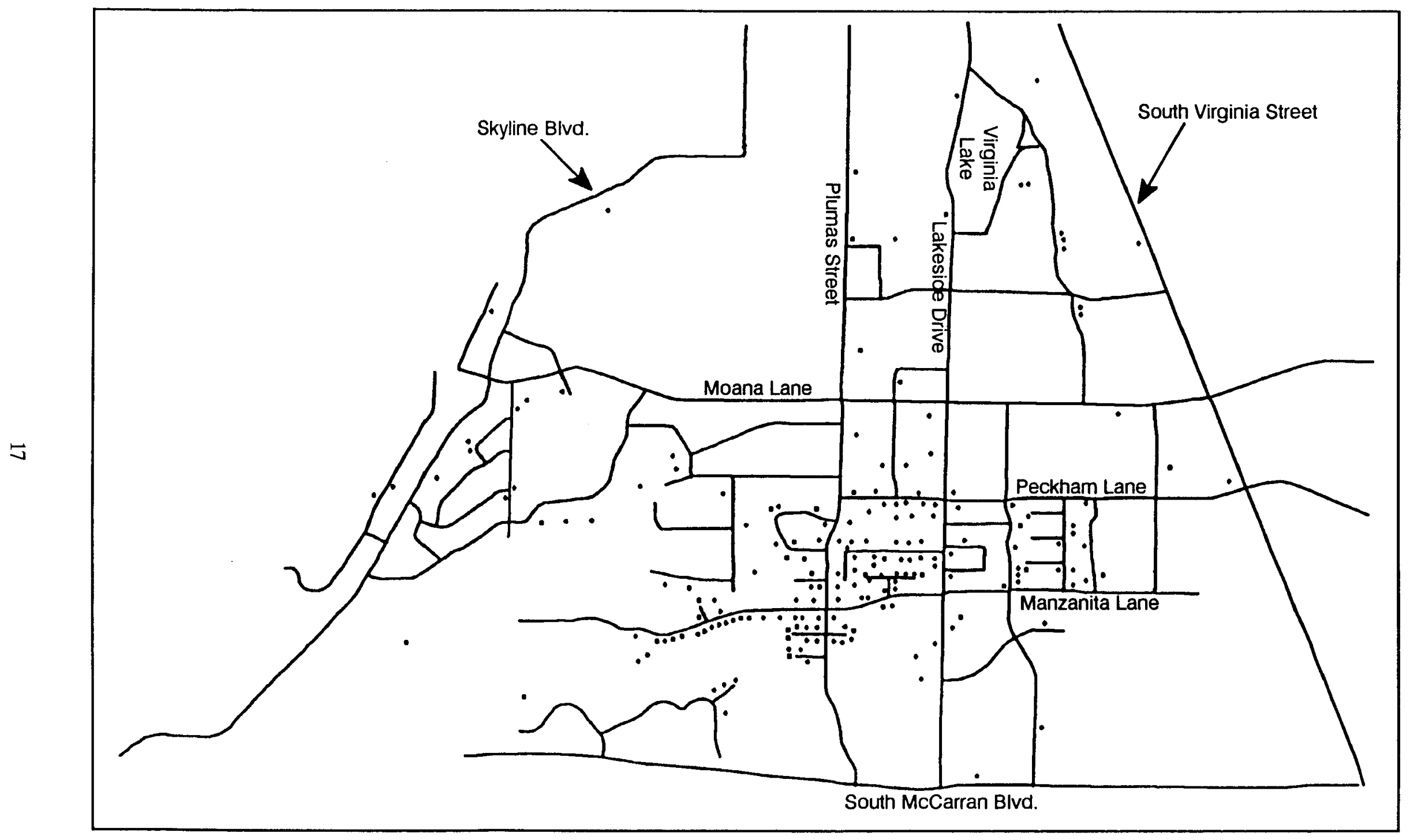

FIGURE 7. Location of Geothermal Wells in the Moana Geothermal Area (dot indicates a geothermal well location). 
Sierra Geothermal Incorporated. All commercial users are extractive because of the large heat requirements. Geothermal water is pumped through surface heat exchangers and subsequently injected downgradient from the production wells. 


\section{DATA COLLECTION}

The second phase of this project was to collect field data. The main objectives of this phase were to: 1) monitor transient response of the geothermal aquifer; and 2) fill in gaps in the historical database. Thermal, water level, and hydrochemical data were collected from various locations in the Moana resource area for one heating cycle of 13 months. A preliminary sampling plan was developed with the goal of collecting information from the most heavily impacted portions of the geothermal area and along the boundaries where possible. The geothermal wells are generally used for private home heating use, so the homeowners had to be contacted and permission gained to monitor their wells for the 13-month period. Collection of field data at various wells started in October 1988.

\section{THERMAL DATA}

Temperature gradient measurements were performed in over 50 geothermal wells during the course of the investigation. Geothermal wells were selected for inclusion in the field investigation on the basis of three factors. First, a series of wells was chosen to help assess the boundary conditions at various points in the geothermal area. Second, wells in areas of high areal temperature gradients were included to help identify conditions influencing the thermal and hydraulic properties of the resource area. The final criteria, and maybe most important, was well access. Two facets of well access were considered for inclusion in the field investigation: 1 ) owner cooperation allowing access to the well; and 2) well construction that facilitated measurement of temperature data.

A group of 28 geothermal wells was selected from the locations visited for monthly monitoring of temperature gradient and water level data. Two wells in the group were eventually dropped from the study at the owners request. Monthly temperature gradient and water level data were collected for 26 geothermal wells during the 13-month period between January 1989 and February 1990. Five types of wells were included in the study group. The types of wells were: 1) domestic well with downhole heat exchanger and pump; 2) domestic well with downhole heat exchanger and no pump; 3) extractive well, pump and no heat exchanger; 4) unused domestic or commercial well; and 5) monitor well, no pump, no heat exchanger. Differences in the thermal response of each well type are largely a function of well construction. The location and construction details of each well in the study group are listed in Appendix I and locations are shown in Figure 8. The numbering of the wells corresponds to the numbering found in Appendix I.

Examples of heating and nonheating temperature gradient profiles are presented in the following discussion of the thermal data. This provides a comparison of well response and, to a certain extent, aquifer response to periods of high and low thermal load. The maximum heating period was considered to be from December to March and includes the period of maximum heat extraction from the geothermal aquifer. The nonheating period was considered to be from June to September. For most wells, data from 


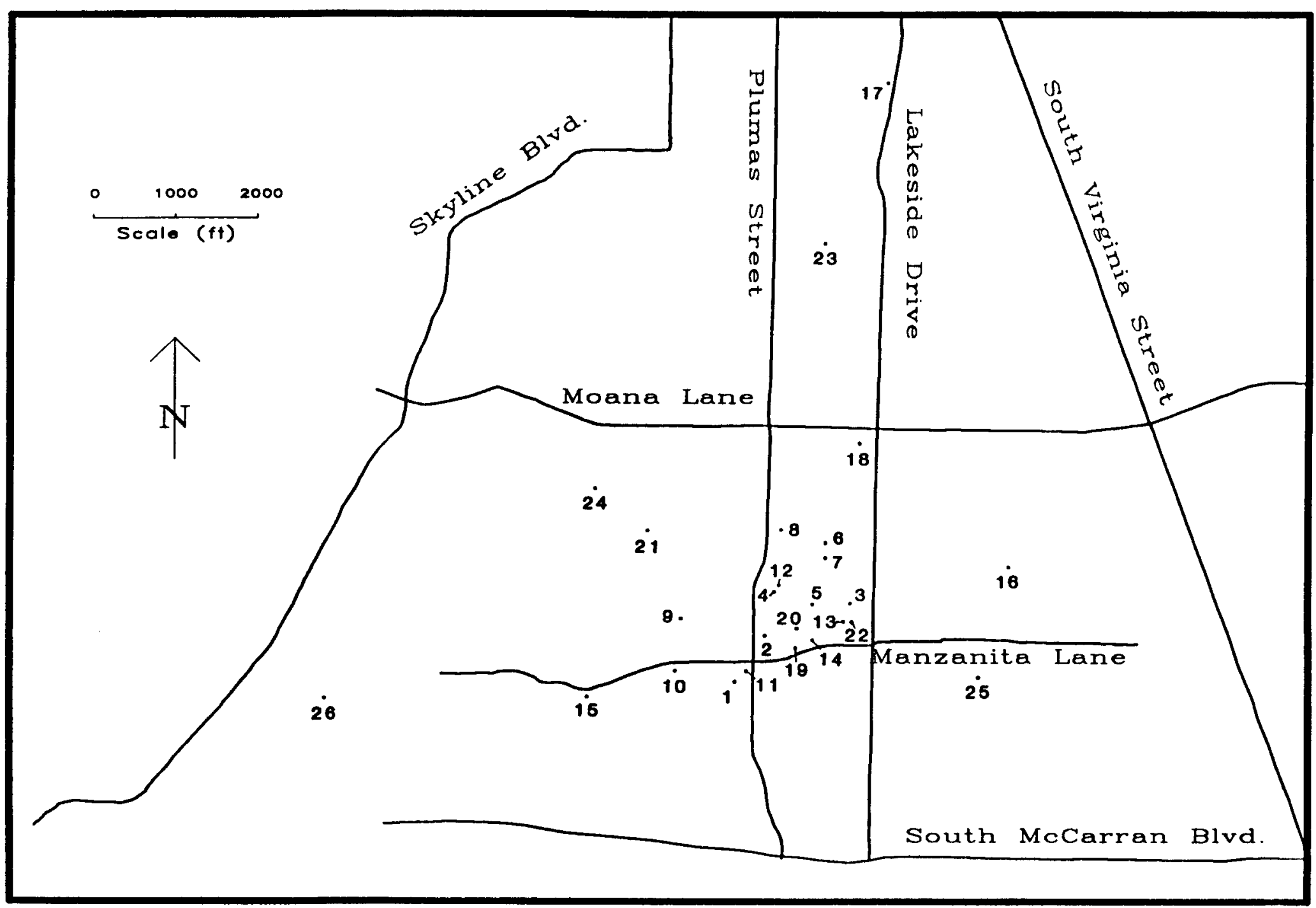

FIGURE 8. Location of the 26 Geothermal Wells Included in the Study Group from which Water Level and Temperature Data were Collected. 
the months of January and August are presented for comparison. However, in some cases, poor quality data were collected during those months and alternate heating and/ or nonheating temperature gradient profiles are presented for comparison. Heating and nonheating temperature gradient profiles for all 26 geothermal wells are given in Appendix II.

Domestic wells with downhole heat exchangers and a pump to purge cooled geothermal fluids represent the most common type of well in the Moana resource area. Ten wells of this type were included in the field investigation and make up the largest portion of the study group. The pumps that purge cooled geothermal fluids from wells are usually controlled by thermostat. When the temperature of the water entering the heating system drops below a certain point, the pump turns on and draws hot water into the well bore. When the temperature of the water in the heating system rises, the pump turns off. Temperature data collected from this well type are strongly dependent on the pump cycle and the thermal load of the house.

Examples of heating and nonheating temperature gradient profiles for wells with downhole heat exchangers and pumps are shown in Figures 9, 10 and 11. Generally, the nonheating temperature gradient profile has higher temperatures (Figures 9 and 10 for Well 10 and Well 6, respectively). The higher thermal load placed on the well during the heating season has the effect of lowering temperatures in the well. However, several wells had higher temperatures at the bottom of the well, in the perforated interval, during the heating season than during the nonheating season as observed in Figure 11 for Well 1. This is thought to result from recent pumping of the well drawing in fresh geothermal water into the well.

Five wells in the study group were domestic wells with downhole heat exchangers and no pump. This type of well is generally restricted to areas of high temperature and/ or high permeability. Examples of heating and nonheating temperature profiles are shown in Figures 12 and 13. Thermal behavior in this type of well is dependent on the thermal load of the house. When heating loads are high during cold weather, temperatures are depressed in the well bore. In the warmer months when heating loads are small, temperatures are higher in the well bore, as strongly indicated in Figure 12 for Well 14, and to a lesser degree in Figure 13 for Well 15.

Temperature data from both types of wells with downhole heat exchangers are thought to be artificially low. Generally, the heat exchangers provide hot water for domestic use throughout the year. Therefore, even during the summer months when space heating requirements are nonexistent, a small thermal load is placed on the well by the need for domestic hot water.

Three wells in the study group were extractive types, with the geothermal fluids pumped directly into the heating system of the structure. Extractive wells are found most often in portions of the resource area where fluid temperatures are low, which 


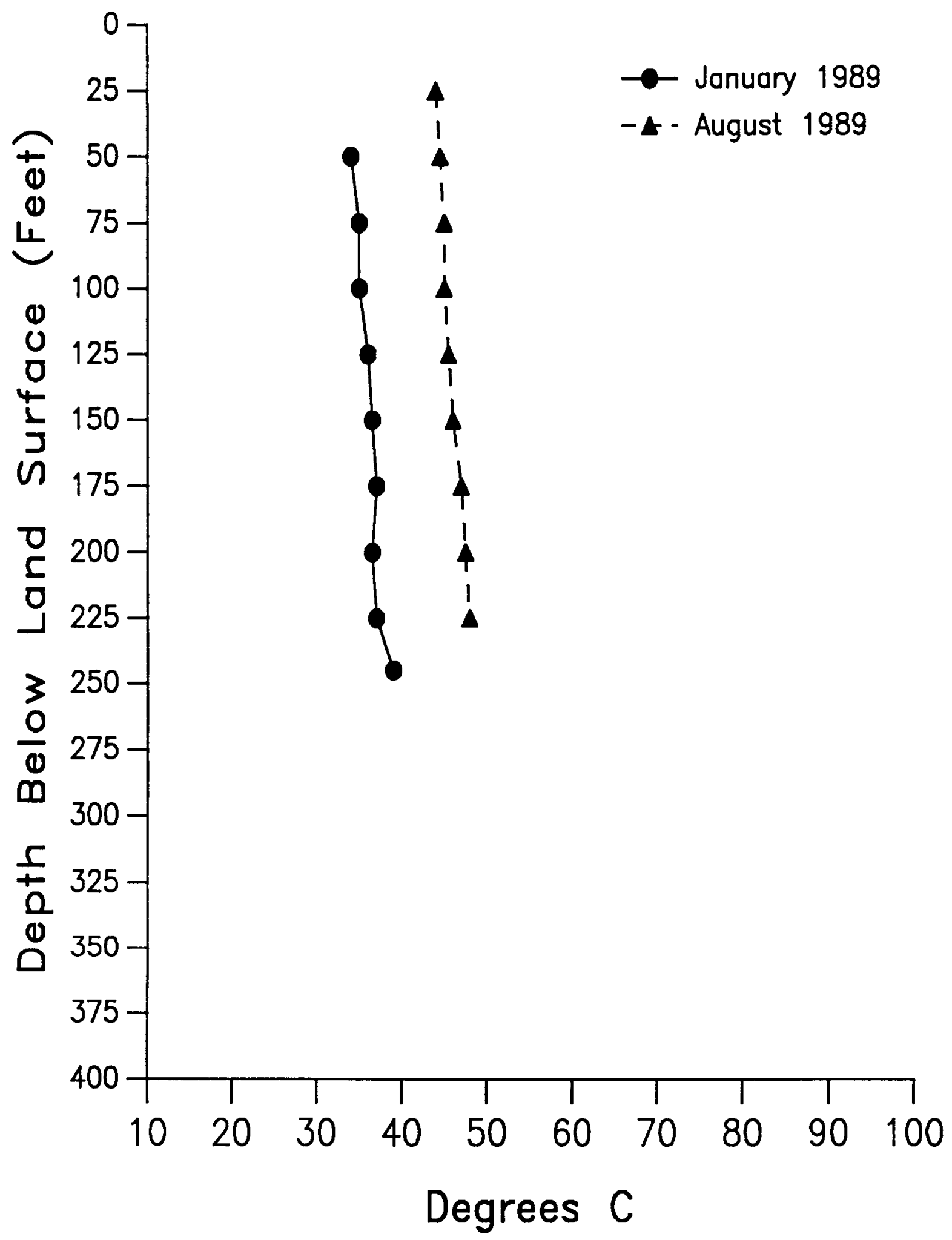

FIGURE 9. Heating and Nonheating Temperature with Depth Profiles for Well 10 (Heat Exchanger, Pumped). 


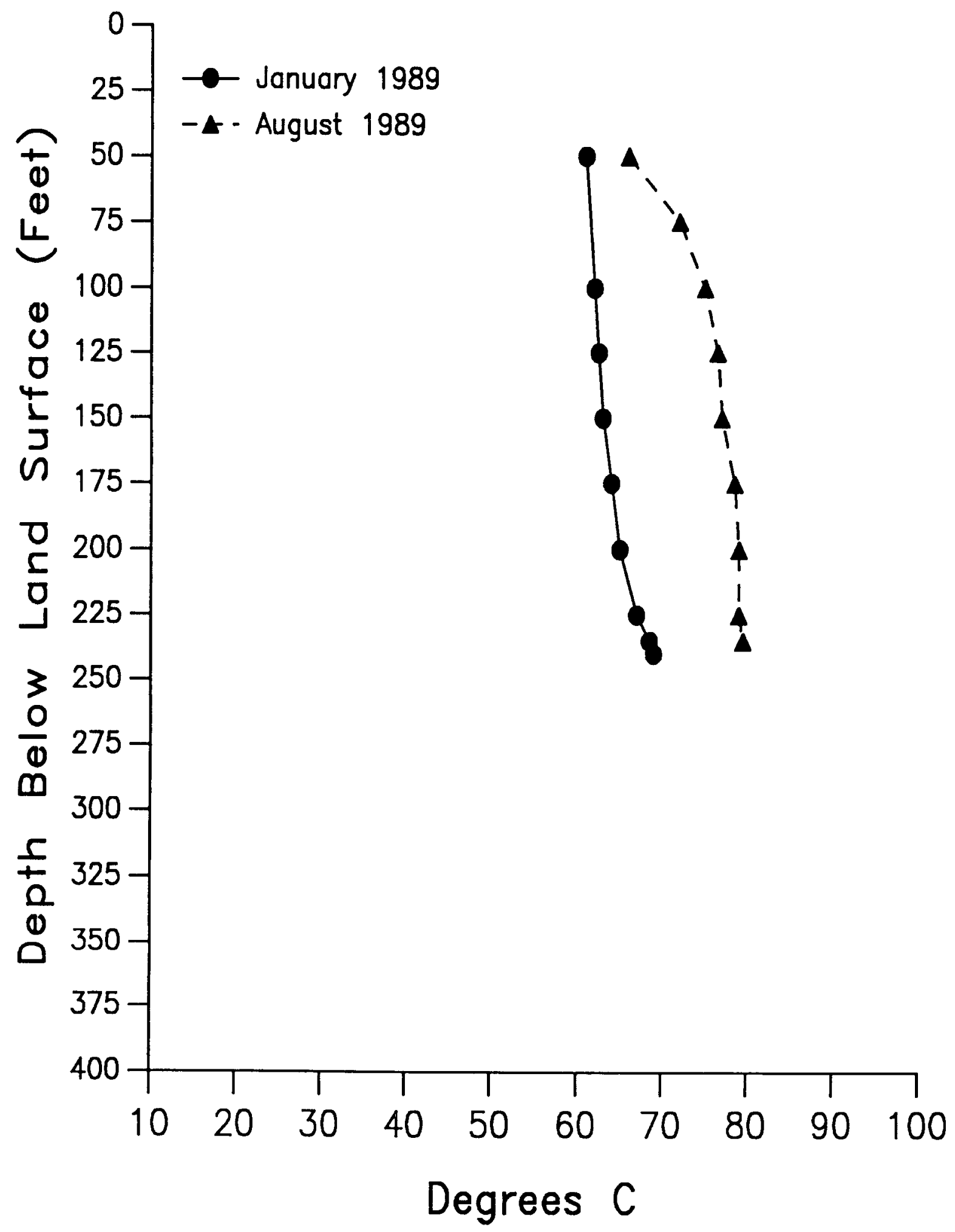

FIGURE 10. Heating and Nonheating Temperature with Depth Profiles for Well 6 (Heat Exchanger, Pumped). 


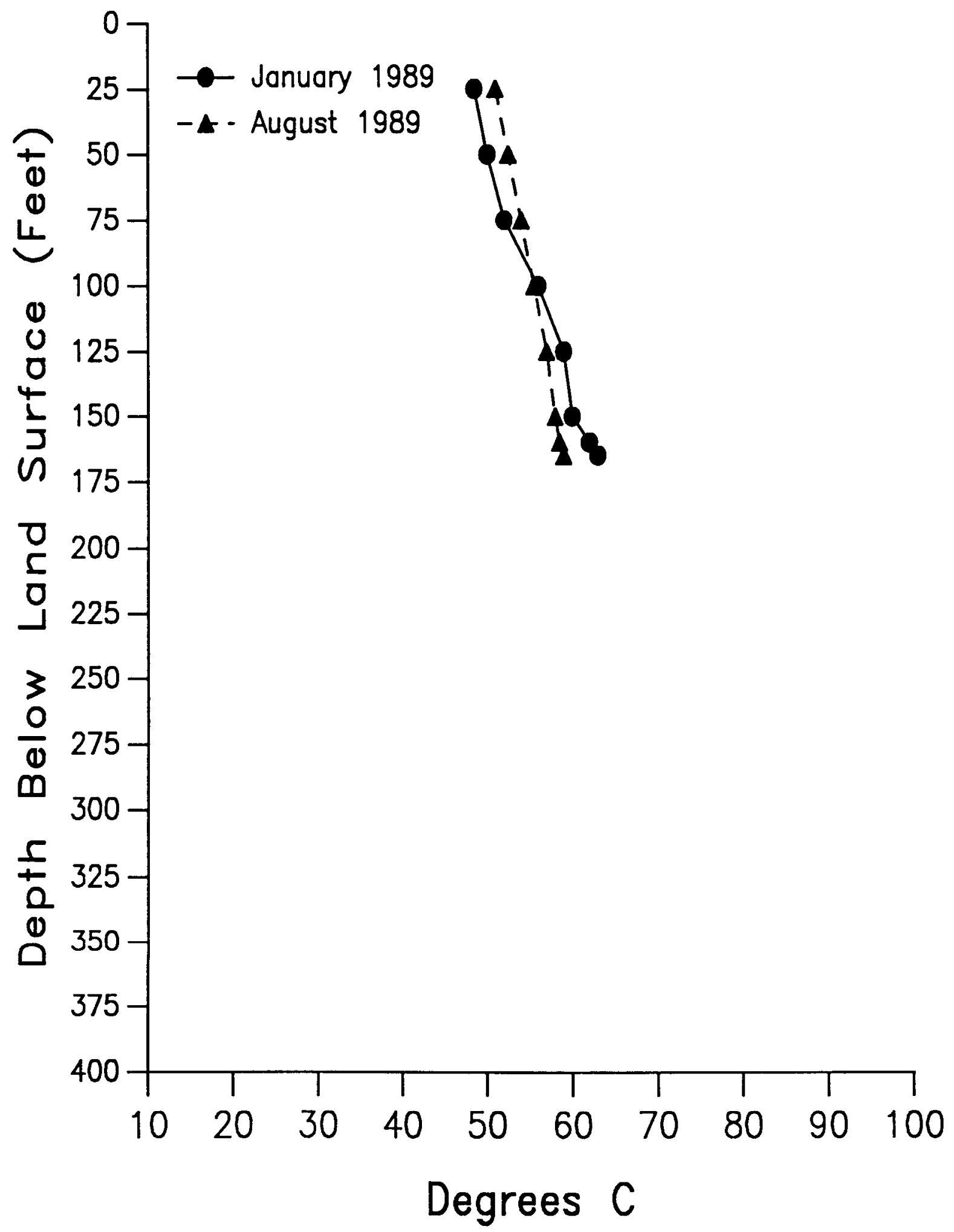

FIGURE 11. Heating and Nonheating Temperature with Depth Profiles for Well 1 (Heat Exchanger, Pumped). 


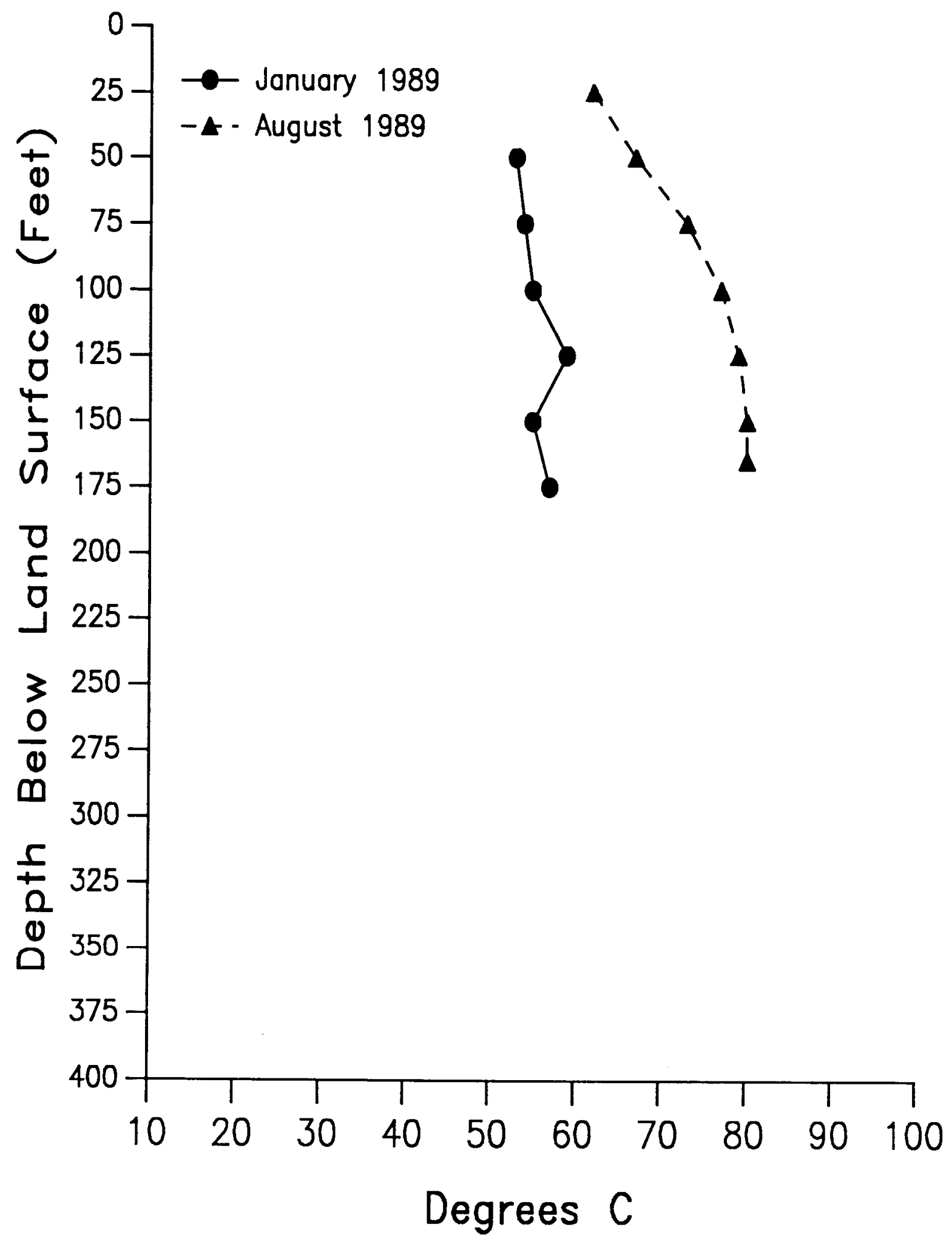

FIGURE 12. Heating and Nonheating Temperature with Depth Profiles for Well 14 (Heat Exchanger, No Pump). 


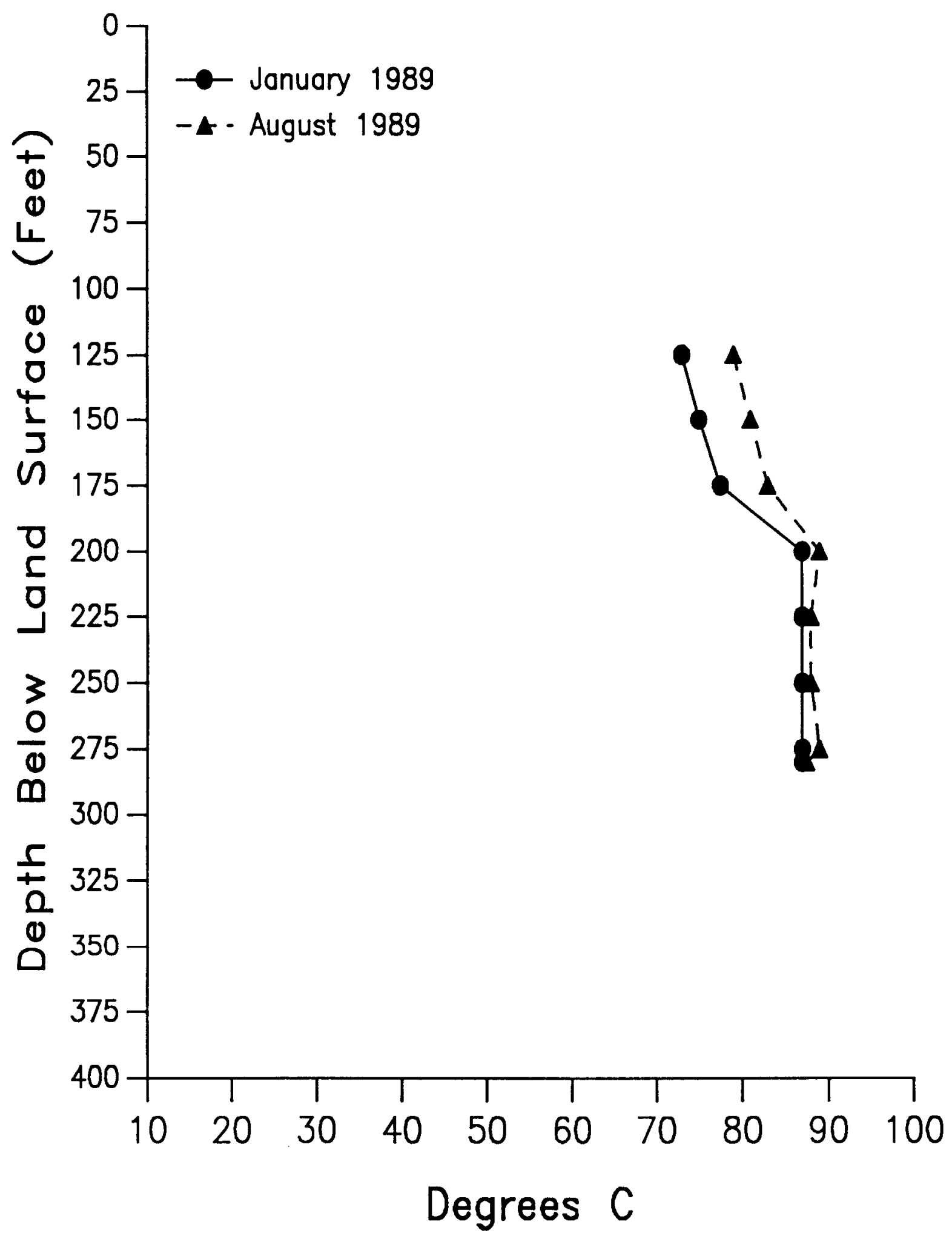

FIGURE 13. Heating and Nonheating Temperature with Depth Profiles for Well 15 (Heat Exchanger, No Pump). 
makes the heat exchange process uneconomic, or at commercial establishments where high heating loads require large volumes of thermal water. Representative heating and nonheating temperature gradient profiles for an extractive well are shown in Figure 14 for Well 17. The heating temperature gradient profiles have higher temperatures throughout the well. This results from the pump pulling in fresh geothermal water into the well during the heating season and the absence of a thermal load in the well bore. This type of well is generally used for space heating only and not as a source of domestic hot water. Therefore, the wells are turned off during the summer months and the water in the well bore cools due to borehole convection.

Six wells in the study group were unused domestic or commercial geothermal wells. Temperature gradient profiles from winter and summer months for two of these wells are shown in Figures 15 and 16 for Well 22 and Well 24, respectively. Temperature data from these wells are believed to be fairly representative of reservoir temperatures due to the absence of thermal load on these wells. Temperatures in the upper portions of the wells were somewhat lower in the winter than in the summer (for example, see Figure 15). This phenomenon is probably the result of convective cooling driven by lower air temperatures during the winter. Temperatures in the bottom of the wells were almost constant throughout the duration of the study (see Figures 15 and 16).

Two wells in the study group were monitoring wells drilled as part of the Flynn and Ghusn (1984) study. Temperature gradient profiles from heating and nonheating periods are shown in Figures 17 and 18 for Horseman's Park (Well 26) and Manzanita Park (Well 25), respectively. Temperatures in these wells were almost constant during the course of the study. Temperatures in these wells are believed to be representative of reservoir temperatures due to the absence of thermal load on the wells. The temperature gradient profiles for Horseman's Park (Well 26) measured in this study (Figure 17) agree with the temperature-depth profile measured by Flynn and Ghusn (1984) in July 1983 (Figure 5). This indicates that at this location, the temperature of the geothermal reservoir has not changed with time. The temperature gradient for Manzanita Park (Well 25), shown in Figure 18 for this study, corresponds to the temperature-depth profile measured by Flynn and Ghusn for June 28, 1983 (see Figure 6). Thus, in this area of the Moana geothermal system, the reservoir temperature has not changed with time.

Although historic maximum temperatures are available from drillers' logs for most of the geothermal wells in the study group, a comparison of these historic values to maximum temperatures measured in this study cannot be used to indicate reservoir temperature changes with time. As previously discussed, the downhole hardware in a geothermal well has an impact on the temperature measurement and the measured maximum temperature will be less than the reservoir temperature. Thus, a direct comparison of historic maximum temperatures to maximum temperatures measured during this study is not meaningful for wells with downhole hardware. 


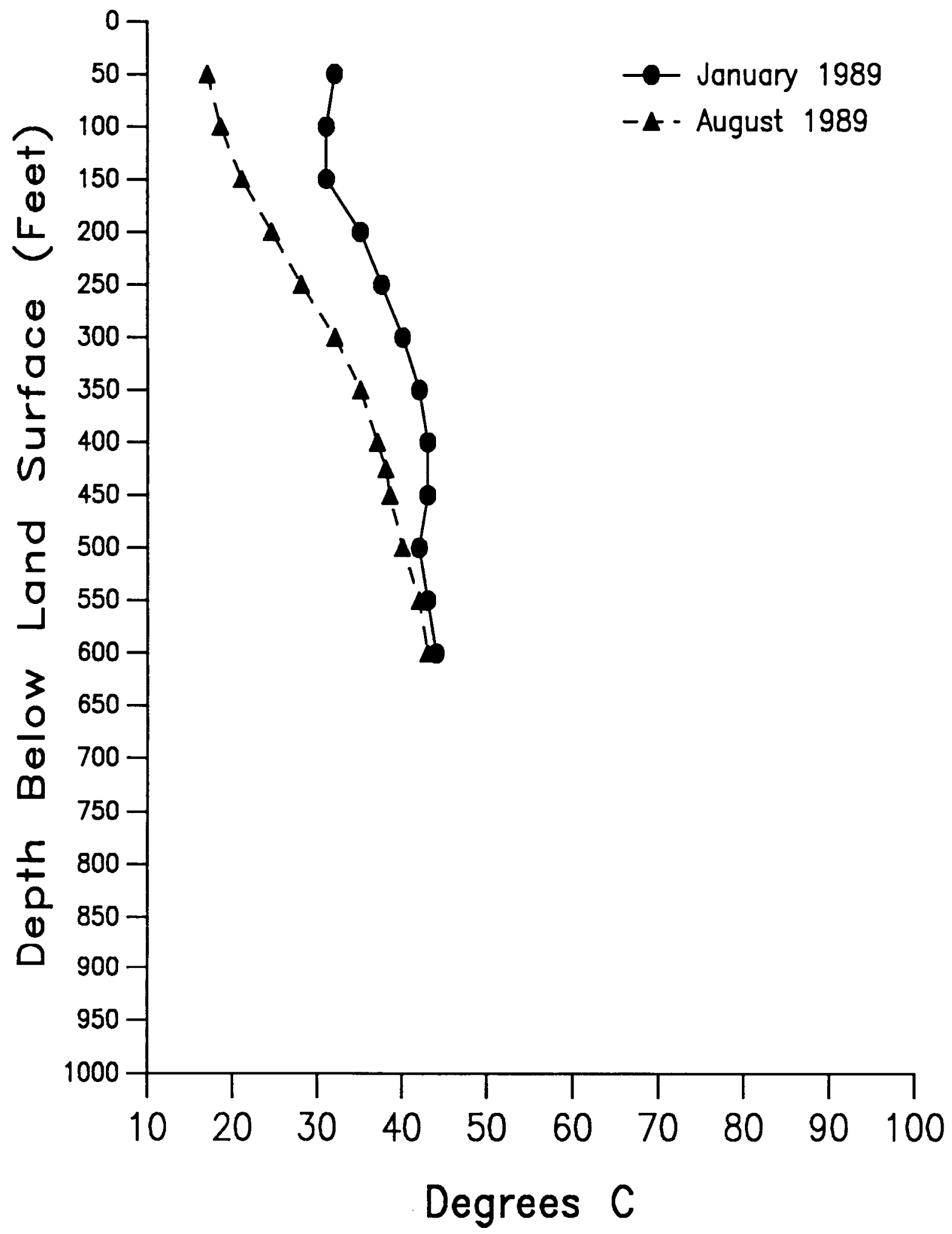

FIGURE 14. Heating and Nonheating Temperature with Depth Profiles for Well 17 (Extractive Well). 


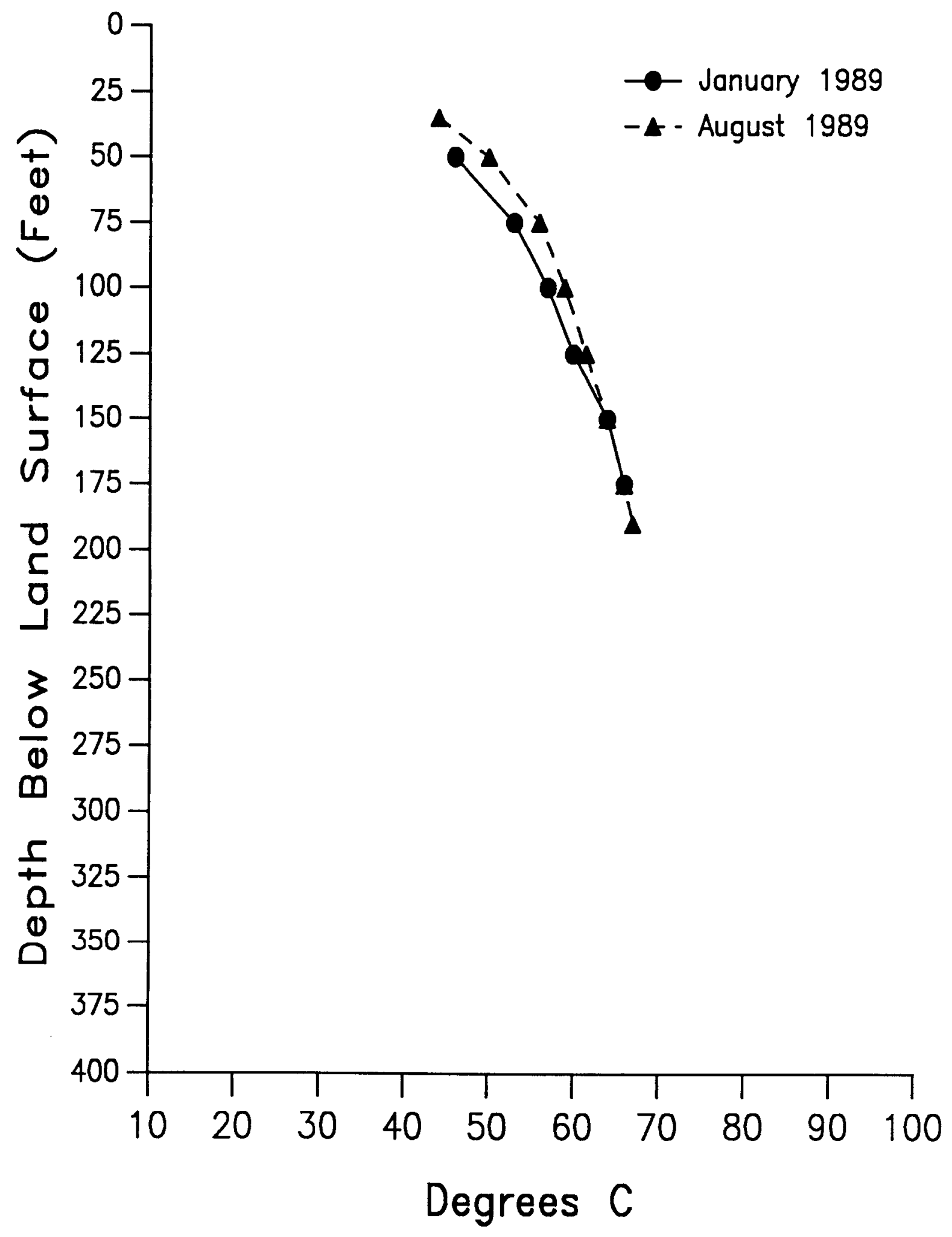

FIGURE 15. Heating and Nonheating Temperature with Depth Profiles for Well 22 (Unused Domestic Well). 


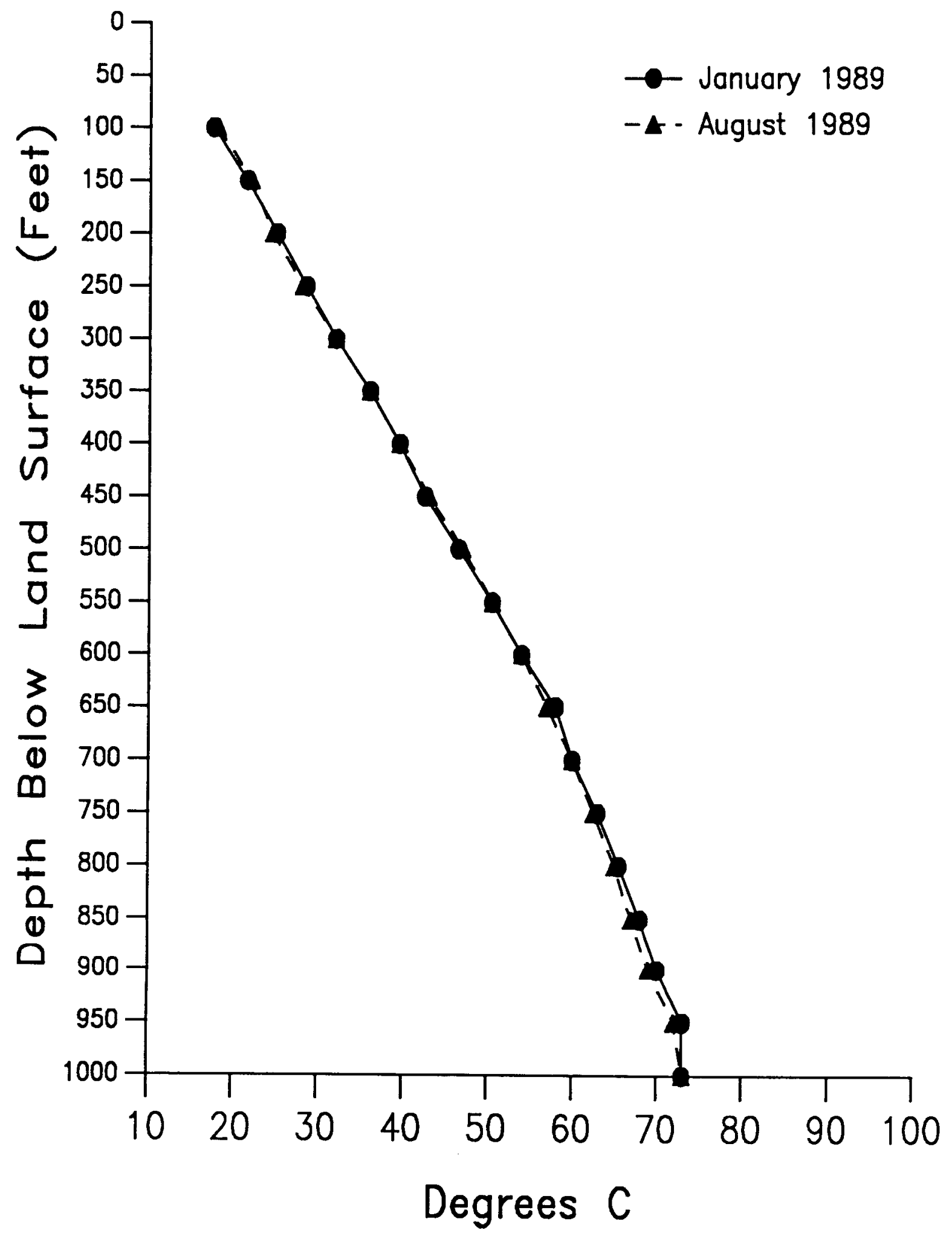

FIGURE 16. Heating and Nonheating Temperature with Depth Profiles for Well 24 (Unused Domestic Well). 


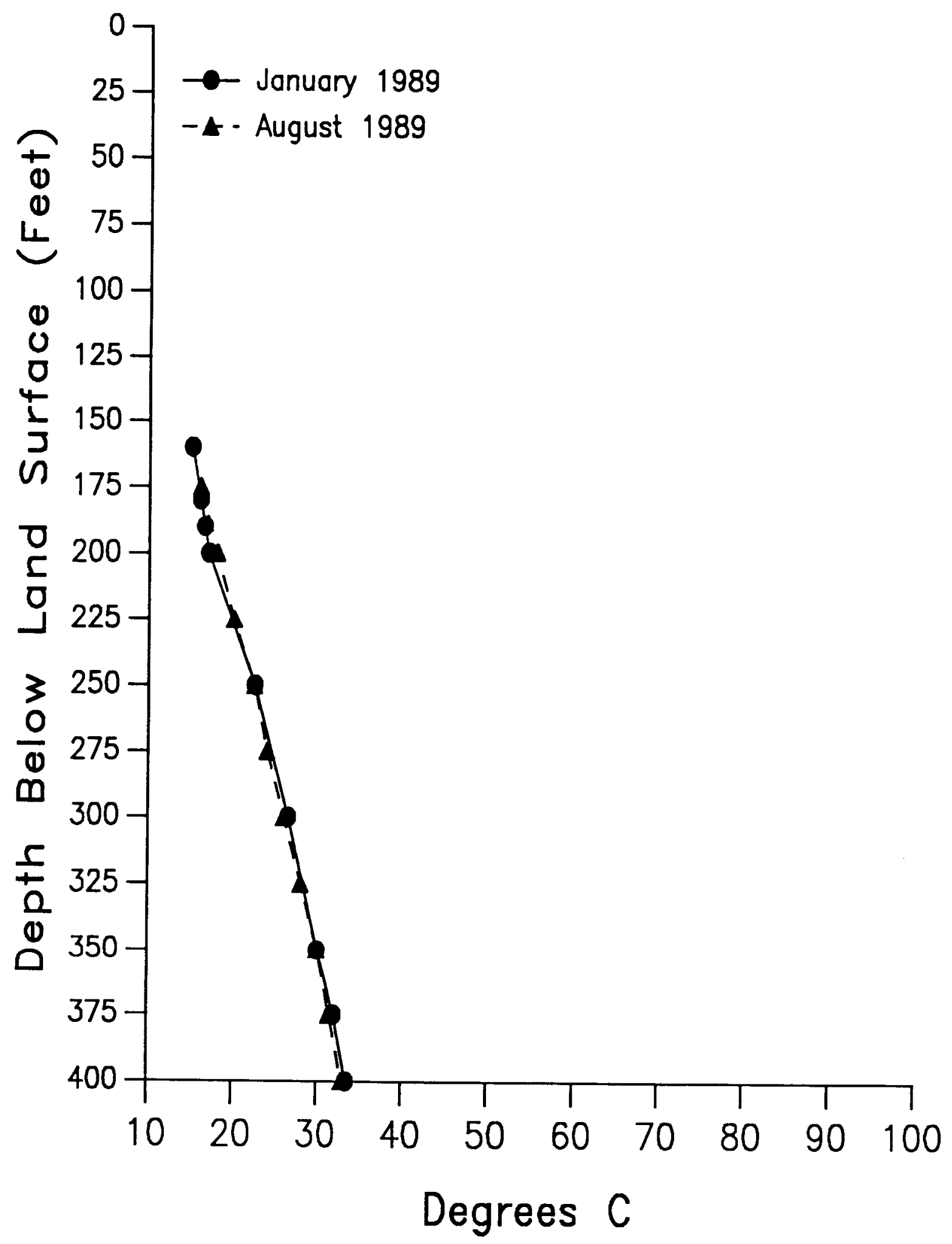

FIGURE 17. Heating and Nonheating Temperature with Depth Profiles for Horseman's Park (Well 26 - Monitoring Well). 


\section{WATER LEVEL DATA}

The measured water level changes in the study group wells are a function of the well construction and the location within the resource area. Plots of water level versus time include the data from the study period, January 1989 to February 1990, and any available historical water level measurements. For most wells, the only available historical data are the water level measurements taken during completion of the wells. The exceptions are the Flynn and Ghusn (1984) monitoring wells which include data from their 1983 study period. The static water levels with time for all 26 geothermal wells are included in Appendix III.

The domestic wells with downhole heat exchangers and pumps had the most variable water levels during the study period. Water levels varied as much as $30 \mathrm{ft}$ (Well 4 Figure 19), with 5 to $10 \mathrm{ft}$ of change being more common (see Figures 20 and 21 for Well 8 and Well 10, respectively). The timing of water level measurement was critical. If the water level was measured shortly after the pump turned off, the measurement would be artificially low. This problem is thought to contribute to the variable nature of these hydrographs. However, several general trends in the hydrographs were observed and are thought to represent geothermal aquifer behavior. Water levels are generally depressed in the winter months, which corresponds to periods of heavy pumpage as shown in Figure 21. In particular, February 1989 was a colder than average period, which could have led to higher pumping rates than normal. Recovery of water levels begins in the spring when pumpage is curtailed. The water levels continue to rise through the summer and early fall. Water levels begin dropping in the late fall and winter with the start-up of the well pumps. All 26 wells in the study group, to some degree, exhibit this general pattern of response.

Comparison of historic data and study period data is possible for six of the ten wells with downhole heat exchangers and pumps. All six wells showed a decline in water level since they were drilled. Most of these wells are in the central portion of the resource area. The high density well placement in this portion of the resource area has aggravated drawdown effects in the geothermal aquifer, which supports Ghusn's (1982) observation of decreasing aquifer pressures in the resource area.

The five domestic wells with heat exchangers and no pump in the study group had the same pattern of response as the wells with pumps as indicated by the water level response for Well 15 in Figure 22. That is, water levels were depressed in the winter months, begin to recover in the spring, continue to recover through the early fall and begin to decline in the late fall or early winter. The response of these wells exhibits their sensitivity to pumpage of surrounding wells.

Comparison of historic and study period data is possible for three of the five wells of this type. All three wells showed a decline in water level since the they were drilled. 


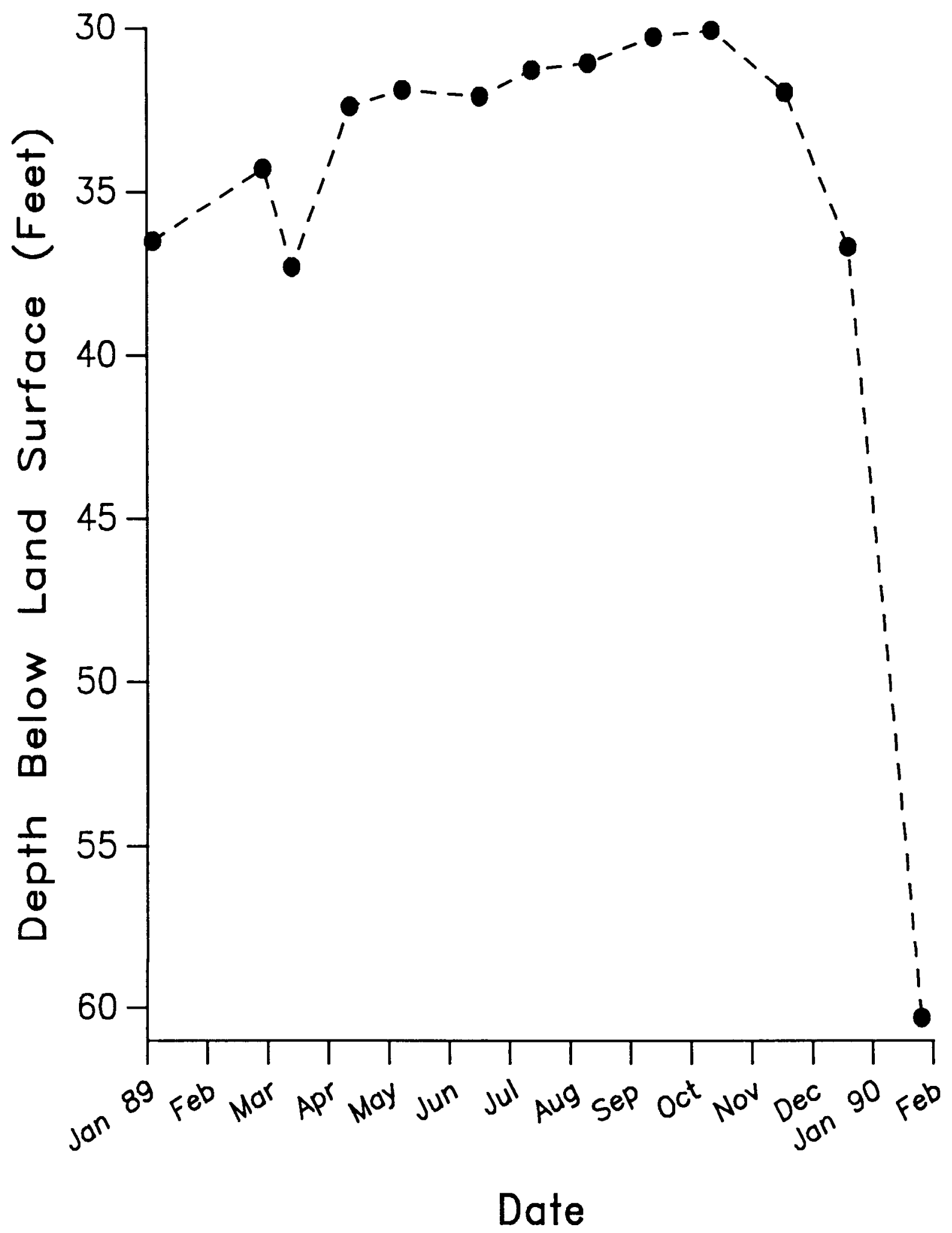

FIGURE 19. Static Water Level with Time for Well 4 (Downhole Heat Exchanger, Pumped). 


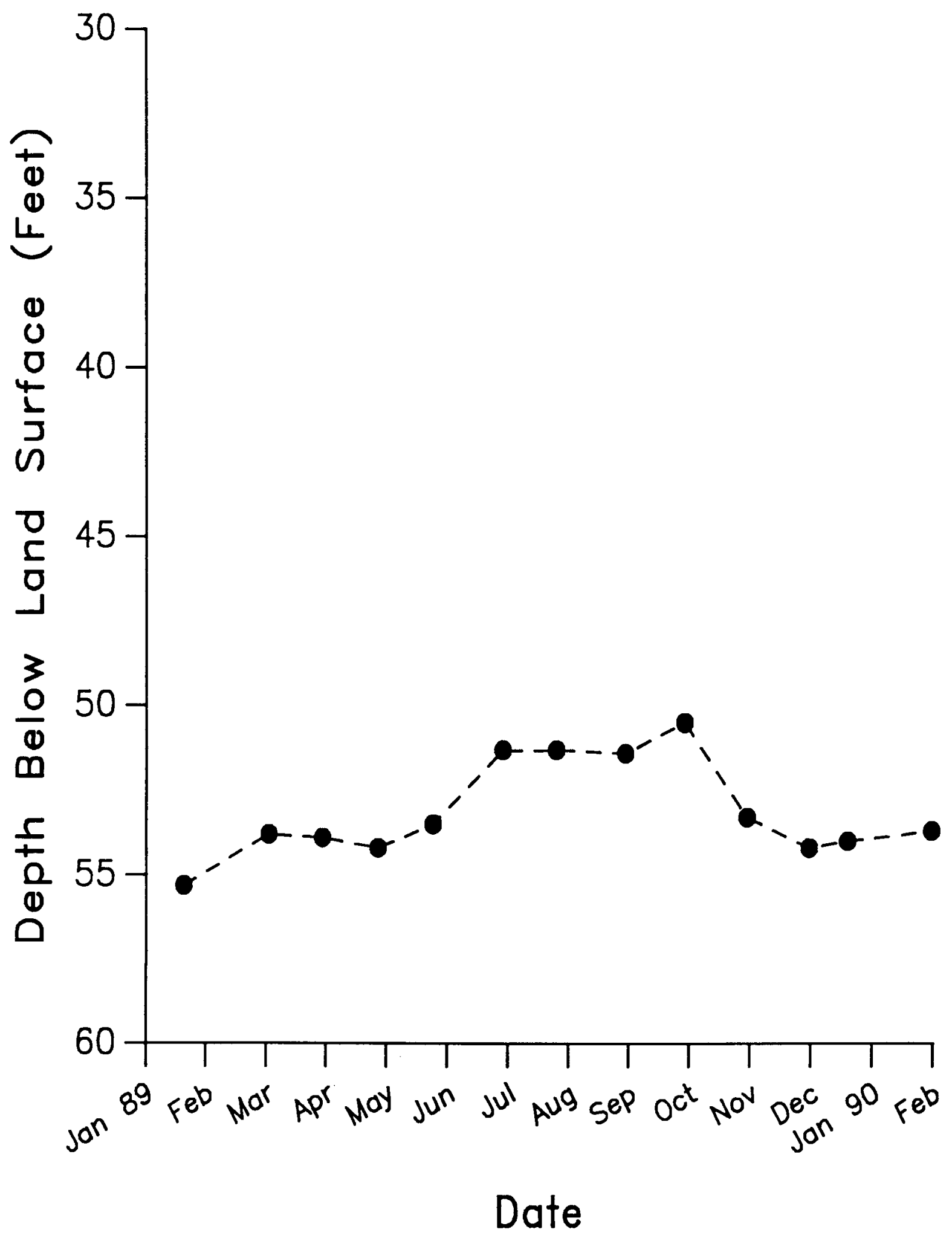

FIGURE 20. Static Water Level with Time for Well 8 (Downhole Heat Exchanger, Pumped). 


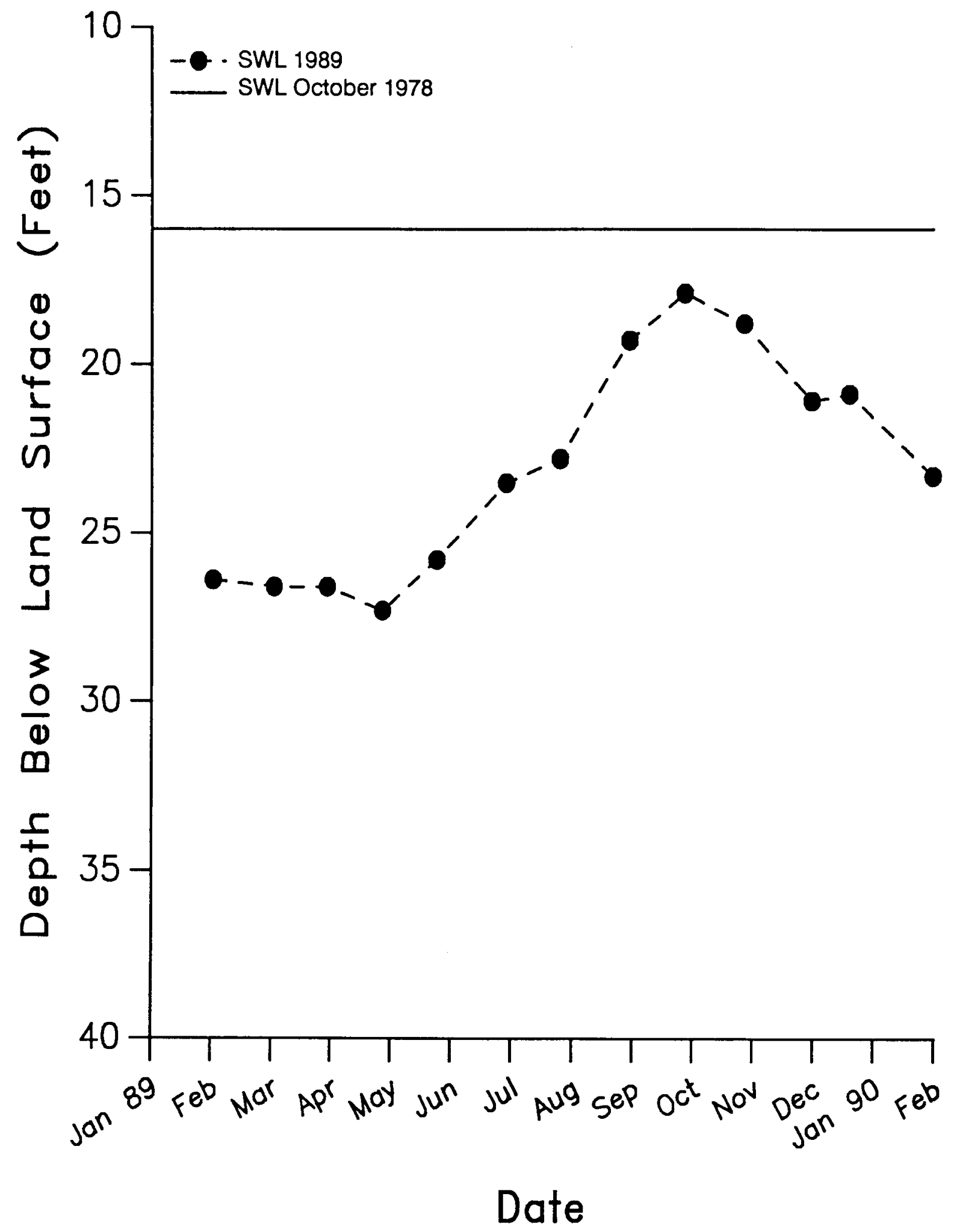

FIGURE 21. Static Water Level with Time for Well 10 (Downhole Heat Exchanger, Pumped). 


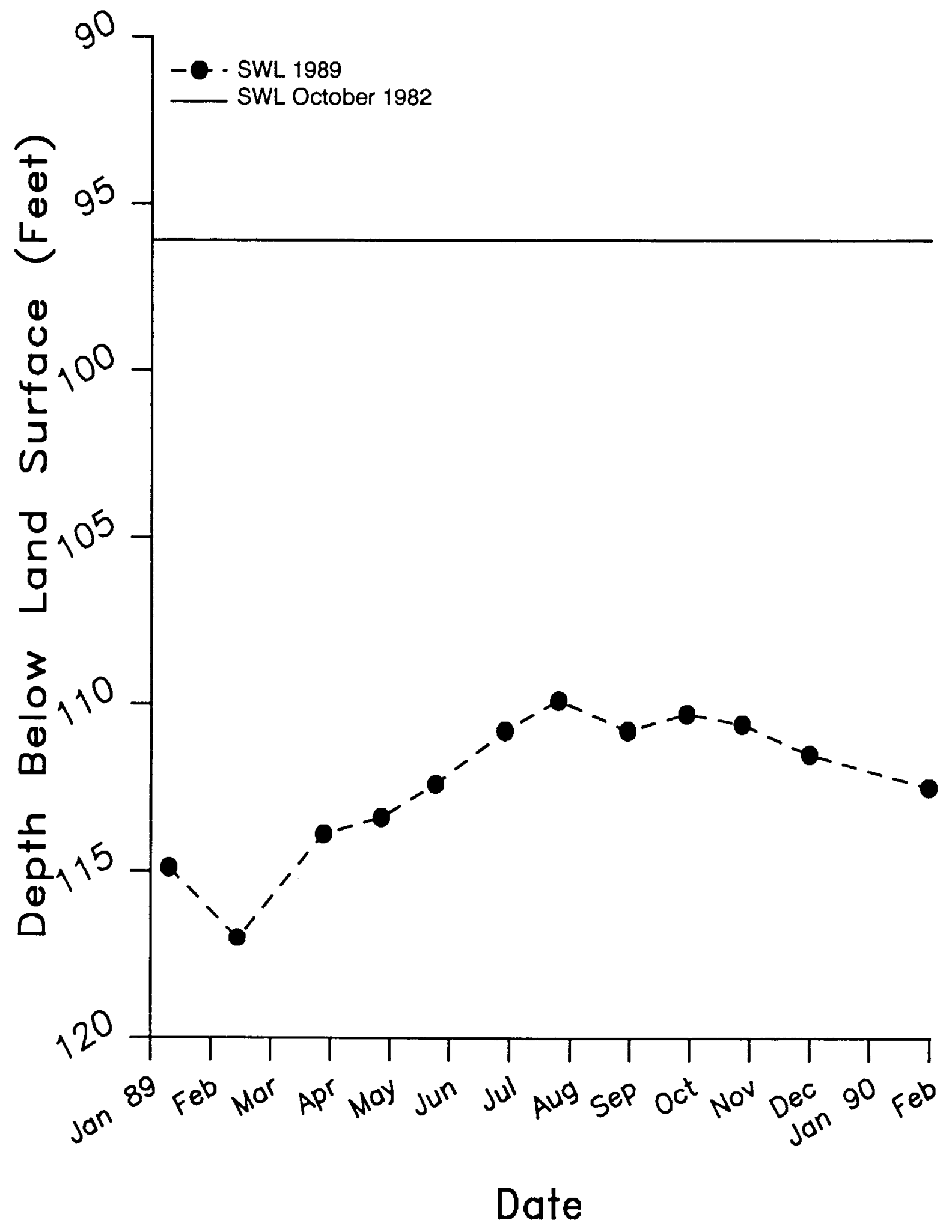

FIGURE 22. Static Water Level with Time for Well 15 (Downhole Heat Exchanger, No Pump). 
Again, these wells are located in the central portion of the resource area, an area of high density well placement. The change in water level is at least $10 \mathrm{ft}$ and as much as $16 \mathrm{ft}$ (Well 14 - Figure 23) since the early 1980s. The rate of decline is over $1 \mathrm{ft} / \mathrm{year}$ for this group of wells. The change in water levels illustrates the transitional state of the geothermal aquifer in these regions.

The three extractive wells had the same seasonal pattern of water level response as the previously discussed wells. Comparison of historic and study period data is possible for all three wells. Depth to water in the extractive wells has remained essentially the same or decreased since these wells were drilled. These wells are located in low temperature portions of the resource area where well densities are low. Two of the wells, Well 16 and Well 17 (Figures 24 and 25, respectively), appear to represent conditions at the eastern and northern boundaries, respectively, of the resource area. The third well, Well 18 (Figure 26), is just north of the area of high well density. These water level data illustrate that the decline in aquifer pressure is concentrated in the central portion of the resource area.

The six unused domestic and commercial wells in the study group, in general, showed a seasonal response of depressed water levels at the onset of the study period in January and recovery during the spring through early fall, as shown in Figure 27 for Well 22. However, three of these wells, Well 19, Well 21 and Well 23, failed to show a decline in water level with the onset of the heating season. An example of this behavior is presented in Figure 28 for Well 21. This response or lack of response may be due in part to the mild weather in the fall of 1989. Additionally, Well 21 and Well 23 are located away from the central portion of the resource area.

The two monitoring wells show the seasonal pattern of water level decline, recovery, and renewed decline. The long-term behavior of these wells is of greater interest. The Manzanita Park well (Well 25) has shown an overall decline in water level as observed in Figure 29 since the Flynn and Ghusn (1984) investigation in 1983. This well is located in the eastern portion of the resource area and downgradient from the area of high density well placement. These data suggest that the decrease in aquifer pressure identified in the central resource area is propagating downgradient. The Horseman's Park well (Well 26) has shown an overall rise in water level since 1983 (see Figure 30). This well is located near the western boundary of the resource area. These data suggest that the rate of recharge to the geothermal aquifer may actually be increasing and lend credence to the idea of pumpage-induced drawdown in the central portion of the resource area.

Flynn and Ghusn (1984) developed piezometric surface elevations of thermal fluids in the Moana area, previously shown in Figure 4. Based on water level data collected in this study, a representative hydraulic head distribution for the nonheating period of September 1989 was constructed and is presented in Figure 31. In general, the 


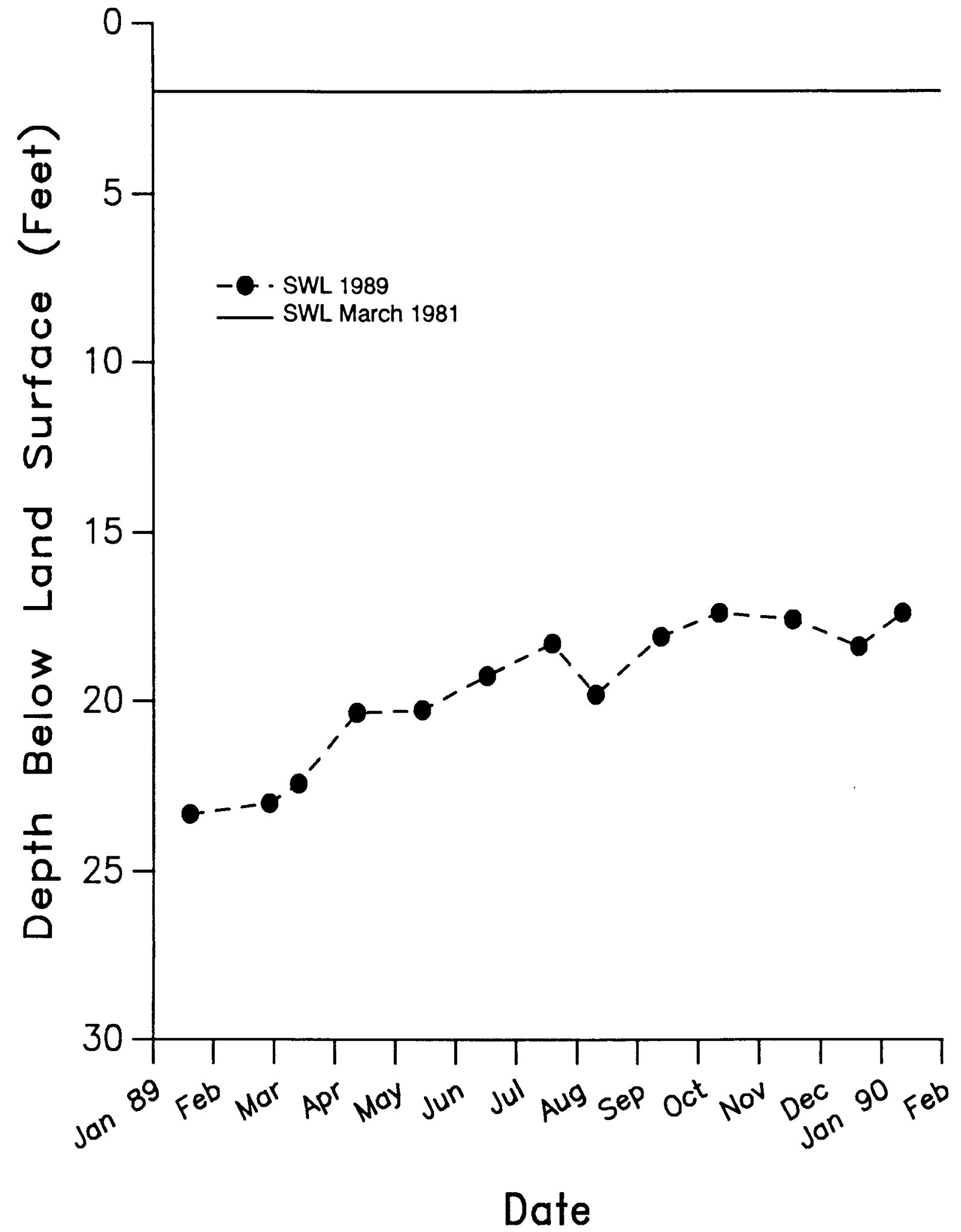

FIGURE 23. Static Water Level with Time for Well 14 (Downhole Heat Exchanger, No Pump). 


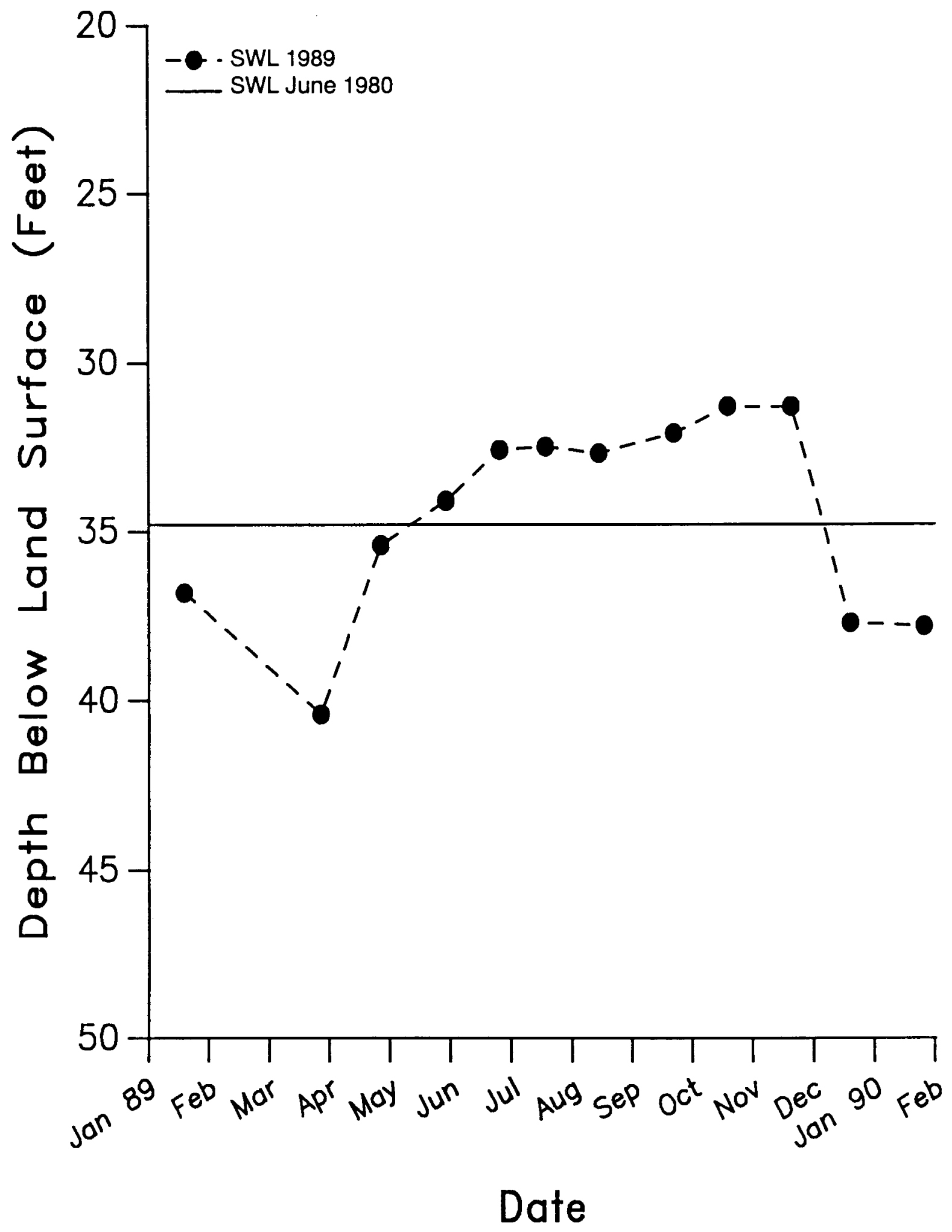

FIGURE 24. Static Water Level with Time for Well 16 (Extractive Well). 


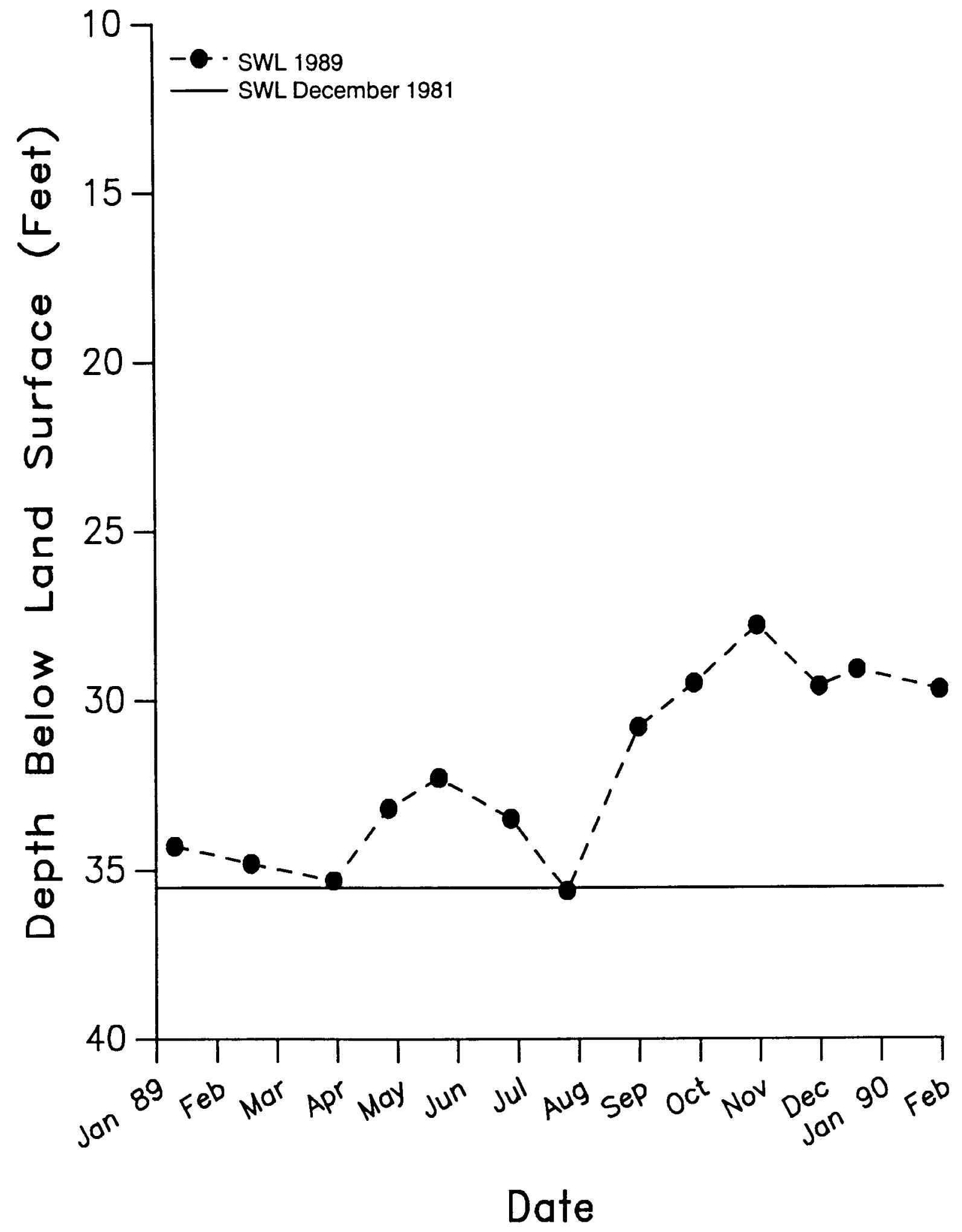

FIGURE 25. Static Water Level with Time for Well 17 (Extractive Well). 


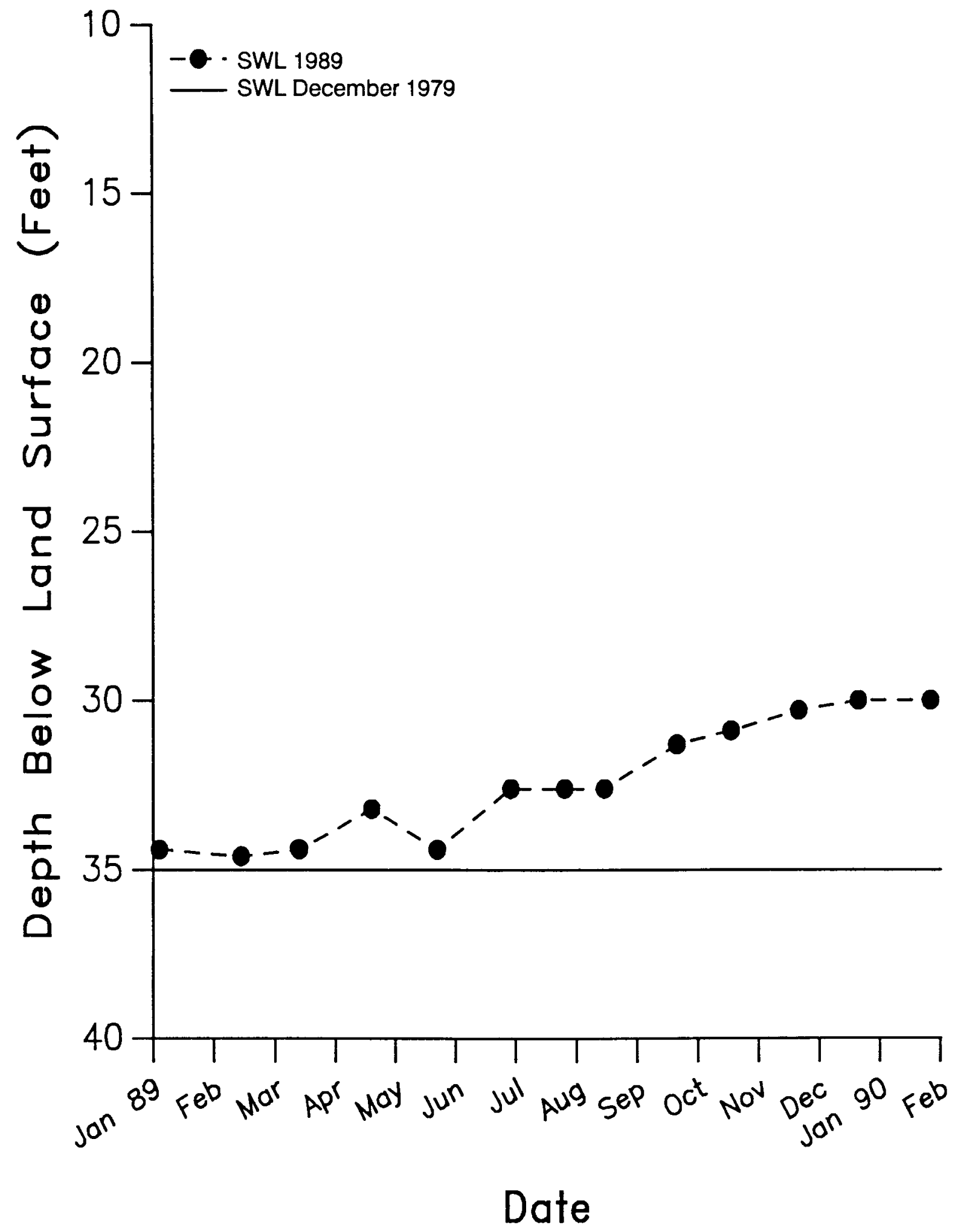

FIGURE 26. Static Water Level with Time for Well 18 (Extractive Well). 


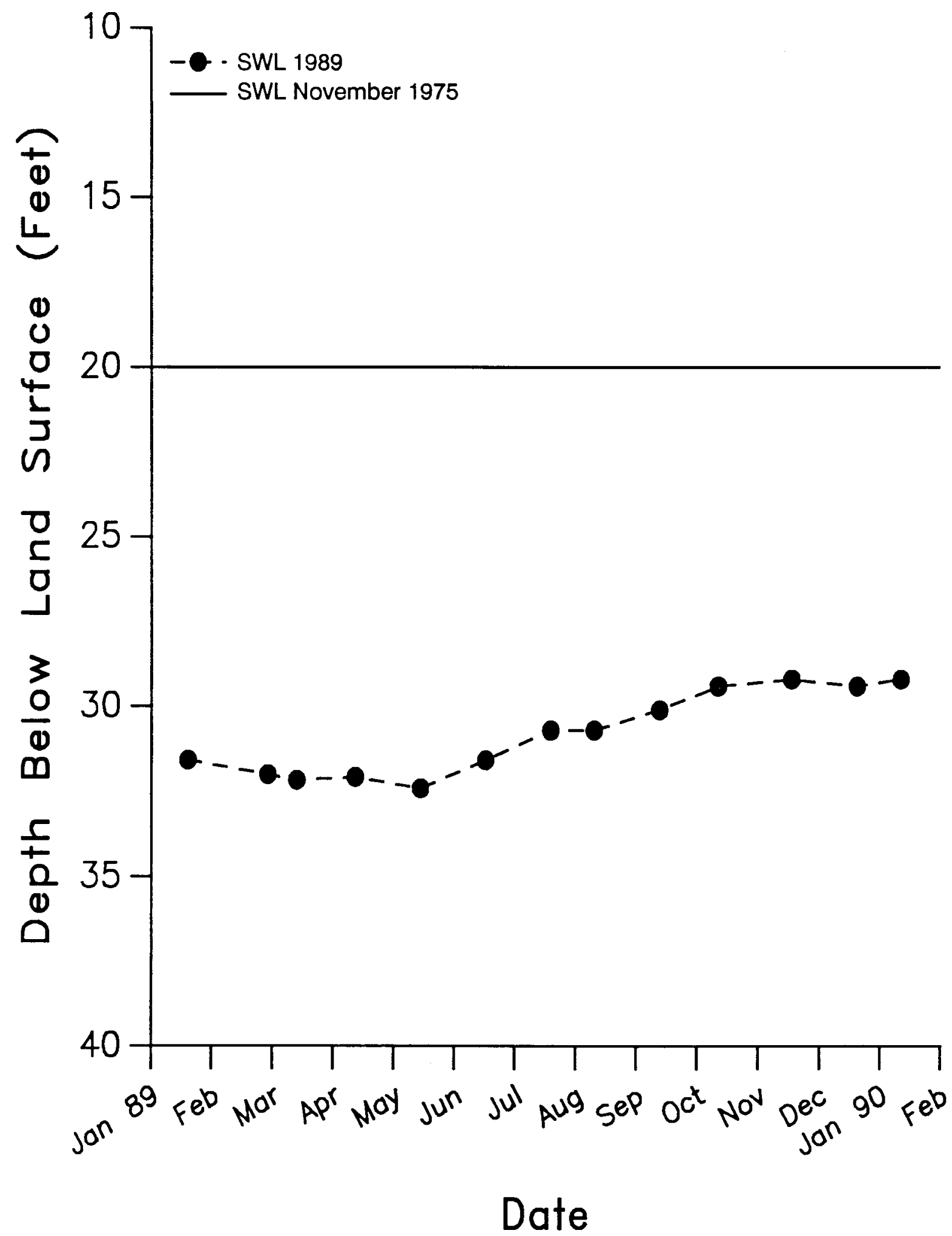

FIGURE 27. Static Water Level with Time for Well 22 (Unused Domestic Well). 


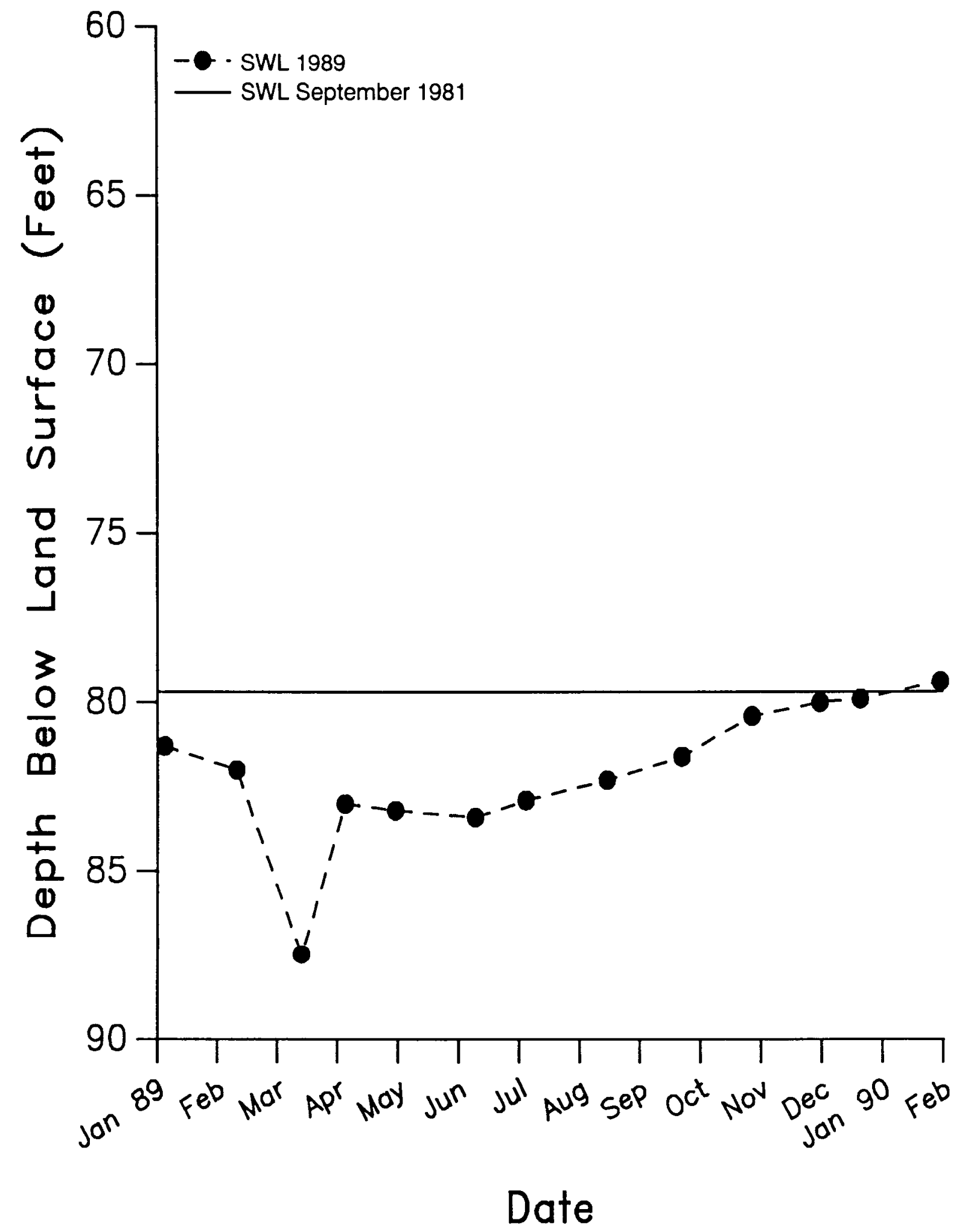

FIGURE 28. Static Water Level with Time for Well 21 (Unused Domestic Well). 


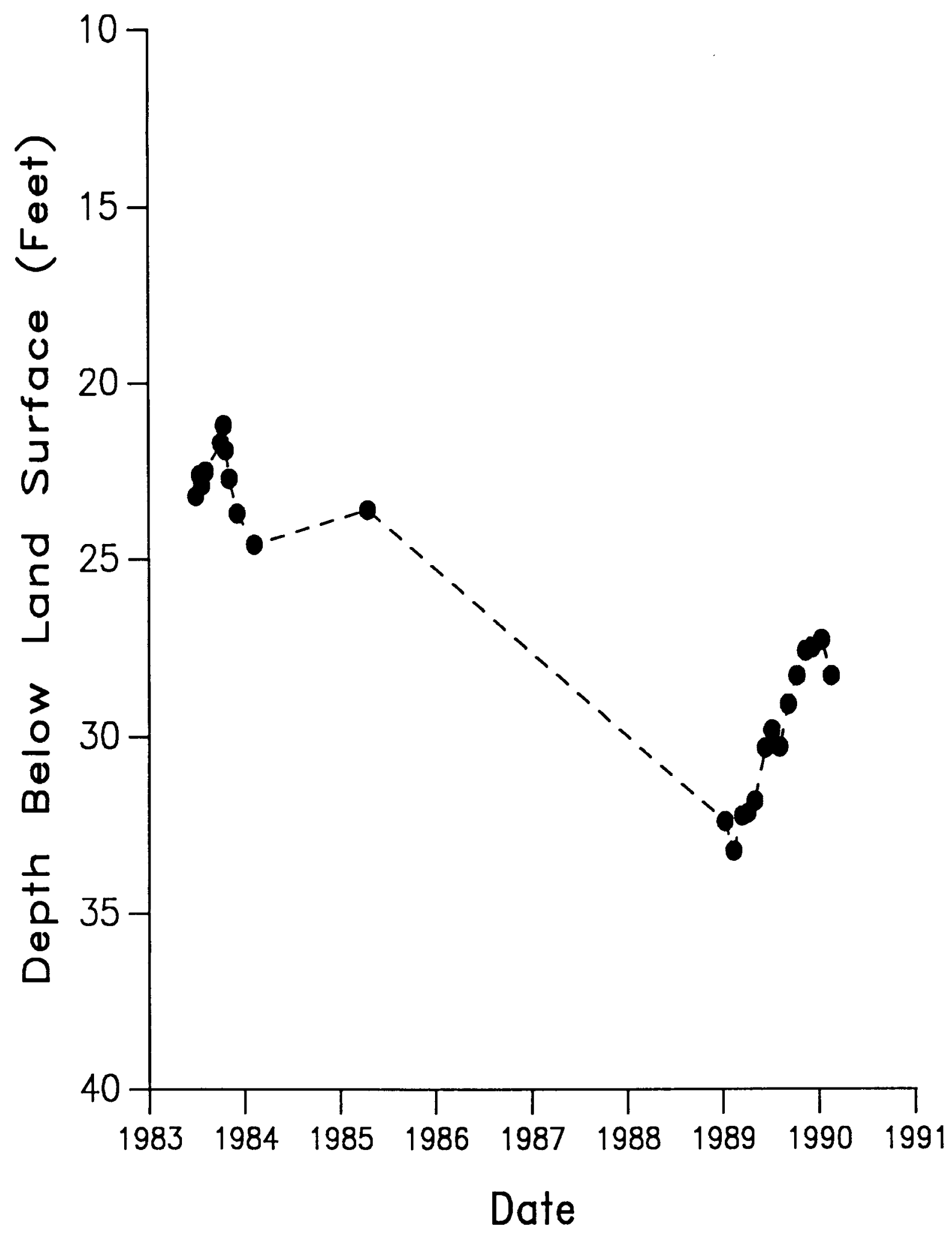

FIGURE 29. Static Water Level with Time for Manzanita Park (Well 25 - Monitoring Well). 


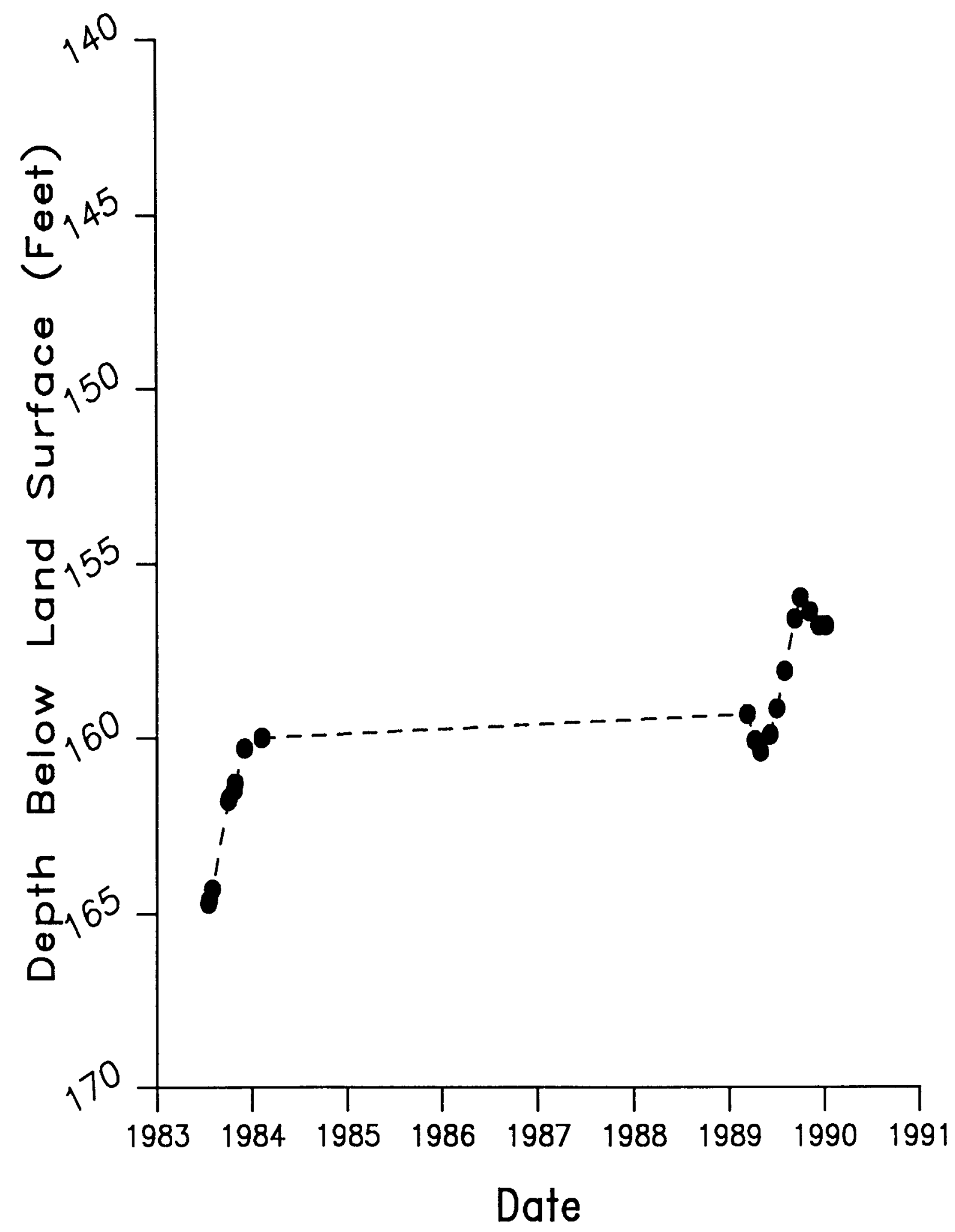

FIGURE 30. Static Water Level with Time for Horseman's Park (Well 26 - Monitoring Well). 


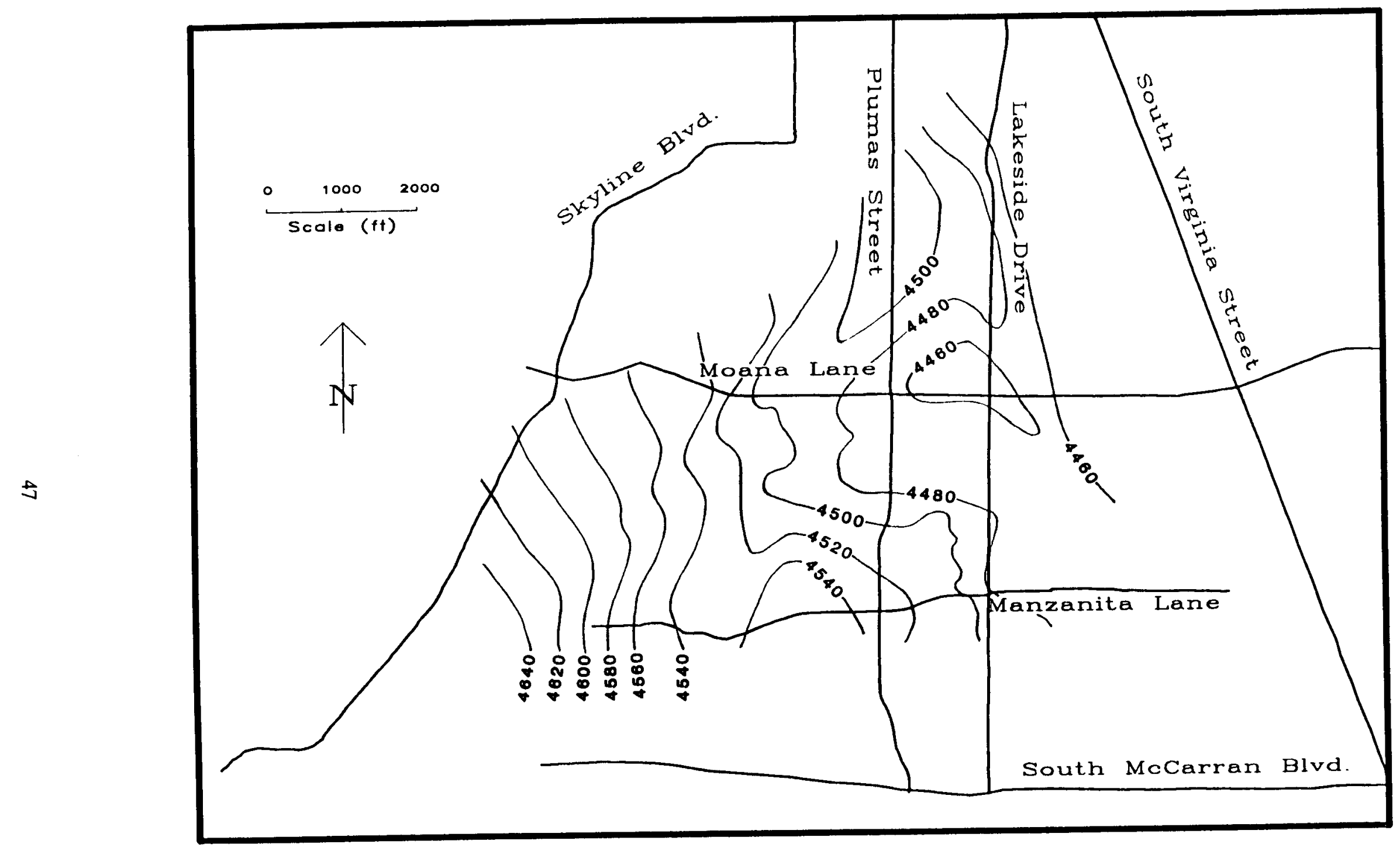

FIGURE 31. Contours of Hydraulic Head in the Moana Geothermal Area for September 1989. 
gradient of hydraulic heads and general spatial patterns obtained in this study are very similar to those found in the Flynn and Ghusn study, except in the northern portion of the study area by Plumas Street. The water level measurement for Well 23 indicated higher hydraulic head than other wells nearby and this value influenced the contours. Well 23 is completed in a different layer than the nearby wells, which may account for its anomalous value. 


\section{GROUNDWATER CHEMISTRY}

\section{CHEMICAL COMPOSITION}

Groundwater samples collected in the Moana area can be broadly classified into two types: 1) nonthermal, bicarbonate-dominated water; and 2) thermal, sulfatedominated water. Mixing between nonthermal and thermal waters has been identified and can cause significant variation in the chemical composition of each water type (Scheibach, 1975).

The nonthermal waters of the area are of good quality and suitable for most uses. Table 2 contains analyses of nonthermal waters from the eastern and southern boundaries of the Moana resource area. These sample locations are upgradient of the resource area and are thought to have little or no chemical contribution from thermal waters. Major chemical constituents are, in order of decreasing concentration, bicarbonate, silica, sulfate, calcium, sodium, magnesium, nitrate, chloride, and potassium.

Thermal waters are of poorer quality with concentrations of dissolved solids (estimated by ion summation) in the hottest waters of around $1,000 \mathrm{mg} / \mathrm{l}$. Table 3 contains information from various studies on the chemical analyses of waters from geothermal wells in the Moana resource area, with samples representing a broad cross section of thermal waters from the area. Table 3 includes both end member and mixed examples of thermal waters. Moana thermal waters contain, in order of decreasing concentration, sulfate, sodium, silica, bicarbonate, chloride, calcium and potassium, as well as minor amounts of fluoride, magnesium, boron, lithium, and arsenic.

\section{MIXING}

The chemical constituents present in thermal waters are often controlled by temperature and pressure-dependent water-rock reactions. The exceptions are chloride, bromine, boron, and cesium, which act as soluble elements in most situations and, to a limited extent, fluoride, lithium, and arsenic in waters at deep levels (Ellis, 1970). These elements tend to concentrate in solution once liberated from rock and do not readily enter into secondary mineral structures. Examination of the behavior of these elements can provide insight into processes, such as mixing, boiling and conductive cooling, which may affect the geothermal aquifer. Mixing of thermal and nonthermal waters is believed to be an important aquifer process and control on temperature in the Moana resource area.

Thermal waters of the Moana area are enriched in chloride, boron, fluoride, lithium, and arsenic in comparison to the nonthermal waters. The concentrations of these elements are not affected by temperature and pressure-dependent water-rock reactions within the geothermal aquifer and are considered a signature of the thermal waters. Since this signature is unaffected by temperature, decreasing concentrations of these elements along with a simultaneous decrease in temperature indicate mixing with 
TABLE 2. CHEMICAL ANALYSES OF NONTHERMAL WATERS FROM THE SOUTHERN AND EASTERN BOUNDARIES OF THE MOANA GEOTHERMAL AREA.

\begin{tabular}{|c|c|c|c|c|c|c|c|c|c|c|c|c|c|c|c|c|c|}
\hline $\begin{array}{l}\text { Address } \\
\text { Location }^{1}\end{array}$ & Date & $\begin{array}{l}\text { Temp } \\
{ }^{\circ} \mathrm{C}\end{array}$ & $\mathrm{pH}$ & $\begin{array}{c}\mathrm{EC} \\
\mu \mathrm{mhos} / \mathrm{cm}\end{array}$ & $\begin{array}{l}\mathrm{SiO}_{2} \\
\mathrm{mg} / \mathrm{l}\end{array}$ & $\begin{array}{c}\mathrm{Na} \\
\mathrm{mg} / 1\end{array}$ & $\begin{array}{c}\mathrm{K} \\
\mathrm{mg} / \mathrm{l}\end{array}$ & $\begin{array}{c}\mathrm{Li} \\
\mathrm{mg} / \mathrm{l}\end{array}$ & $\begin{array}{c}\mathrm{Ca} \\
\mathrm{mg} / \mathrm{l}\end{array}$ & $\begin{array}{l}\mathrm{Mg} \\
\mathrm{mg} / \mathrm{l}\end{array}$ & $\begin{array}{c}\mathrm{B} \\
\mathrm{mg} / \mathrm{l}\end{array}$ & $\begin{array}{l}\mathrm{SO}_{4} \\
\mathrm{mg} / \mathrm{l}\end{array}$ & $\begin{array}{c}\mathrm{Cl} \\
\mathrm{mg} / \mathrm{l}\end{array}$ & $\begin{array}{c}\mathrm{HCO}_{3} \\
\mathrm{mg} / \mathrm{l}\end{array}$ & $\begin{array}{l}\mathrm{CO}_{3} \\
\mathrm{mg} / 1\end{array}$ & $\begin{array}{c}\mathrm{F} \\
\mathrm{mg} / \mathrm{l}\end{array}$ & $\begin{array}{c}\text { As } \\
\mathrm{mg} / \mathrm{l}\end{array}$ \\
\hline $\begin{array}{l}4890 \text { Piedmont } \\
\text { T19N R19E } 22\end{array}$ & $7-20-79$ & Cold & 7.63 & - & - & 17 & 7 & - & 29 & 19 & - & 14 & 4 & 195 & - & 0.09 & 0.005 \\
\hline $\begin{array}{l}1705 \text { Davis } \\
\text { T19N R19E } 34\end{array}$ & $1-24-85$ & Cold & 7.48 & 399 & 66 & 30 & 4 & - & 34 & 15 & 0.0 & 25 & 5 & 217 & 0 & 0.17 & 0.005 \\
\hline $\begin{array}{l}8355 \text { Lakeside } \\
\text { T19N R19E } 34\end{array}$ & $5-3-85$ & Cold & 7.70 & 325 & 73 & 22 & 5 & - & 27 & 12 & 0.0 & 10 & 2 & 188 & 0 & 0.10 & 0.007 \\
\hline $\begin{array}{l}\text { Lakeridge and Hash } \\
\text { T19N R19E 35AA }\end{array}$ & $1-21-75$ & 19.4 & 7.80 & - & - & 24 & 3 & - & 24 & 7 & - & 27 & 4 & 124 & - & 0.06 & 0.010 \\
\hline $\begin{array}{l}\text { 6601 Lakeside } \\
\text { T19N R19E } 35\end{array}$ & 4-15-87 & Cold & 7.65 & 482 & 82 & 38 & 5 & - & 42 & 12 & 0.1 & 42 & 5 & 232 & 0 & 0.32 & 0.024 \\
\hline $\begin{array}{l}\text { Lakeside and Evans Cr. } \\
\text { T19N R19E } 35\end{array}$ & $3-06-80$ & 12.2 & 7.20 & - & - & 29 & 4 & - & 32 & 11 & - & 49 & 2 & 149 & 0 & 0.26 & 0.000 \\
\hline $\begin{array}{l}2770 \text { Del Monte } \\
\text { T19N R19E } 35\end{array}$ & $9-08-81$ & Cold & 7.69 & - & 68 & 32 & 4 & - & 48 & 22 & 0.1 & 19 & 4 & 303 & 0 & 0.30 & 0.005 \\
\hline $\begin{array}{l}\text { SPPCO Lakeside Well } \\
\text { T19N R 19E 35AA }\end{array}$ & $6-18-86$ & 14.5 & 7.52 & 356 & 68 & 22 & 3 & - & 33 & 11 & 0.1 & 32 & 5 & 171 & 0 & 0.18 & 0.008 \\
\hline
\end{tabular}

Location ${ }^{1}$ - based on Township, Range, and Section.

Data Source: laboratory records from Nevada State Health Laboratory, Nevada Division of Health.

- (data not available) 
TABLE 3. CHEMICAL ANALYSES OF THERMAL WATERS FROM THE MOANA GEOTHERMAL AREA.

\begin{tabular}{|c|c|c|c|c|c|c|c|c|c|c|c|c|c|c|c|c|c|}
\hline Address & Date & $\begin{array}{c}\text { Temp } \\
{ }^{\circ} \mathrm{C}\end{array}$ & $\mathrm{pH}$ & $\begin{array}{c}\mathrm{EC} \\
\mu \mathrm{mhos} / \mathrm{cm}\end{array}$ & $\begin{array}{l}\mathrm{SiO}_{2} \\
\mathrm{mg} / \mathrm{l}\end{array}$ & $\begin{array}{l}\mathrm{Na} \\
\mathrm{mg} / \mathrm{l}\end{array}$ & $\begin{array}{c}\mathrm{K} \\
\mathrm{mg} / \mathrm{I}\end{array}$ & $\begin{array}{c}\mathrm{Li} \\
\mathrm{mg} / \mathrm{l}\end{array}$ & $\begin{array}{c}\mathrm{Ca} \\
\mathrm{mg} / 1\end{array}$ & $\begin{array}{c}\mathrm{Mg} \\
\mathrm{mg} / \mathrm{l}\end{array}$ & $\begin{array}{c}\mathrm{B} \\
\mathrm{mg} / \mathrm{l}\end{array}$ & $\begin{array}{l}\mathrm{SO}_{4} \\
\mathrm{mg} / \mathrm{l}\end{array}$ & $\begin{array}{c}\mathrm{Cl} \\
\mathrm{mg} / \mathrm{l}\end{array}$ & $\begin{array}{c}\mathrm{HCO}_{3} \\
\mathrm{mg} / \mathrm{l}\end{array}$ & $\begin{array}{l}\mathrm{CO}_{3} \\
\mathrm{mg} / \mathrm{l}\end{array}$ & $\begin{array}{c}\mathrm{F} \\
\mathrm{mg} / \mathrm{l}\end{array}$ & $\begin{array}{c}\text { As } \\
\mathrm{mg} / \mathrm{l}\end{array}$ \\
\hline a2600 Eastshore1 & $9-27-89$ & 54.0 & 8.28 & 971 & 93.7 & 189 & 9.42 & 0.14 & 20.3 & 0.98 & 1.2 & 281 & 30.1 & 180 & - & 3.01 & 0.09 \\
\hline b4520 Lakeside & $3-74$ & 63.1 & 8.05 & 1035 & 92.6 & 189.35 & 5.5 & 0.14 & 16.5 & 0.405 & 1.36 & 304.6 & 33.5 & 131.5 & - & 4.18 & 0.11 \\
\hline ' 1200 Manzanita & $2-18-74$ & 80.0 & 7.5 & 1070 & 103.7 & 248 & 7.1 & 0.22 & 20.5 & 0.32 & 1.74 & 419 & 53 & 95 & - & 4.95 & 0.09 \\
\hline b1140 W. Peckham & $3-01-74$ & 85.0 & 7.78 & 1430 & 92.3 & 258.7 & 7.17 & 0.18 & 22.1 & 0.79 & 2.08 & 478.2 & 53 & 99 & - & 4.8 & 0.11 \\
\hline${ }^{b} 1160$ W. Peckham & $5-3-74$ & 85.0 & 8.35 & 1423 & 111 & 243.2 & 7.71 & 0.19 & 14.23 & 0.19 & 1.87 & 448.8 & 54 & 97.55 & - & 5.1 & 0.006 \\
\hline${ }^{b} 1150$ Sweetwater & $12-08-73$ & 78.0 & 8.20 & 1320 & 103.2 & 293 & 8.1 & - & 25 & 0.26 & 1.77 & 465.5 & 53 & 100.6 & - & 6.3 & 0.20 \\
\hline${ }^{b} 1204$ Sweetwater & $3-74$ & 90.0 & 7.65 & 1185 & 134.7 & 203 & 7.37 & 0.16 & 28.98 & 0.786 & 1.80 & 348.3 & 42.0 & 146.0 & - & 4.8 & 0.04 \\
\hline b2201 S. Virginia & $3-74$ & 42.0 & 7.95 & 942 & 57.8 & 175 & 5.96 & 0.12 & 15.8 & 1.49 & 0.75 & 258.3 & 31 & 131.0 & - & 0.75 & 0.13 \\
\hline${ }^{b} 1175$ Yates & $4-30-74$ & 89.9 & 8.29 & 1367 & 102 & 243.19 & 7.36 & 0.19 & 23.4 & 0.205 & 1.99 & 457 & 50 & 86.2 & - & 4.83 & 0.10 \\
\hline a4220 Swanson & $5-25-89$ & 87.7 & 8.08 & 1360 & 97.2 & 248 & 7.83 & - & 27.2 & 0.24 & - & 485 & 48.2 & 86.1 & - & - & 0.11 \\
\hline${ }^{`} 2707$ S. Virginia1 & $10-1-86$ & 52.0 & 8.30 & 1020 & - & 190 & 10.00 & - & 17.2 & 0.20 & 1.10 & 260.0 & 30 & 99.0 & - & 1.80 & 0.15 \\
\hline${ }^{`} 2707$ S. Virginia2 & $10-1-86$ & 52.8 & 8.20 & 1040 & - & 190 & 10.00 & - & 18.5 & 0.20 & 1.30 & 280.0 & 32 & 99.0 & - & 2.10 & 0.16 \\
\hline${ }^{a} 2135$ Richter & $9-13-89$ & 97.2 & 8.39 & 1360 & 114 & 257 & 11.70 & 0.26 & 31.2 & 0.15 & 2.0 & 499 & 48.8 & 77.5 & 1.8 & 4.94 & 0.13 \\
\hline a1680 Manzanita & $1-31-89$ & 75.0 & 8.36 & 1060 & 78.5 & 213 & 6.05 & - & 18.6 & 0.18 & - & 244.0 & 27.2 & 276.0 & 2.3 & - & 0.09 \\
\hline 3915 Nuttree & $1-31-89$ & 49.7 & 8.18 & 1410 & 115.0 & 269 & 8.21 & - & 26.4 & 0.18 & - & 489.0 & 49.7 & 90.5 & - & - & 0.12 \\
\hline d1301 Manzanita1 & $2-83$ & 90.0 & 8.37 & - & 120.0 & 259 & 11.20 & 0.26 & 24.6 & 0.21 & 2.25 & 449.0 & 48.0 & 106.0 & - & 5.57 & - \\
\hline '2600 Eastshore2 & $9-24-79$ & 58.8 & 7.86 & - & - & 184 & 9.00 & - & 16.0 & 1.00 & - & 287.0 & 31.0 & 120.0 & - & 1.21 & 0.07 \\
\hline ‘380 Brinkby1 & $6-30-86$ & 55.0 & 8.50 & - & 53.0 & 165 & 4.00 & - & 14.4 & 0.20 & 1.20 & 240.0 & 28.0 & 83.0 & 6.0 & 2.20 & 0.08 \\
\hline c380 Brinkby2 & $8-14-86$ & 55.0 & 8.70 & - & 66.0 & 175 & 3.50 & - & 12.6 & 0.10 & 1.30 & 260.0 & 30.0 & 77.0 & 14.0 & 2.30 & 0.12 \\
\hline${ }^{c}$ Warren1 & $1-4-88$ & 97.0 & 8.10 & - & 78.0 & 215 & 9.00 & - & 23.0 & 0.10 & 3.10 & 410.0 & 45.0 & 62.0 & - & 4.20 & 0.12 \\
\hline${ }^{c}$ Warren2 & $6-27-85$ & 98.0 & 8.30 & - & 110.0 & 254 & 12.00 & - & 27.0 & 0.10 & 2.20 & 422.0 & 49.0 & 69.0 & - & 5.00 & 0.13 \\
\hline 'Warren3 & $7-29-85$ & 93.3 & 8.70 & - & 110.0 & 310 & 9.50 & - & 24.0 & 1.20 & 2.70 & 540.0 & 58.0 & 90.0 & 14.0 & 5.10 & 0.10 \\
\hline
\end{tabular}


TABLE 3. CHEMICAL ANALYSES OF THERMAL WATERS FROM THE MOANA GEOTHERMAL AREA (cont.).

\begin{tabular}{|c|c|c|c|c|c|c|c|c|c|c|c|c|c|c|c|c|c|}
\hline Address & Date & $\begin{array}{c}\text { Temp } \\
{ }^{\circ} \mathrm{C}\end{array}$ & $\mathrm{pH}$ & $\begin{array}{c}\text { EC } \\
\mu \mathrm{mhos} / \mathrm{cm}\end{array}$ & $\begin{array}{l}\mathrm{SiO}_{2} \\
\mathrm{mg} / \mathrm{l}\end{array}$ & $\begin{array}{c}\mathrm{Na} \\
\mathrm{mg} / \mathrm{l}\end{array}$ & $\begin{array}{c}\mathrm{K} \\
\mathrm{mg} / \mathrm{l}\end{array}$ & $\begin{array}{c}\mathrm{Li} \\
\mathrm{mg} / \mathrm{l}\end{array}$ & $\begin{array}{c}\mathrm{Ca} \\
\mathrm{mg} / \mathrm{l}\end{array}$ & $\begin{array}{c}\mathrm{Mg} \\
\mathrm{mg} / \mathrm{l}\end{array}$ & $\begin{array}{c}\mathrm{B} \\
\mathrm{mg} / \mathrm{l}\end{array}$ & $\begin{array}{l}\mathrm{SO}_{4} \\
\mathrm{mg} / \mathrm{l}\end{array}$ & $\begin{array}{c}\mathrm{Cl} \\
\mathrm{mg} / \mathrm{l}\end{array}$ & $\begin{array}{c}\mathrm{HCO}_{3} \\
\mathrm{mg} / \mathrm{l}\end{array}$ & $\begin{array}{l}\mathrm{CO}_{3} \\
\mathrm{mg} / \mathrm{l}\end{array}$ & $\begin{array}{c}\mathrm{F} \\
\mathrm{mg} / \mathrm{l}\end{array}$ & $\begin{array}{c}\text { As } \\
\mathrm{mg} / \mathrm{l}\end{array}$ \\
\hline e2820 Moana & $9-15-83$ & 82.2 & 7.60 & - & 91.0 & 320 & 7.50 & - & 26.0 & 0.50 & - & 500.0 & 56.0 & 116.0 & - & 3.40 & 0.07 \\
\hline ¿690 Starlight & $2-11-80$ & 54.4 & 8.09 & - & - & 159 & 6.00 & - & 13.0 & - & - & 193.0 & 25.0 & 154.0 & - & 3.50 & 0.14 \\
\hline ¿4095 Garlan & $5-2-80$ & 48.3 & 8.34 & - & - & 154 & 8.00 & - & 12.0 & - & - & 173.0 & 21.0 & 149.0 & 8.0 & 3.84 & 0.13 \\
\hline e 4260 Warren & $7-27-80$ & 48.9 & 8.16 & - & - & 144 & 4.00 & - & 11.0 & - & - & 163.0 & 18.0 & 161.0 & - & 3.72 & 0.13 \\
\hline${ }^{e}$ Moana Pool & $2-5-85$ & 56.1 & 8.17 & 792 & 92.0 & 153 & 7.00 & - & 15.0 & - & 0.90 & 212.0 & 24.0 & 144.0 & - & 2.52 & 0.09 \\
\hline ¿4200 Garlan & $3-7-80$ & 43.3 & 8.12 & - & - & 134 & 6.00 & - & 10.0 & 1.00 & - & 129.0 & 10.0 & 188.0 & - & 3.87 & 0.15 \\
\hline${ }^{\mathrm{d}} 1100$ Moana & $2-83$ & 47.2 & 8.16 & - & 81.0 & 235 & 8.40 & 0.22 & 20.9 & 0.14 & 1.80 & 386.0 & 39.5 & 184.0 & - & 4.06 & - \\
\hline e3705 Lakeside & $6-04-86$ & 75.6 & 8.27 & 1384 & 107 & 252 & 7.0 & - & 25.0 & - & 1.8 & 474 & 48.0 & 102.0 & 5.0 & 4.8 & 0.11 \\
\hline '3835 Lakeside & $9-06-81$ & 70.0 & 8.16 & - & 128 & 280 & 7.0 & - & 25.0 & - & 2.0 & 489 & 49.0 & 90.0 & - & 5.24 & 0.12 \\
\hline d2040 Manzanita & $2-83$ & 95.0 & 8.22 & - & 113 & 257 & 12.2 & - & 24.7 & 0.10 & 2.55 & 459 & 47.0 & 93.0 & - & 5.15 & - \\
\hline${ }^{\mathrm{d}} 4400$ Plumas & $2-83$ & 92.2 & 8.29 & - & 110 & 241 & 11.6 & - & 25.2 & 0.07 & 2.24 & 459 & 46.5 & 114.0 & - & 5.36 & - \\
\hline d4000 Plumas & $7-83$ & 87.7 & 8.88 & - & 54.5 & 245 & 6.0 & - & 16.7 & 0.01 & 2.10 & 445 & 30.0 & 133 & - & 4.4 & - \\
\hline ¿3850 Plumas & $9-6-80$ & 71.3 & 7.94 & - & - & 263 & 7.0 & - & 28 & 2.0 & - & 494 & 47.0 & 98 & - & 4.94 & 0.165 \\
\hline 'Old Moana Pool & $6-14-79$ & 51.7 & 7.96 & 813 & 77.5 & 153 & 6.8 & - & 17.5 & 1.20 & - & 232 & 25.0 & 140 & - & - & - \\
\hline
\end{tabular}

- (data not available)

Temp ${ }^{1}$ - temperatures obtained from well logs.

Sources: a Desert Research Institute, 1989

${ }^{b}$ Scheibach, 1975

c Sierra Environmental Monitoring

d Flynn and Ghusn, 1984

e Nevada State Health Laboratory, Nevada Division of Health

' William E. Nork, Inc. 
cooler waters of a different origin. The relative degree of mixing in the geothermal aquifer can be identified because of the different chemical makeup of the thermal and nonthermal waters of the area. The relationships between temperature and concentrations of these elements supports the mixing concept.

The relationship between temperature and concentration was examined for the soluble elements: boron, chloride, fluoride, lithium, arsenic and for bicarbonate, the most abundant constituent in nonthermal waters of the area. Figures 32 through 37 show the relationship between maximum observed temperature and the concentration of these chemical constituents of boron, chloride, fluoride, lithium, arsenic and bicarbonate, respectively, in geothermal wells of the resource area. Examples of nonthermal waters from the southern boundary of the Moana area are included in the plots for comparison. A linear least squares fit of each data set illustrates the general trend of the data. The least squares fit line is considered an approximate mixing trend in most of the plots.

The chemical constituents boron, chloride, fluoride, and lithium (Figures 32 through 35 , respectively) all show a positive correlation between concentration and temperature. Generally, the higher the temperature, the higher the concentration of each constituent. The best correlation coefficient values, $\mathbf{R}$, of temperature and concentration are for the elements boron and chloride. The nonthermal waters plot reasonably well on the mixing trend line.

The trend between arsenic concentration and temperature (Figure 36) is relatively flat. The scatter of the data and low correlation coefficient suggest either a poor correlation in the data or that arsenic was not conserved.

The concentration of bicarbonate in Moana area waters is inversely proportional to temperature (Figure 37). Generally, higher temperature wells have lower concentrations of bicarbonate. The nonthermal water samples do not fall on the least squares fit line. This suggests that the increase in bicarbonate content as the water temperature decreases may not be entirely a function of mixing with nonthermal waters. The nonconservative behavior of bicarbonate makes alternative methods of analysis necessary.

Several geochemical modeling simulations were run using WATEQ DR (Bohm and Jacobson, 1981). Simulations were run for 11 different water samples, with temperatures ranging from $50^{\circ}$ to $98^{\circ} \mathrm{C}$. Although this model has only been verified for temperatures less than $75^{\circ} \mathrm{C}$, it is still useful for understanding the general chemical equilibria of the thermal waters. The simulations show that the thermal waters are at saturation with respect to calcite. The solubility of calcite increases with decreasing temperature. However, the thermal waters remain at saturation even in the lower temperature waters of the resource area. Calcite solubility is a control on the bicarbonate content of the thermal waters, which suggests that bicarbonate concentration is sensitive to any change in temperature. 


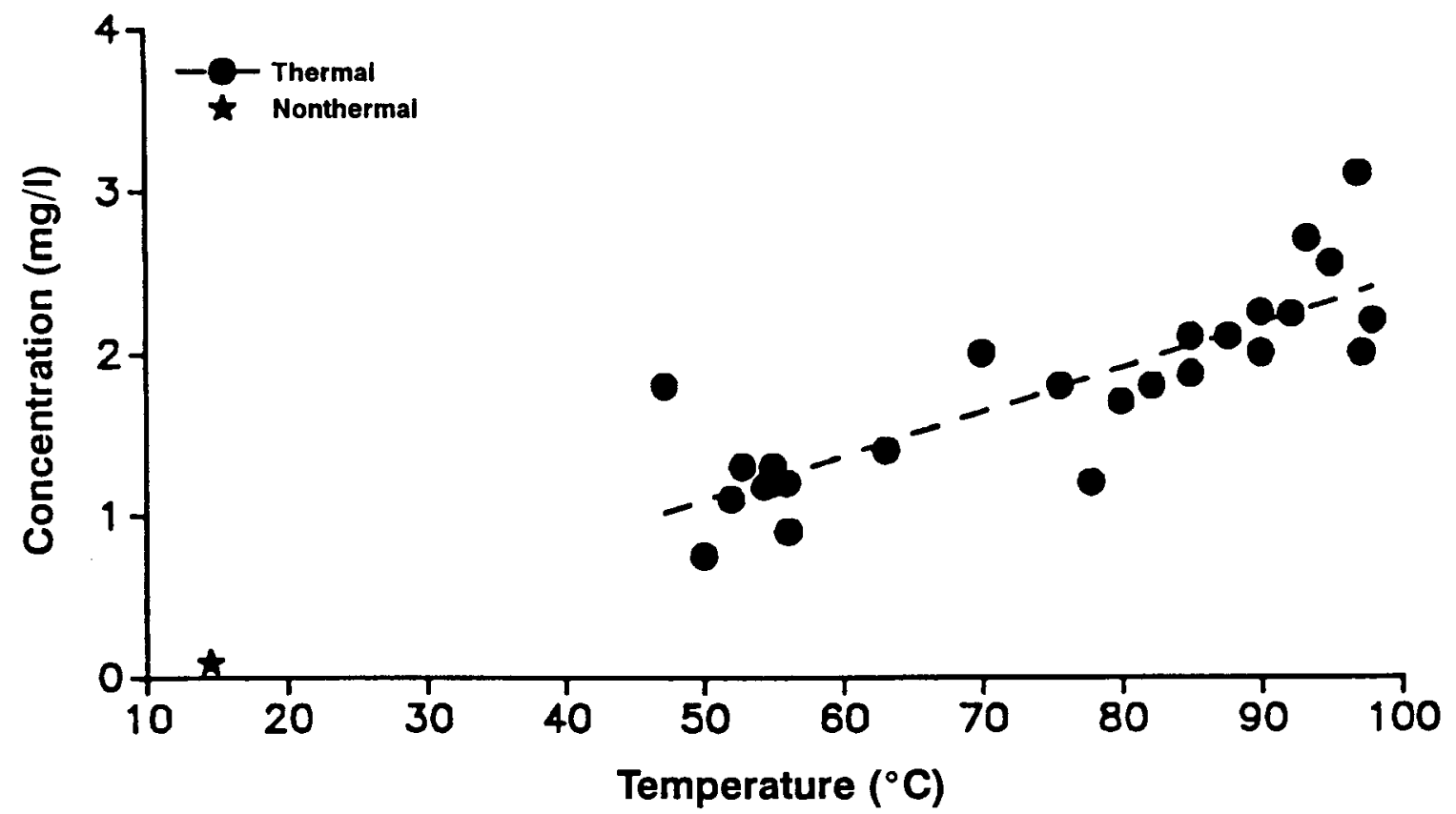

FIGURE 32. Boron Concentration with Temperature for Groundwater from the Moana Geothermal Area $(\mathrm{R}=0.837791)$.

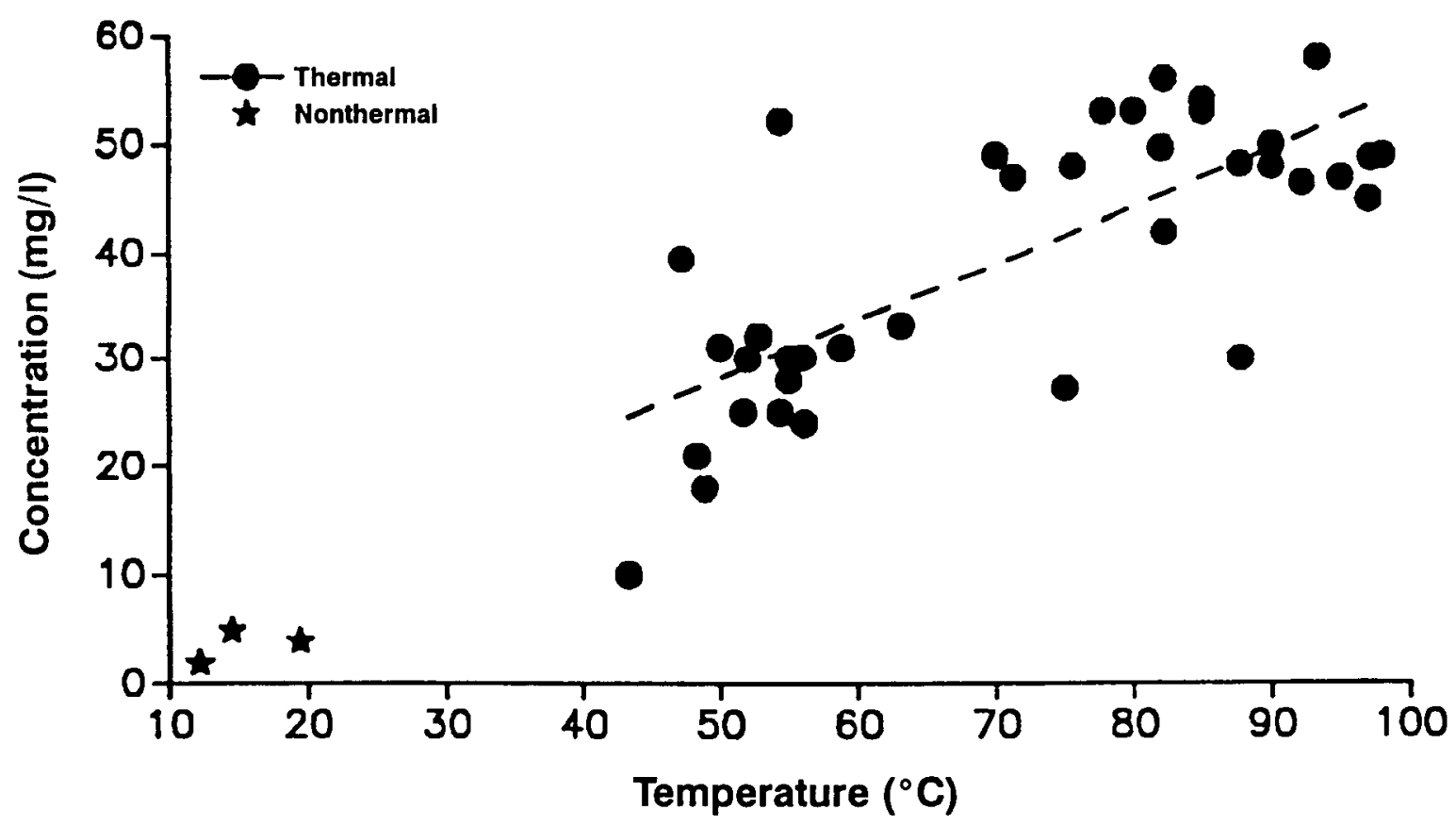

FIGURE 33. Chloride Concentration with Temperature for Groundwater from the Moana Geothermal Area $(\mathrm{R}=0.755773)$. 


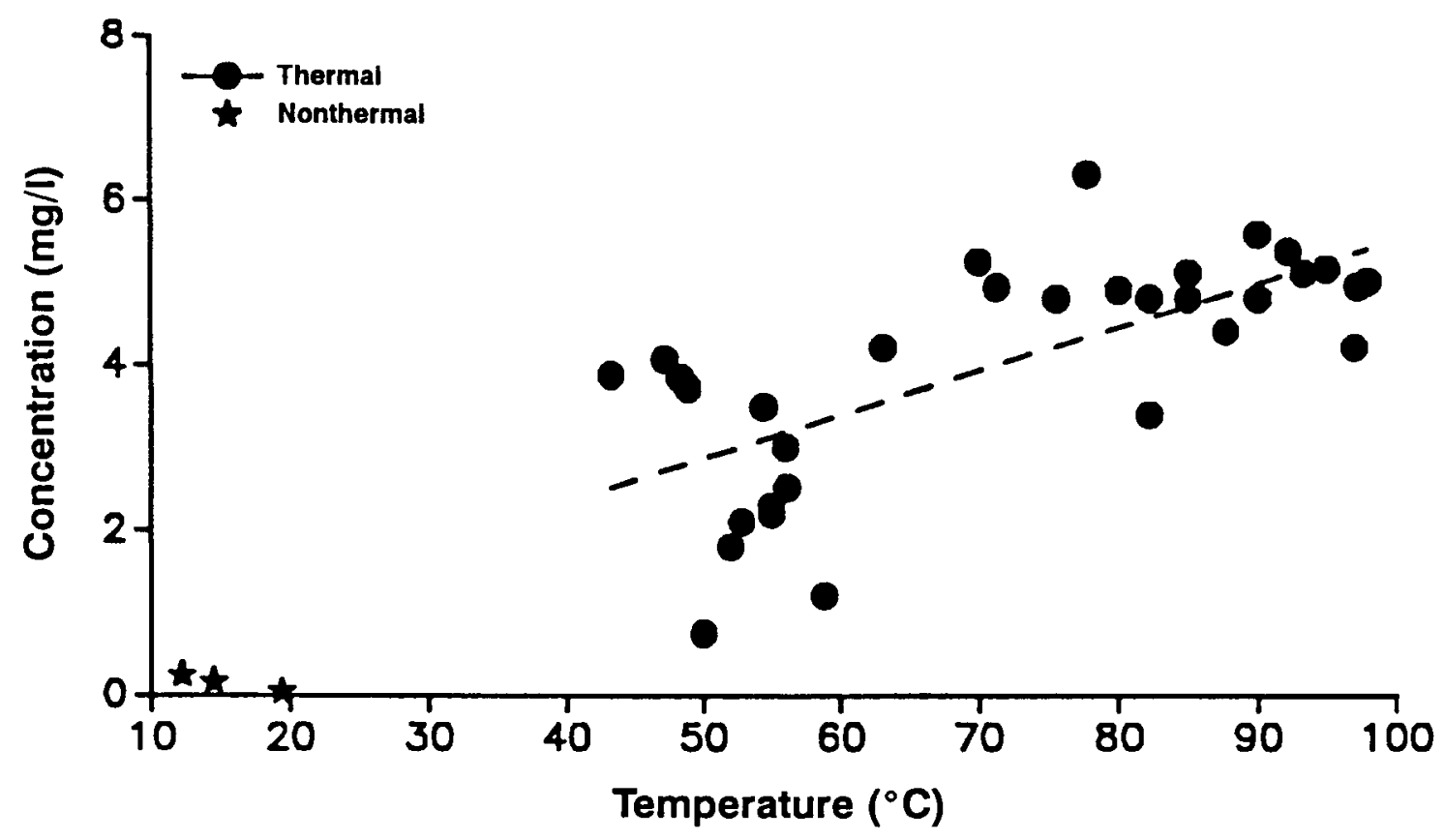

FIGURE 34. Fluoride Concentration with Temperature for Groundwater from the Moana Geothermal Area $(R=0.696954)$.

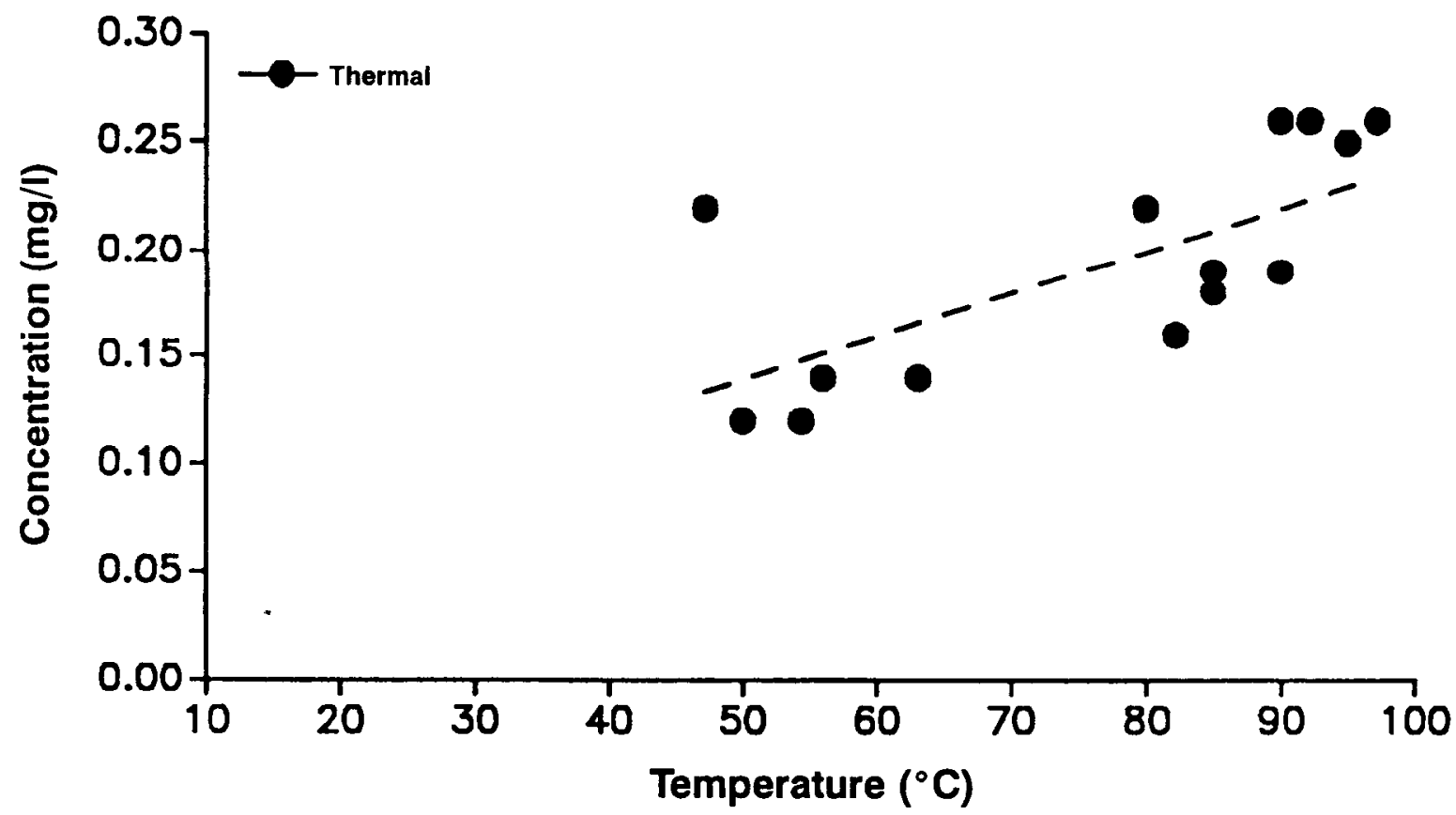

FIGURE 35. Lithium Concentration with Temperature for Groundwater from the Moana Geothermal Area $(\mathrm{R}=0.698907)$. 


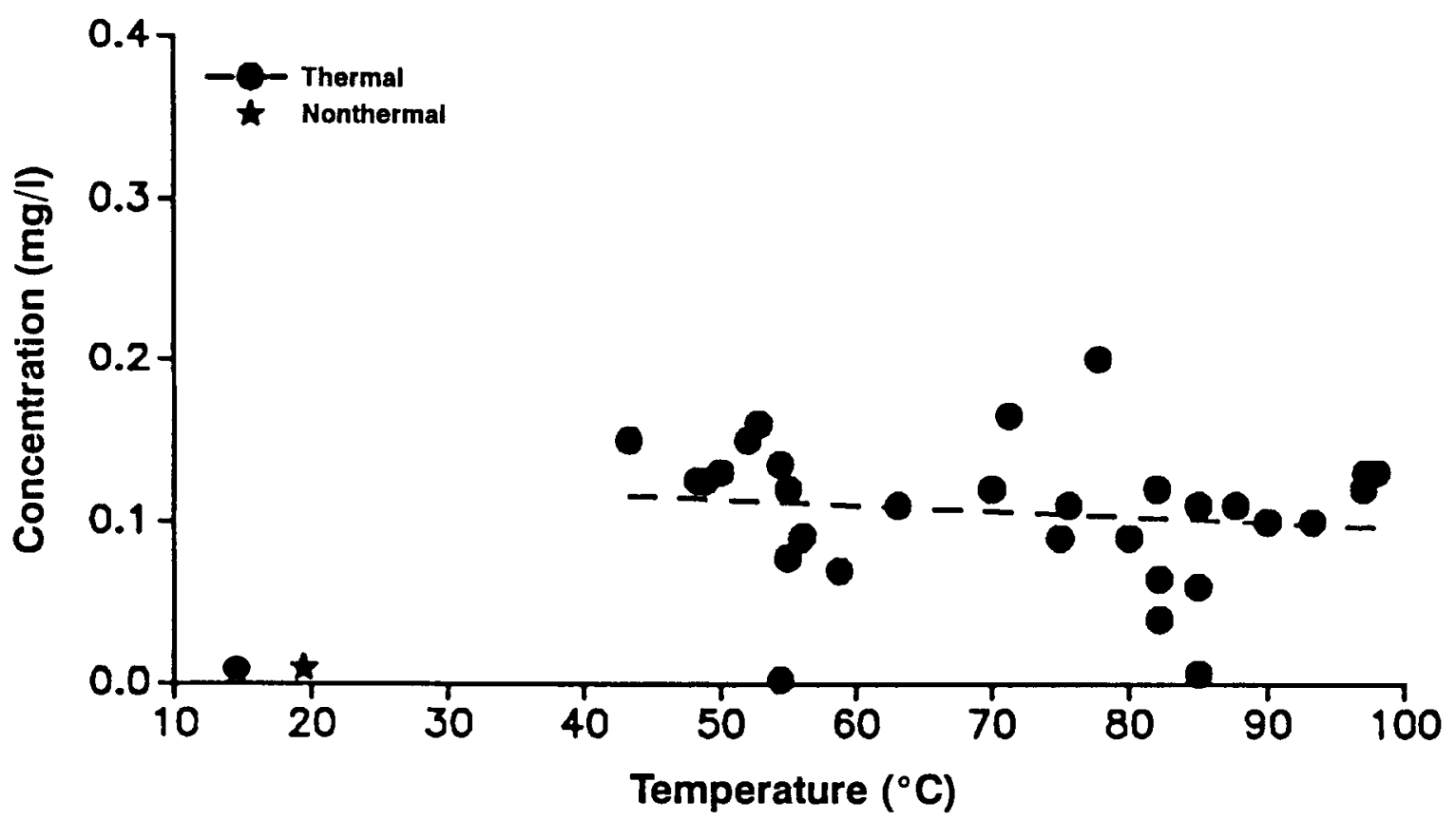

FIGURE 36. Arsenic Concentration with Temperature for Groundwater from the Moana Geothermal Area $(\mathrm{R}=-0.142164)$.

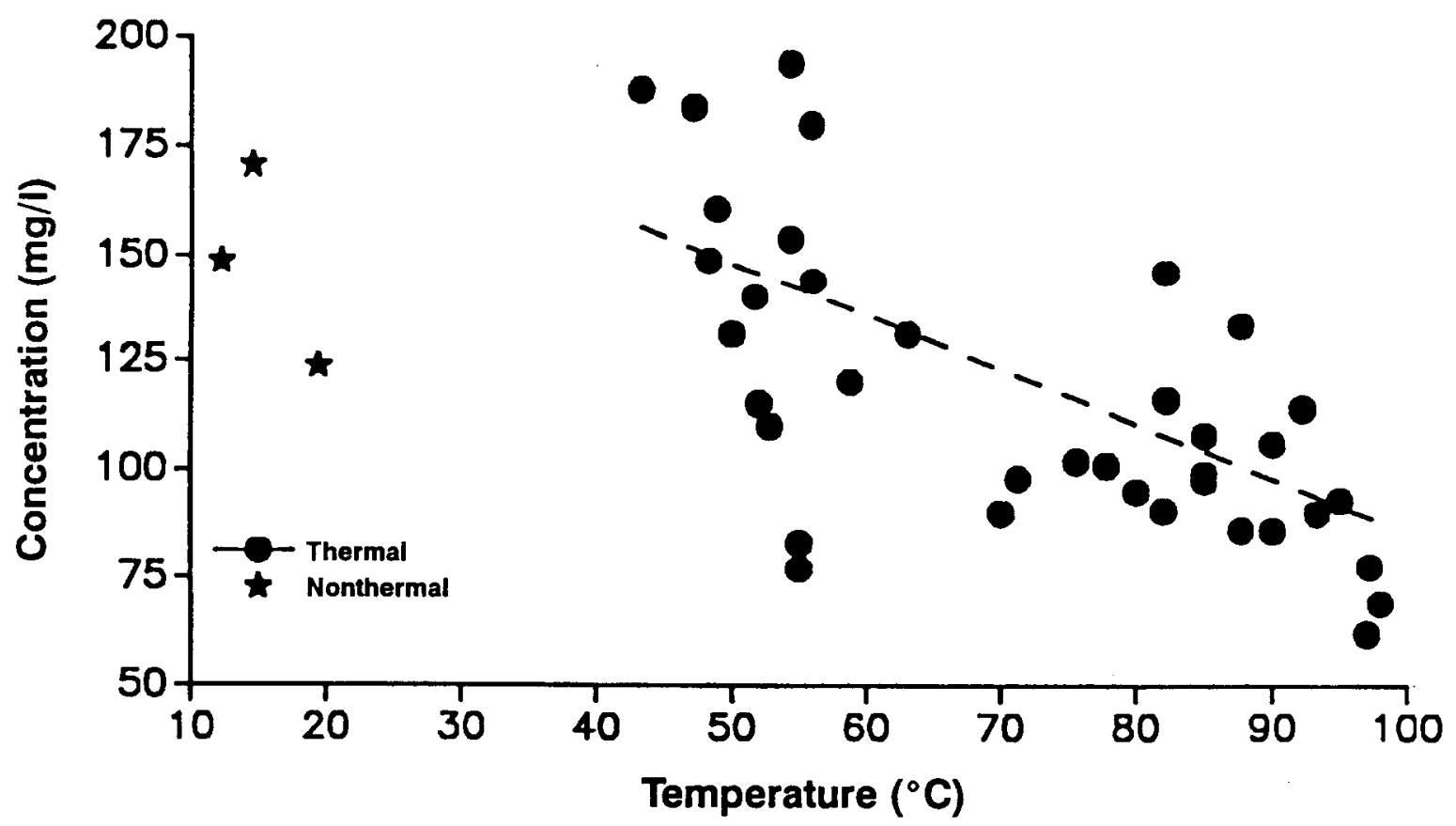

FIGURE 37. Bicarbonate Concentration with Temperature for Groundwater from the Moana Geothermal Area $(R=-0.519468)$. 
An alternative source of the bicarbonate is the reaction of dissolved carbon dioxide with feldspars to produce clays within the geothermal aquifer. Several pieces of evidence support this mechanism as a source of bicarbonate. The andesites and dacites of the Kate Peak Formation (host rock of the geothermal aquifer) are chiefly plagioclase feldspars, and smectite clays compose a large portion of the geothermal aquifer materials (Flynn and Ghusn, 1984). The activities calculated by WATEQ DR for the sodiumhydrogen ratio and silica fall near the stability field boundary for albite (a plagioclase feldspar) and smectite. Finally, partial pressures of carbon dioxide decline as temperatures of the thermal waters decline. This suggests that the dissolved carbon dioxide is consumed in some type of reaction. The increase in bicarbonate concentration is probably a function of both mixing and rock-water reactions within the geothermal aquifer. Whatever the mechanisms, bicarbonate content increases with decreasing temperature in the thermal waters, as shown in Figure 36. This increase of bicarbonate content with decreasing temperature is real despite the large scatter in the data, which will be discussed in detail later.

The expression of ion ratios is also useful in identifying changes in the geothermal aquifer. Figures 38 and 39 examine the relationship between the chloride-boron ratio and bicarbonate-chloride ratio and temperature, respectively. Both ratios have a negative correlation with temperature, the higher the ratio the lower the temperature. The bicarbonate-chloride ratio is particularly useful in identifying thermal changes in the geothermal aquifer. Bicarbonate and chloride concentrations have contradictory relationships with temperature. Changes in temperature will be reflected as a decrease in one constituent and an increase in the other. Therefore, meaningful changes in the concentration of each constituent are amplified when examining the ratio.

It is important to keep in mind that these chemistry data were assembled from many different sources. This is believed to contribute to the scatter of the data and the low correlation coefficients in some of the plots. As a test, the bicarbonate and chloride data from 11 wells included in the 1989 DRI investigation were plotted against the maximum observed temperatures in the wells. Figure 40 presents these datasets and correlation coefficients. There is a significant increase in the correlation coefficient when only DRI measured data are included, indicating the need for consistent data.

All of these figures illustrate the thermal effect of mixing between: 1) dilute, bicarbonate-dominated, nonthermal water; and 2) chloride, boron, fluoride, and lithiumenriched thermal water in the Moana geothermal aquifer. Now that the general relationships between these chemical constituents and temperature have been defined, they can be used to explore changing thermal conditions in the geothermal aquifer.

Assuming steady-state aquifer conditions, the concentration of soluble elements in geothermal waters should be constant at any given location. Variations at a given location in the concentration of these elements, chloride, boron, fluoride and lithium, indicate a change in the rate of mixing between nonthermal and thermal waters. Tempera- 


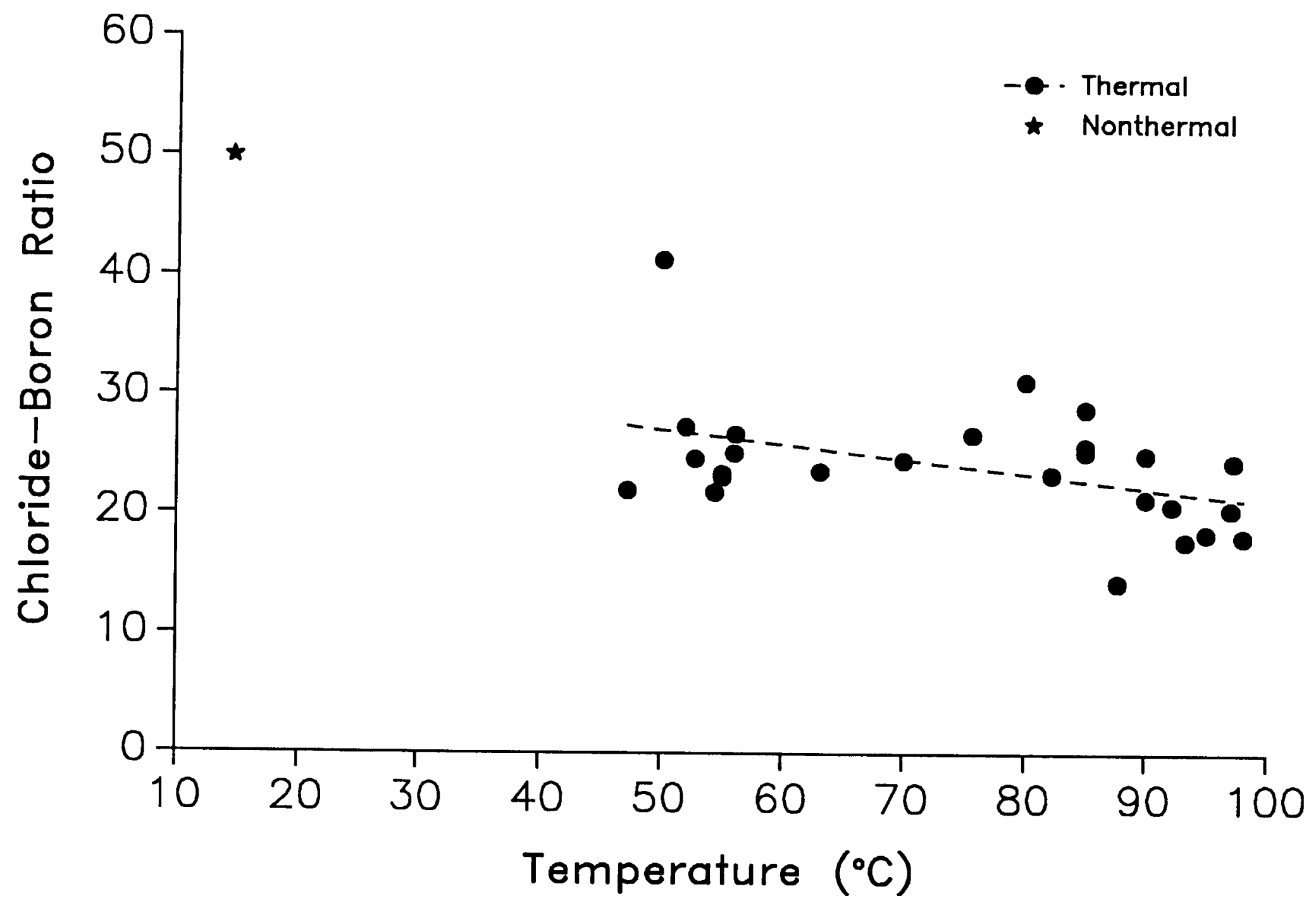

FIGURE 38. Chloride-Boron Ratio with Temperature for Groundwater from the Moana Geothermal Area $(\mathrm{R}=-0.428400)$. 


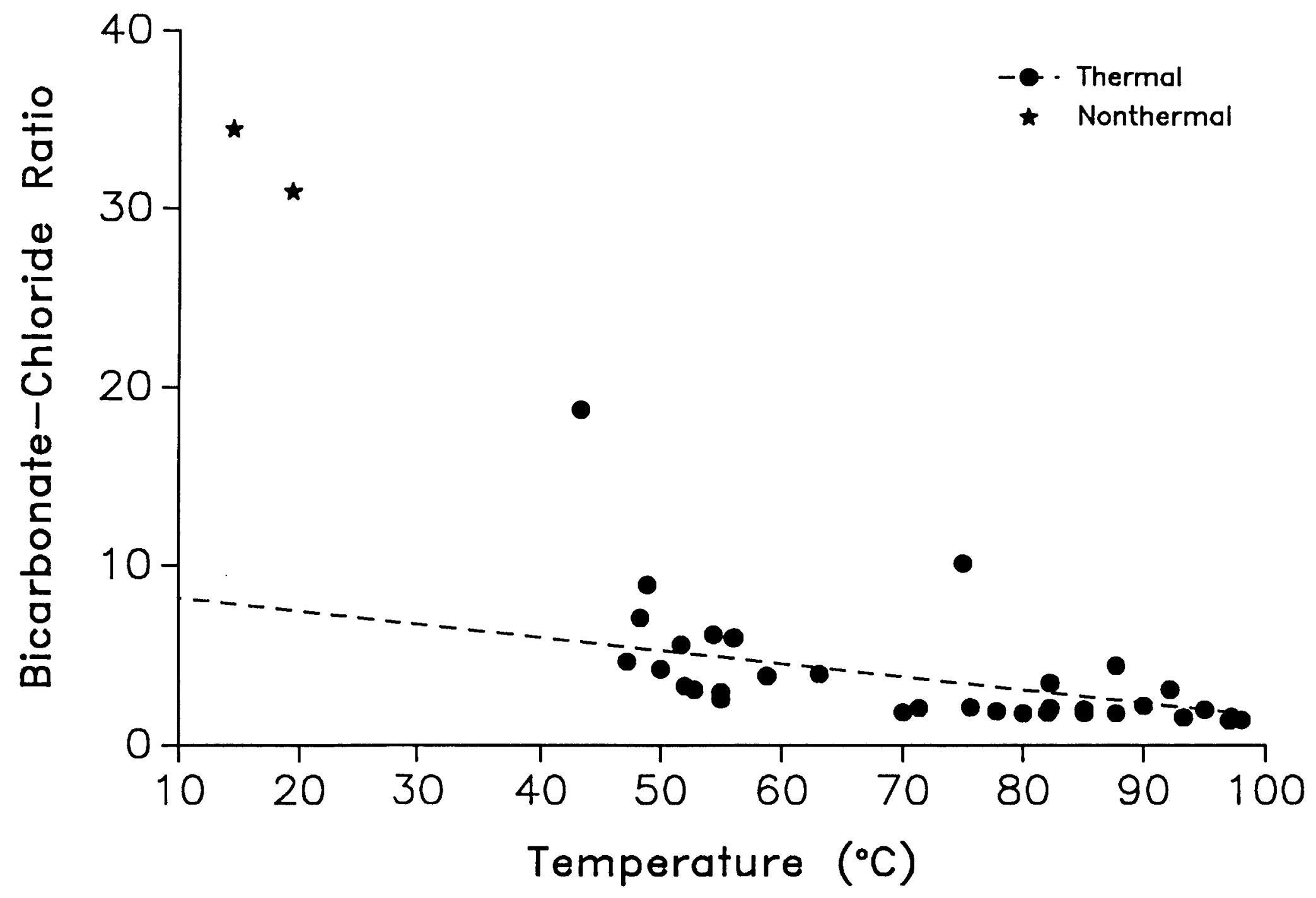

FIGURE 39. Bicarbonate-Chloride Ratio with Temperature for Groundwater from the Moana Geothermal Area $(\mathrm{R}=-0.444135)$. 


\section{Bicarbonate Concentration versus Temperature}

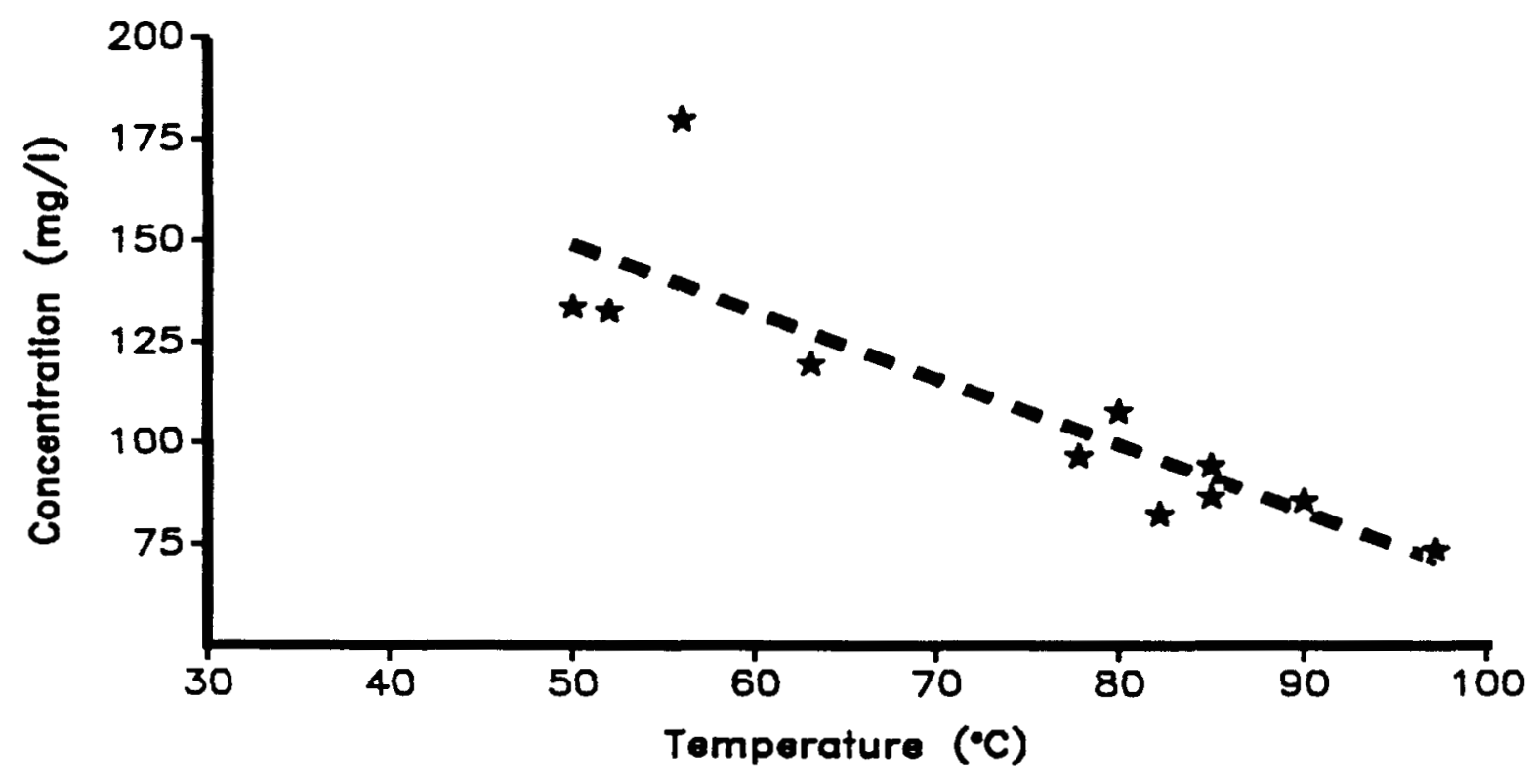

Chloride Concentration versus Temperature

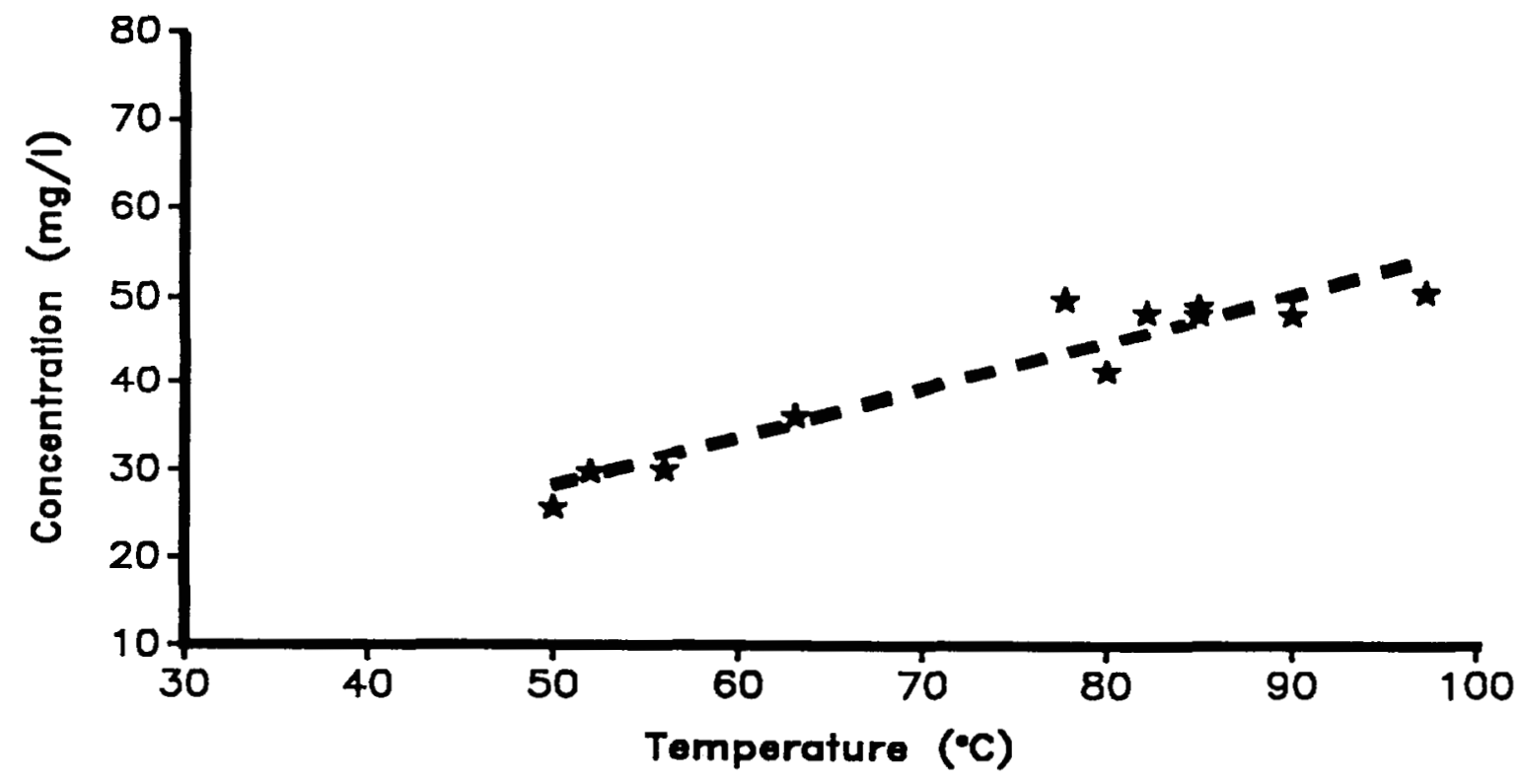

FIGURE 40. Bicarbonate and Chloride Concentrations with Temperature for Groundwater Samples Collected by DRI for this Project from the Moana Geothermal Area $(\mathrm{R}=-0.86435$ and $\mathrm{R}=0.94875$ for bicarbonate and chloride with temperature, respectively). 
ture in the Moana geothermal aquifer is a function of the degree of mixing. Therefore, variations in the concentration of these elements can be used as a qualitative measure of temperature change.

Boron and chloride concentrations have the best correlation with temperature of the soluble elements (see Figures 32 and 33, respectively). An increase or decrease in the concentration of these elements should correspond to an increase or decrease in temperature. The relationship of bicarbonate to temperature is the opposite of chloride to temperature. The bicarbonate-chloride ratio emphasizes opposite changes in the concentration of each constituent. Similar changes, i.e., both increase or decrease, in the concentration of each constituent will be filtered out by examining the ratio. Increases in the ratio correspond to decreasing temperatures and decreases in the ratio correspond to increasing temperatures (see Figure 39). Boron, chloride, and the bicarbonate-chloride ratio are considered qualitative temperature analogs and are used to examine thermal changes in the geothermal aquifer.

\section{TEMPORAL VARIATION}

Seasonal and long-term variations of water chemistry were investigated in the Moana geothermal area. Seasonal variations were examined to determine if pumping rate has an effect on the mixing process and, therefore, temperature in the aquifer. Long-term variations were examined to investigate the thermal response to decreasing aquifer pressures in the resource area.

\section{Seasonal Variation}

Seasonal variation was examined for two commercial wells in the Moana resource area. The wells were the Virginia Lake Townhouses production well at 2600 Eastshore Drive and the Sierra Geothermal production well at 2135 Richter Circle. The wells were sampled on an approximately monthly basis between January 1989 and September 1989. The sampling program goal was to determine if changes in the rate of pumpage between heating and nonheating seasons have an effect on temperature. The Virginia Lake Townhouses and Sierra Geothermal wells have peak heating season discharges of 300 and 50 gallons per minute (gpm), respectively (NDEP, personal communication, 1989). The nonheating period discharge is unknown, but is probably on the order of 10 gpm at both locations. Table 4 presents the chemical analyses for the water samples collected at these sites.

Figures 41 through 44 graphically examine chloride concentration versus time and bicarbonate-chloride ratios versus time for the Virginia Lake Townhouses (2600 Eastshore) and Sierra Geothermal (2135 Richter Circle), respectively. A linear least squares fit is applied to each dataset. The figures show that chloride concentrations and bicarbonate-chloride ratios are constant at both locations, at least within the analytical error, during the sampling period. These data suggest that the rate of mixing between thermal 
TABLE 4. COMPARISON OF SEASONAL CHEMICAL ANALYSES IN GEOTHERMAL WATERS.

\begin{tabular}{|c|c|c|c|c|c|c|c|c|c|c|c|c|c|c|c|c|c|}
\hline $\begin{array}{l}\text { Address } \\
\text { Location }^{2}\end{array}$ & Date & $\begin{array}{c}{ }^{\circ} \mathrm{C} \\
{ }^{\circ} \mathrm{C}\end{array}$ & $\mathrm{pH}$ & $\begin{array}{c}\text { EC } \\
\mu \mathrm{mhos} / \mathrm{cm}\end{array}$ & $\begin{array}{l}\mathrm{SiO}_{2} \\
\mathrm{mg} / 1\end{array}$ & $\begin{array}{l}\mathrm{Na} \\
\mathrm{mg} / \mathrm{l}\end{array}$ & $\underset{\mathrm{mg} / \mathrm{l}}{\mathrm{K}}$ & $\begin{array}{c}\mathrm{Li} \\
\mathrm{mg} / \mathrm{l}\end{array}$ & $\begin{array}{c}\mathrm{Ca} \\
\mathrm{mg} / \mathrm{l}\end{array}$ & $\begin{array}{c}\mathrm{Mg} \\
\mathrm{mg} / \mathrm{l}\end{array}$ & $\begin{array}{c}\mathrm{B} \\
\mathrm{mg} / 1\end{array}$ & $\begin{array}{l}\mathrm{SO}_{4} \\
\mathrm{mg} / \mathrm{l}\end{array}$ & $\begin{array}{c}\mathrm{Cl} \\
\mathrm{mg} / \mathrm{l}\end{array}$ & $\begin{array}{c}\mathrm{HCO}_{3} \\
\mathrm{mg} / 1\end{array}$ & $\begin{array}{l}\mathrm{CO}_{3} \\
\mathrm{mg} / \mathrm{l}\end{array}$ & $\underset{\mathrm{mg} / \mathrm{l}}{\mathrm{F}}$ & $\begin{array}{c}\text { As } \\
\mathrm{mg} / \mathrm{l}\end{array}$ \\
\hline 2600 Eastshore 1 & $1-05-89$ & 56.0 & 8.25 & 1030 & 94.8 & 194 & 9.32 & - & 21.8 & 1.20 & - & 293 & 31.1 & 173 & - & - & 0.11 \\
\hline \multirow[t]{6}{*}{ T19N R19E 24BCD } & $2-13-89$ & - & 8.28 & 1030 & 93.6 & 191 & 9.78 & - & 20.8 & 1.01 & - & 293 & 31.4 & 174 & - & - & 0.09 \\
\hline & $3-28-89$ & - & 8.27 & 1020 & 92.6 & 191 & 9.64 & - & 20.8 & 0.98 & - & 277 & 30.5 & 175 & - & - & 0.11 \\
\hline & $4-27-89$ & - & 8.34 & 1020 & 92.8 & 190 & 9.93 & - & 19.6 & 1.31 & - & 294 & 31.1 & 171 & 1.2 & - & 0.11 \\
\hline & $5-25-89$ & - & 8.29 & 1040 & 93.3 & 190 & 9.77 & - & 20.5 & 0.94 & - & 309 & 31.0 & 173 & - & - & 0.11 \\
\hline & $6-29-89$ & - & 8.36 & 1010 & 93 & 189 & 9.30 & - & 20.3 & 0.98 & - & 279 & 30.3 & 174 & 2.5 & - & 0.10 \\
\hline & $9-27-89$ & - & 8.28 & 971 & 93.7 & 189 & 9.42 & 0.14 & 20.3 & 0.98 & 1.2 & 281 & 30.1 & 180 & - & 3.01 & 0.09 \\
\hline 2135 Richter & $1-05-89$ & 97.2 & 8.34 & 1390 & 112 & 250 & 11.3 & - & 30.8 & 0.49 & - & 489 & 49.1 & 78.2 & 1.1 & - & 0.15 \\
\hline \multirow[t]{6}{*}{ T19N R19E 27A } & $2-13-89$ & - & 8.42 & 1410 & 113 & 258 & 12.0 & - & 30.3 & 0.15 & - & 496 & 49.2 & 77.4 & 2.1 & - & 0.15 \\
\hline & $3-30-89$ & - & 8.35 & 1410 & 113 & 262 & 11.0 & - & 30.3 & 0.14 & - & 497 & 49.2 & 78.9 & 1.0 & - & 0.13 \\
\hline & $4-27-89$ & - & 8.27 & 1410 & 113 & 260 & 11.6 & - & 30.3 & 0.16 & - & 500 & 49.3 & 81.0 & - & - & 0.15 \\
\hline & $6-29-89$ & - & 8.40 & 1410 & 111 & 261 & 11.8 & - & 31.2 & 0.13 & - & 493 & 50.2 & 75.7 & 2.8 & - & 0.12 \\
\hline & $7-26-89$ & - & 8.42 & 1390 & 112 & 260 & 11.8 & - & 31.2 & 0.14 & - & 483 & 50.7 & 73.9 & 3.2 & - & 0.12 \\
\hline & $9-13-89$ & - & 8.39 & 1360 & 114 & 257 & 11.7 & 0.26 & 31.2 & 0.15 & 2.0 & 499 & 48.8 & 77.5 & 1.8 & 4.94 & 0.13 \\
\hline
\end{tabular}

Temp $p^{1}$ - temperatures obtained from well logs.

Location ${ }^{2}$ - based on Township, Range, and Section

- (data not available) 


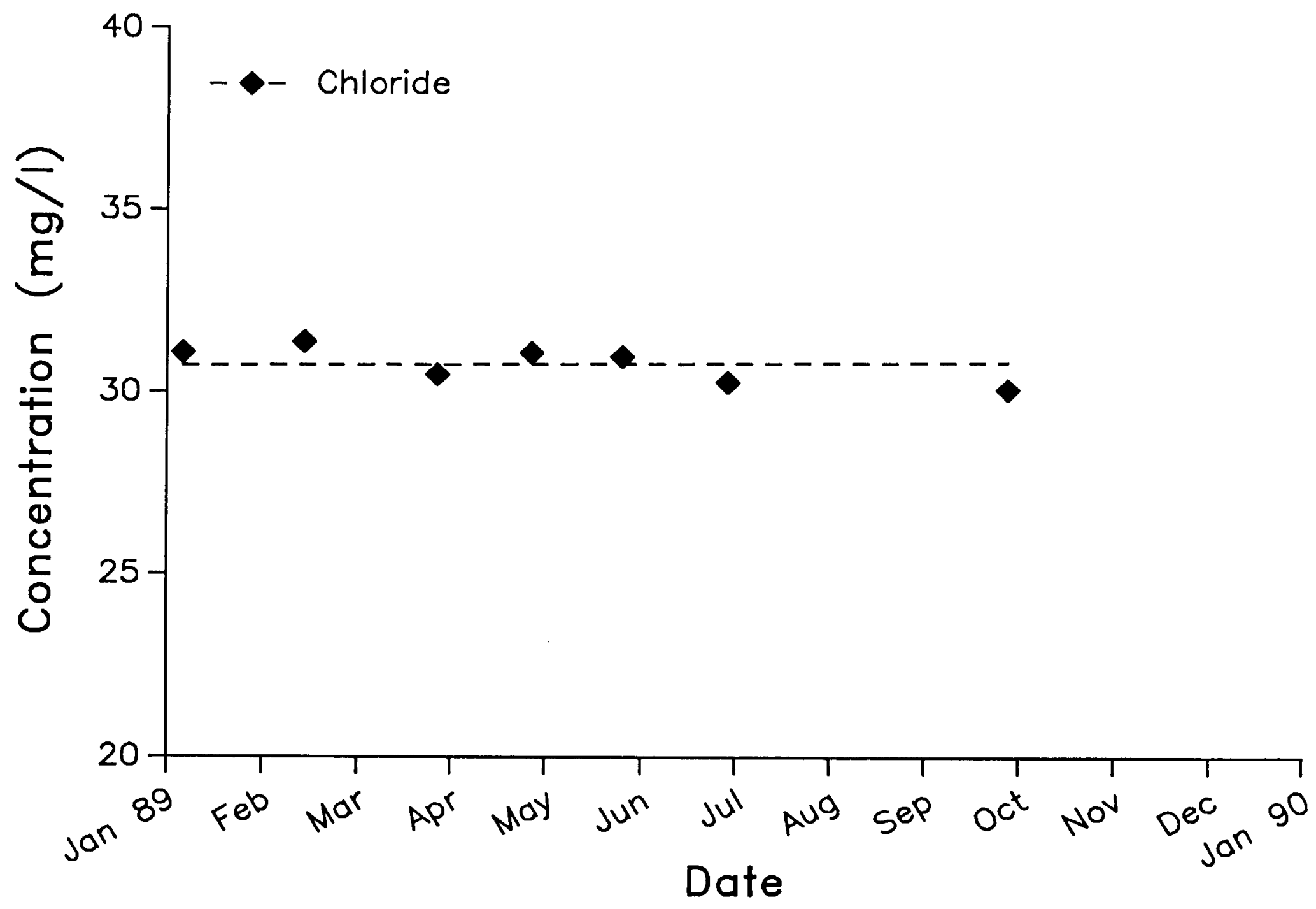

FIGURE 41. Chloride Concentration with Time for the Virginia Lake Townhouse Geothermal Well (2600 Eastshore). 


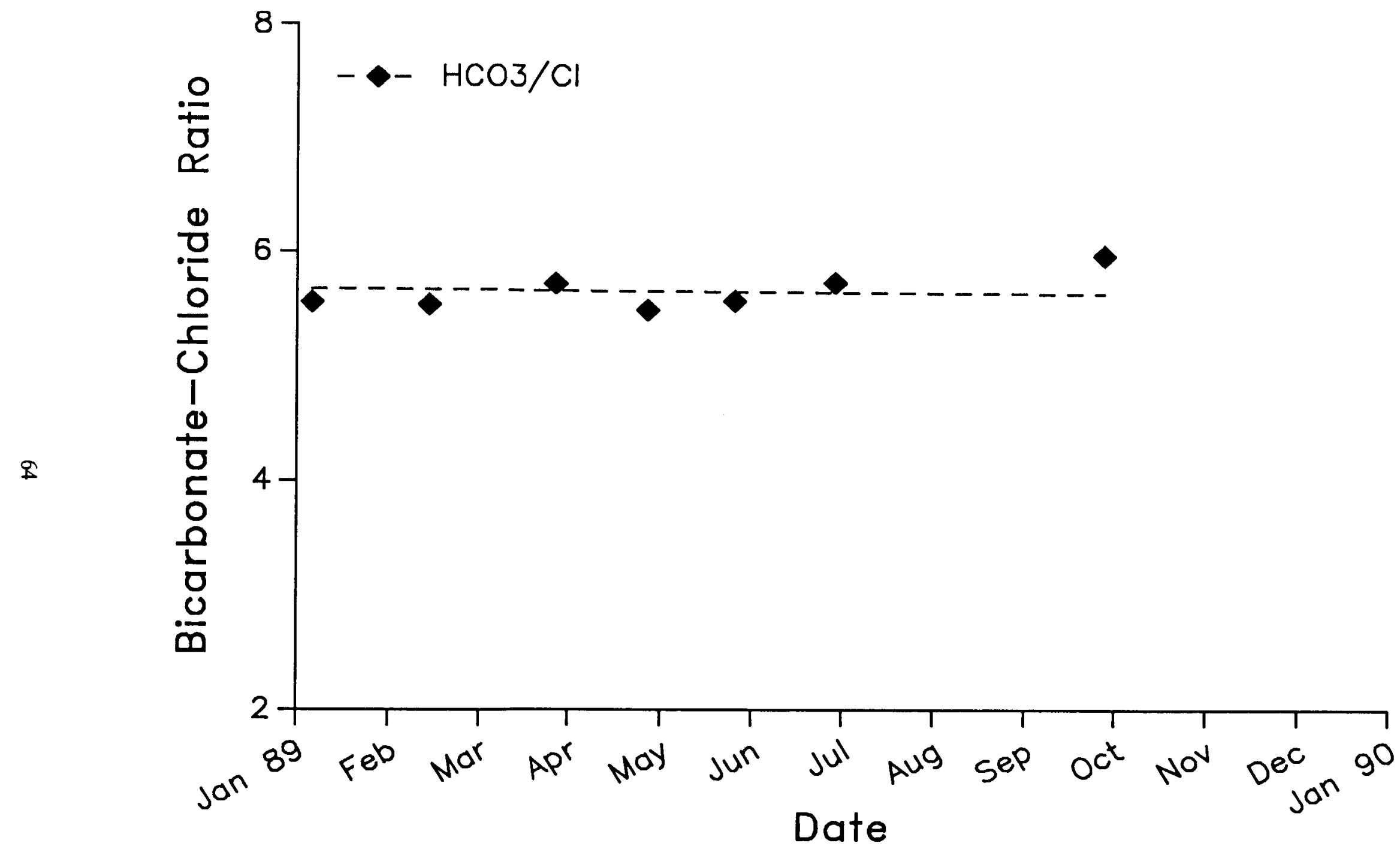

FIGURE 42. Bicarbonate-Chloride Ratio with Time for the Virginia Lake Townhouse Geothermal Well (2600 Eastshore). 


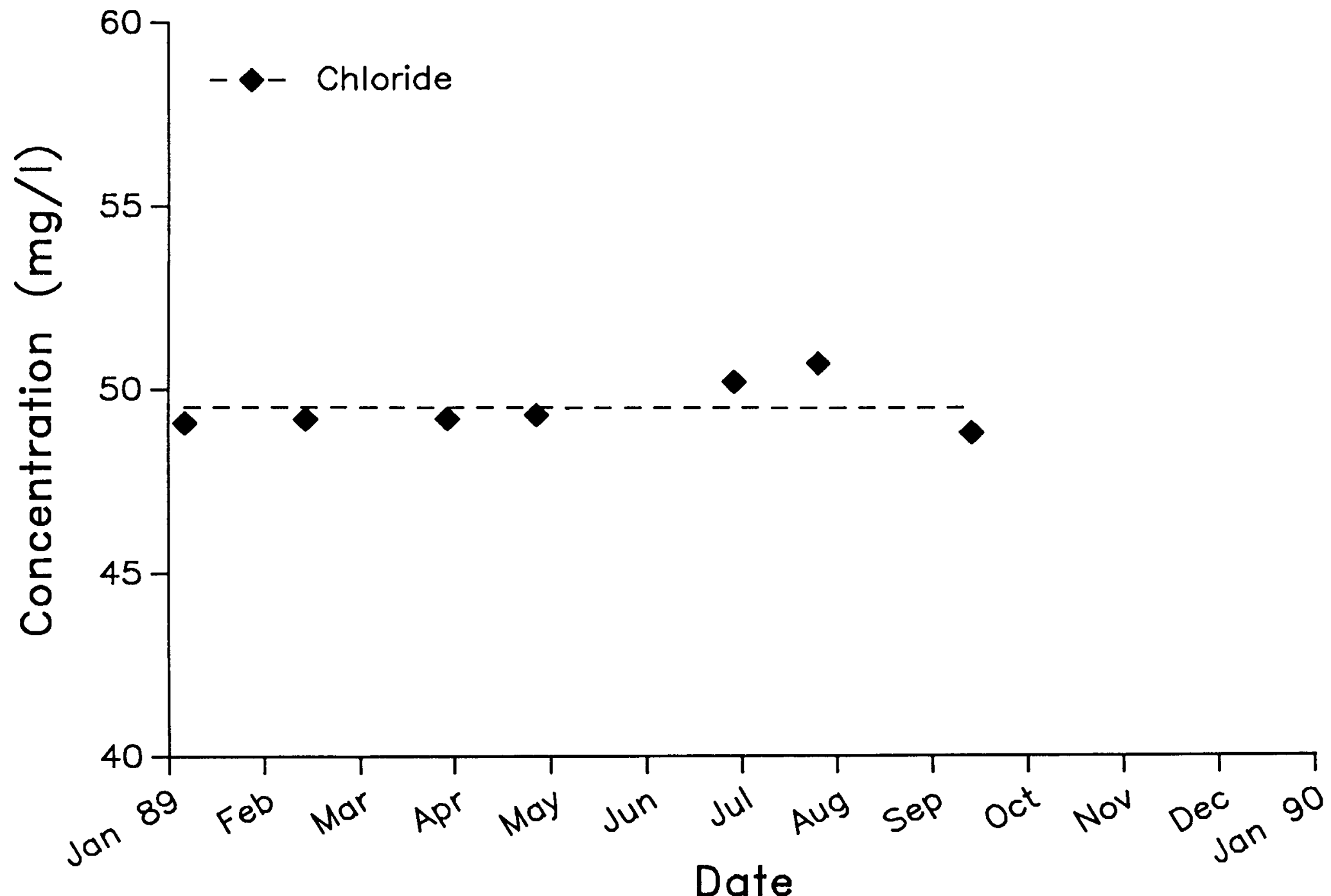

FIGURE 43. Chloride Concentration with Time for the Sierra Geothermal Well (2135 Richter). 


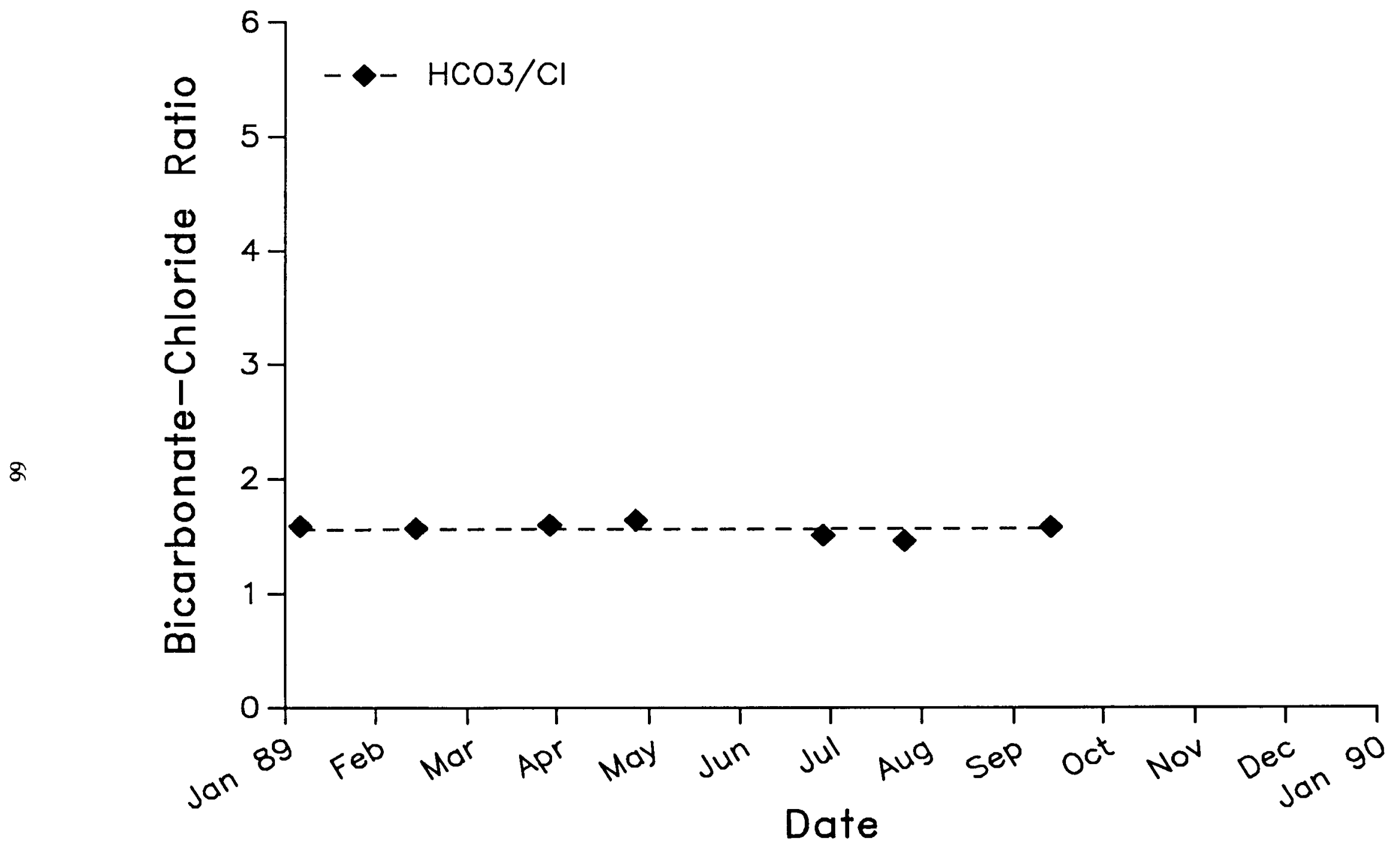

FIGURE 44. Bicarbonate-Chloride Ratio with Time for the Sierra Geothermal Well (2135 Richter). 
and nonthermal waters is seasonally constant and independent of discharge rate at the two sample locations. Therefore, changes in the rate of pumpage do not appear to produce mixing-induced temperature changes.

\section{Long-Term Variation}

Long-term variations in geothermal waters of the Moana resource area were examined by resampling 10 of 12 locations sampled by Scheibach (1975) during his 1974 study. Scheibach's chemistry data is believed to represent aquifer geochemical conditions in a pre- or low-stress environment. The 1989 Desert Research Institute sample data is believed to be representative of the current stressed conditions (lowered aquifer pressures) in the geothermal aquifer. Table 5 presents the 1974 and 1989 chemical analyses for the 10 wells and Figure 45 shows the locations of the wells labled from A to J.

The chemical data are graphically examined by plotting boron and chloride concentrations versus the bicarbonate-chloride ratios for the 10 locations sampled. Changes in the composition of the waters are considered significant when both variables in the plot exhibit a change.

Figures 46 and 47 present the bicarbonate-chloride ratio versus chloride concentration and boron concentration relationships, respectively, for Well B, Well I, Well C and Well G. Solid symbols represent the 1989 sample group and hollow symbols represent the 1974 sample group. These four wells all exhibit significant changes in composition since the 1974 sampling event.

Three of the wells, Well B, Well I and Well G, show an increase in thermal water components in the samples. This is expressed as an increase in chloride and boron content and a corresponding decrease in the bicarbonate-chloride ratio. These data indicate that the nonthermal water contribution to the geothermal aquifer has decreased in the vicinity of these wells. The results suggest that well temperatures were hotter during the 1989 sampling event than during the 1974 sampling event.

The well at Well C shows a decrease in thermal water components since the 1974 sampling event. This change is expressed by a decrease in chloride and boron content and a corresponding increase in the bicarbonate-chloride ratio. The owner of this well has complained of decreasing heat output. The water chemistry data support his complaints and suggest that temperatures are declining in the well. This decrease in temperature is also observed in the measured temperature data given in Table 5.

Figures 48 and 49 illustrate the bicarbonate-chloride ratio versus chloride concentration and boron concentration relationships, respectively, for Well $\mathrm{H}$, Well $\mathrm{F}$ and Well $\mathrm{J}$. Well $\mathrm{H}$ was the only one of the three to show significant chemical changes. Chloride concentration decreased, boron concentration was approximately the same, only showing a slight increase, and the bicarbonate-chloride ratio increased. The chloride data and bicarbonate-chloride ratio suggest decreasing aquifer temperatures in the vicinity of this well. 
TABLE 5. COMPARISON OF 1974 AND 1989 CHEMICAL ANALYSES OF GEOTHERMAL WATERS.

\begin{tabular}{|c|c|c|c|c|c|c|c|c|c|c|c|c|c|c|c|c|c|}
\hline $\begin{array}{l}\text { Address } \\
\text { Location }^{2}\end{array}$ & Date & $\begin{array}{c}\text { Temp } \\
{ }^{\circ} \mathrm{C}\end{array}$ & $\mathrm{pH}$ & $\begin{array}{c}\mathrm{EC} \\
\mu \mathrm{mhos} / \mathrm{cm}\end{array}$ & $\begin{array}{l}\mathrm{SiO}_{2} \\
\mathrm{mg} / \mathrm{l}\end{array}$ & $\begin{array}{c}\mathrm{Na} \\
\mathrm{mg} / \mathrm{l}\end{array}$ & $\underset{\mathrm{mg} / \mathrm{K}}{\mathrm{K}}$ & $\begin{array}{c}\mathrm{Li} \\
\mathrm{mg} / \mathrm{l}\end{array}$ & $\begin{array}{c}\mathrm{Ca} \\
\mathrm{mg} / \mathrm{l}\end{array}$ & $\begin{array}{c}\mathrm{Mg} \\
\mathrm{mg} / \mathrm{l}\end{array}$ & $\begin{array}{c}\mathrm{B} \\
\mathrm{mg} / \mathrm{l}\end{array}$ & $\begin{array}{l}\mathrm{SO}_{4} \\
\mathrm{mg} / \mathrm{l}\end{array}$ & $\underset{\mathrm{mg} / \mathrm{l}}{\mathrm{Cl}}$ & $\begin{array}{c}\mathrm{HCO}_{3} \\
\mathrm{mg} / \mathrm{l}\end{array}$ & $\begin{array}{l}\mathrm{CO}_{3} \\
\mathrm{mg} / \mathrm{l}\end{array}$ & $\begin{array}{c}\mathrm{F} \\
\mathrm{mg} / 1\end{array}$ & $\begin{array}{c}\text { As } \\
\mathrm{mg} / \mathrm{l}\end{array}$ \\
\hline Well A & $4-23-74$ & 59.0 & 7.76 & 886 & 85.8 & 154.7 & 6.55 & 0.18 & 5.68 & 0.40 & 0.6 & 226.7 & 26 & 143.6 & - & 0.5 & 0.01 \\
\hline T19N R19E 24BCD & $9-27-89$ & 54.0 & 8.28 & 971 & 93.7 & 189 & 9.42 & 0.14 & 20.3 & 0.98 & 1.2 & 281 & 30.1 & 180 & - & 3.01 & 0.09 \\
\hline Well B & $3-1-74$ & 63.1 & 8.05 & 1035 & 92.6 & 189.35 & 5.5 & 0.14 & 16.5 & 0.405 & 1.36 & 304.6 & 33.5 & 131.5 & - & 4.18 & 0.11 \\
\hline T19N R19E 25CBB & $8-10-89$ & 53.0 & 8.26 & 1110 & 99 & 211 & 6.10 & 0.19 & 21.5 & 0.60 & 1.5 & 350 & 36.3 & 120 & - & 3.94 & 0.13 \\
\hline Well C & $2-18-74$ & 80.0 & 7.5 & 1070 & 103.7 & 248 & 7.1 & 0.22 & 20.5 & 0.32 & 1.74 & 419 & 53 & 95 & - & 4.95 & 0.09 \\
\hline T19N R19E 26DABA & $12-02-89$ & 37.0 & 7.94 & 1160 & 86.7 & 217 & 6.21 & 0.207 & 24.7 & 0.74 & 1.70 & 392 & 41.3 & 108 & - & 4.3 & 0.07 \\
\hline Well D & $3-01-74$ & 85.0 & 7.78 & 1430 & 92.3 & 258.7 & 7.17 & 0.18 & 22.1 & 0.79 & 2.08 & 478.2 & 53 & 99 & - & 4.8 & 0.11 \\
\hline T19N R19E 26ADA & $12-14-89$ & - & 8.13 & 1360 & 116 & 257 & 8.62 & 0.24 & 27.8 & 0.15 & 2.4 & 486 & 48.4 & 94.6 & - & 5.1 & 0.14 \\
\hline Well E & $5-3-74$ & 85.0 & 8.35 & 1423 & 111 & 243.2 & 7.71 & 0.19 & 14.23 & 0.19 & 1.87 & 448.8 & 54 & 97.55 & - & 5.1 & 0.006 \\
\hline T19N R19E 26ADAB & $10-01-89$ & 70.0 & 8.05 & 1350 & 118 & 265 & 8.42 & 0.24 & 27.4 & 0.17 & 2.2 & 479 & 49.2 & 86.9 & - & 4.83 & 0.11 \\
\hline Well F & $12-08-73$ & 78.0 & 8.20 & 1320 & 103.2 & 293 & 8.1 & - & 25 & 0.26 & 1.77 & 465.5 & 53 & 100.6 & - & 6.3 & 0.20 \\
\hline T19N R19E 26ADDA & $12-08-89$ & 49.0 & 8.19 & 1390 & 113 & 272 & 8.30 & 0.244 & 28.3 & 0.20 & 2.5 & 490 & 50.0 & 97.0 & - & 5.1 & 0.15 \\
\hline Well G & $3-01-74$ & 90.0 & 7.65 & 1185 & 134.7 & 203 & 7.37 & 0.16 & 28.98 & 0.786 & 1.80 & 348.3 & 42.0 & 146.0 & - & 4.8 & 0.04 \\
\hline T19N R19E 26ADCC & $9-28-89$ & 55.0 & 8.05 & 1330 & 99.1 & 260 & 7.64 & 0.25 & 27.8 & 0.26 & 2.1 & 475 & 48.5 & 82.7 & - & 4.90 & 0.11 \\
\hline Well $\mathbf{H}$ & $3-01-74$ & 42.0 & 7.95 & 942 & 57.8 & 175 & 5.96 & 0.12 & 15.8 & 1.49 & 0.75 & 258.3 & 31 & 131.0 & - & 0.75 & 0.13 \\
\hline T19N R19E 24BBA & $9-28-89$ & 42.0 & 8.39 & 854 & 60.8 & 164 & 5.20 & 0.12 & 15.9 & 1.08 & 0.9 & 249 & 25.8 & 134 & 2.2 & 1.25 & 0.13 \\
\hline Well I & $2-05-74$ & 47.2 & 8.06 & 724 & 85.4 & 139 & 7.38 & 0.17 & 5.20 & 0.30 & 0.76 & 170.6 & 20.2 & 135.9 & - & 0.81 & 0.10 \\
\hline T19N R19E 24CABA & $10-19-89$ & 52.0 & 8.30 & 965 & 91.7 & 181 & 8.85 & 0.145 & 19.3 & 0.38 & 1.4 & 295 & 29.9 & 133 & - & 2.1 & 0.14 \\
\hline Well $\mathbf{J}$ & $4-30-74$ & 89.9 & 8.29 & 1367 & 102 & 243.19 & 7.36 & 0.19 & 23.4 & 0.205 & 1.99 & 457 & 50 & 86.2 & - & 4.83 & 0.10 \\
\hline T19N R19E 26ADDD & $11-29-89$ & 76.0 & 8.09 & 1330 & 112 & 254 & 8.54 & 0.247 & 27.8 & 0.17 & 2.2 & 474 & 48.2 & 85.9 & - & 5.0 & 0.13 \\
\hline
\end{tabular}

Temp ${ }^{1}$ - temperatures obtained from well logs or literature.

Location ${ }^{2}$ - based on Township, Range, and Section.

- (data not available) 


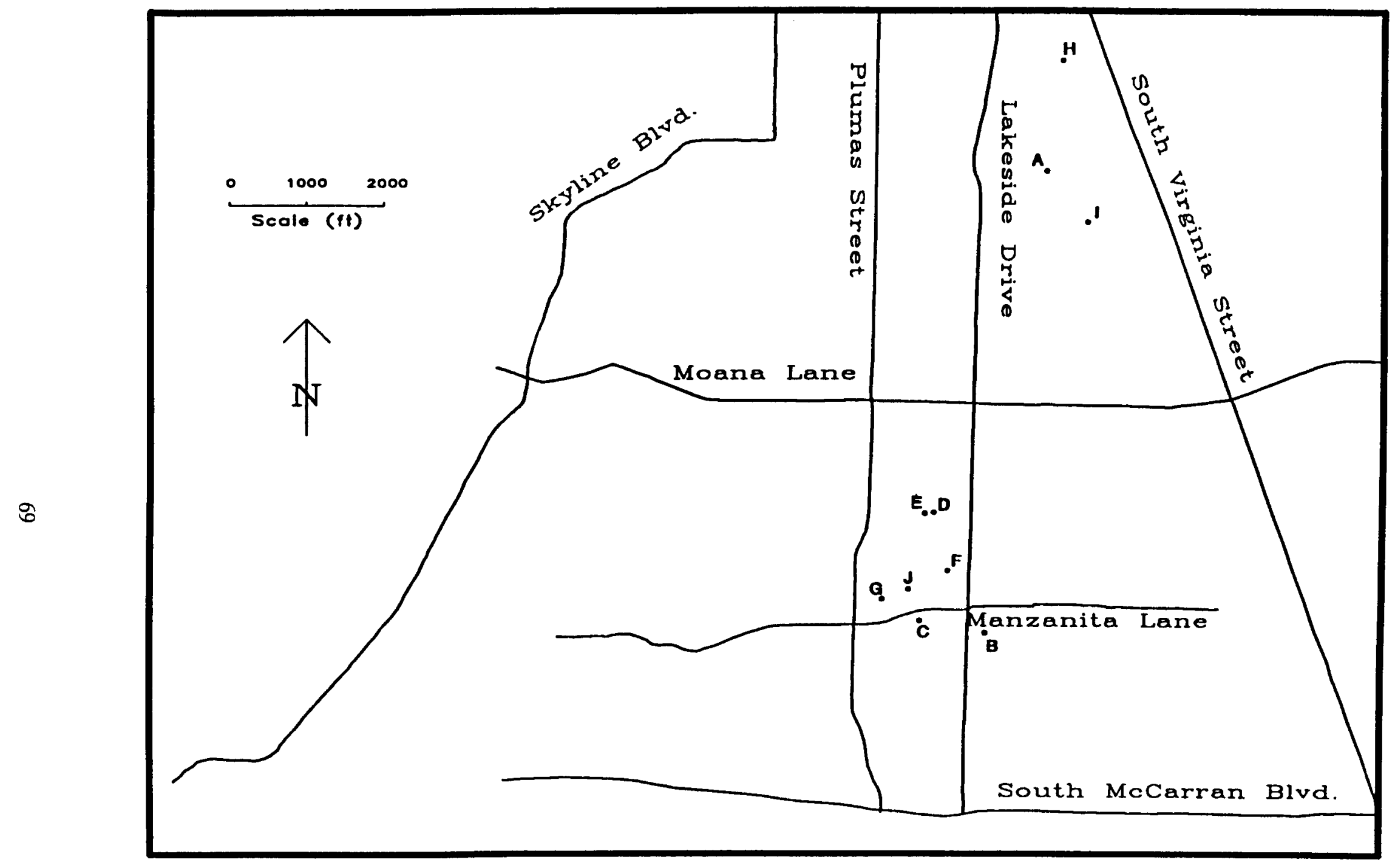

FIGURE 45. Location of 10 Geothermal Wells in the Moana Geothermal Area from which Chemical Data were Collected. 


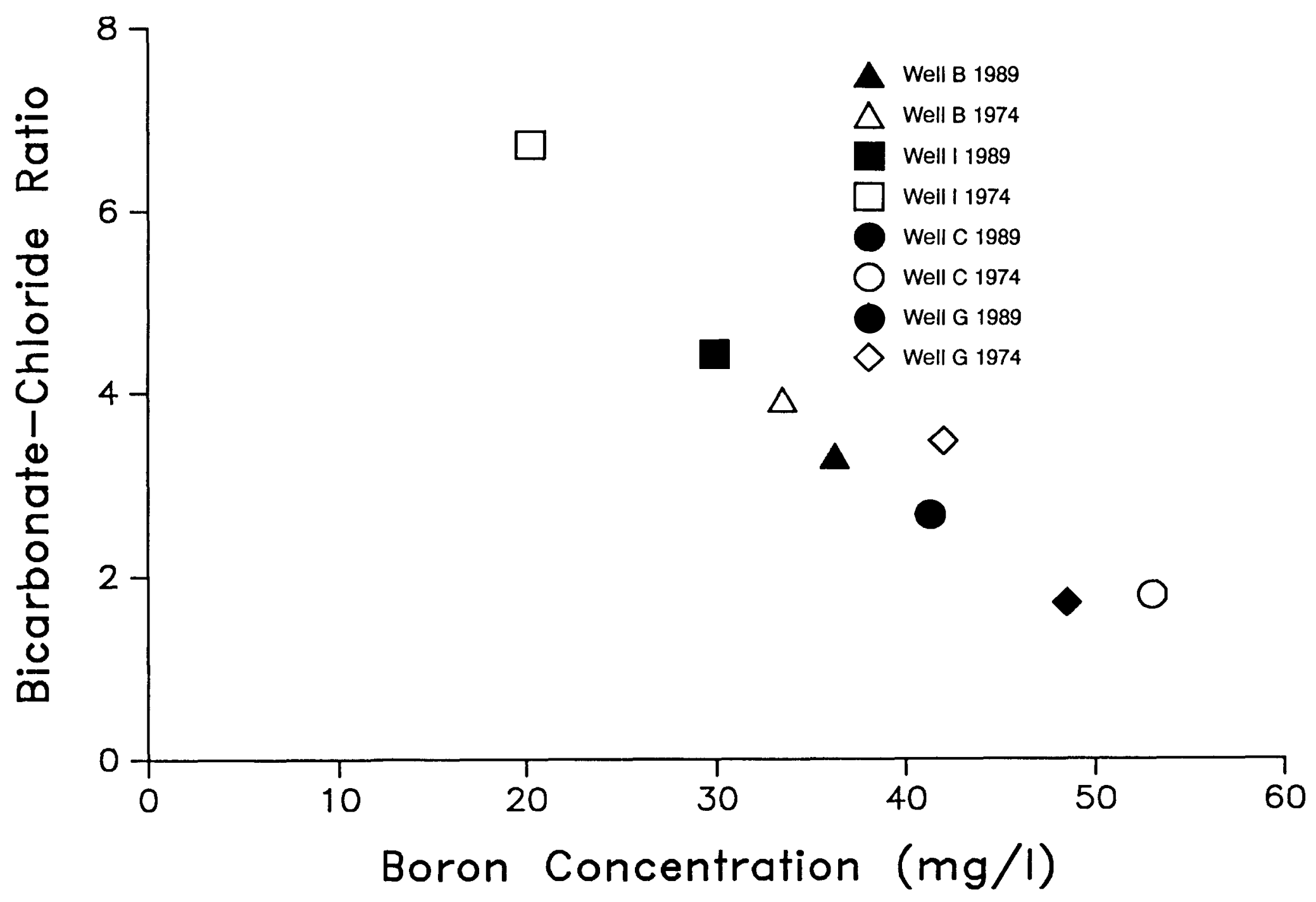

FIGURE 46. Temporal Variations in Bicarbonate-Chloride Ratio versus Chloride Concentration for Well B, Well I, Well C, and Well G. 


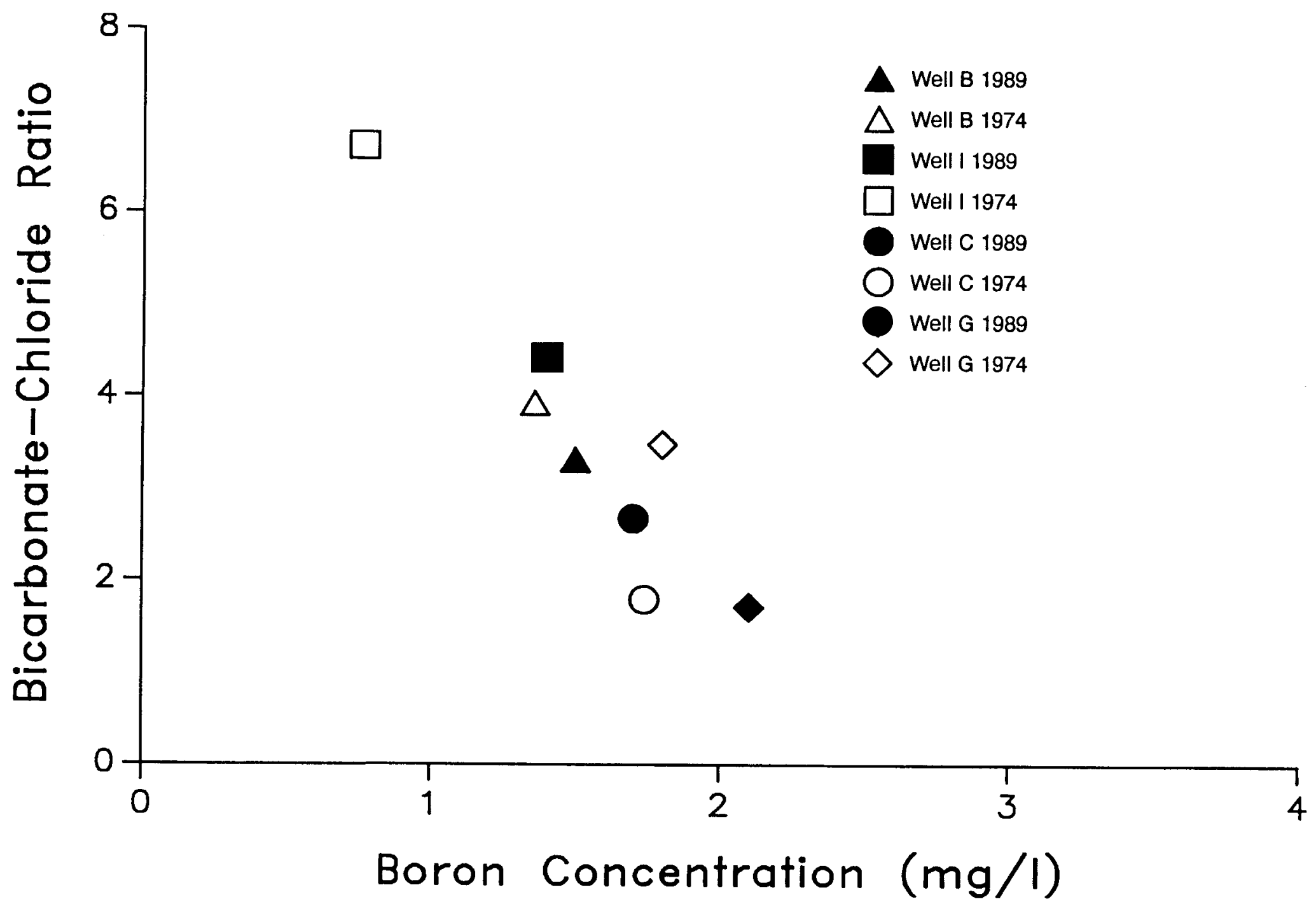

FIGURE 47. Temporal Variations in Bicarbonate-Chloride Ratio versus Boron Concentration for Well B, Well I, Well $\mathrm{C}$, and Well G. 


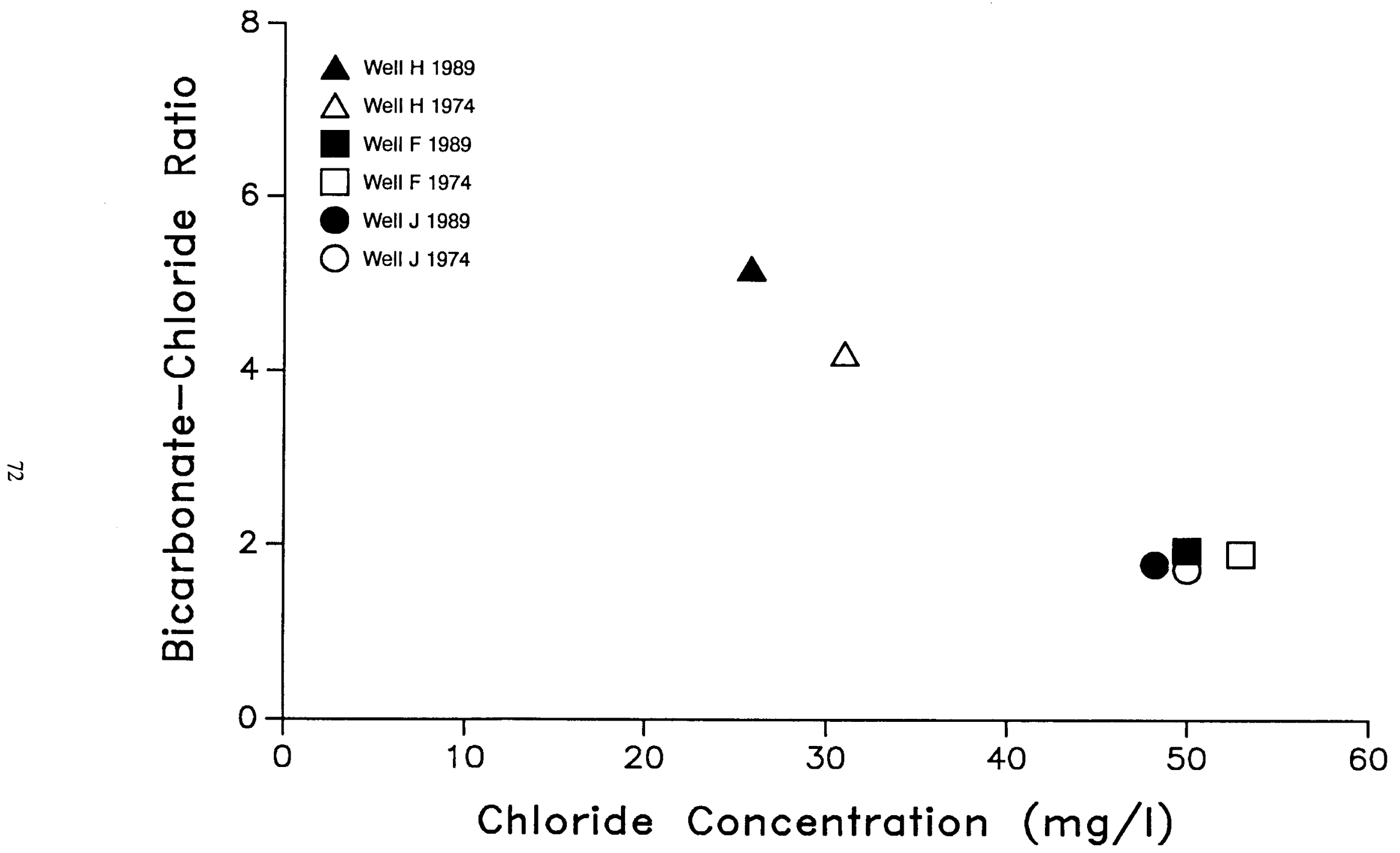

FIGURE 48. Temporal Variations in Bicarbonate-Chloride Ratio versus Chloride Concentration for Well $\mathrm{H}$, Well $\mathrm{F}$, and Well $\mathrm{J}$. 


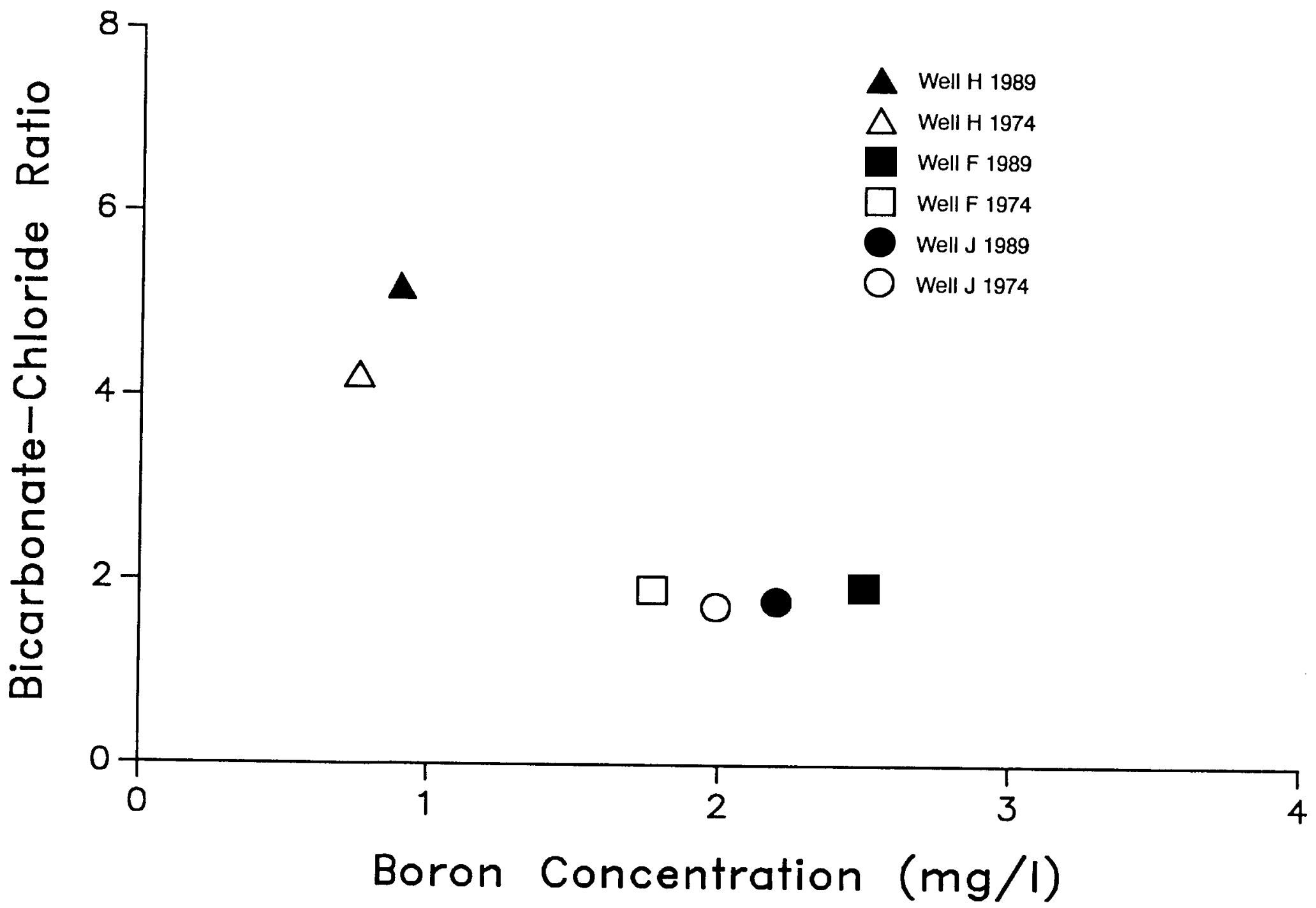

FIGURE 49. Temporal Variations in Bicarbonate-Chloride Ratio versus Boron Concentration for Well H, Well F, and Well J. 
Figures 50 and 51 present the bicarbonate-chloride ratio versus chloride concentration and boron concentration relationships, respectively, for Well A, Well D and Well E. The water chemistry of these wells has either remained constant or the changes observed are inconclusive with respect to temperature variation.

Five of the 10 wells resampled showed significant water chemistry variations. Three wells, Well B, Well I and Well $\mathrm{G}$ had an increase in thermal water constituents, suggesting an increase in water temperatures at these locations. Two locations, Well C and $\mathrm{Well} \mathrm{H}$, had a decrease in thermal water constituents which suggests declining temperatures in the wells.

Unfortunately, no clear pattern of water chemistry variation is apparent based on the location of the wells. The two wells which exhibited a decline in thermal water constituents are in different parts of the geothermal area. Well $\mathrm{C}$ is in the central portion of the resource area (the area which has experienced the greatest decline in aquifer pressures) and Well $\mathrm{H}$ is on the northeast boundary of the resource area, see Figure 45. The other water chemistry data do not confirm that aquifer conditions are changing in the vicinity of these well locations. Two wells approximately $500 \mathrm{ft}$ from Well C either exhibited no change in water chemistry (Well $\mathrm{J}$ ) or showed an increase in thermal water constituents (Well G). Similar inconclusive behavior was observed in the vicinity of Well H. The closest sampling location to this well is approximately $1,500 \mathrm{ft}$ away at Well A. Well A exhibited ambiguous changes in water chemistry which do not confirm decreasing aquifer temperatures on the northeast boundary of the geothermal area.

The three wells which exhibited an increase in thermal water constituents are also in different locations. Well $\mathrm{G}$ is in the central part, Well $\mathrm{B}$ is in the eastern part, and Well I is the northeastern part of the resource area, respectively, see Figure 45. The mechanism for the increase in thermal water constituents in these wells is not clearly understood. The data suggest that the quantity of nonthermal water mixing in the geothermal aquifer has declined at these locations. A possible reason for the decrease in nonthermal water quantity is a reduction in recharge rate to the nonthermal water aquifers of the area. Changes in land use and four years of drought may account for a reduction in recharge rate to the nonthermal water aquifers.

Although the data are limited, they suggest that aquifer conditions are changing in parts of the resource area. Additional sampling is needed before conclusions can be made about long-term chemical and thermal changes taking place in the Moana geothermal area.

\section{CHEMICAL GEOTHERMOMETERS}

The chemical data obtained from the 10 geothermal wells shown in Figure 45 were used to estimate the reservoir temperature for the Moana geothermal system. Measured temperatures and estimates obtained from chemical geothermometers 


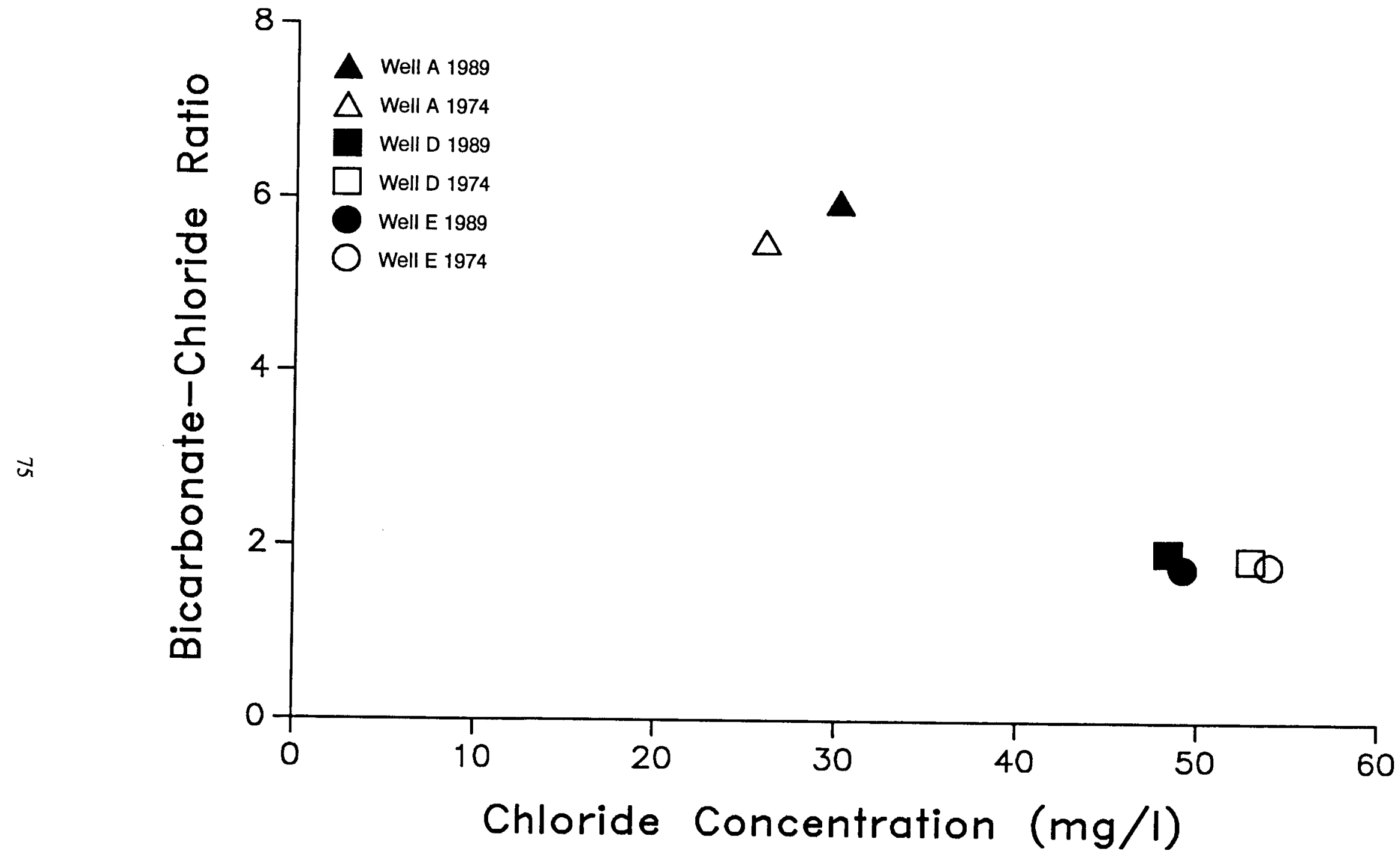

FIGURE 50. Temporal Variations in Bicarbonate-Chloride Ratio versus Chloride Concentration for Well A, Well $D$, and Well E. 


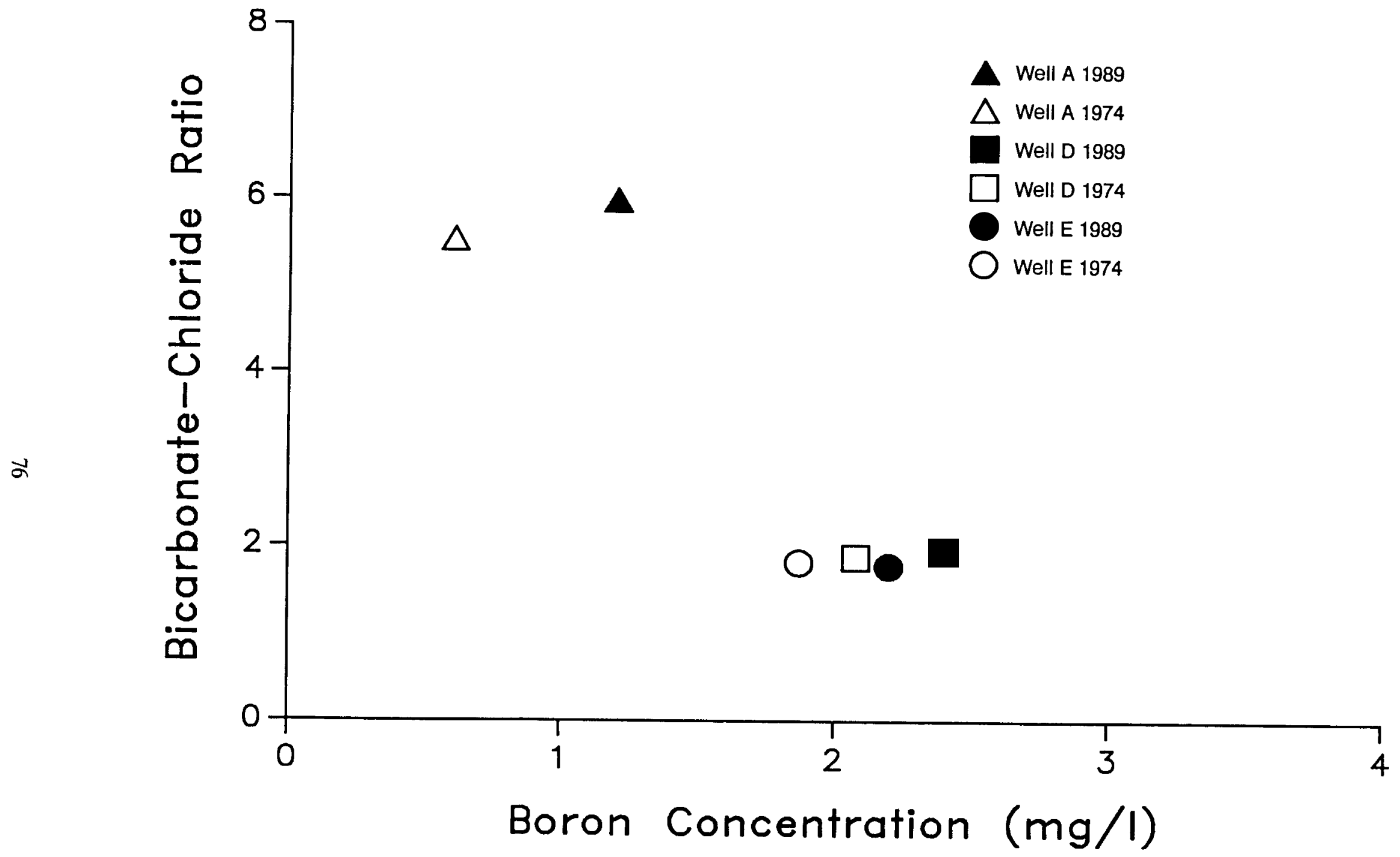

FIGURE 51. Temporal Variations in Bicarbonate-Chloride Ratio versus Boron Concentration for Well A, Well D, and Well $E$. 
based on $\mathrm{SiO}_{2}$ and $\mathrm{Na}-\mathrm{K}-\mathrm{Ca}$ are presented in Table 6. For all wells, the measured temperatures were lower than the estimates obtained from chemical geothermometers. This result is expected because of the mixing of thermal and nonthermal waters which influences the measured temperatures at well locations. Temperatures estimated by chemical geothermometers are most representative of reservoir temperatures at depth.

The reservoir temperatures estimated from the chemical geothermometer based on silica were in the range of 111 to $147^{\circ} \mathrm{C}$, which is in good agreement with the range obtained by Flynn and Ghusn (1984) of 120 to $150^{\circ} \mathrm{C}$. The values estimated from the chemical geothermometer based on $\mathrm{Na}-\mathrm{K}-\mathrm{Ca}$ indicated a broader range (87 to $147^{\circ} \mathrm{C}$ ) and generally reproduces the results of Flynn and Ghusn (1984) of 85 to $150^{\circ} \mathrm{C}$. 
TABLE 6. COMPARISON OF MEASURED TEMPERATURES TO ESTIMATES OBTAINED FROM CHEMICAL GEOTHERMOMETERS.

\begin{tabular}{cccc} 
& $\begin{array}{c}\text { Measured } \\
\text { Temperature }\left({ }^{\circ} \mathrm{C}\right)\end{array}$ & \multicolumn{2}{c}{ Chemical Geothermometers $\left({ }^{\circ} \mathrm{C}\right)$} \\
\cline { 3 - 4 } Well A & 54 & 133.6 & $\mathrm{Na}-\mathrm{K}-\mathrm{Ca}_{2}{ }^{(\mathrm{b})}$ \\
Well B & 53 & 136.6 & 147.1 \\
Well C & 37 & 129.4 & 89.2 \\
Well D & - & 145.7 & 86.9 \\
Well E & 70 & 146.7 & 97.7 \\
Well F & 49 & 144.1 & 97.6 \\
Well G & 55 & 136.7 & 96.6 \\
Well H & 42 & 111.2 & 93.5 \\
Well I & 52 & 132.4 & 87.7 \\
Well J & 76 & 143.6 & 146.0 \\
\hline
\end{tabular}
(a) Fournier, 1977
(b) Fournier and Truesdell, 1973
- (data not available) 


\section{NUMERICAL MODELING OF MOANA GEOTHERMAL SYSTEM}

The development of a conceptual model based on all available information is the first step in constructing a numerical model of any groundwater flow system. The conceptual model, together with measured or estimated hydraulic properties, boundary conditions and initial conditions (if transient conditions apply) and a numerical code, such as SUTRA developed by the USGS, are the necessary components for simulation of the geothermal system.

\section{CONCEPTUAL MODEL}

The general conceptual model proposed by Bateman and Scheibach (1975) (which is a lateral leakage model, as shown in Figure 3) continues to be supported by the new data obtained during this study. The thermal water rises along normal faults in the western and central portions of the Moana geothermal area (see Figure 2) and then moves laterally in the permeable horizons away from the faults. The geothermal aquifer is a leaky confined aquifer with an unconfined aquifer with nonthermal water overlaying it. Thus, in the conceptual model, heat is added from below the geothermal aquifer at the fault locations due to rising hot water and heat is removed from above by the conductive heat flux caused by the temperature difference between the geothermal aquifer and the unconfined aquifer above it. Because there is a spatial variation in temperature in the geothermal aquifer, there is expected to be a spatial variation in the conductive heat flux to the unconfined aquifer.

In the conceptual model, the thermal water is proposed to rise along the normal faults, which leads to a flux of water into the geothermal aquifer from below at the fault locations. As demonstrated by the analysis of the hydrochemical data for this study and the isotopic work by Flynn and Ghusn (1984), there is mixing of nonthermal and thermal waters, which implies downward leakage from the unconfined aquifer to the geothermal aquifer. Based on observations during drilling of geothermal wells (Scheibach, 1975), the hydraulic head in the geothermal aquifer near the faults has been found to be higher than the hydraulic head in the unconfined aquifer. Thus, near the faults, possible upward leakage may be taking place. In summary, there is a flux of water into the geothermal aquifer from below at the faults, a possible flux out of the geothermal aquifer to the unconfined aquifer near the faults, and a flux into the geothermal aquifer from the overlying unconfined aquifer. In addition, the local flow of groundwater in the geothermal aquifer (as indicated by the hydraulic head pattern shown previously in Figure 31) is from the southwest to the northeast and east and is assumed to represent the horizontal fluxes. A schematic indicating the various fluxes in the conceptual model is given in Figure 52 .

The geology of the geothermal aquifer is very complex and suggests a large degree of heterogeneity in the aquifer properties (see Figure 2). There was insufficient infor- 


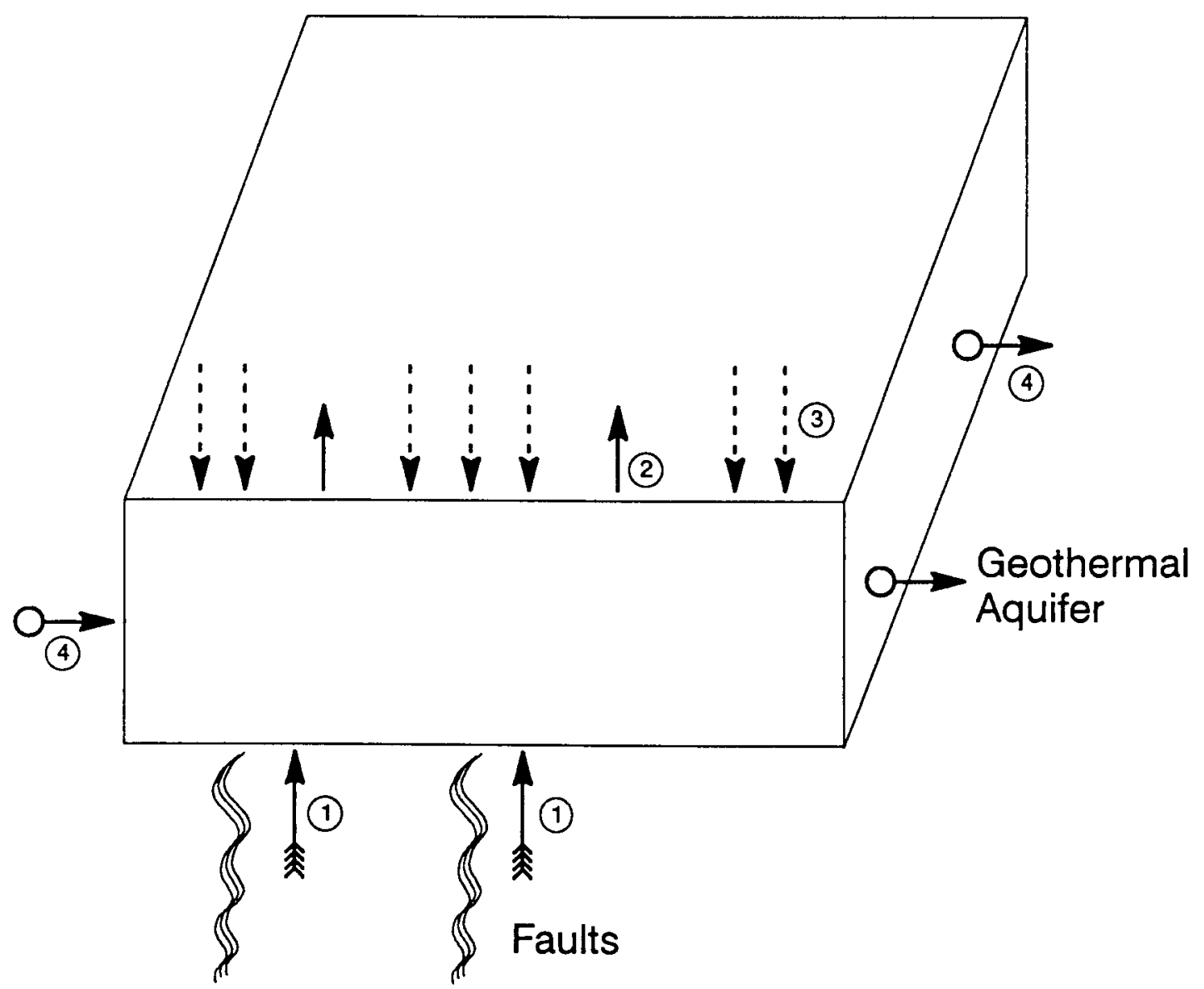

1. Flux of hot water into geothermal aquifer $\uparrow$

2. Upward leakage due to head gradient between aquifers

3. Downward leakage due to head gradient between aquifers

4. Horizontal fluxes due to local groundwater gradients

FIGURE 52. Schematic of Fluxes of Water in the Conceptual Model of the Moana Geothermal System. 
mation to develop a detailed conceptual model of the geology of the geothermal aquifer. Therefore, the initial assumption used here was that the intrinsic permeability of the aquifer was homogeneous and the aquifer was of variable thickness. Allowing the thickness of the aquifer to vary introduced some heterogeneity in transmissivity over the area.

\section{NUMERICAL MODEL AND INPUT DATA}

The USGS code SUTRA was selected for use in this project because it considers both groundwater flow and heat transport. In addition, the goal of developing a numerical model of the Moana geothermal system that could be used by regulators required a numerical code that was documented and readily available, such as SUTRA. A detailed documentation of the governing groundwater flow and thermal transport equations solved by SUTRA are found in Voss (1984). A listing of the code and the corresponding user's manual can also be found in the report by Voss. SUTRA is a finite element model for simulation of two-dimensional problems that are either steady state or transient. Although the model is two-dimensional, variable thicknesses are allowed as input parameters.

In applying SUTRA to the Moana geothermal aquifer, the decision was made to concentrate on modeling the system as steady state. The water level data collected during this project are found in Appendix III. In general, the water level variation with time at the sampled wells was not large. This observation lead to the decision to model the Moana geothermal system as steady state. The data from September 1989 was chosen with the expectation that the system had recovered from the previous year's heating load. The spatial distribution of temperature shown in Figure 53 was based on the 26 temperature values measured for September 1989 and knowledge of historical data. As observed in the figure, there are two regions of higher temperature which generally correspond to the locations of the faults. To develop a calibrated model of the Moana geothermal system, this temperature distribution must be reproduced.

In fluid-density-dependent groundwater flow, as formulated in SUTRA, the governing equations are written in terms of pressure and not hydraulic head. The spatial distribution of hydraulic head was shown previously in Figure 31. A reference elevation of $4,200 \mathrm{ft}$ was assumed to represent a reasonable average elevation of the geothermal aquifer and the spatial distribution of pressure was calculated based on the hydraulic heads shown in Figure 31. The same flow patterns and gradients observed in the hydraulic head distribution are, of course, found in the pressure distribution.

The thickness of the Moana geothermal aquifer was obtained from the drillers' geologic logs of the geothermal wells and varied from $75 \mathrm{ft}$ to over $200 \mathrm{ft}$. A spatial distribution of thickness was developed by contouring the information from the well logs. The thickness pattern was very qualitative due to the nature of the drillers' well logs. 


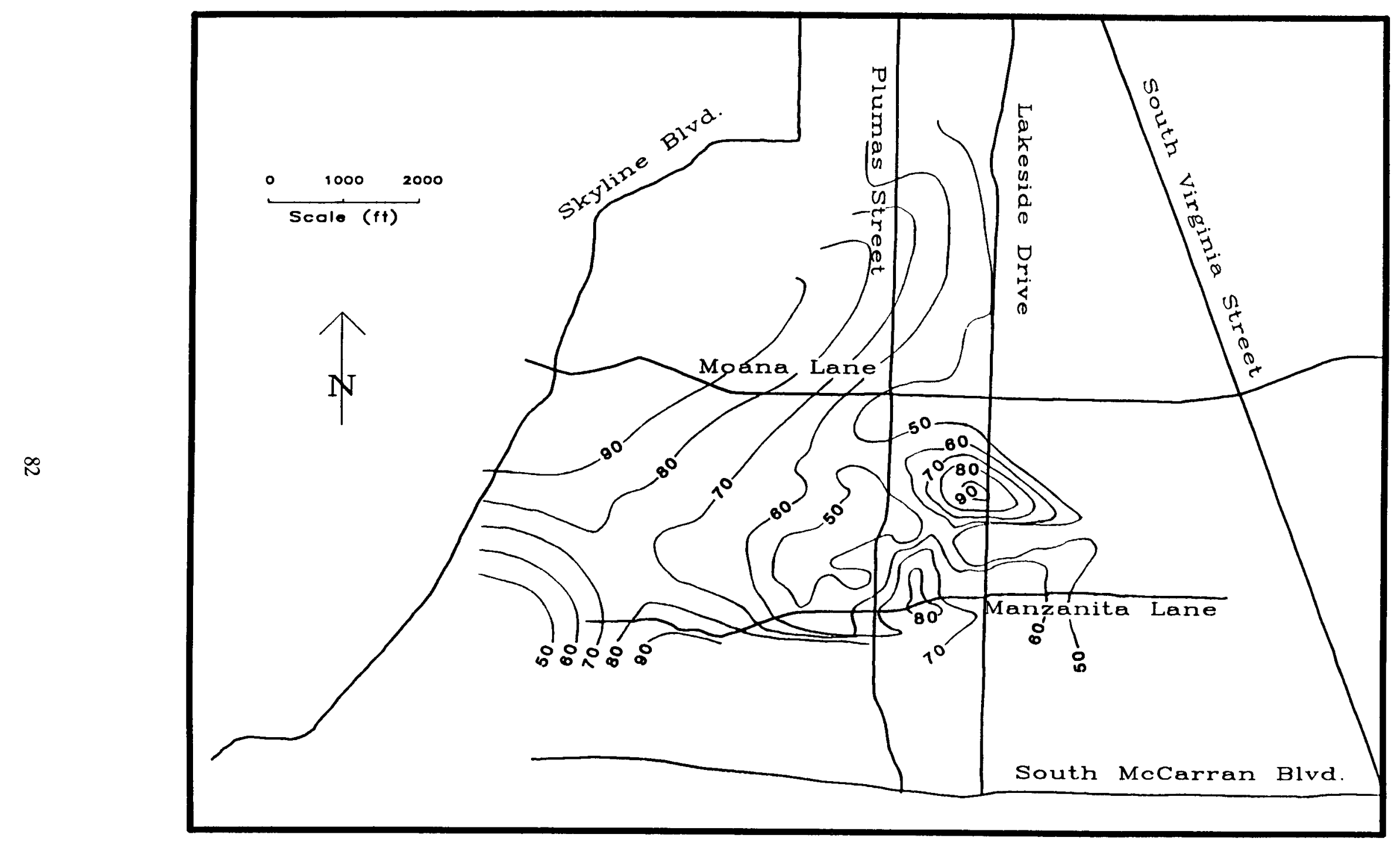

FIGURE 53. Spatial Distribution of Temperature $\left({ }^{\circ} \mathrm{C}\right)$ for September 1989 for the Moana Geothermal Area. 
As discussed previously in the chapter on the description of the study area, there exists only limited information on the hydrologic properties of the Moana geothermal aquifer. Therefore, an intrinsic permeability of $1.42 \times 10^{-12} \mathrm{~m}^{2}$ was assumed for the aquifer. This permeability is based on an average of the available data. A porosity value of 0.35 was assumed for the geothermal aquifer for this study.

For the steady-state modeling, prescribed pressure and temperature boundary conditions were assumed. Prescribed fluid flux and thermal flux boundary conditions could not be used due to lack of flux information. The prescribed pressure and temperature values were based on the contoured pressure and temperature distributions and are uncertain because of the limited measured data near the boundaries (see Figure 8). The grid for the steady-state modeling is composed of 296 nodes and 250 elements and is shown in Figure 54. The additional detail in the center of the grid represents the area of high density of wells (see Figure 8).

The basic input file (Unit 5) for SUTRA is given in Appendix IV, together with the file of initial conditions (Unit 55). All dimensions are either in or scaled to kilogram, meter, and second units.

\section{RESULTS OF PRELIMINARY STEADY-STATE MODELING}

The goal of the steady-state modeling was to reproduce the pressure distribution based on the measured hydraulic heads (see Figure 31) and the temperature distribution (see Figure 53) obtained from the nonheating period in September 1989. As discussed in the section concerning the conceptual model, thermal water rises along the faults in the western and central portion of the study area. This is consistent with the distribution of temperature presented in Figure 53. Thus, heat and fluid are added to the thermal aquifer from below. No information concerning the amount of heat or quantity of water rising along the faults is available.

Conductive heat loss from the thermal aquifer to the unconfined aquifer above is expected due to the temperature differences. The spatial distribution of conductive heat loss could be estimated using Fourier's law if the thermal conductivity and thickness of the layer between the two aquifers are known, and the spatial distribution of temperatures in both aquifers is available (Mercer and Faust, 1979). Unfortunately, no spatial distribution of temperature was measured in the unconfined aquifer and geologic information concerning the layer between the aquifers is limited.

An additional unknown is the spatial distribution of leakage between the thermal and unconfined aquifers. The hydrochemical data indicated mixing of waters, but could not be used to quantify the amount and direction of leakage. Darcy's law could be used to estimate the leakage if the hydraulic conductivity and thickness of the layer between the two aquifers and the spatial distribution of hydraulic head for both aquifers are 


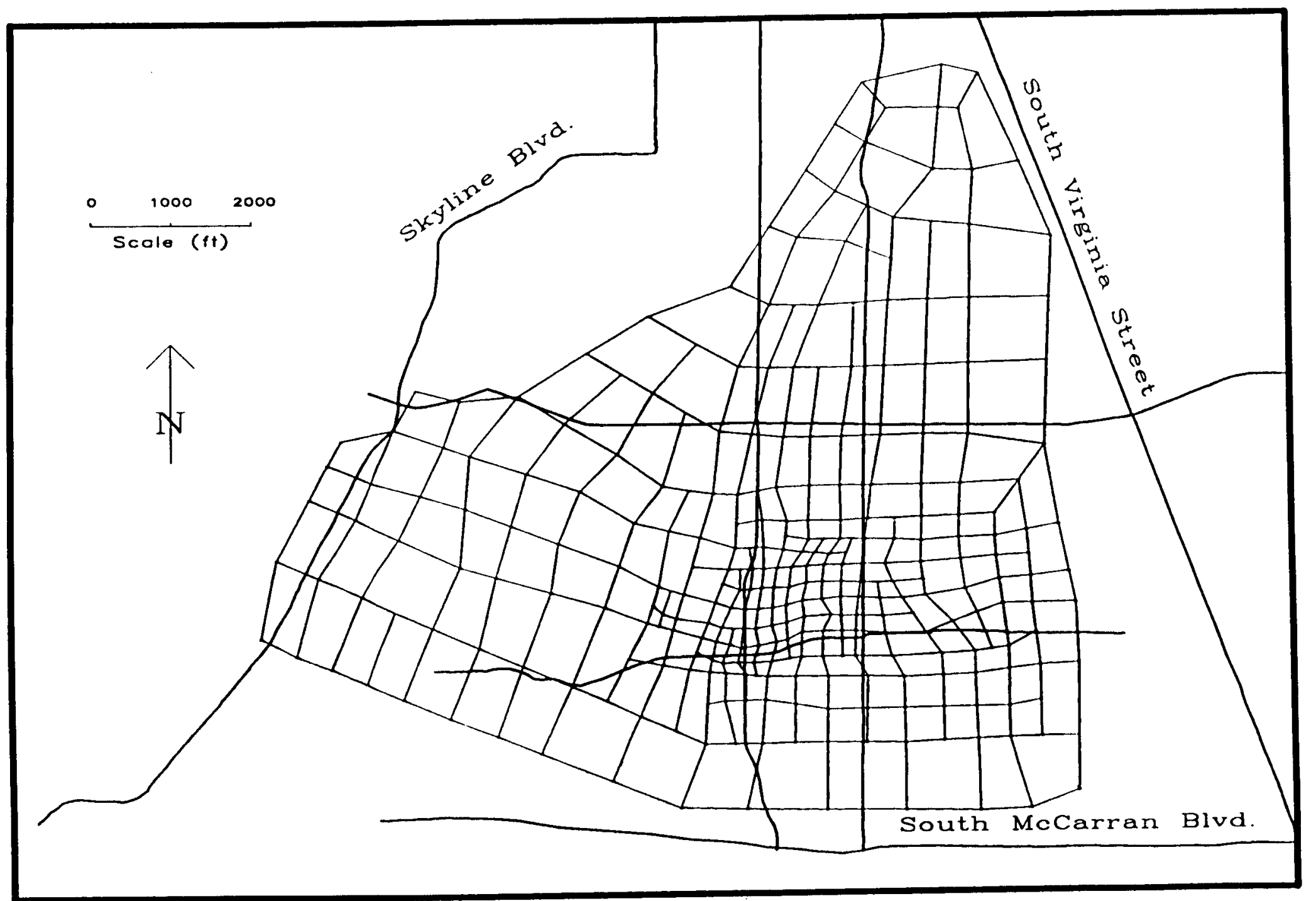

FIGURE 54. Finite Element Grid for Modeling of the Moana Geothermal Area. 
known. No measurements of hydraulic head in the unconfined aquifer were made in this study and there is limited information on the thickness of the layer between the aquifers.

The lack of information concerning thermal and fluid fluxes from above and below the Moana geothermal aquifer lead to a highly unconstrained problem. In the preliminary modeling efforts, we could begin to establish temperature gradients by adding heat to nodes near the faults and removing heat at neighboring nodes. However, the amount of heat added and removed was, to some degree, arbitrary and could not be verified with measured or reliably estimated information. At this point, it became clear that there were too many unknowns for continued modeling of the Moana geothermal aquifer and that considerable additional thermal and hydraulic data would be needed to obtain a representative model of this system in either two or three dimensions.

\section{DISCUSSION}

The process of developing a numerical model for the Moana geothermal system led to several conclusions. The thermal and fluid fluxes into and out of the Moana geothermal system have both horizontal and vertical components. The true physical model of the geothermal system therefore requires a three-dimensional description. However, the geothermal system may be modeled in two dimensions if the vertical thermal and fluid fluxes are known and considered as prescribed values at each node point. These fluxes cannot be estimated at this time due to lack of data. To estimate the thermal and fluid fluxes between the geothermal aquifer and the overlying unconfined aquifer, the following additional data are needed:

1. spatial distribution of thickness of layer between the geothermal and unconfined aquifers;

2. hydraulic conductivity of layer between the two aquifers;

3. thermal conductivity of layer between the two aquifers;

4. spatial distribution of hydraulic heads in the overlying unconfined aquifer; and

5. spatial distribution of temperatures in the overlying unconfined aquifer.

The thermal and fluid fluxes rising up the faults are unknown but could be considered as part of the calibration parameters if the information listed above were available.

Modeling the Moana geothermal system as steady sate was considered to be reasonable based on the small changes in the water levels and temperatures for most of the wells. An attempt to calibrate the Moana geothermal system by transient modeling would require transient information on hydraulic heads, temperatures, thermal fluxes, and fluid fluxes far in excess of what is currently available. 
The development of a calibrated numerical model for the Moana geothermal system is not possible at this time. However, if the additional data listed above could be collected, constructing a realistic numerical model to simulate the Moana geothermal system that then could be used to investigate various development scenarios may be possible.

Several resource development scenarios were identified during this study. The continued pumping of geothermal water by many homeowners has lead to a decrease in hydraulic head in the central portion of the study area. The impact of the continued pumping as well as additional pumping at new geothermal wells should be investigated. Based on the available data, both the chemistry and temperature of the geothermal water do not appear to have substantially changed with time. If, at some time, injection of water is required to offset the decreasing hydraulic heads, simulations should be conducted to investigate the effect on the geothermal system of injection of lower temperature water. 


\section{CONCLUSIONS AND RECOMMENDATIONS}

This research grant was received from the DOE, Idaho Operations Office, to evaluate and simulate the Moana geothermal system. Toward this goal, all available hydraulic, thermal, well, geologic, hydrochemical, and hydrologic historical data were collected and evaluated. The historical data were fragmented in time such that it was not possible to construct spatially distributed hydraulic head or temperature maps with time. Although there are over 188 geothermal wells in the study area, data from many well logs are incomplete or very qualitative. With so many gaps in the historical database, the data collection phase of the project was planned to be as complete and consistent as possible for the 13-month period.

Water levels and temperature with depth were collected for a 13-month period at 26 geothermal wells. Analysis of these data suggests that in the central portion of the study area where there is a high density of wells with pumps, the water levels have declined with time. The monitoring well at Horseman's Park upgradient of the main resource area shows a water level increase of $5 \mathrm{ft}$ between 1984 and 1989. The monitoring well at Manzanita Park that is generally downgradient of the main resource area shows a decrease in water level since 1984. Based on this information, pumping of wells in the Moana geothermal area is impacting the hydraulic heads (or aquifer pressures) near these wells.

The analysis of the temperature with depth data collected during this study indicated that well construction has an impact on the temperature measurement. The maximum temperature measured at the geothermal wells was influenced by the downhole hardware, such as heat exchangers. Thus, the maximum temperature measured is likely to be less than the value in the reservoir. For the two monitoring wells at Horseman's Park and Manzanita Park, the temperature with depth data measured for this study was relatively constant with heating and nonheating season and are very similar to the data obtained by Flynn and Ghusn (1984).

The groundwater chemistry indicates a mixing of thermal and nonthermal waters which agrees with the isotopic results of Flynn and Ghusn (1984). The concentration with temperature relationships for various soluble elements, such as boron and chloride, could be used to indicate, in a relative sense, temperature changes in the geothermal reservoir at a given well location. Obtaining representative measurements of reservoir temperature changes from geothermal wells used for heating is not possible due to the downhole hardware and heat load demands. However, a technique based on the use of temporal changes in chemical data at geothermal wells to indicate temperature changes at those locations has been investigated and shows great promise. The analysis of groundwater chemistry with time at 10 geothermal wells gave no clear indication of spatial patterns of temperature change. 
The information obtained from both the historical data and the 13-month data collection phase of this project indicates that there are horizontal and vertical thermal and fluid fluxes in the Moana geothermal system. The attempt to develop a calibrated two-dimensional, steady-state numerical model of the Moana geothermal aquifer was hampered by a lack of information concerning the thermal and fluid fluxes which lead to an unconstrained problem. The observed temperature gradients could be locally reproduced by adding heat at the faults and removing heat at nearby nodes in a trial and error process. However, the quantity of heat added and removed could not be justified or compared to any measurements of thermal or fluid fluxes. Therefore, the development of a calibrated numerical model of the Moana geothermal aquifer is not possible at this time with the available data. Detailed information about the horizontal and vertical thermal and fluid fluxes is necessary before a calibrated numerical model can be developed. In addition, more geologic and hydrologic information for the Moana geothermal aquifer needs to be obtained before a predictive numerical model could be used to investigate resource development scenarios. The primary resource development scenario identified during this research is the continued and possible expansion of pumping at the geothermal wells. The current pumpage has produced decreases in hydraulic head in the center of the study area. These hydraulic head changes may, in time, have an adverse impact on the geothermal system by inducing additional leakage of cooler water from the nonthermal aquifer. To predict the impact, a calibrated model of the Moana geothermal system, together with the location and rates of pumping, will be needed. Currently, no information about rates of pumping are available for geothermal wells used for home heating purposes.

Several recommendations can be made based on the analysis of the water level, temperature, and groundwater chemistry data from this project. Further monitoring of the Moana geothermal system should involve measurements on an annual basis of: 1) depth to water at selected geothermal wells to observe hydraulic head changes with time; and 2) groundwater chemistry at selected wells to indicate relative changes in temperature.

To develop a calibrated numerical model of the Moana geothermal system for investigation of development scenarios, the following additional data are needed:

1. detailed geological information on the geothermal aquifer;

2. measurements or estimates of hydraulic properties of the aquifer materials;

3. spatial distribution of thickness of layer between the geothermal and unconfined aquifers;

4. hydraulic conductivity of the layer between the two aquifers;

5. thermal conductivity of the layer between the two aquifers; 
6. spatial distribution of hydraulic heads in the overlying unconfined aquifer;

7. spatial distribution of temperatures in the overlying unconfined aquifer; and

8. location and rate of pumping in the geothermal wells.

The Moana geothermal system has extremely variable geology, hydrology, and thermal components. Thus, the development of a numerical model to reliably predict the behavior of the geothermal system requires an extensive data collection effort far in excess of that undertaken for this project. 


\section{REFERENCES}

Allis, R.G., 1981. "A Study of the Use of Downhole Heat Exchangers in the Moana Hot Water Area, Reno." Oregon Institute of Technology, Geo-Heat Center Report, pp. 35 .

Bateman, R.L. and R.B. Scheibach, 1975. "Evaluation of Geothermal Activity in the Truckee Meadows, Washoe County, Nevada." Nevada Bureau of Mines and Geology, Report 25, pp. 38.

Bingler, E.C., 1975. "Guidebook to the Quaternary Geology Along the Western Flank of the Truckee Meadows, Washoe County, Nevada." Nevada Bureau of Mines and Geology, Report 22, pp. 14.

Bohm, B. and R.L. Jacobson, 1981. "WATEQ DR, an Updated Version of WATEQ QF - A Computerized Chemical Model of Natural Waters." Water Resources Center, Desert Research Institute, Reno, NV, pp. 55.

Bonham, H.F., 1969. "Geology and Mineral Deposits of Washoe and Storey Counties, Nevada." Nevada Bureau of Mines and Geology, Bulletin 70, p. 31-53.

Bonham, H.F., Jr. and D.K. Rogers, 1983. "Geologic Map of the Mt. Rose NE 7.5 Minute Quadrangle." Nevada Bureau of Mines and Geology, Map no. 4Bg.

Chesley, M., W.A. McKay and S. McKenna, 1990. "The 1988 Truckee River Water Quality Monitoring Project Report.” Desert Research Institute, Water Resources Center, University of Nevada System, publication no. 41128, pp. 80.

Cohen, P., 1962. "Source of Sulfate in Ground Water of the Truckee Meadows Area, Nevada." U.S. Geol. Survey Prof. Paper, Vol. 450-C, Article 114, p. C131-C132.

Cohen, P. and O.J. Loeltz, 1964. "Evaluation of Hydrogeology and Hydrogeochemistry of Truckee Meadows Area, Washoe County, Nevada." U.S. Geol. Survey, Water Supply Paper 1779-S, pp. 63.

Ellis, A.J. and W.A.J. Mahon, 1964. "Natural Hydrothermal Systems and Experimental Hot-water/Rock Interactions." Geochemica et Cosmochemica Acta, Vol. 28, p. 1323-1357.

Ellis, A.J., 1970. "Quantitative Interpretation of Chemical Characteristics of Hydrothermal Systems." UN Symposium on the Development and Utilization of Geothermal Resources, Pisa, Proceedings, Geothermics - Special Issue 2, Vol. 2, Part 1, p. 516-528.

Flynn, T. and G. Ghusn, Jr., 1984. "Geologic and Hydrologic Research on the Moana Geothermal System, Washoe County, Nevada." Division of Earth Sciences, UNLV Report, pp. 148. 
Fournier, R.O., 1977. "Chemical Geothermometers and Mixing Models for Geothermal Systems." Geothermics, Vol. 5, p. 41-50.

Fournier, R.O. and A.H. Truesdell, 1973. "An Empirical Na-K-Ca Geothermometer for Natural Waters." Geochimica et Cosmochimica Acta, Vol. 37, p. 1255-1275.

Ghusn, G., Jr., 1982. "Baseline Data for Moana Geothermal Area." in Moderate-Temperature Geothermal Resources Assessment for Nevada: Area Specific Studies, Pumpernickel Valley, Carlin, and Moana: Trexler, Flynn, Koenig, Bell, and Ghusn. Division of Earth Sciences, University of Nevada, Las Vegas, pp. 145.

McCormack, Glenn, 1989. Personal Communication.

Mercer, J.W. and C.R. Faust, 1979. "Geothermal Reservoir Simulation: 3. Application of Liquid- and Vapor-Dominated Hydrothermal Modeling Techniques to Wairakei, New Zealand." Water Resources Research, Vol. 15, No. 3, p. 653-671.

NDEP (Nevada Division of Environmental Protection), 1989. Personal Communication.

Prucha, R.H., 1987. "Heat and Mass Transfer in the Klamath Falls, Oregon, Geothermal System." Earth Sciences Division, Lawrence Berkeley Laboratory, University of California, Berkeley, CA (LBL-23717), pp. 163.

REMCO, 1985. "Drilling, Completion, and Testing of Warren Estates Geothermal Well WE-2." Unpublished consultants report, pp. 40.

Sass, J.H. and E.A. Sammel, 1976. "Heat Flow Data and Their Relation to Observed Geothermal Phenomena Near Klamath Falls, Oregon." Journal of Geophysical Research, Vol. 81, No. 26, p. 4863-4868.

Scheibach, R.B., 1975. "Geothermal Occurrences in Truckee Meadows, Washoe County, Nevada." University of Nevada, Reno, unpublished Masters thesis, pp. 74.

Thompson, G.A. and D.E. White, 1964. "Regional Geology of the Steamboat Springs Area, Washoe County, Nevada." U.S. Geol. Survey Prof. Paper 458-A, pp. 52.

Voss, C.I., 1984. "A Finite-Element Simulation Model for Saturated-Unsaturated Fluid-Density-Dependent Groundwater Flow with Energy Transport or Chemically-Reactive Single-Species Solute Transport." U.S. Geological Survey WaterResources Investigations Report 84-4369.

Wright, P.M. and G. Culver, 1984. "Nature of Geothermal Resources" Chapter 3 in Geothermal Direct Use Engineering and Design Guidebook, P.J. Lienau and B.C. Lunis, editors, p. 23-44. 


\section{APPENDIX I}

\section{Well Types}




\section{WELL TYPES}

Well

Number

1 Location:

1435 Huntington

Well Construction: $\quad 8$ " diameter steel casing

Heat Extraction Method: Single loop downhole heat exchanger

Type of Pump:

Submersible pump

2 Location:

4280 Plumas

Well Construction:

8 " diameter steel casing

Heat Extraction Method:

Double coil downhole exchanger

Type of Pump:

Jet pump

3 Location:

1150 Sweetwater

Well Construction:

6" diameter steel casing

Heat Extraction Method:

Downhole heat exchanger

Type of Pump:

Jet pump

4 Location:

1275 Sweetwater House

Well Construction:

$8^{\prime \prime}$ diameter steel casing

Heat Extraction Method:

Downhole heat exchanger

Type of Pump:

Submersible pump

5 Location:

1184 Sweetwater

Well Construction:

8 " diameter steel casing

Heat Extraction Method:

Downhole heat exchanger

Type of Pump:

Submersible pump

6 Location:

1160 W. Peckham

Well Construction:

6" diameter steel casing

Heat Extraction Method:

Downhole heat exchanger

Type of Pump:

Jet pump

7 Location:

3915 Nut Tree

Well Construction:

6" diameter steel casing

Heat Extraction Method:

Type of Pump:

Downhole heat exchanger

Jet pump

8 Location:

3850 Plumas

Well Construction:

8 " diameter steel casing

Heat Extraction Method:

Type of Pump:

Downhole heat exchanger

Jet pump 
9 Location:

Well Construction:

Heat Extraction Method:

Type of Pump:

10 Location:

Well Construction:

Heat Extraction Method:

Type of Pump:

11 Location:

Well Construction:

Heat Extraction Method:

Type of Pump:

12 Location:

Well Construction:

Heat Extraction Method:

Type of Pump:

13 Location:

Well Construction:

Heat Extraction Method:

Type of Pump:

14 Location:

Well Construction:

Heat Extraction Method:

Type of Pump:

15 Location:

Well Construction:

Heat Extraction Method:

Type of Pump:

16 Location:

Well Construction:

Heat Extraction Method:

Type of Pump:

17 Location:

Well Construction:

Heat Extraction Method:

Type of Pump:
4220 Swanson

8 " diameter steel casing

Downhole heat exchanger

Jet pump

1680 Manzanita

8 " diameter steel casing

Downhole heat exchanger

Jet pump

4305 Plumas

$8^{\prime \prime}$ diameter steel casing

Downhole heat exchanger

No pump

1275 Sweetwater Pool

$8^{\prime \prime}$ diameter steel casing

Downhole heat exchanger

No pump

1155 Yates

8" diameter steel casing

Downhole heat exchanger galvanized steel

No pump

1195 Manzanita

$8^{\prime \prime}$ diameter steel casing

Downhole heat exchanger

No pump

2020 Manzanita

$8^{\prime \prime}$ diameter steel casing

Downhole heat exchanger

No pump

4000 Jasper

8" diameter steel casing

Extractive

Submersible pump

2075 Lakeside

8 " diameter steel casing

Extractive

Submersible pump 
Location:

Well Construction:

Heat Extraction Method:

Type of Pump:

19 Location:

Well Construction:

Heat Extraction Method:

Type of Pump:

20 Location:

Well Construction:

Heat Extraction Method:

Type of Pump:

21 Location:

Well Construction:

Heat Extraction Method:

Type of Pump:

22 Location:

Well Construction:

Heat Extraction Method:

Type of Pump:

23 Location:

Well Construction:

Heat Extraction Method:

Type of Pump:

24 Location:

Well Construction:

Heat Extraction Method:

Type of Pump:

25 Location:

Well Construction:

Heat Extraction Method:

Type of Pump:

26 Location:

Well Construction:

Heat Extraction Method:

Type of Pump:
1100 Moana

8 " diameter steel casing

Extractive

Submersible pump

1301 Manzanita Lane

6" diameter steel casing

Unused downhole heat exchanger

No pump

1195 Yates

8 " diameter steel casing

Unused downhole heat exchanger

No pump

1880 Meadowview

8 " diameter steel casing

No heating system

No pump

4235 Lakeside

6 " diameter steel casing

Unused

No pump

2750 Plumas

12 " diameter steel casing

Unused

No pump

1975 Greenfield

8 " diameter steel casing

Unused

No pump

Manzanita Park

2 " diameter steel casing

Monitoring well

No pump

Horseman's Park

2 " diameter steel casing

Monitoring well

No pump 


\section{APPENDIX II}

\section{Heating and Nonheating Temperature With Depth Profiles for All Wells in the Study Group}




\section{WELL 1 TEMPERATURE-DEPTH PROFILES}

Heating and Nonheating Data, Heat Exchanger, Pumped

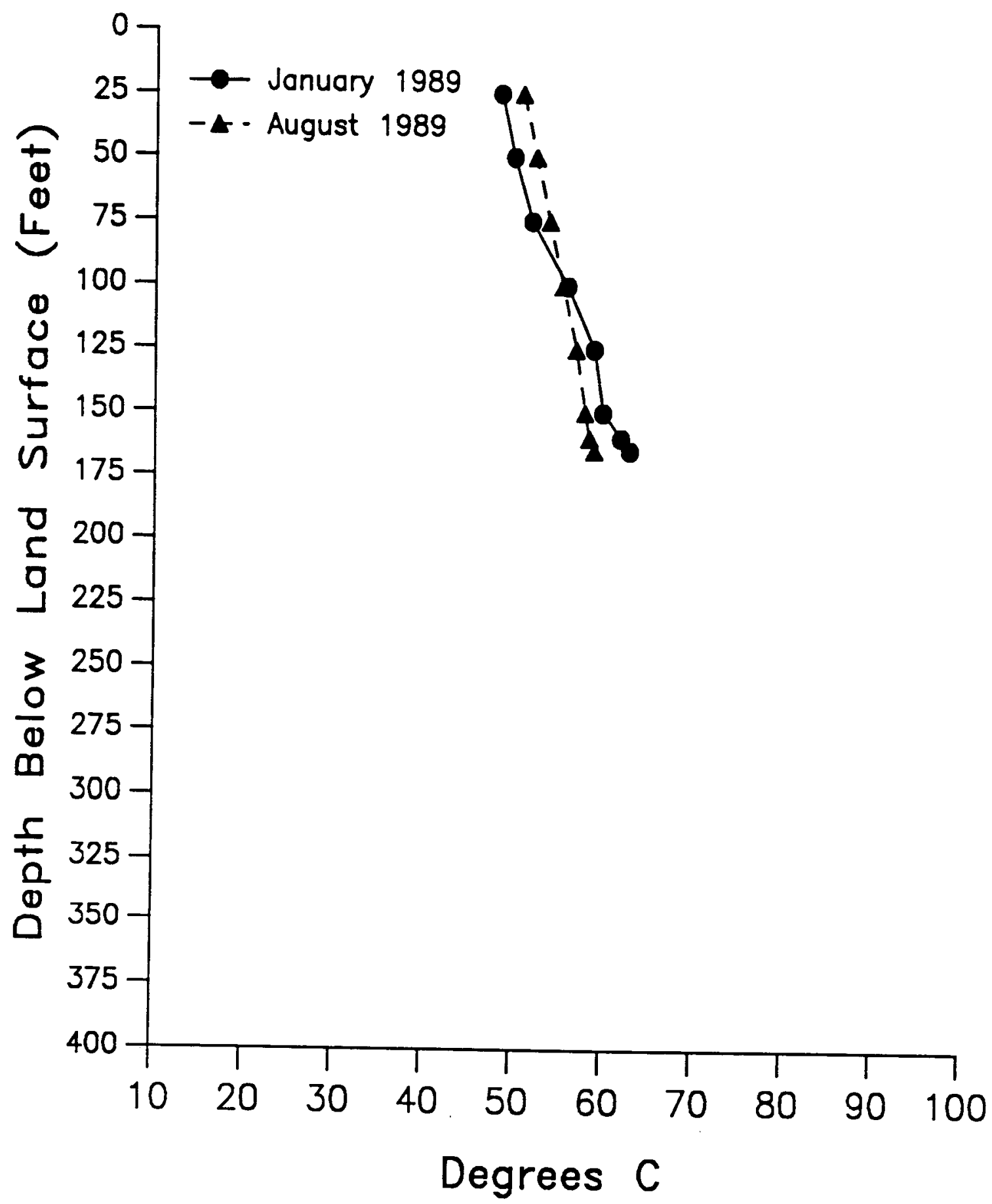




\section{WELL 2 TEMPERATURE-DEPTH PROFILES}

Heating and Nonheating Data, Heat Exchanger, Pumped

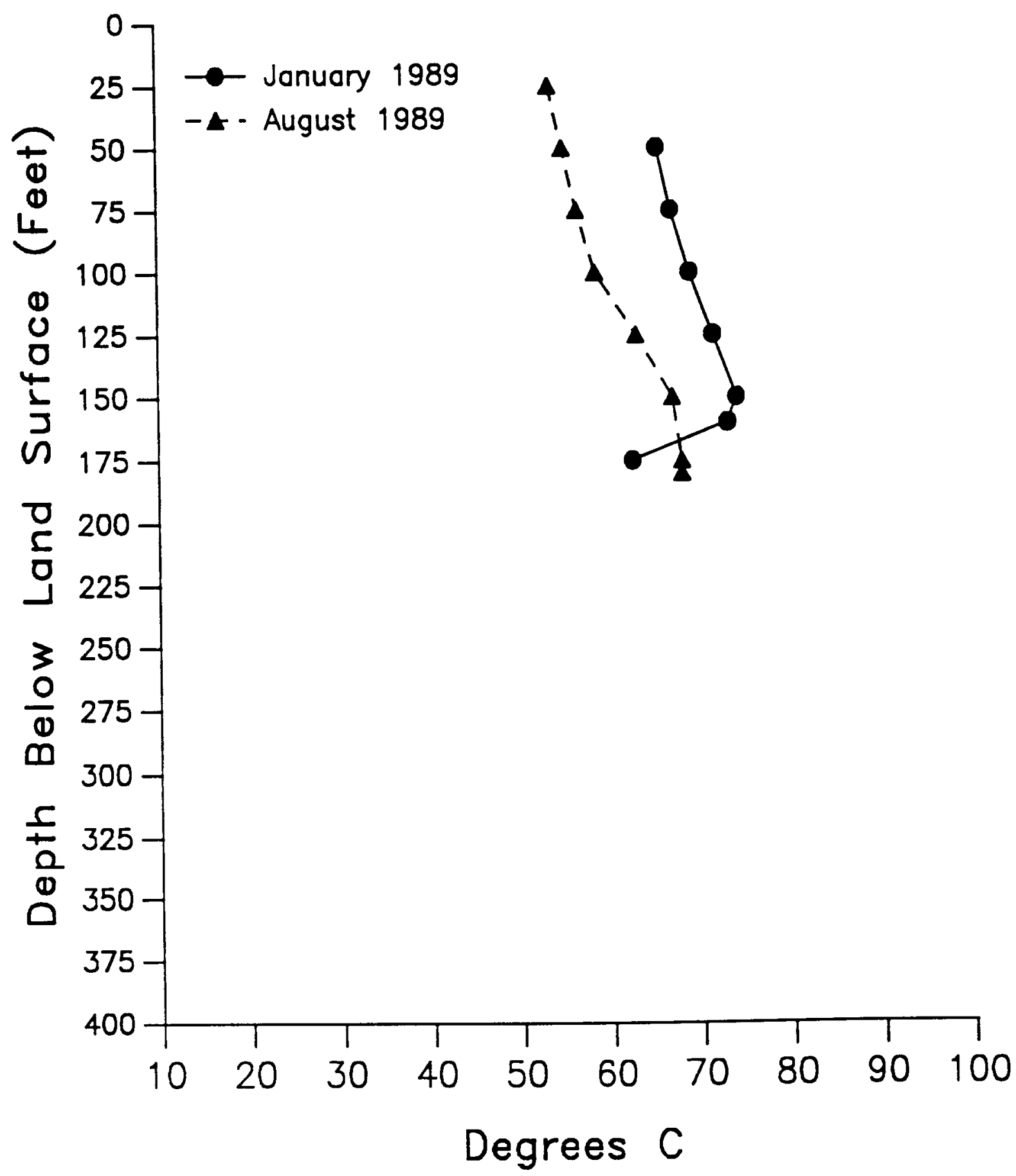




\section{WELL 3 TEMPERATURE-DEPTH PROFILES}

Heating and Nonheating Data, Heat Exchanger, Pumped

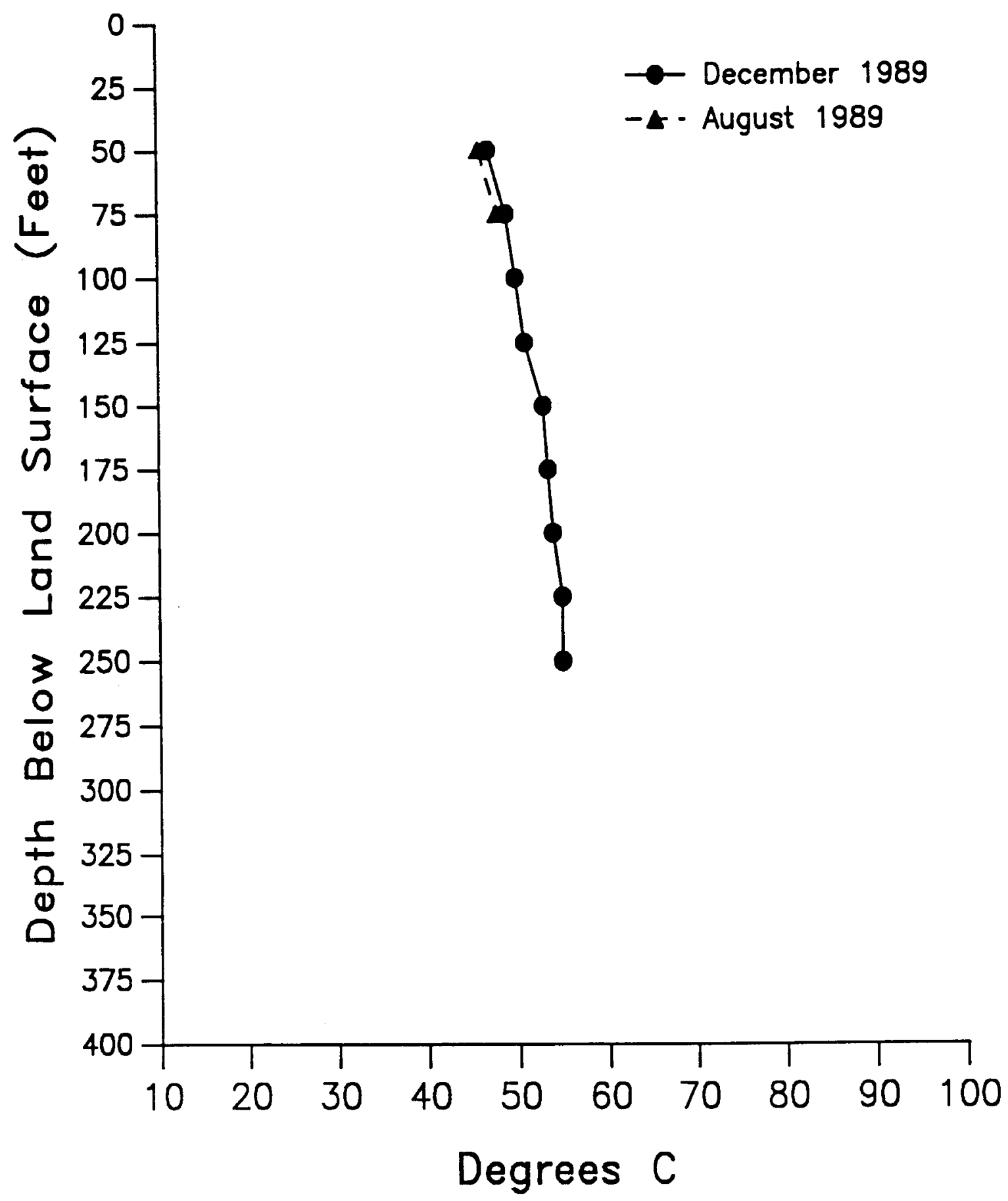




\section{WELL 4 TEMPERATURE-DEPTH PROFILES}

Heating and Nonheating Data, Heat Exchanger, Pumped

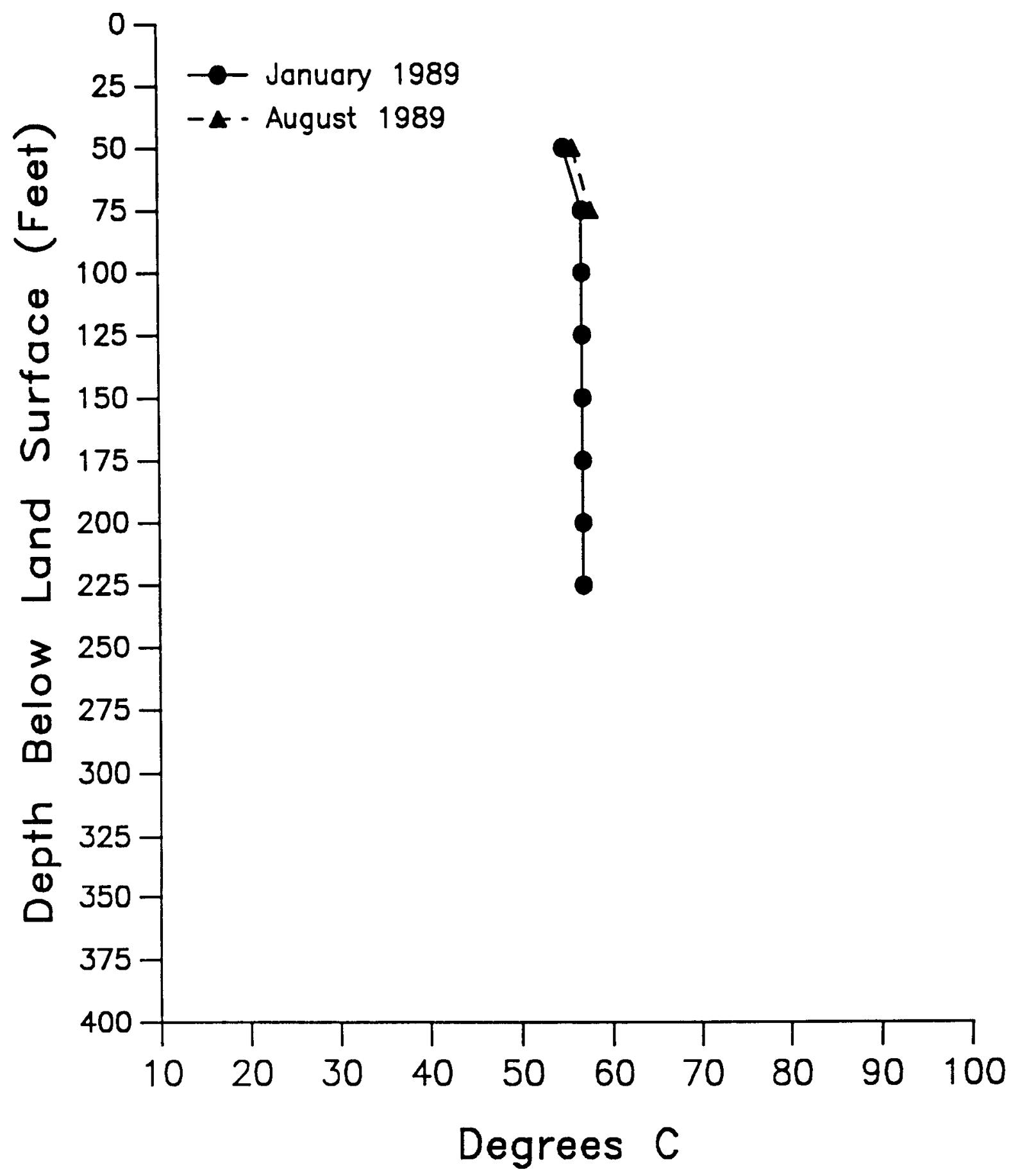




\section{WELL 5 TEMPERATURE-DEPTH PROFILES}

Heating and Nonheating Data, Heat Exchanger, Pumped

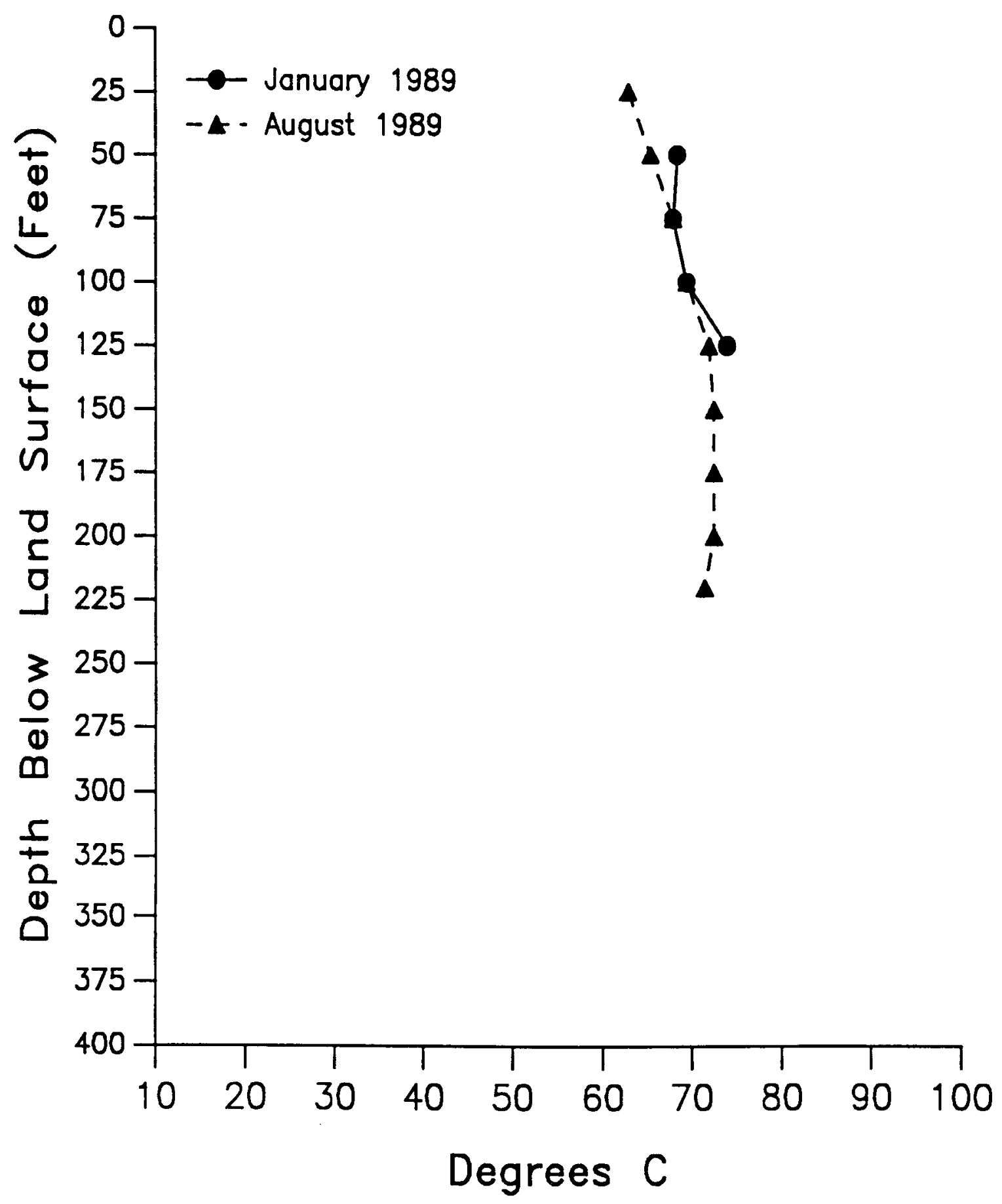




\section{WELL 6 TEMPERATURE-DEPTH PROFILES}

Heating and Nonheating Data, Heat Exchanger, Pumped

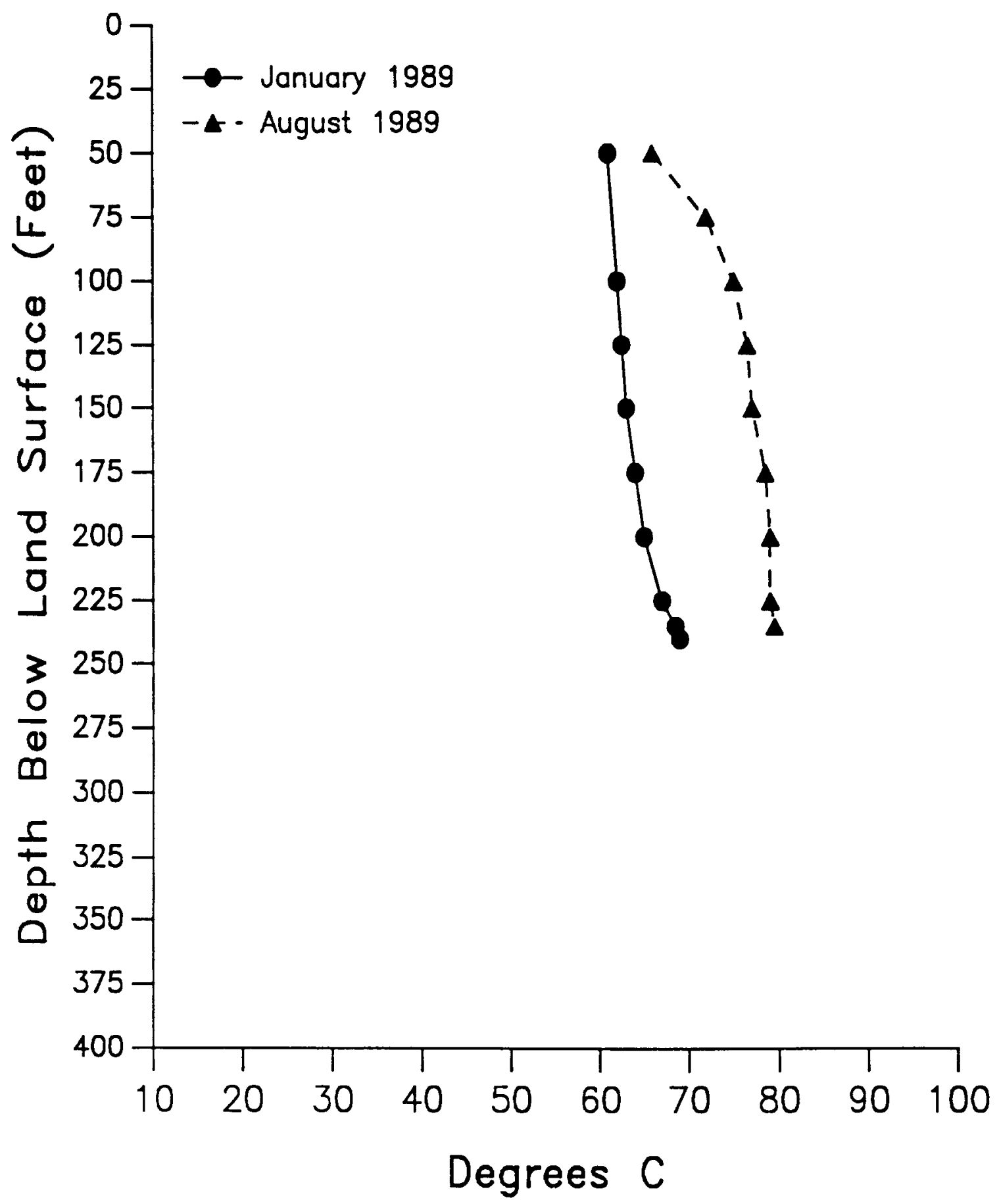




\section{WELL 7 TEMPERATURE-DEPTH PROFILES}

Heating and Nonheating Data, Heat Exchanger, Pumped

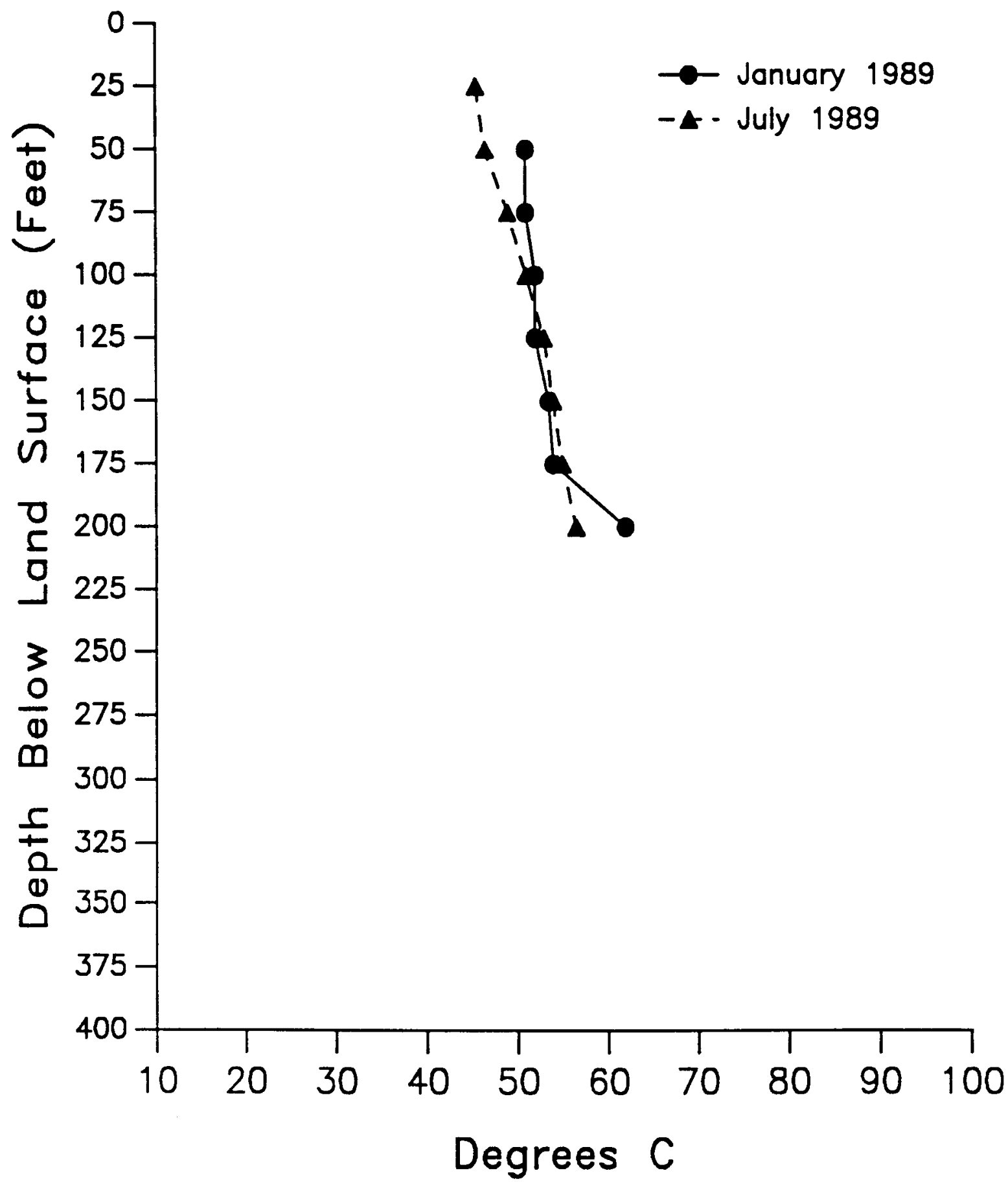




\section{WELL 8 TEMPERATURE-DEPTH PROFILES}

Heating and Nonheating Data, Heat Exchanger, Pumped

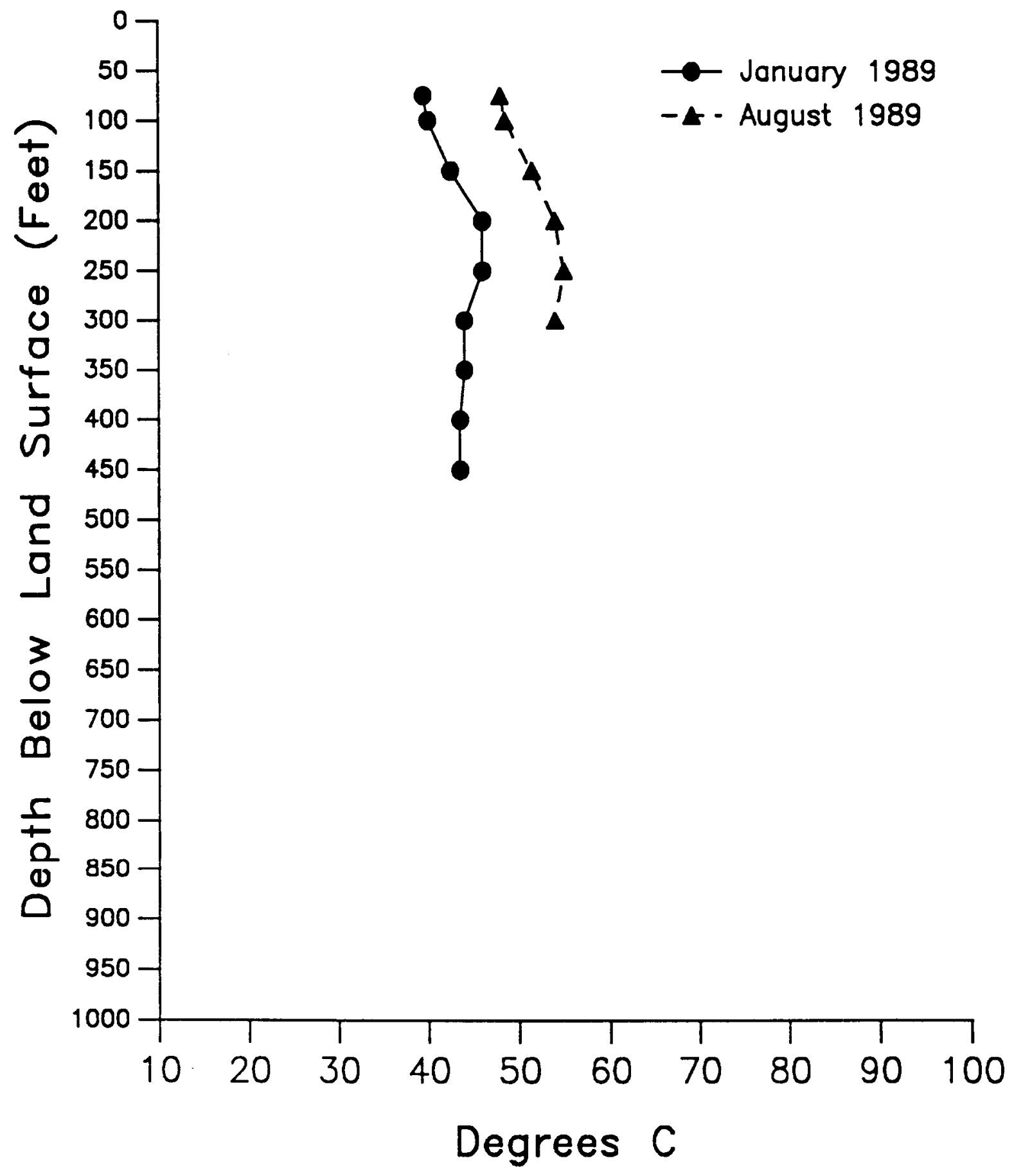




\section{WELL 9 TEMPERATURE-DEPTH PROFILES}

Heating and Nonheating Data, Heat Exchanger, Pumped

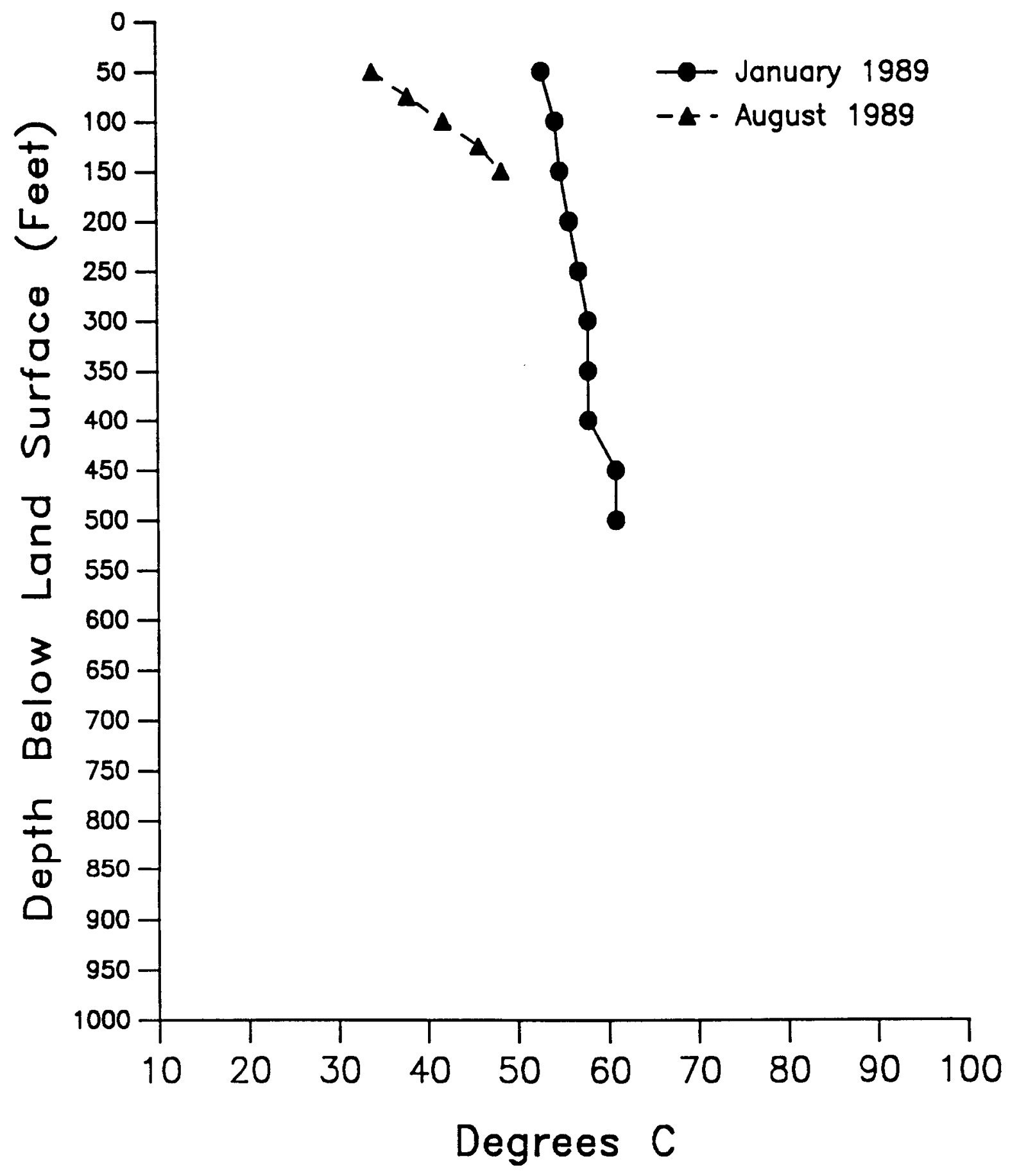




\section{WELL 10 TEMPERATURE-DEPTH PROFILES}

Heating and Nonheating Data, Heat Exchanger, Pumped

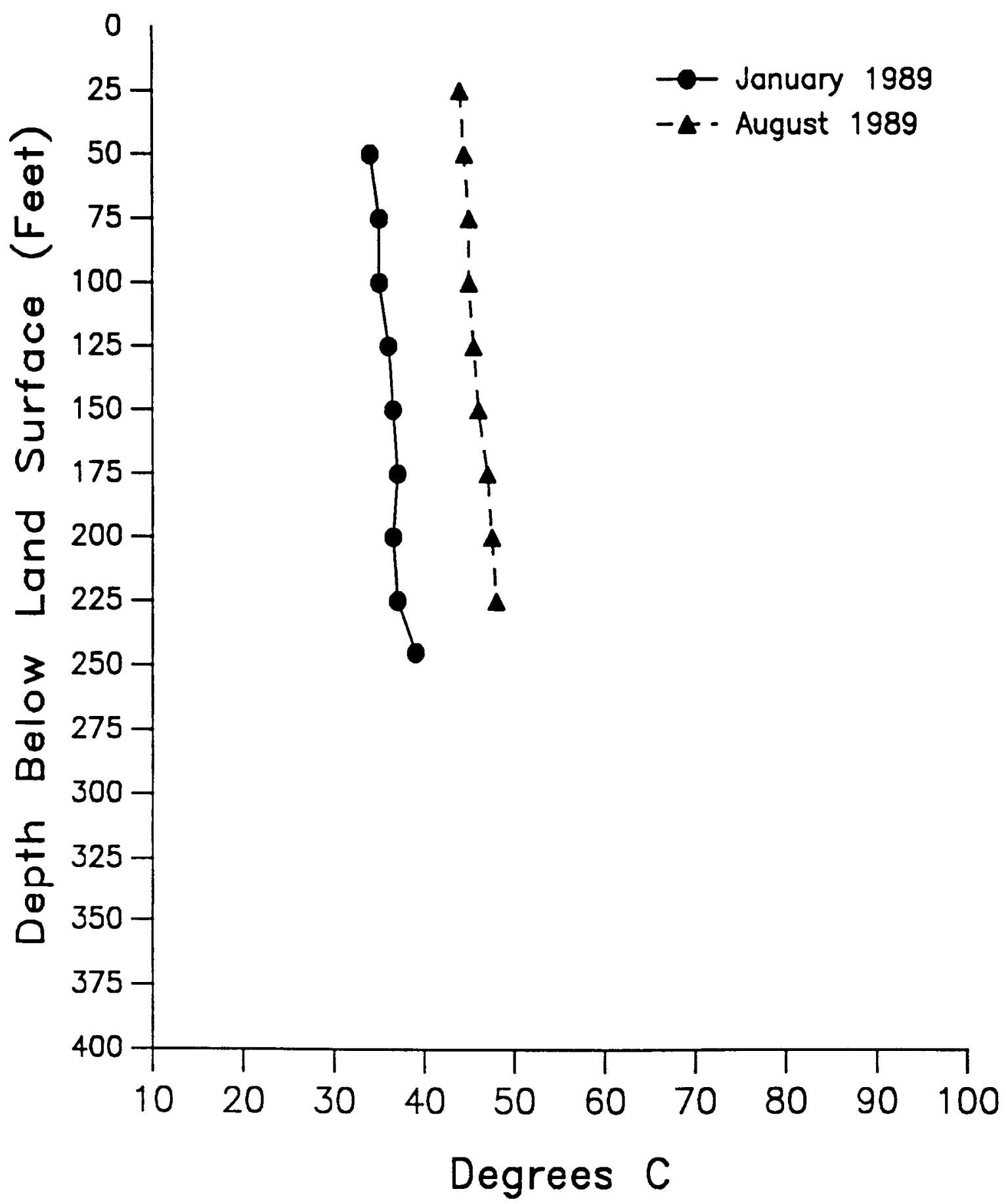




\section{WELL 11 TEMPERATURE-DEPTH PROFILES}

Heating and Nonheating Data, Heat Exchanger, No Pump

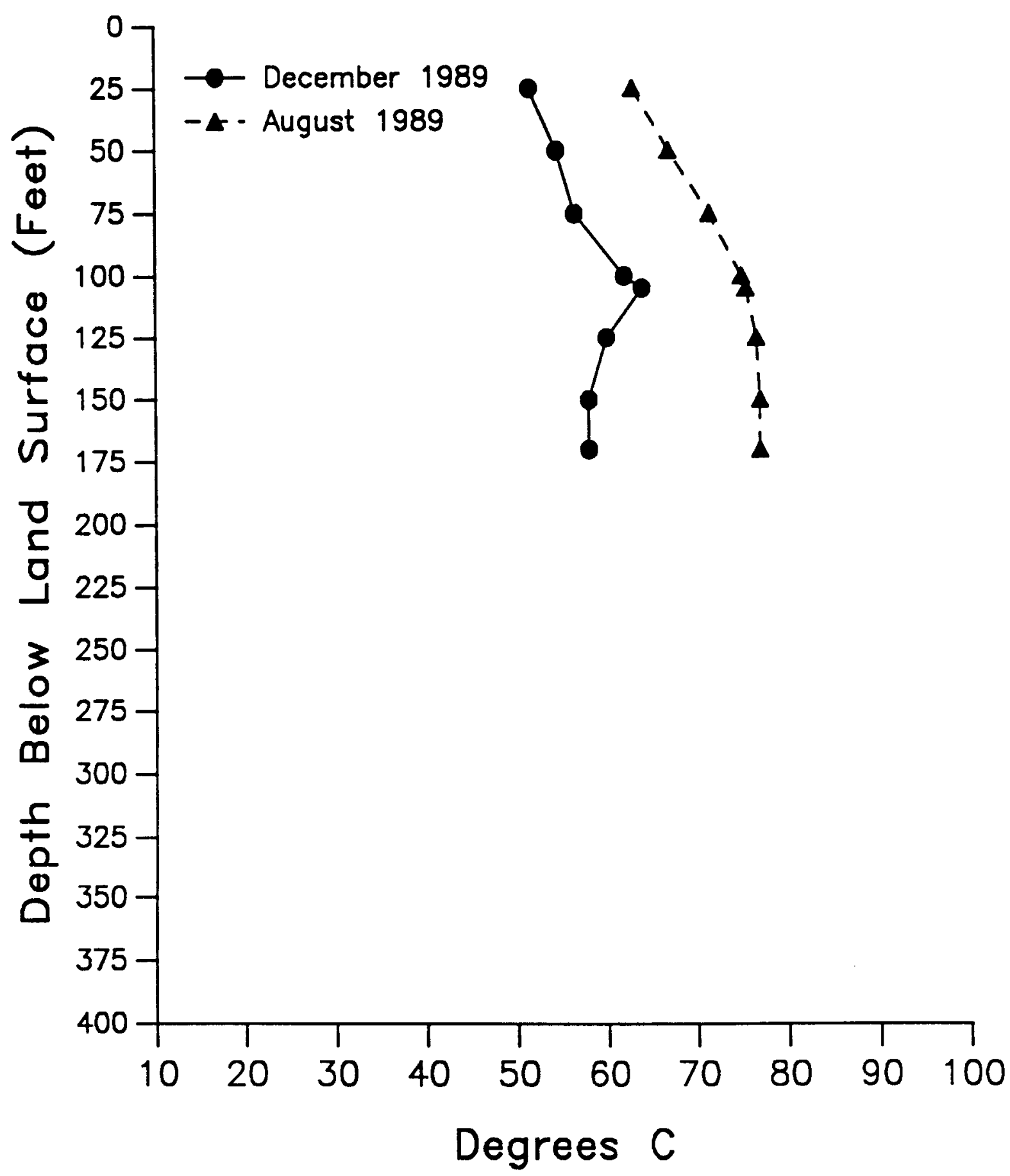




\section{WELL 12 TEMPERATURE-DEPTH PROFILES}

Heating and Nonheating Data, Heat Exchanger, No Pump

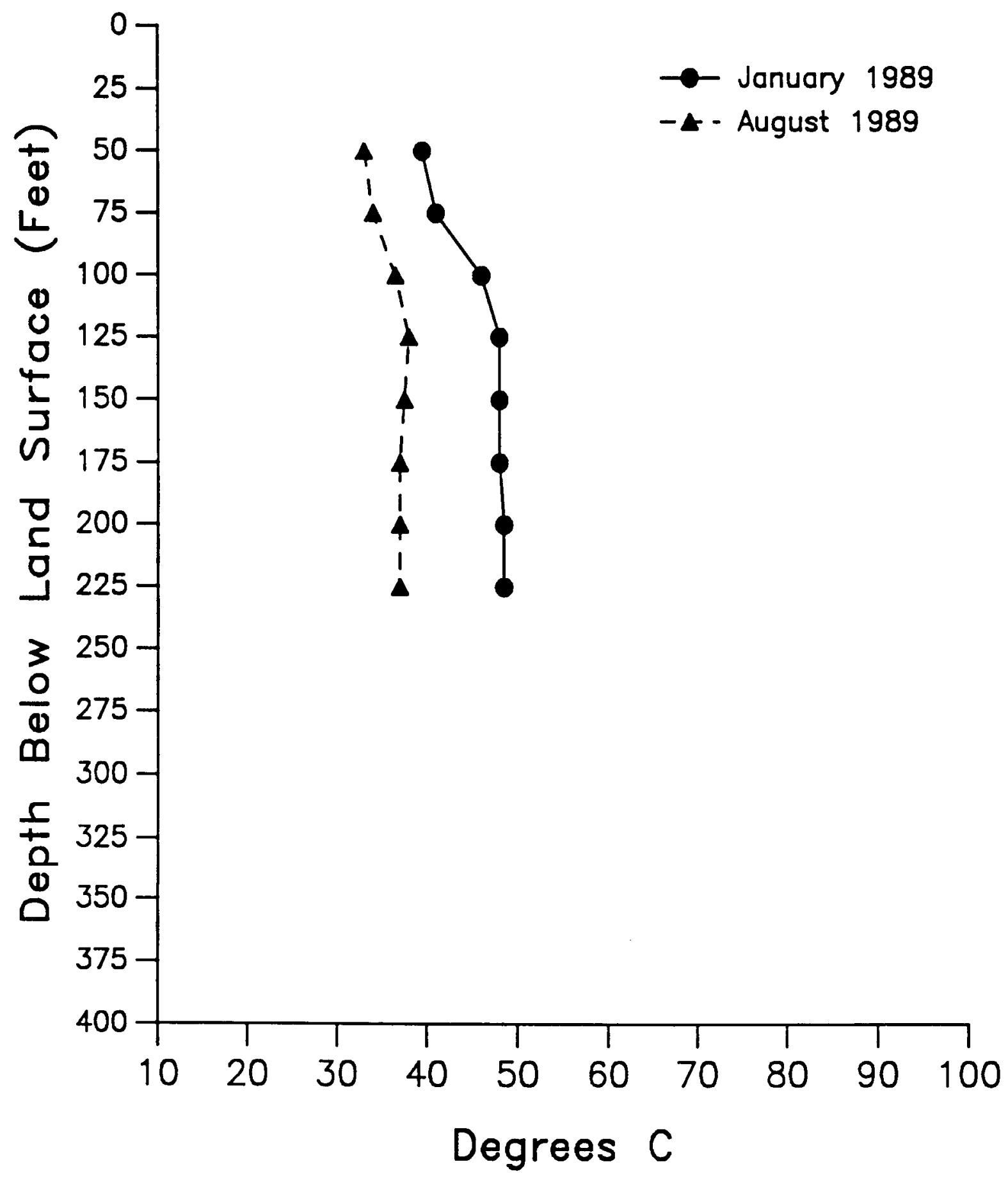




\section{WELL 13 TEMPERATURE-DEPTH PROFILES}

\section{Heating and Nonheating Data, Heat Exchanger, No Pump}

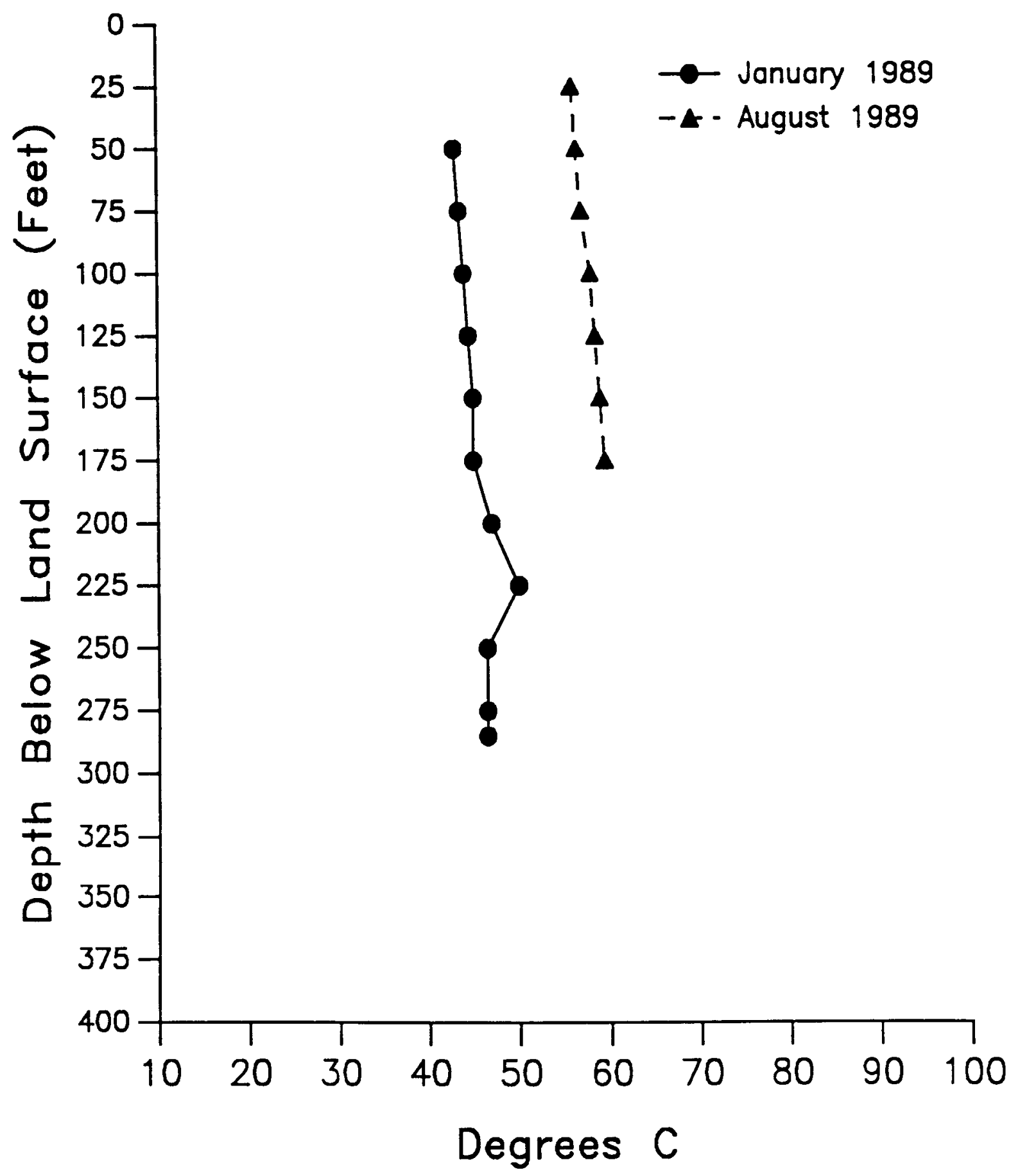




\section{WELL 14 TEMPERATURE-DEPTH PROFILES}

Heating and Nonheating Data, Heat Exchanger, No Pump

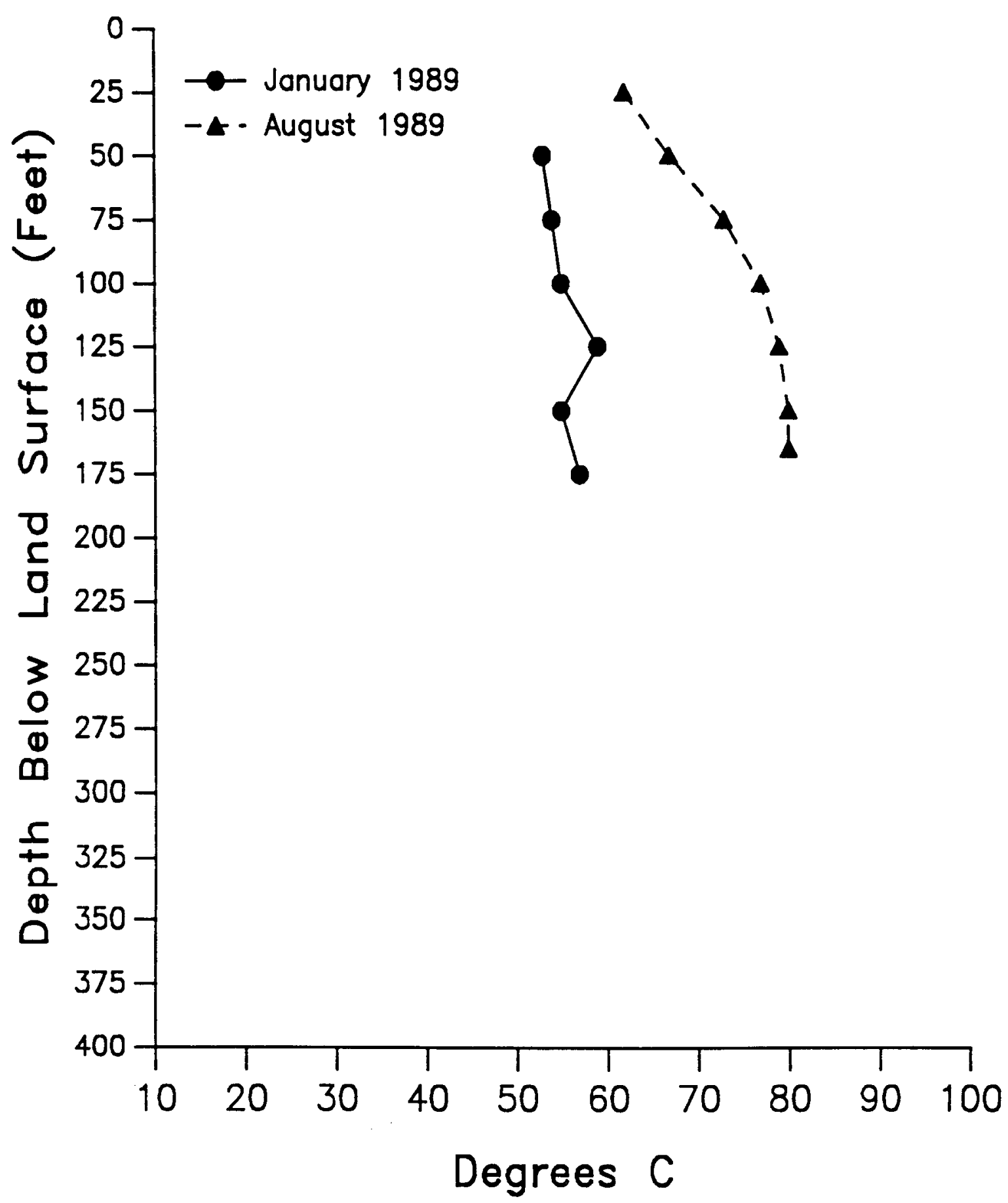




\section{WELL 15 TEMPERATURE-DEPTH PROFILES}

Heating and Nonheating Data, Heat Exchanger, No Pump

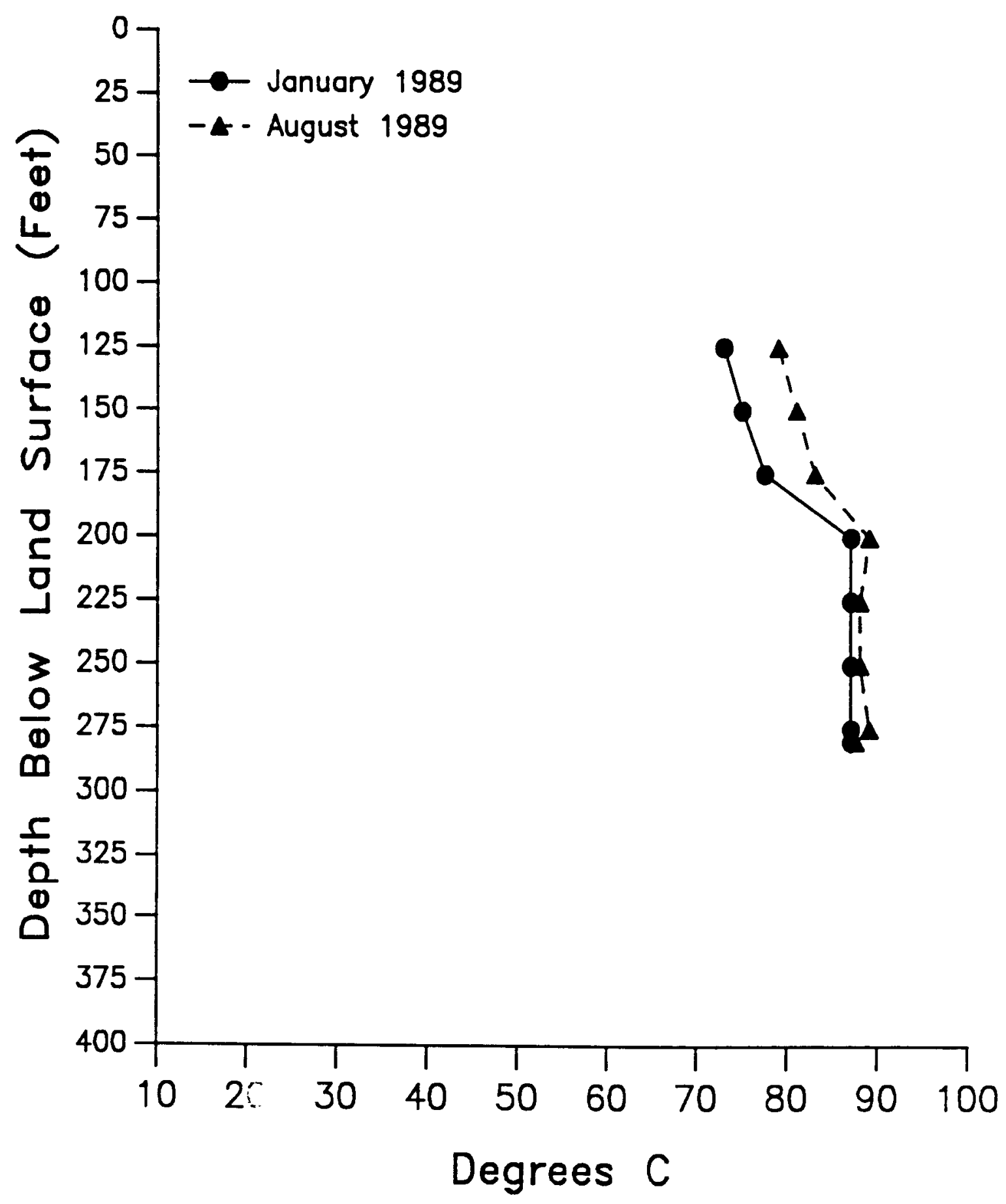




\section{WELL 16 TEMPERATURE-DEPTH PROFILES}

Heating and Nonheating Data, Extractive Well

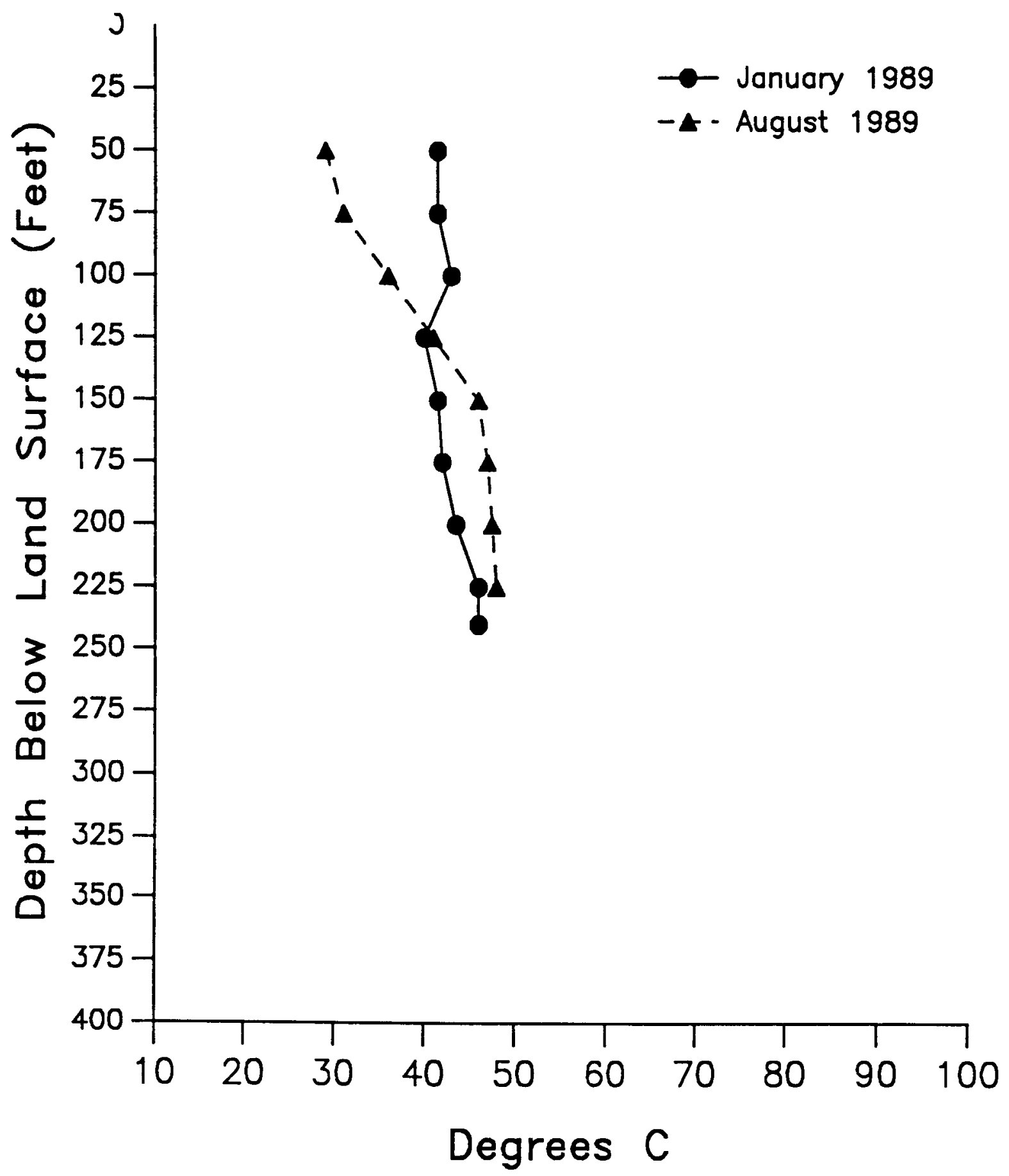




\section{WELL 17 TEMPERATURE-DEPTH PROFILES}

Heating and Nonheating Data, Extractive Well

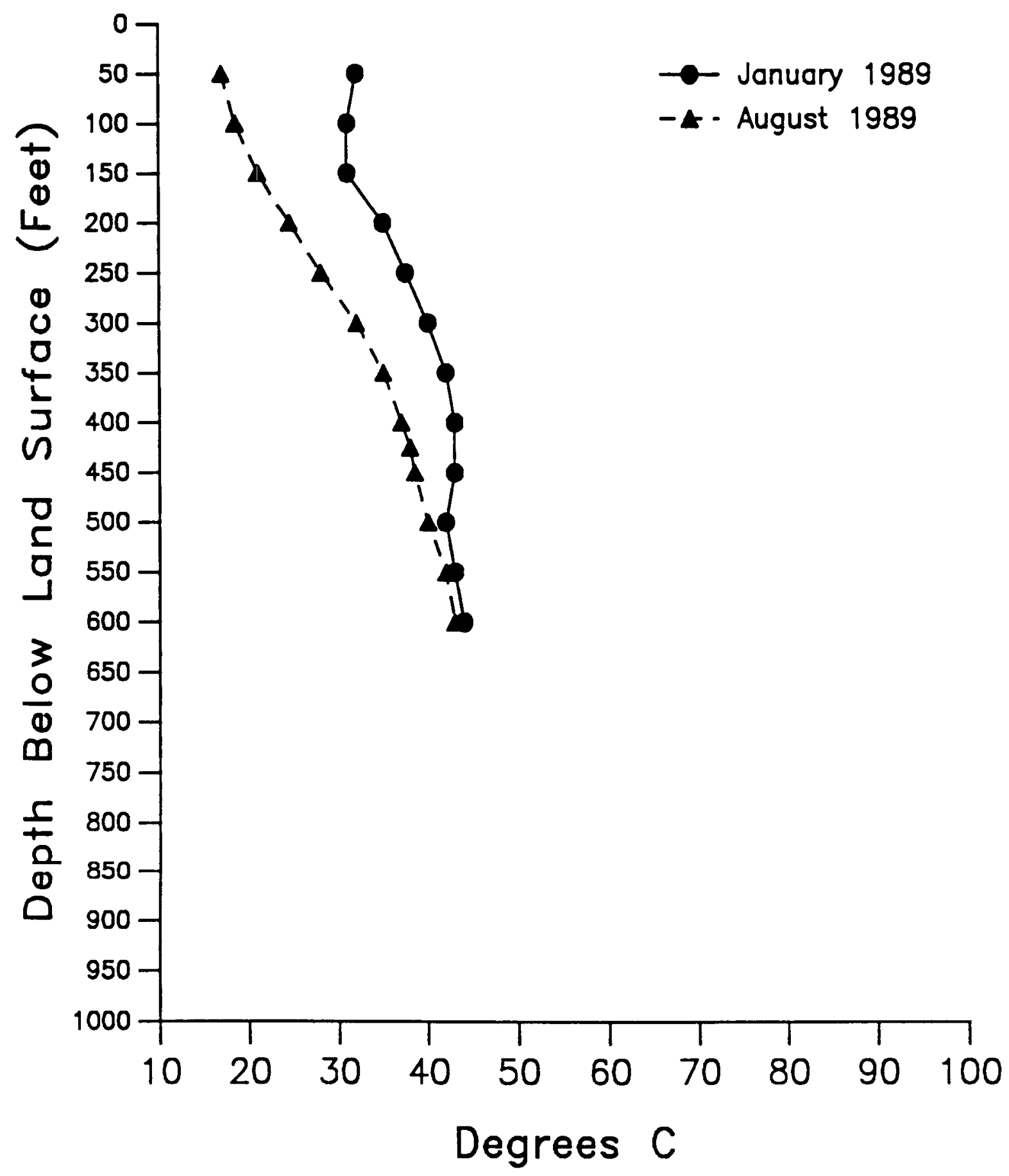




\section{WELL 18 TEMPERATURE-DEPTH PROFILES}

Heating and Nonheating Data, Extractive Well

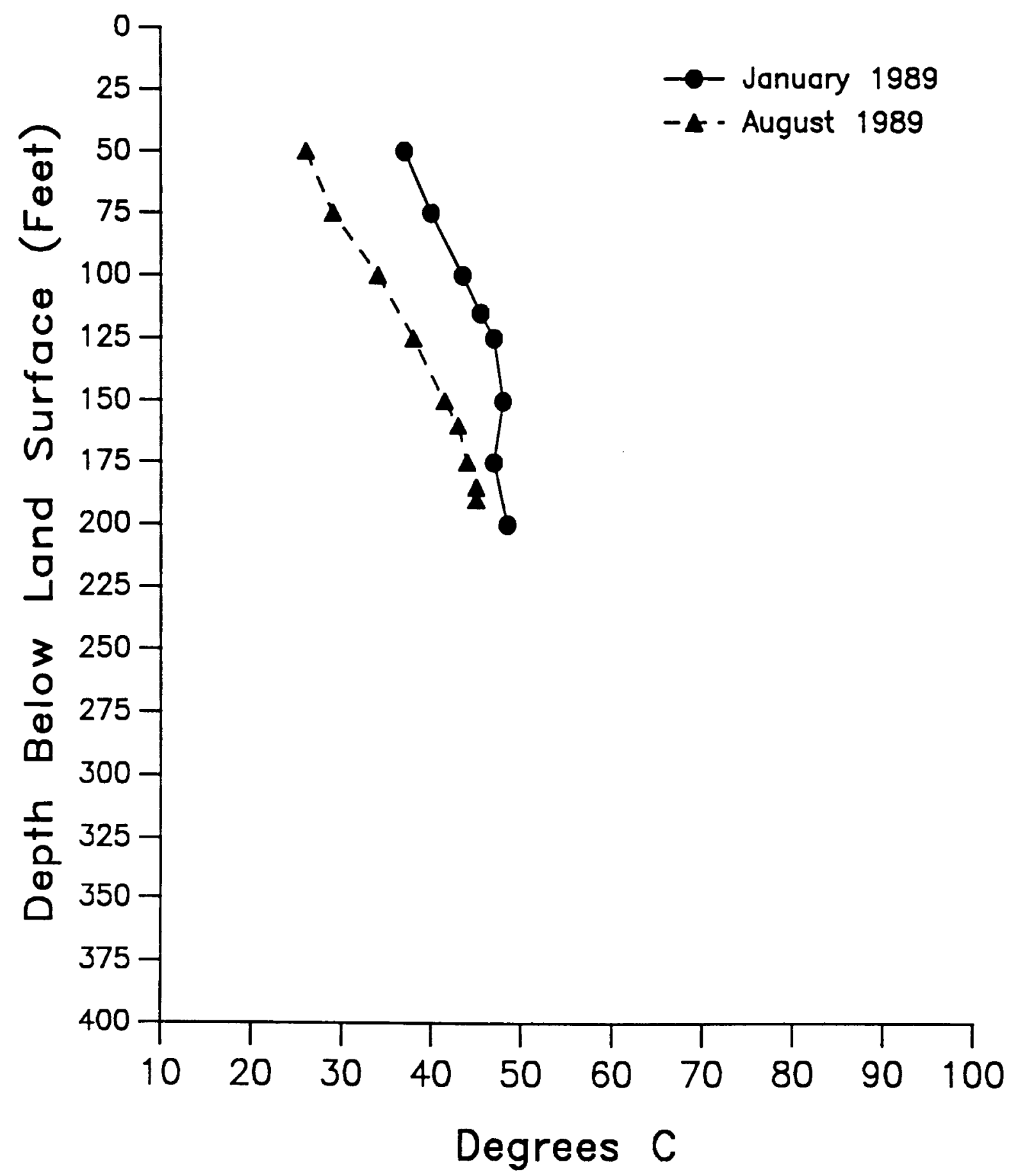




\section{WELL 19 TEMPERATURE-DEPTH PROFILES}

Heating and Nonheating Data, Unused Domestic Well

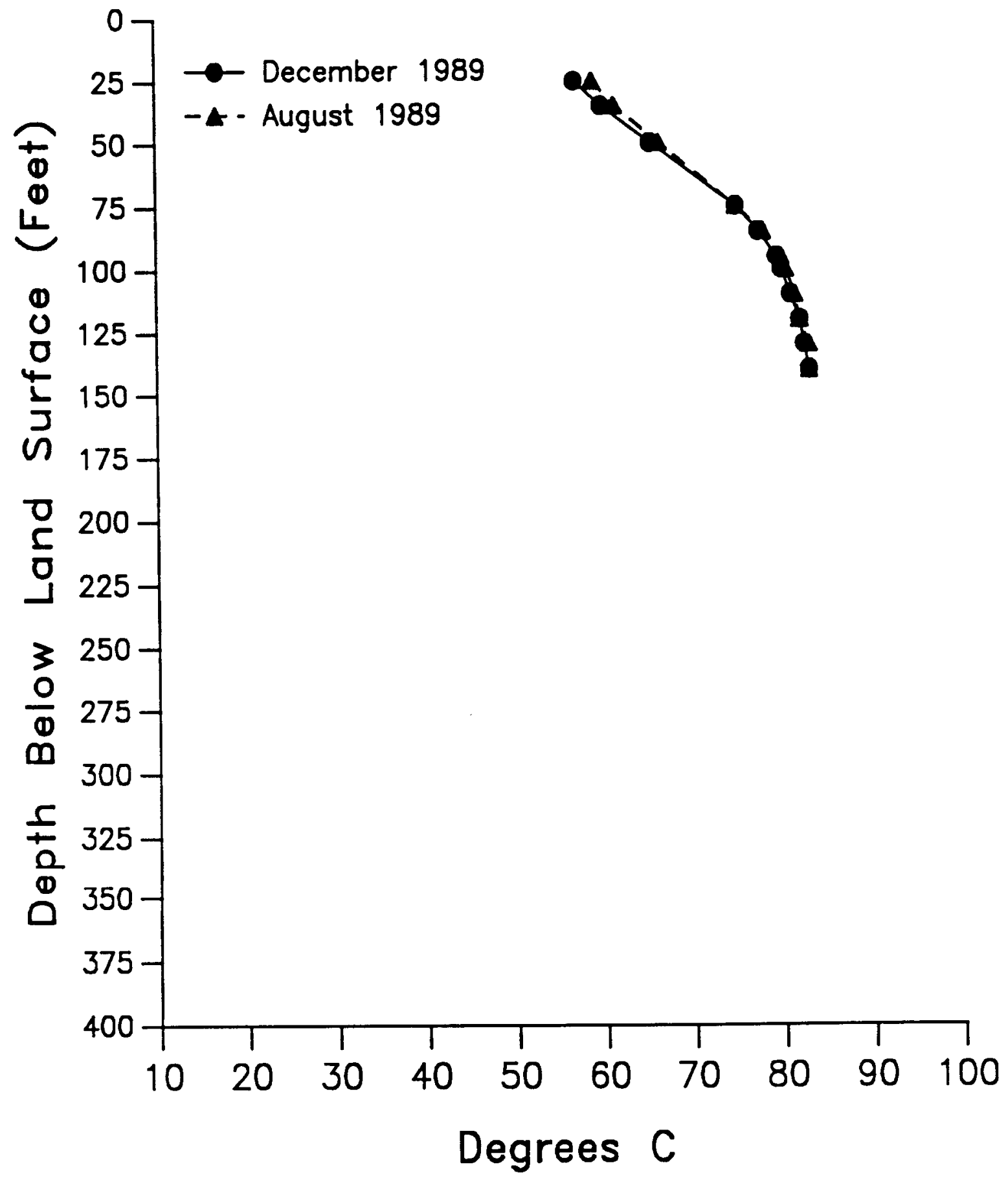




\section{WELL 20 TEMPERATURE-DEPTH PROFILES}

Heating and Nonheating Data, Unused Domestic Well

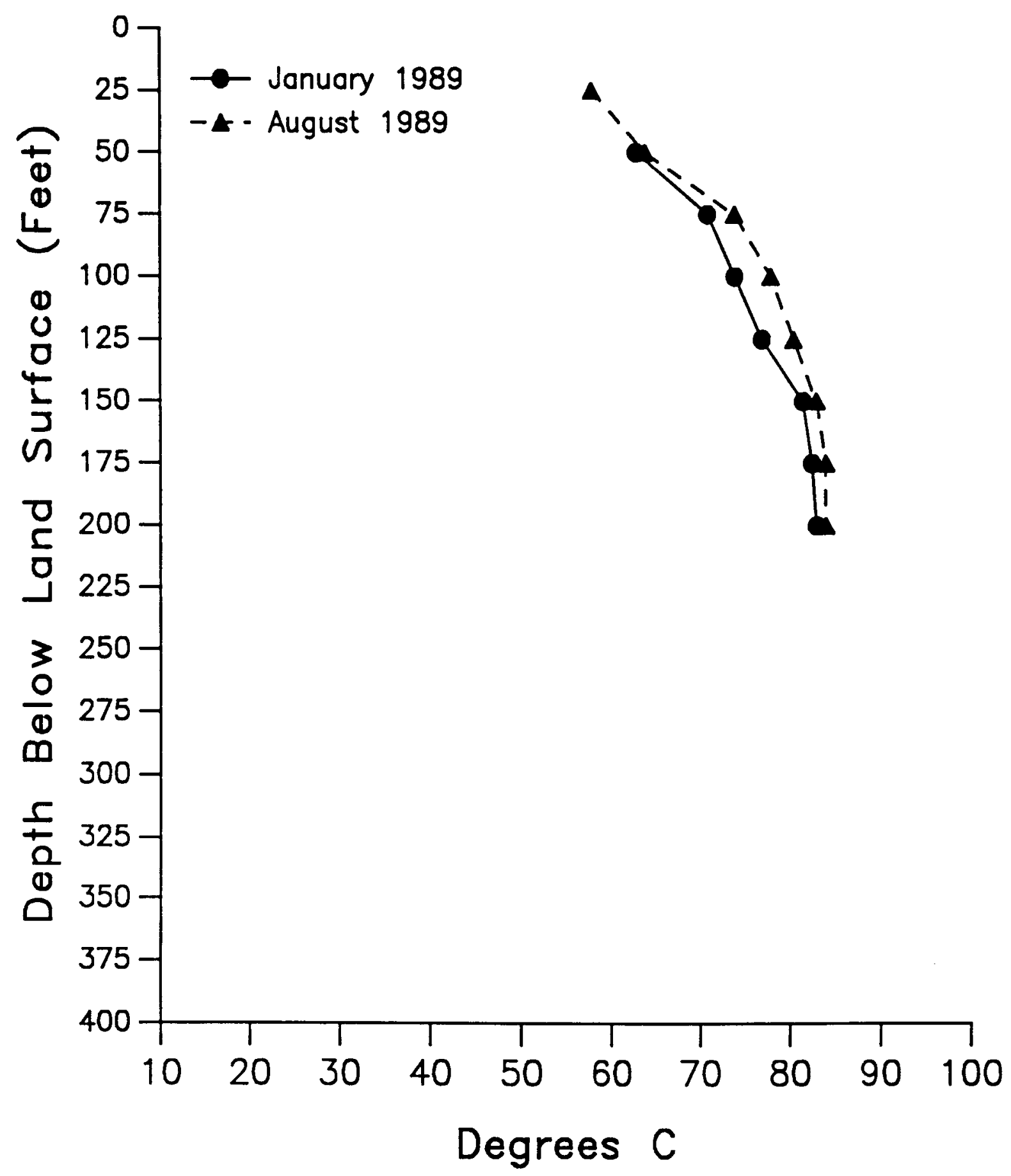




\section{WELL 21 TEMPERATURE-DEPTH PROFILES}

Heating and Nonheating Data, Unused Domestic Well

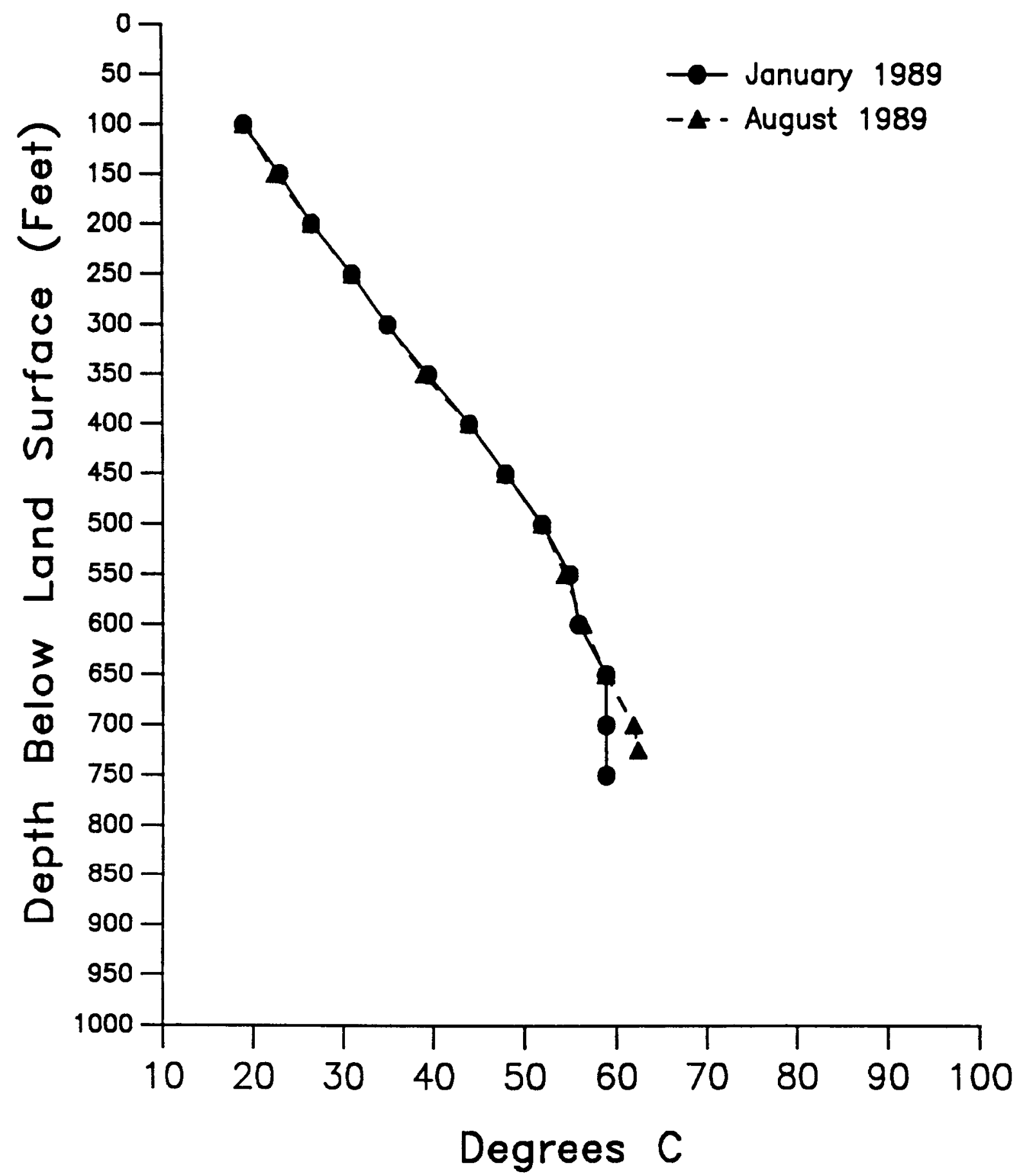




\section{WELL 22 TEMPERATURE-DEPTH PROFILES}

Heating and Nonheating Data, Unused Domestic Well

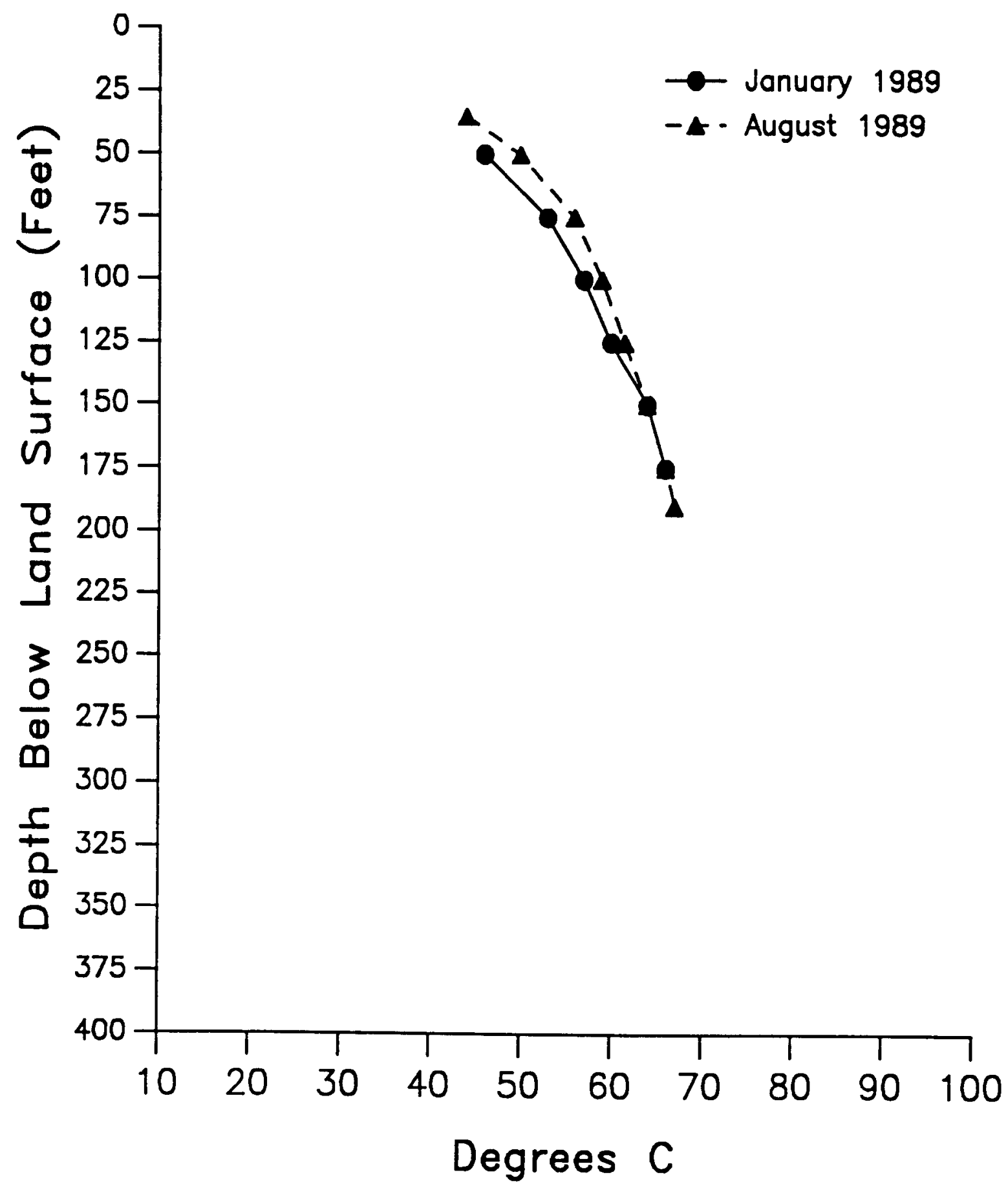




\section{WELL 23 TEMPERATURE-DEPTH PROFILES}

\section{Heating and Nonheating Data, Unused Commercial Well}

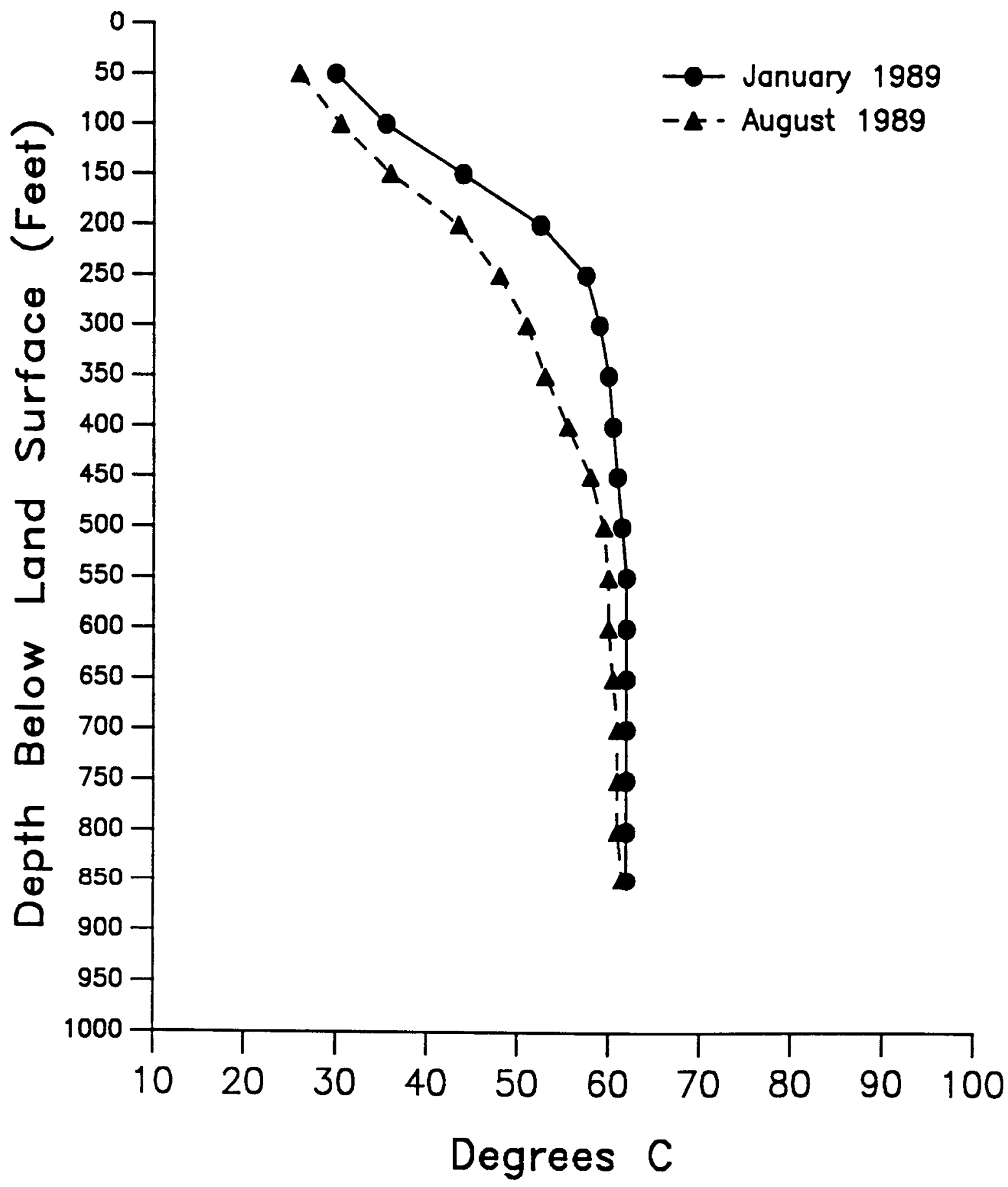




\section{WELL 24 TEMPERATURE-DEPTH PROFILES}

Heating and Nonheating Data, Unused Domestic Well

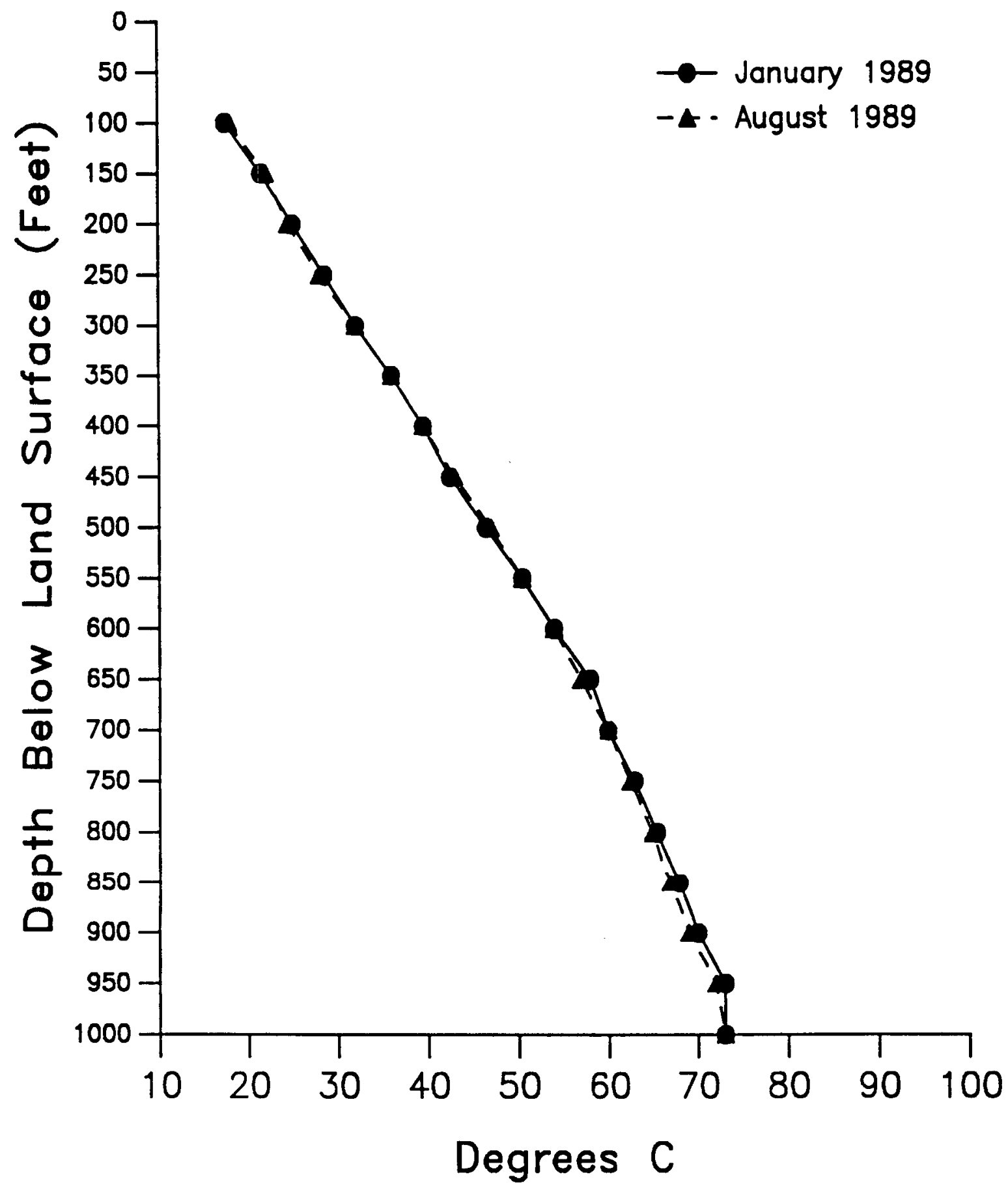




\section{WELL 25 TEMPERATURE-DEPTH PROFILES \\ Heating and Nonheating Data, Monitoring Well}

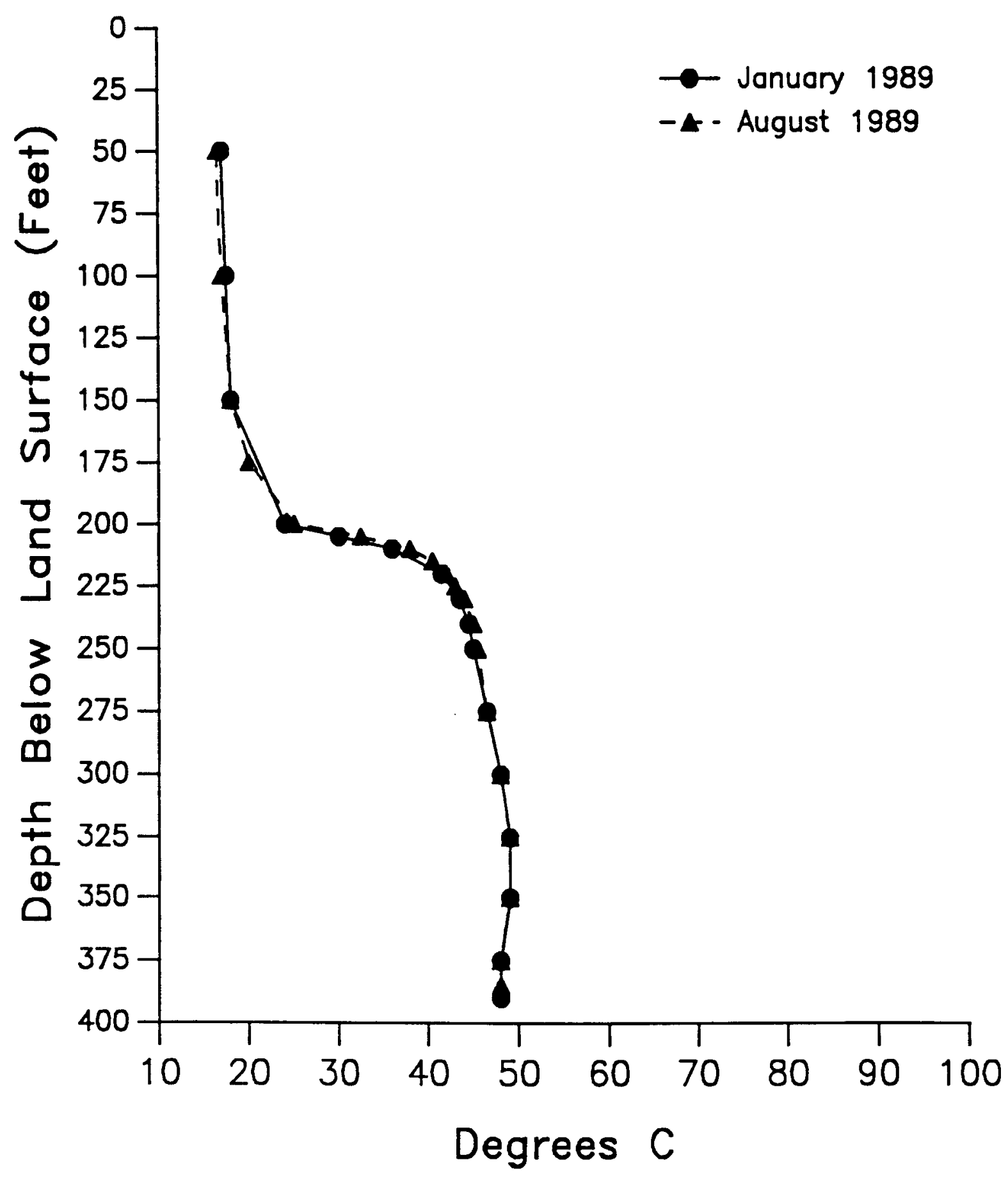




\section{WELL 26 TEMPERATURE-DEPTH PROFILES \\ Heating and Nonheating Data, Monitoring Well}

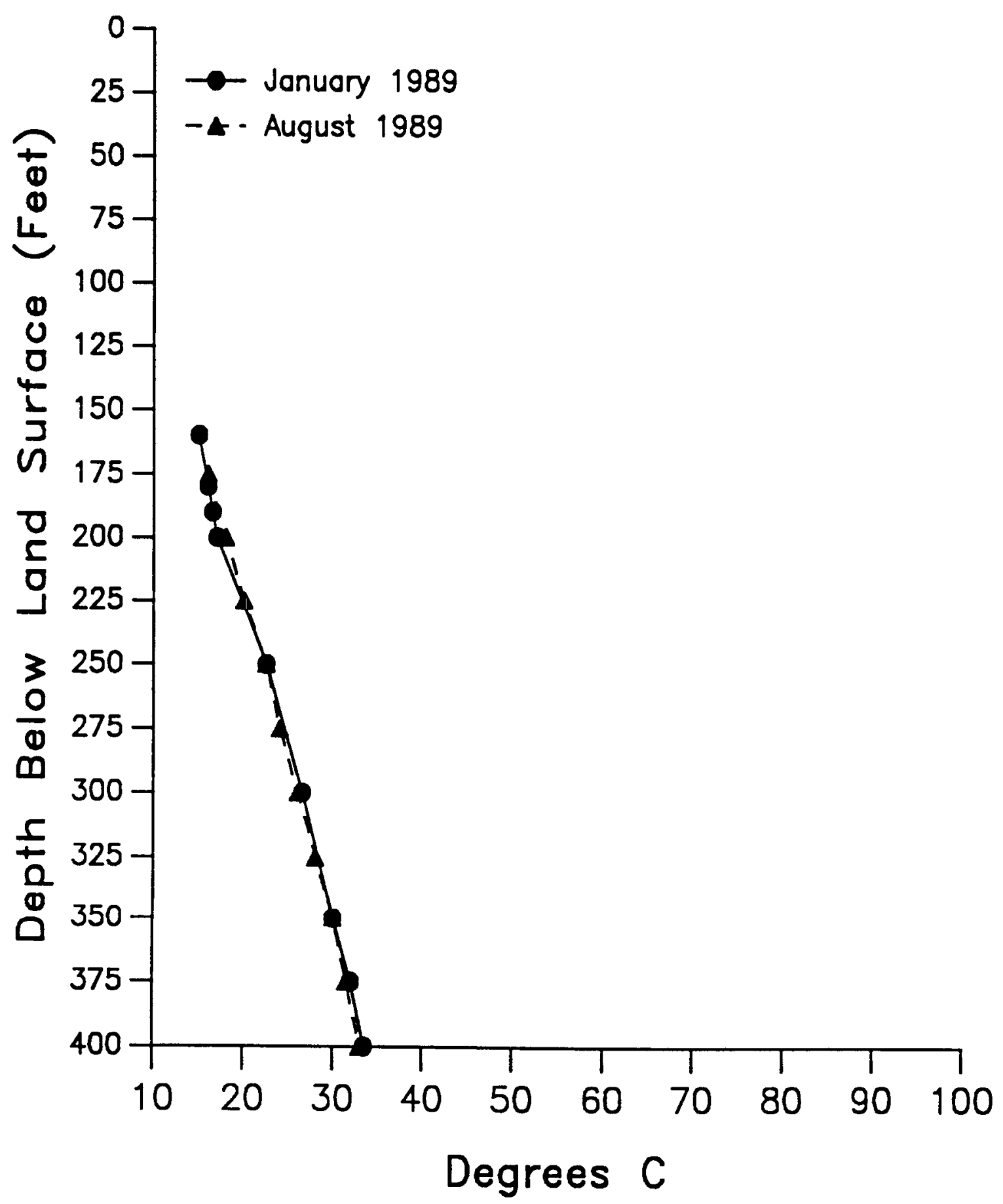




\section{APPENDIX III}

Static Water Levels With Time for All Wells in the Study Group 
WELL 1 STATIC WATER LEVEL

1/89 to 1/90, Downhole Heat Exchanger, Pumped

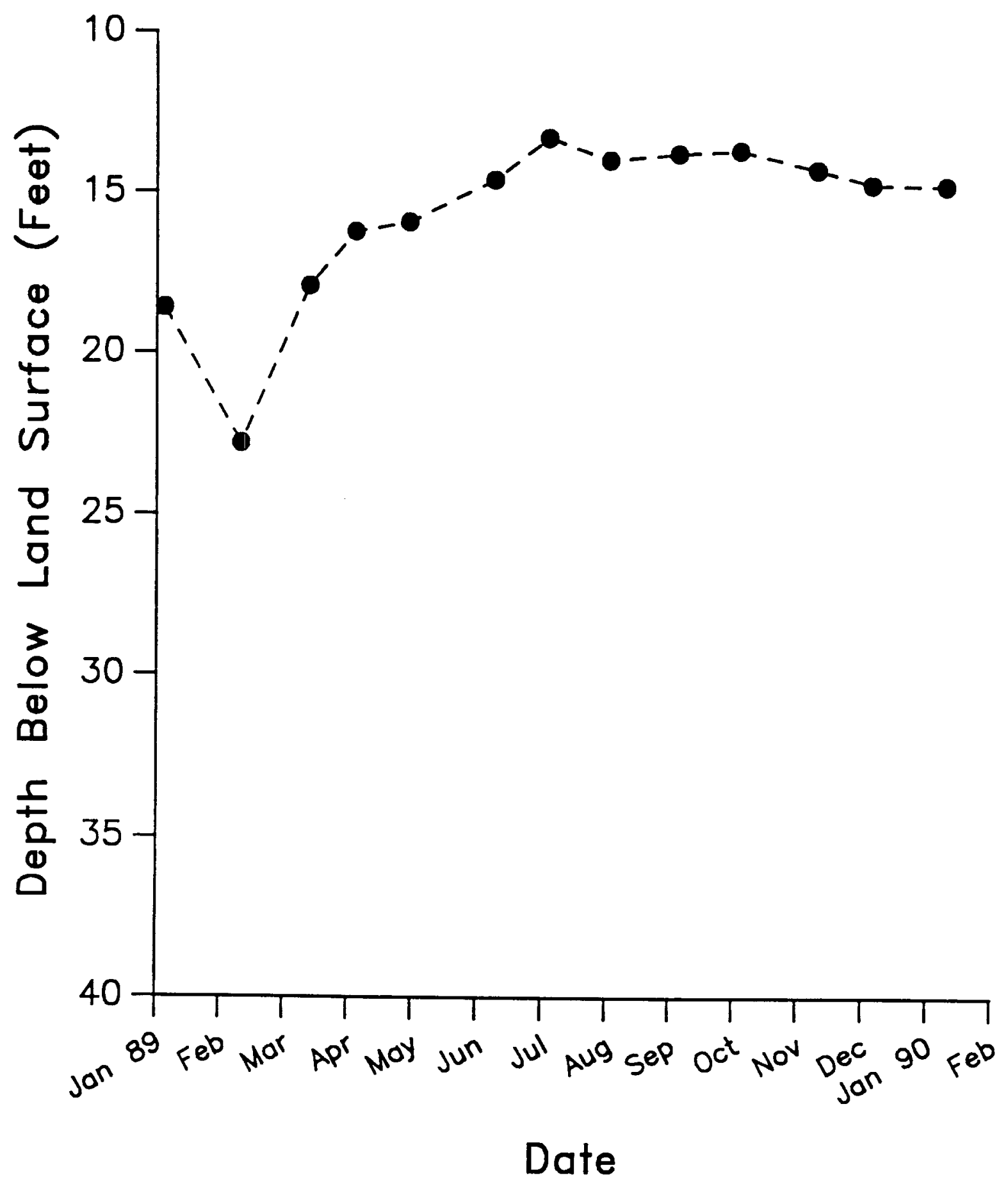




\section{WELL 2 STATIC WATER LEVEL}

$1 / 89$ to $1 / 90$, Downhole Heat Exchanger, Pumped

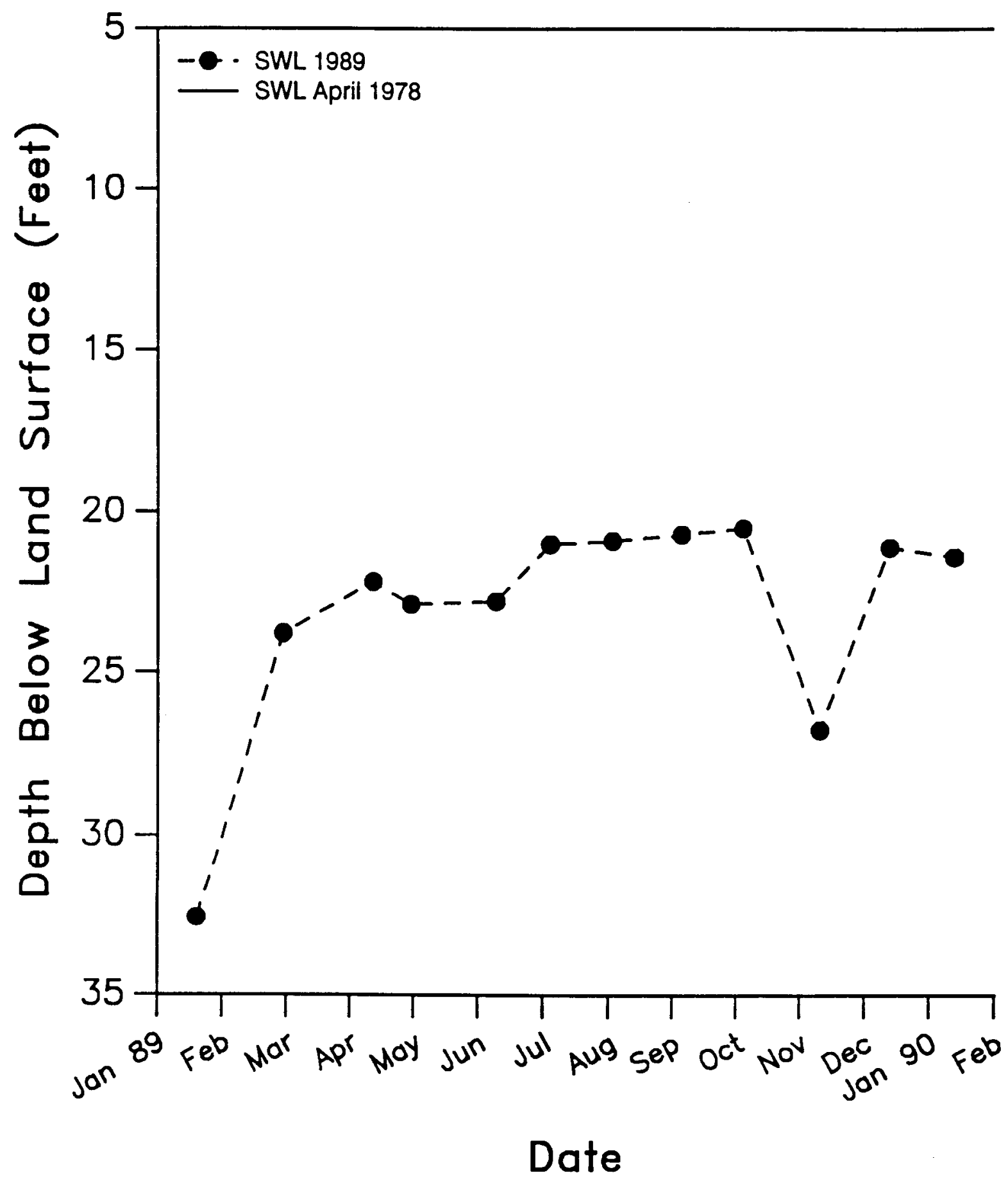


WELL 3 STATIC WATER LEVEL

1/89 to $1 / 90$, Downhole Heat Exchanger, Pumped

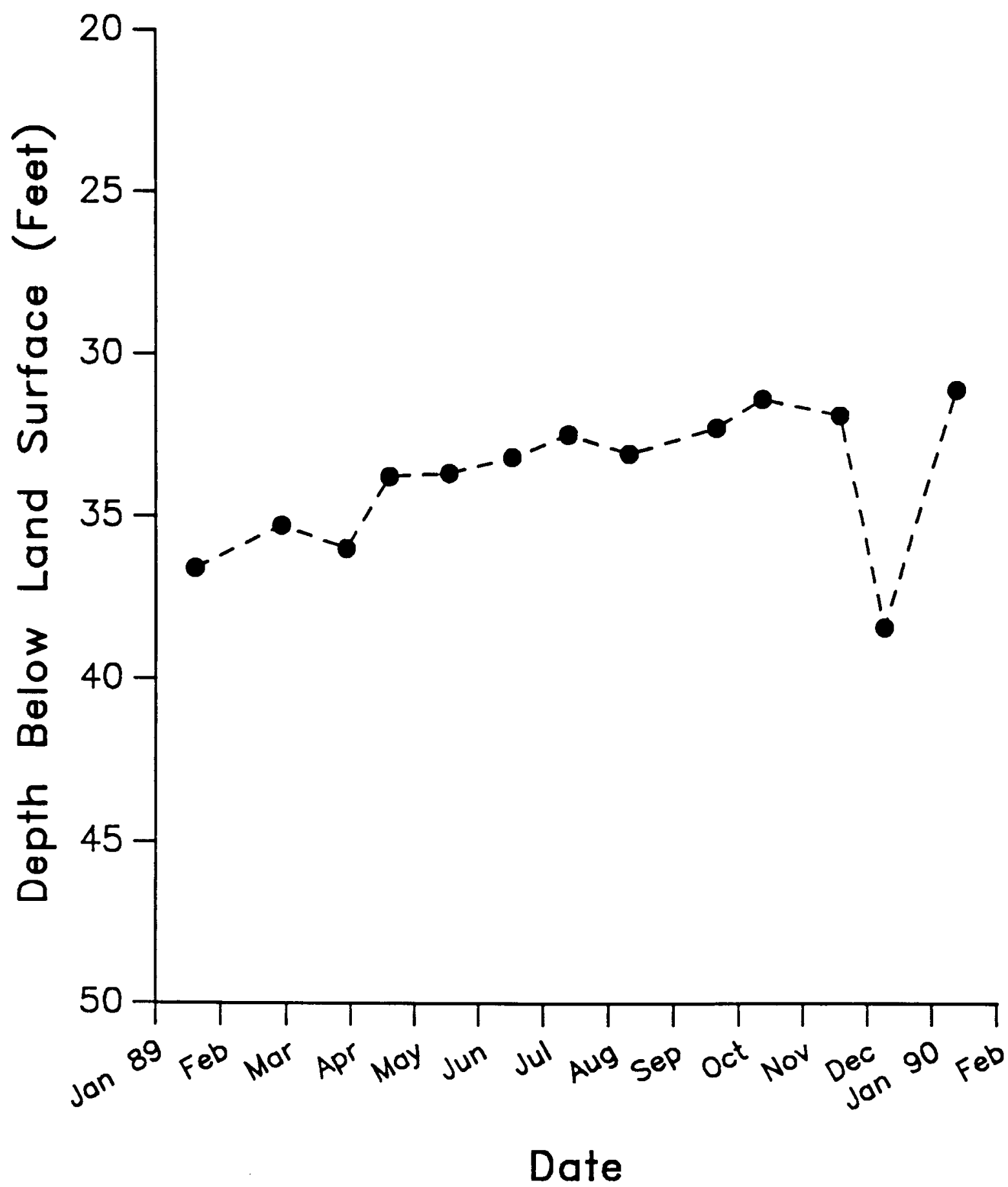




\section{WELL 4 STATIC WATER LEVEL}

1/89 to $1 / 90$, Downhole Heat Exchanger, Pumped

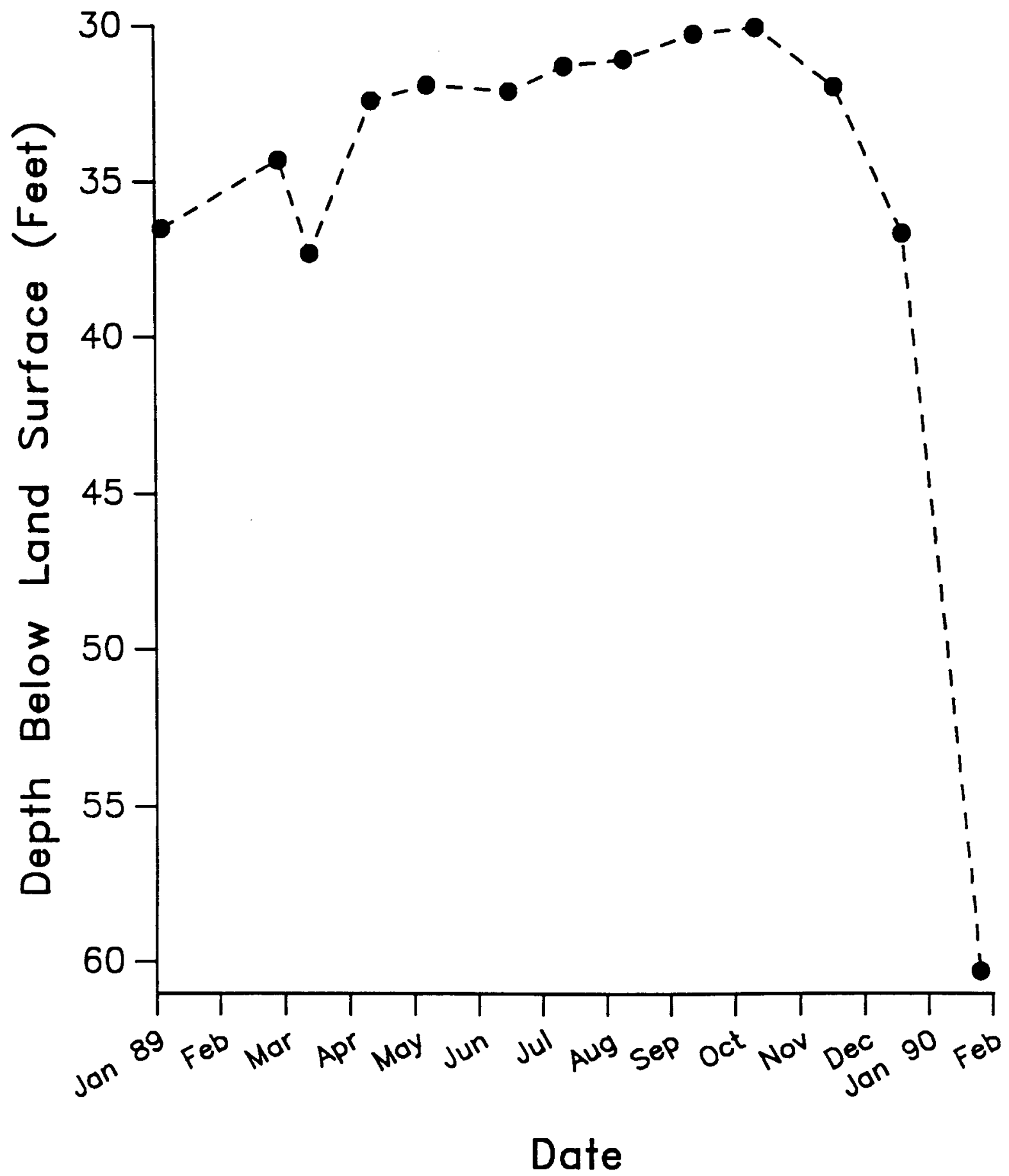




\section{WELL 5 STATIC WATER LEVEL \\ 1/89 to 1/90, Downhole Heat Exchanger, Pumped}

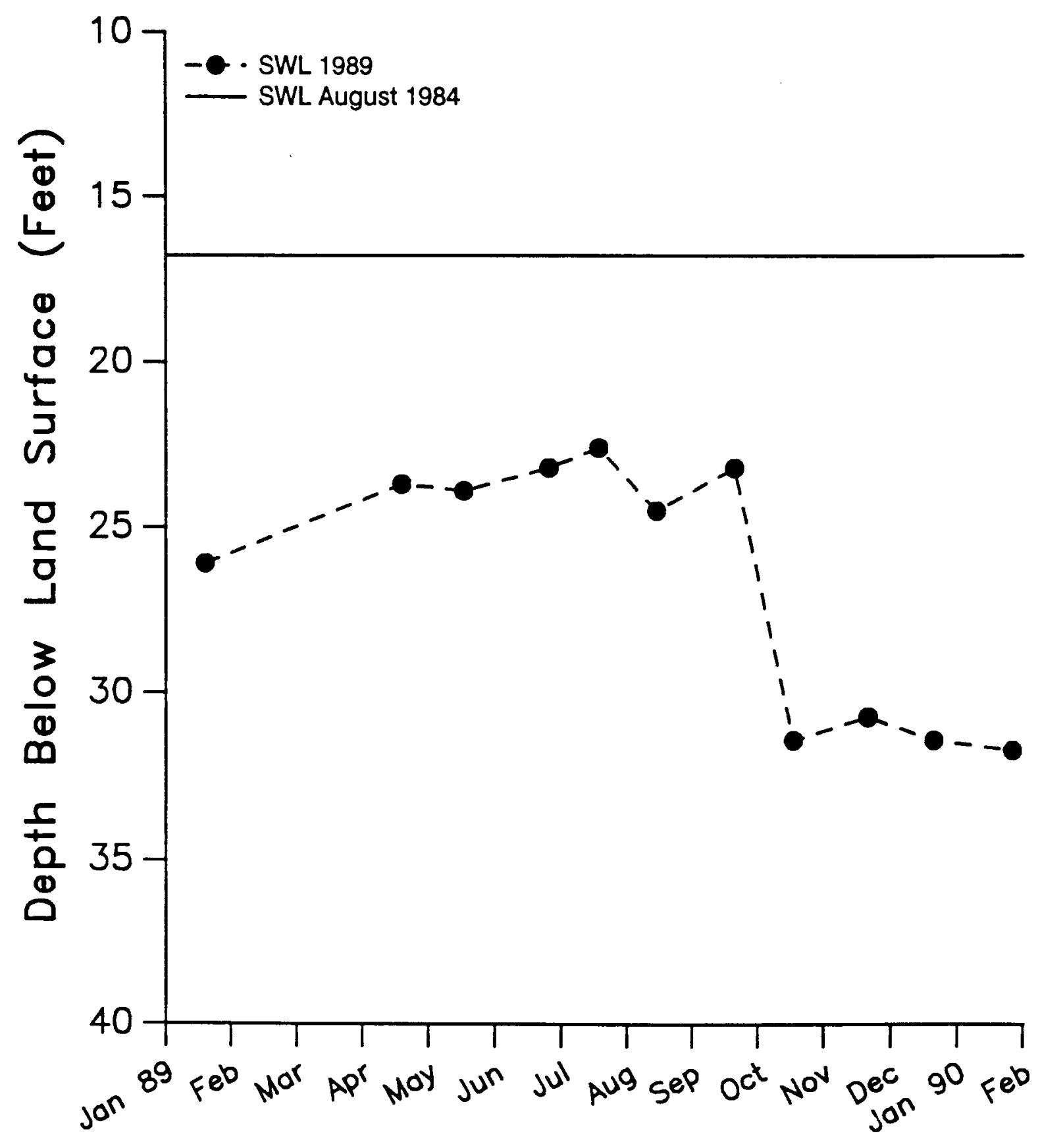

Date 
WELL 6 STATIC WATER LEVEL

1/89 to $1 / 90$, Downhole Heat Exchanger, Pumped

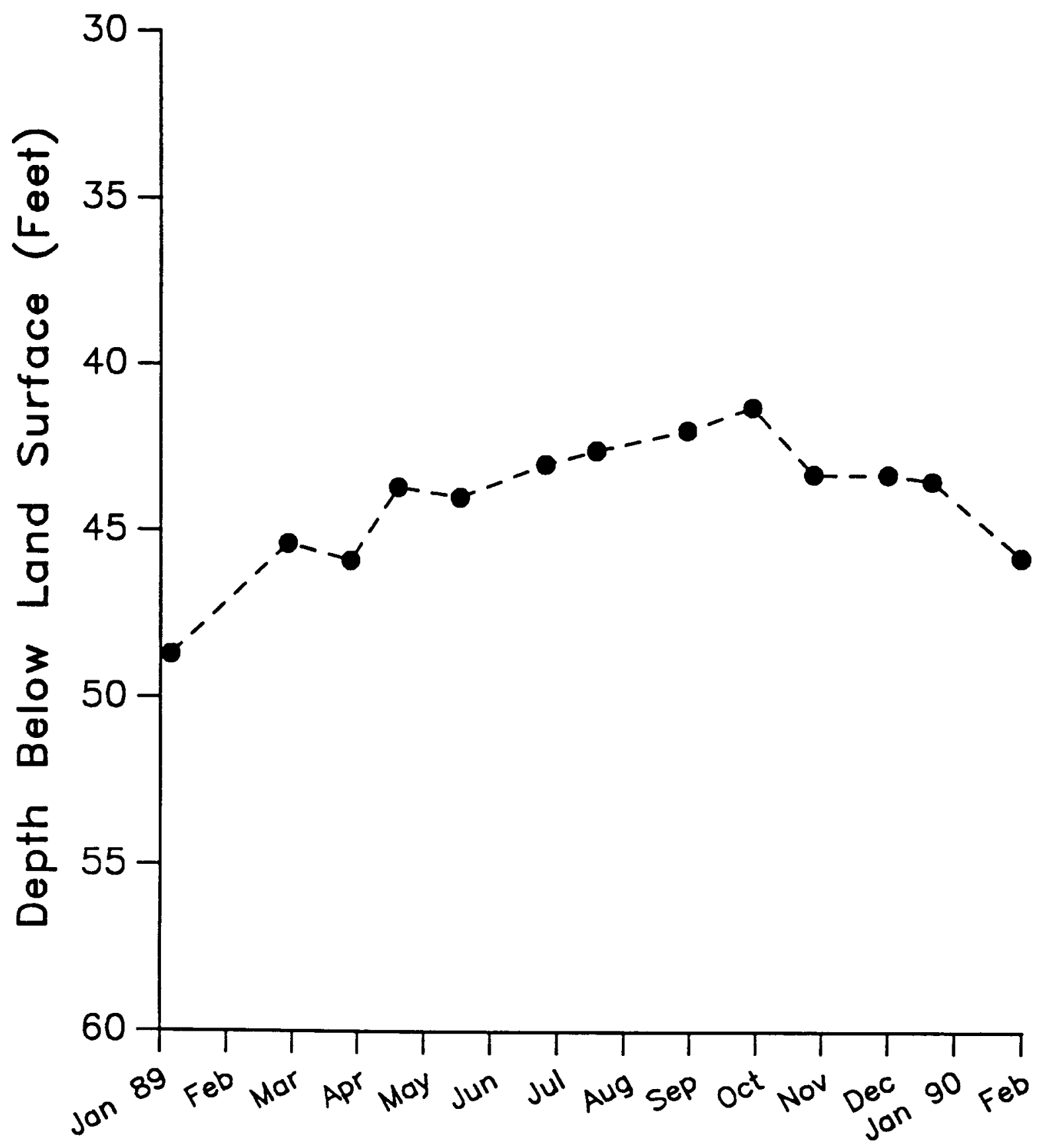

Date 


\section{WELL 7 STATIC WATER LEVEL \\ 1/89 to $1 / 90$, Downhole Heat Exchanger, Pumped}

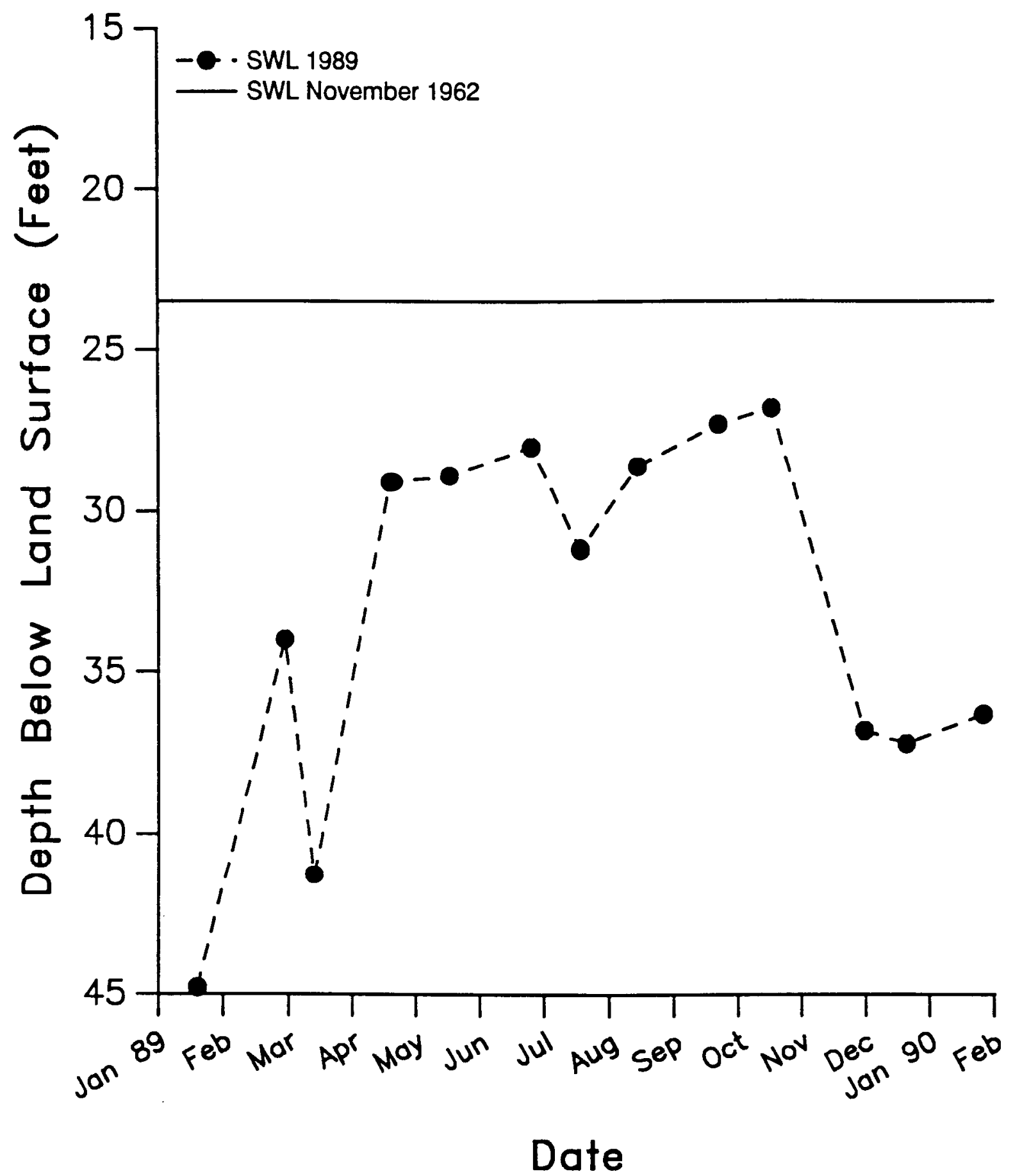




\section{WELL 8 STATIC WATER LEVEL \\ 1/89 to 1/90, Downhole Heat Exchanger, Pumped}

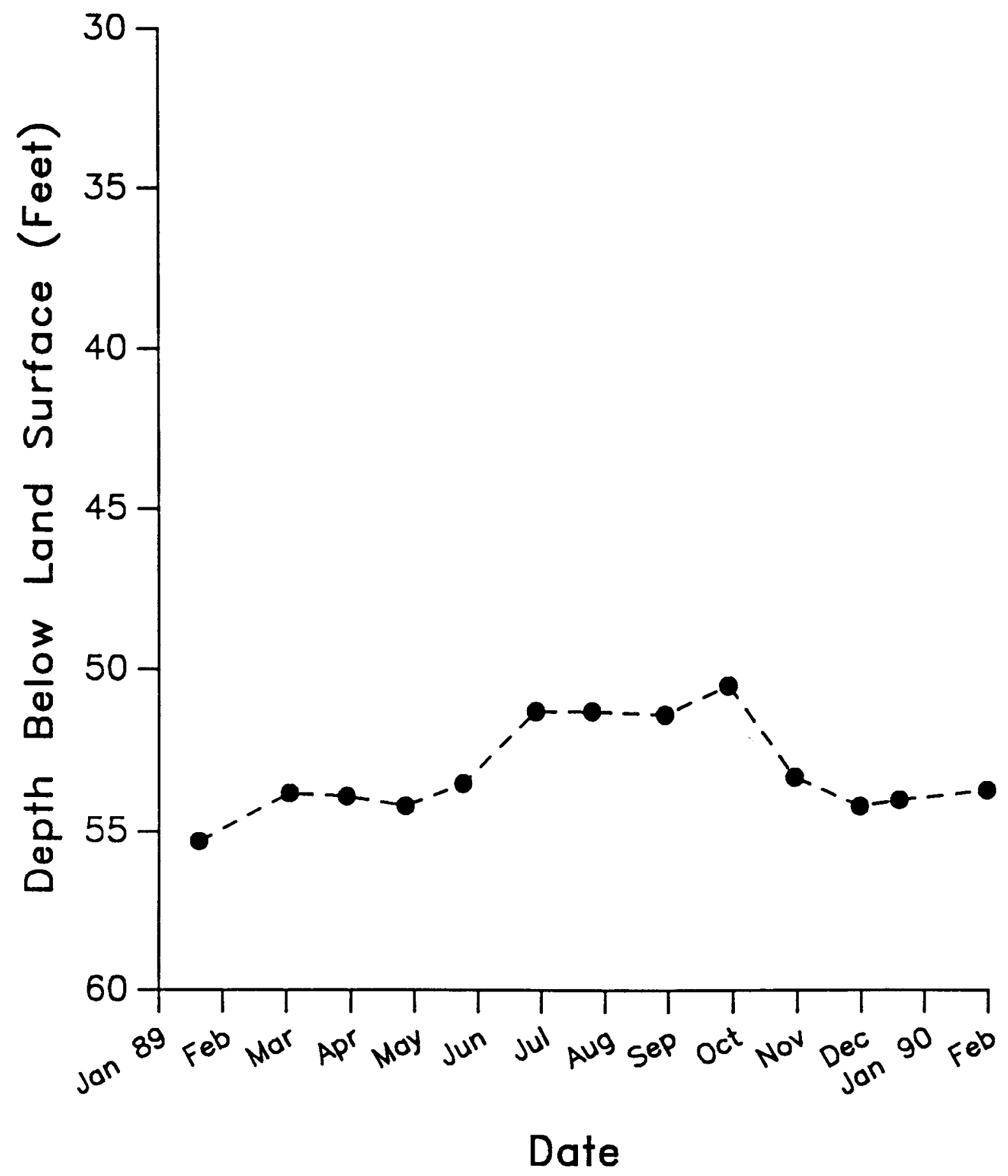


WELL 9 STATIC WATER LEVEL

1/89 to 1/90, Downhole Heat Exchanger, Pumped

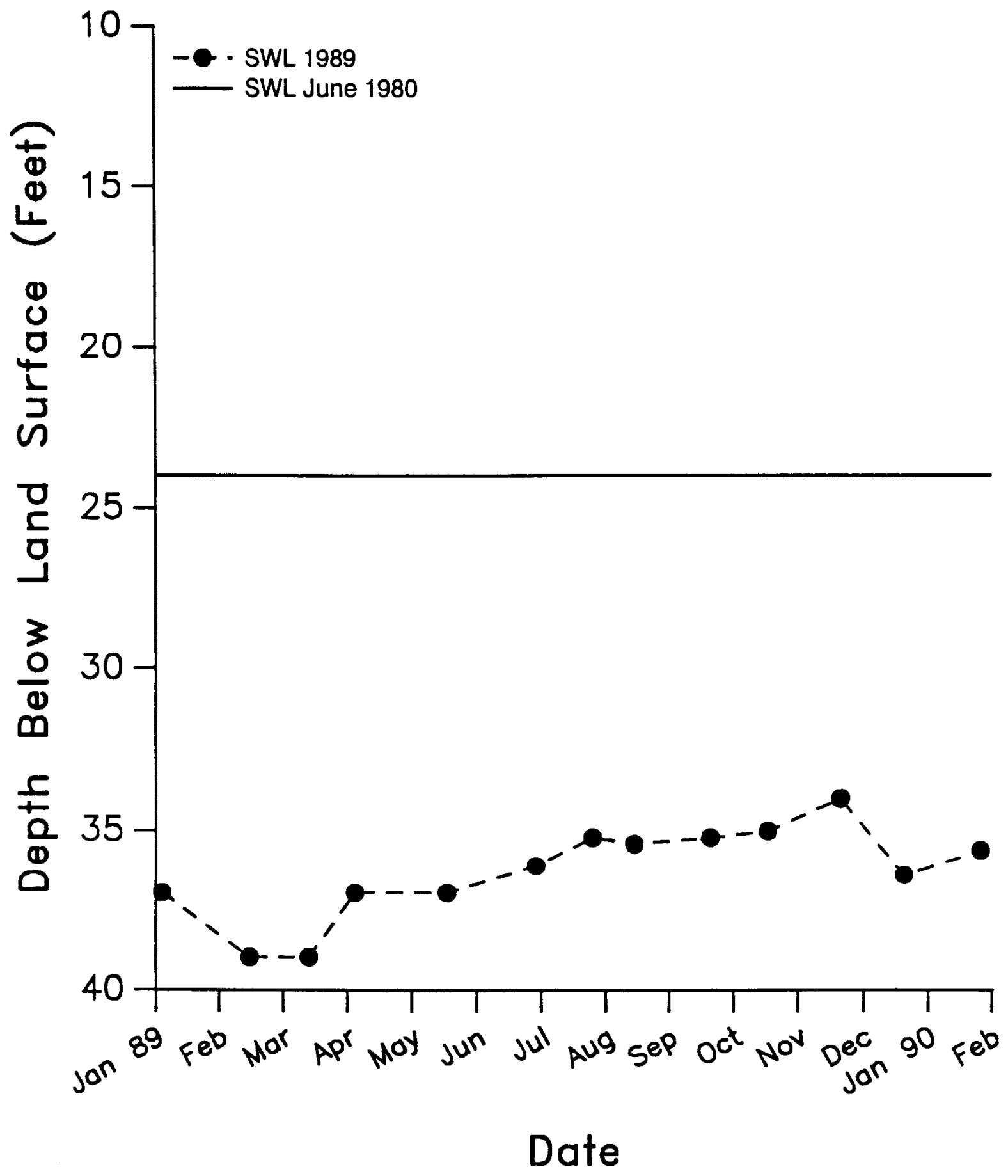


WELL 10 STATIC WATER LEVEL

1/89 to 1/90, Downhole Heat Exchanger, Pumped

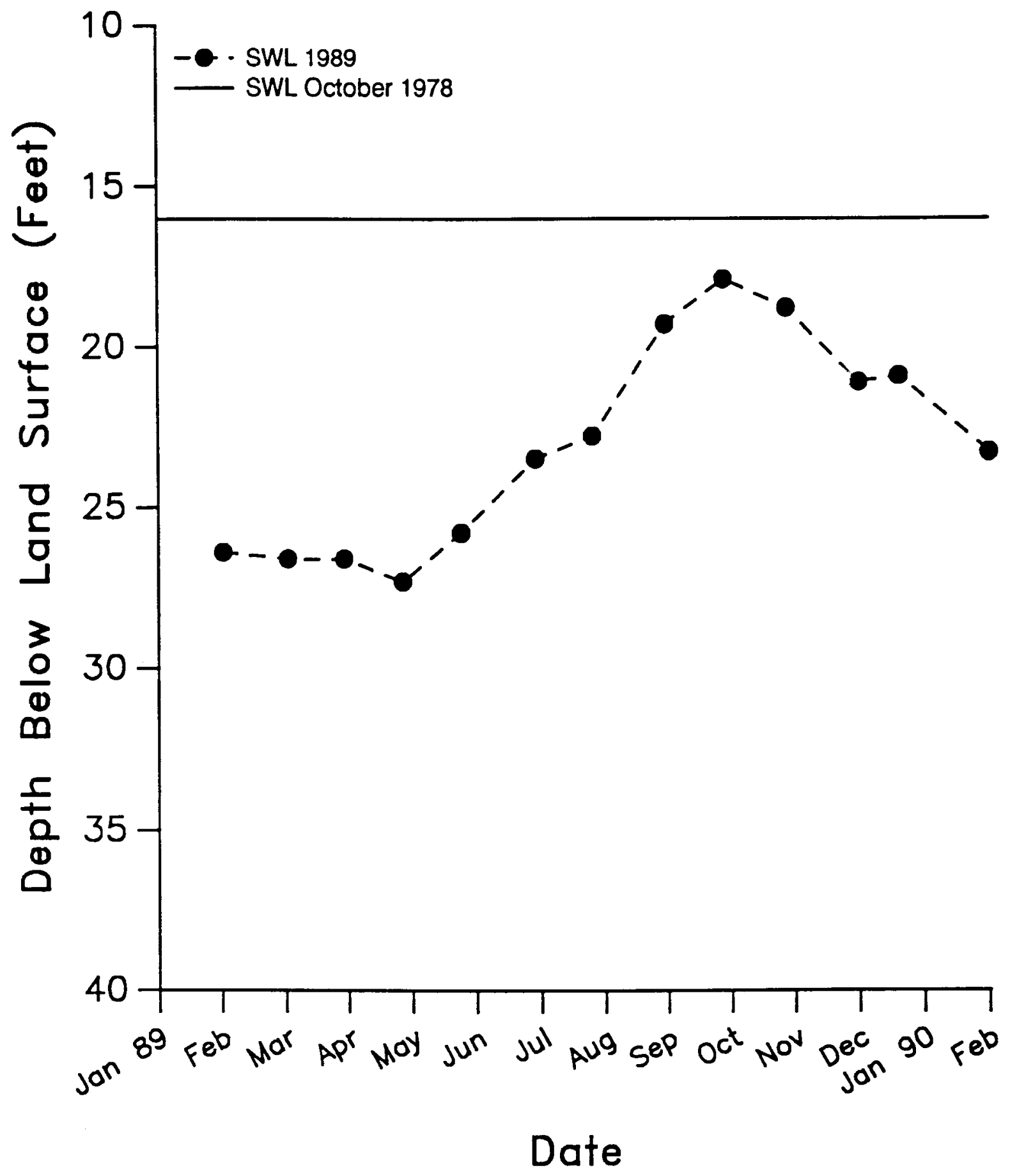




\section{WELL 11 STATIC WATER LEVEL \\ $3 / 89$ to $1 / 90$, Downhole Heat Exchanger, No Pump}

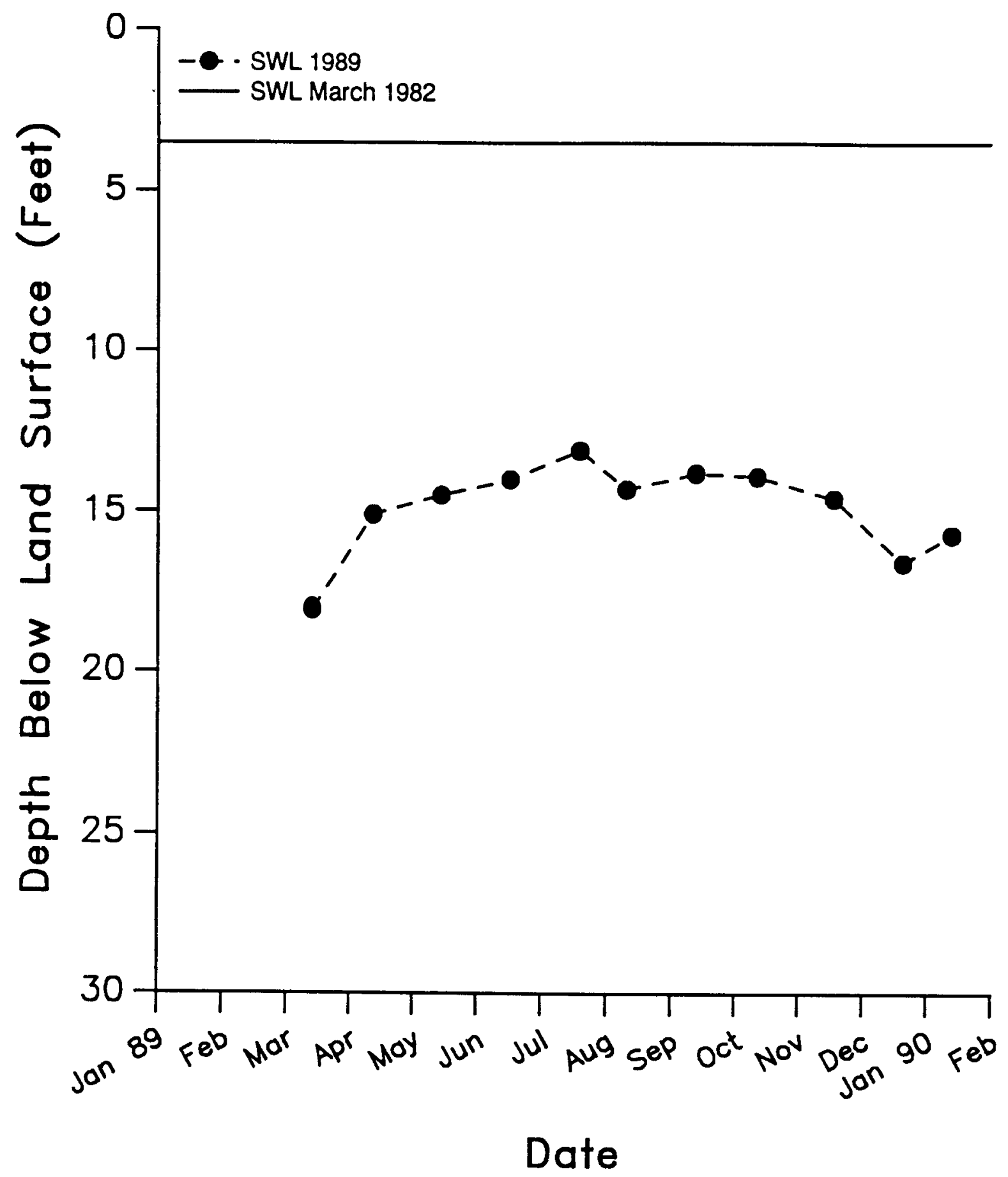


WELL 12 STATIC WATER LEVEL

1/89 to 1/90, Downhole Heat Exchanger, No Pump

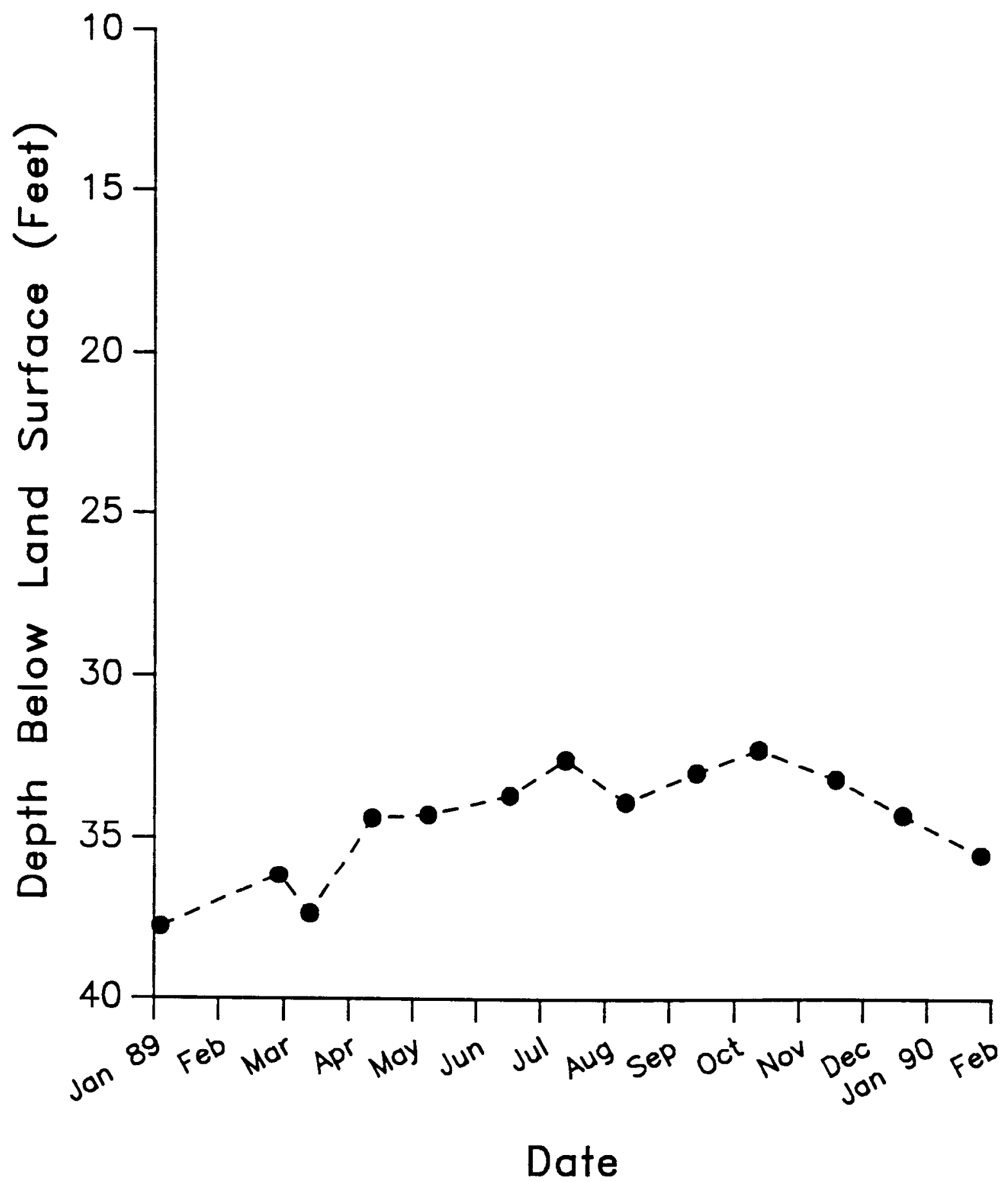




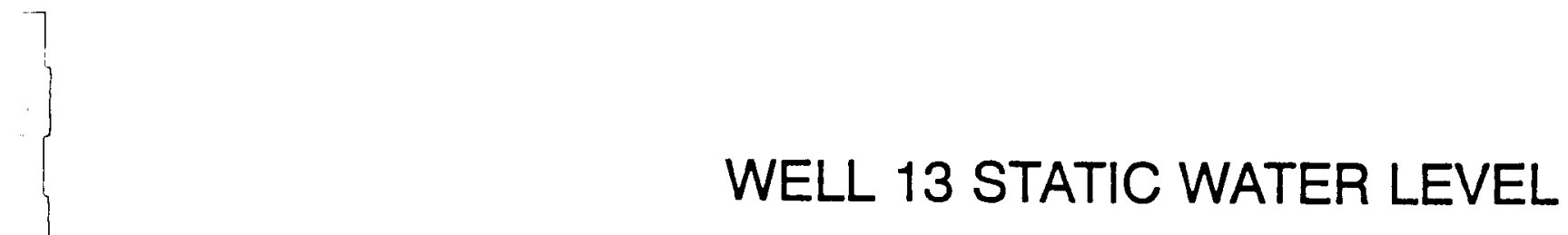

$1 / 89$ to $1 / 90$, Downhole Heat Exchanger, No Pump

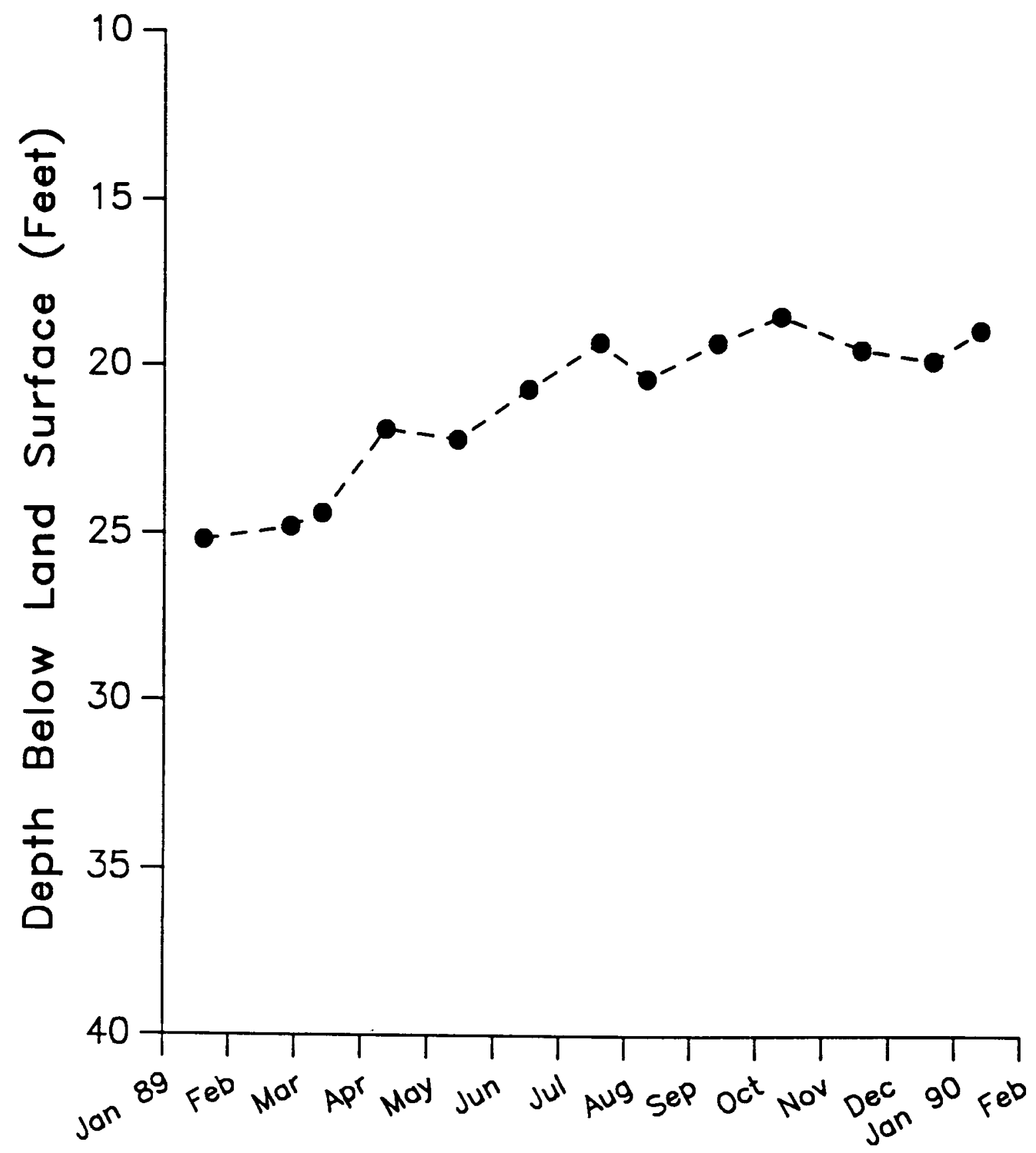

Date 
1/89 to 1/90, Downhole Heat Exchanger, No Pump

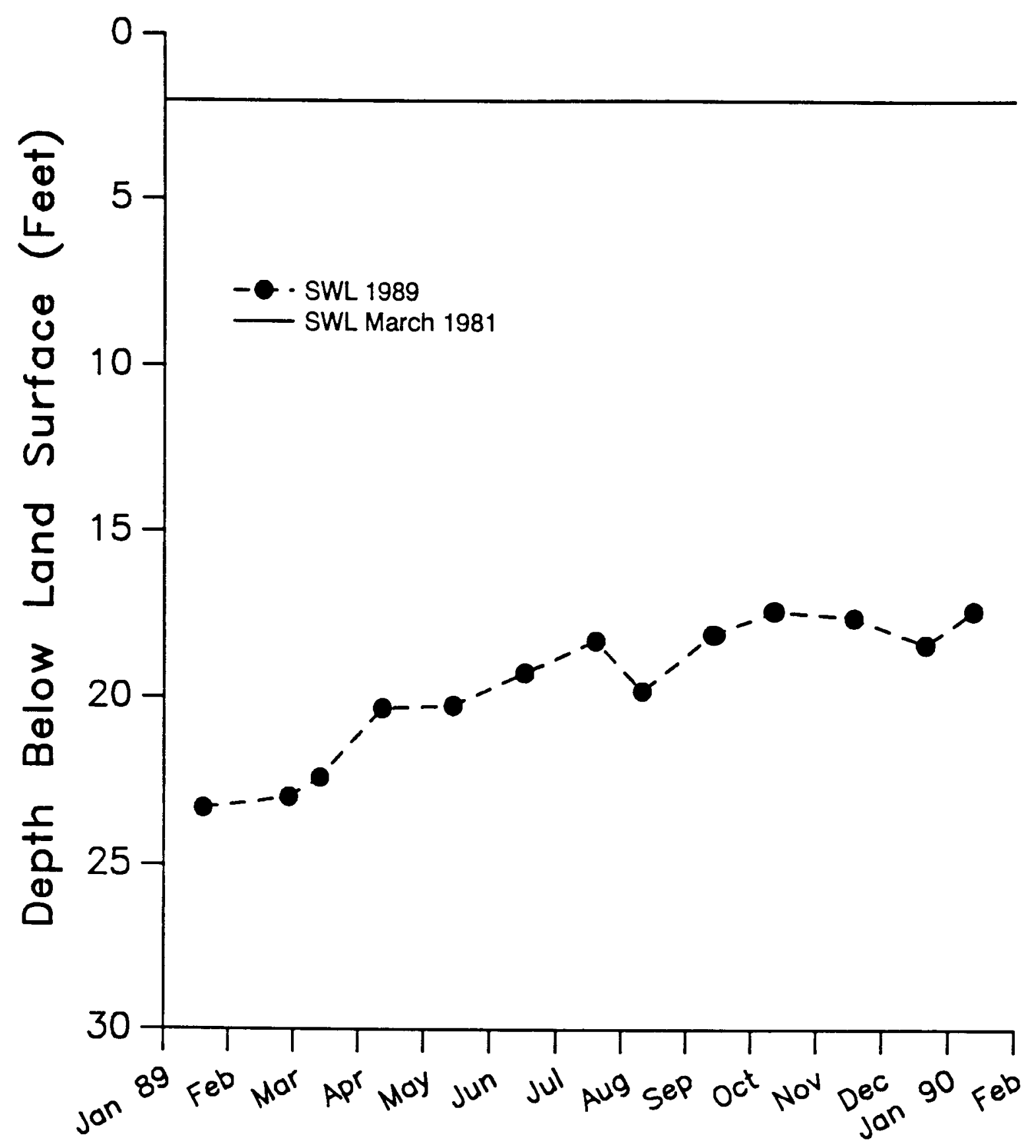

Date 
WELL 15 STATIC WATER LEVEL

1/89 to $1 / 90$, Downhole Heat Exchanger, No Pump

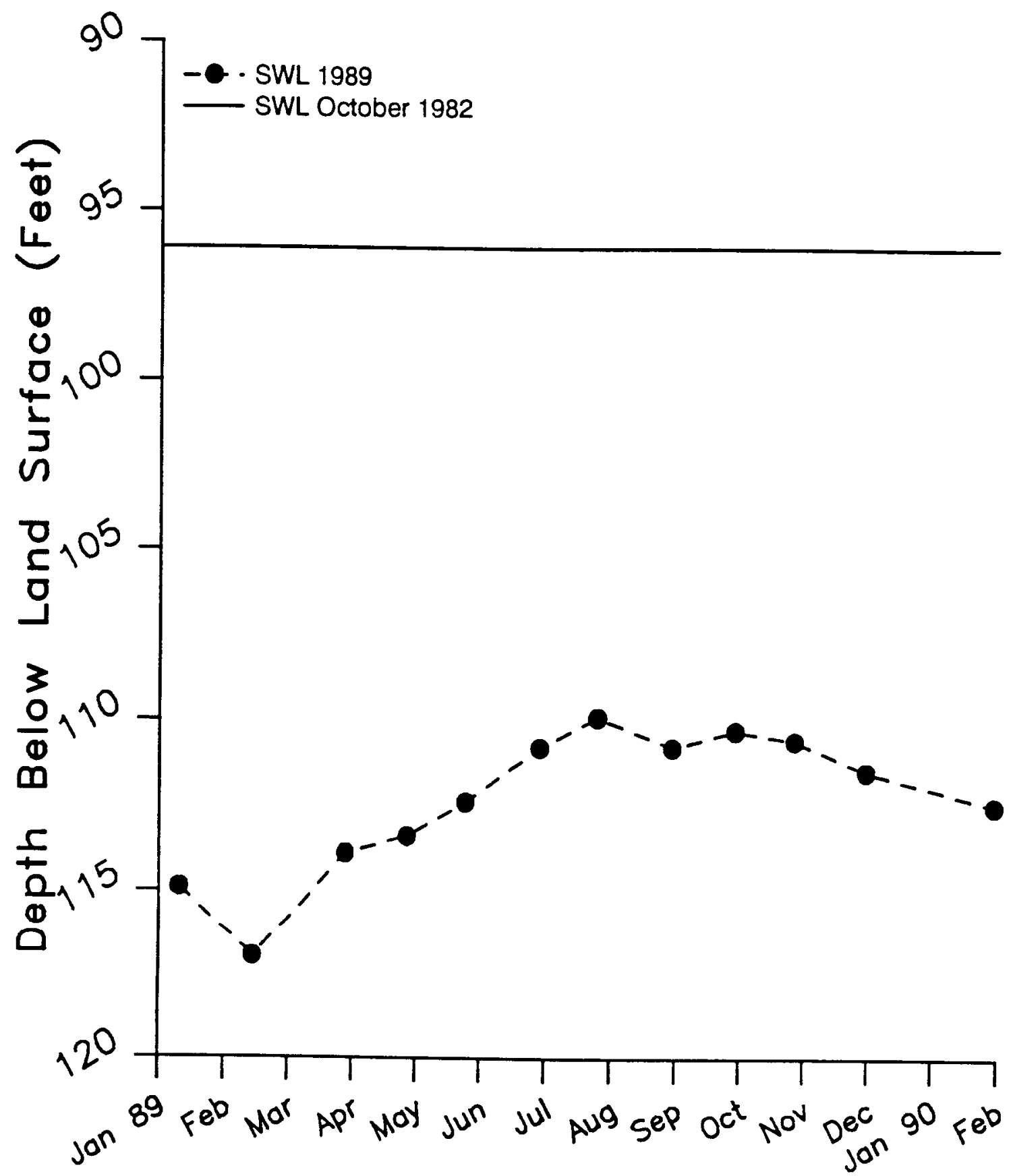

Date 


\section{WELL 16 STATIC WATER LEVEL \\ 1/89 to $1 / 90$, Extractive Well}

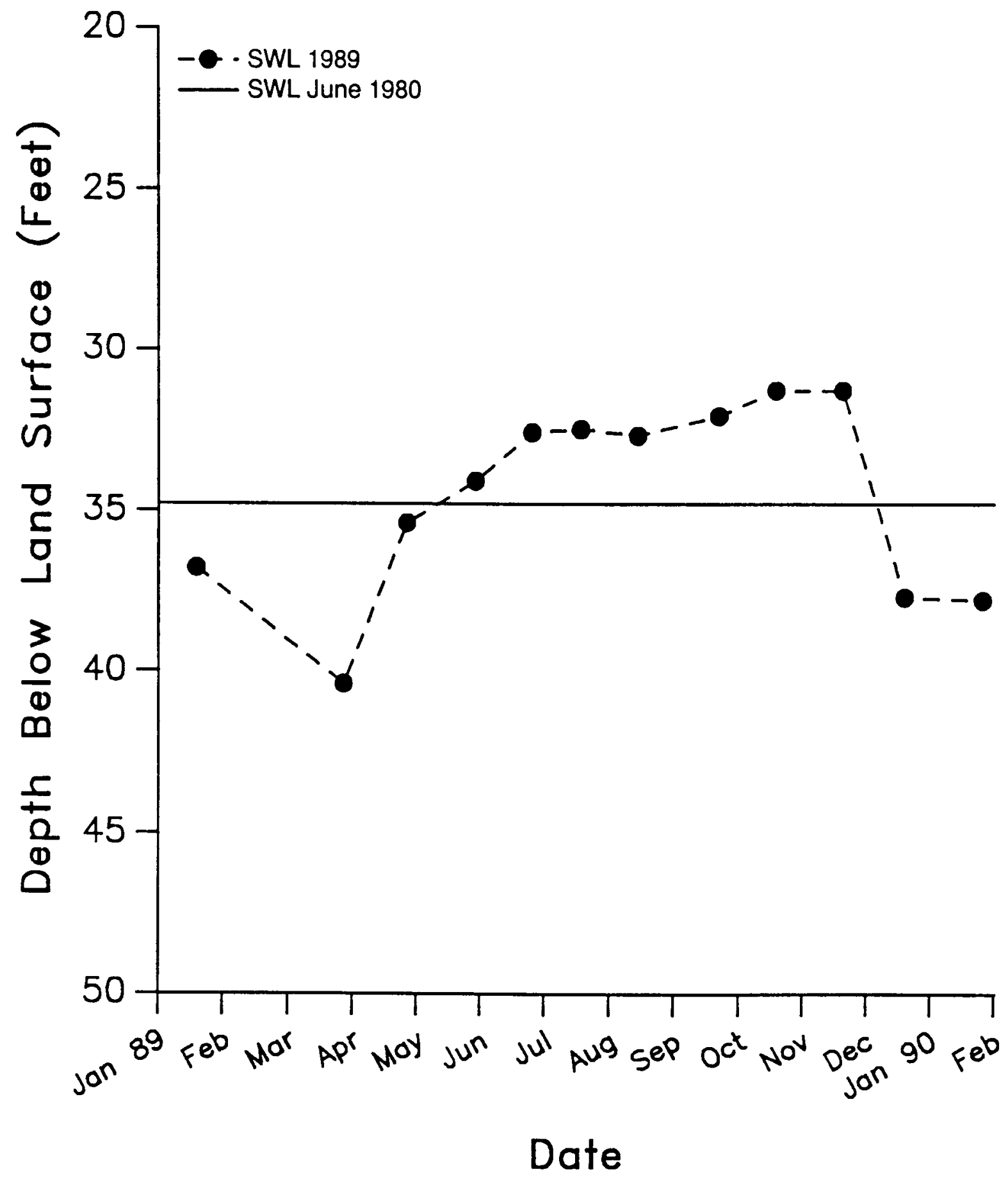




\section{WELL 17 STATIC WATER LEVEL}

\section{$1 / 89$ to $1 / 90$, Extractive Well}

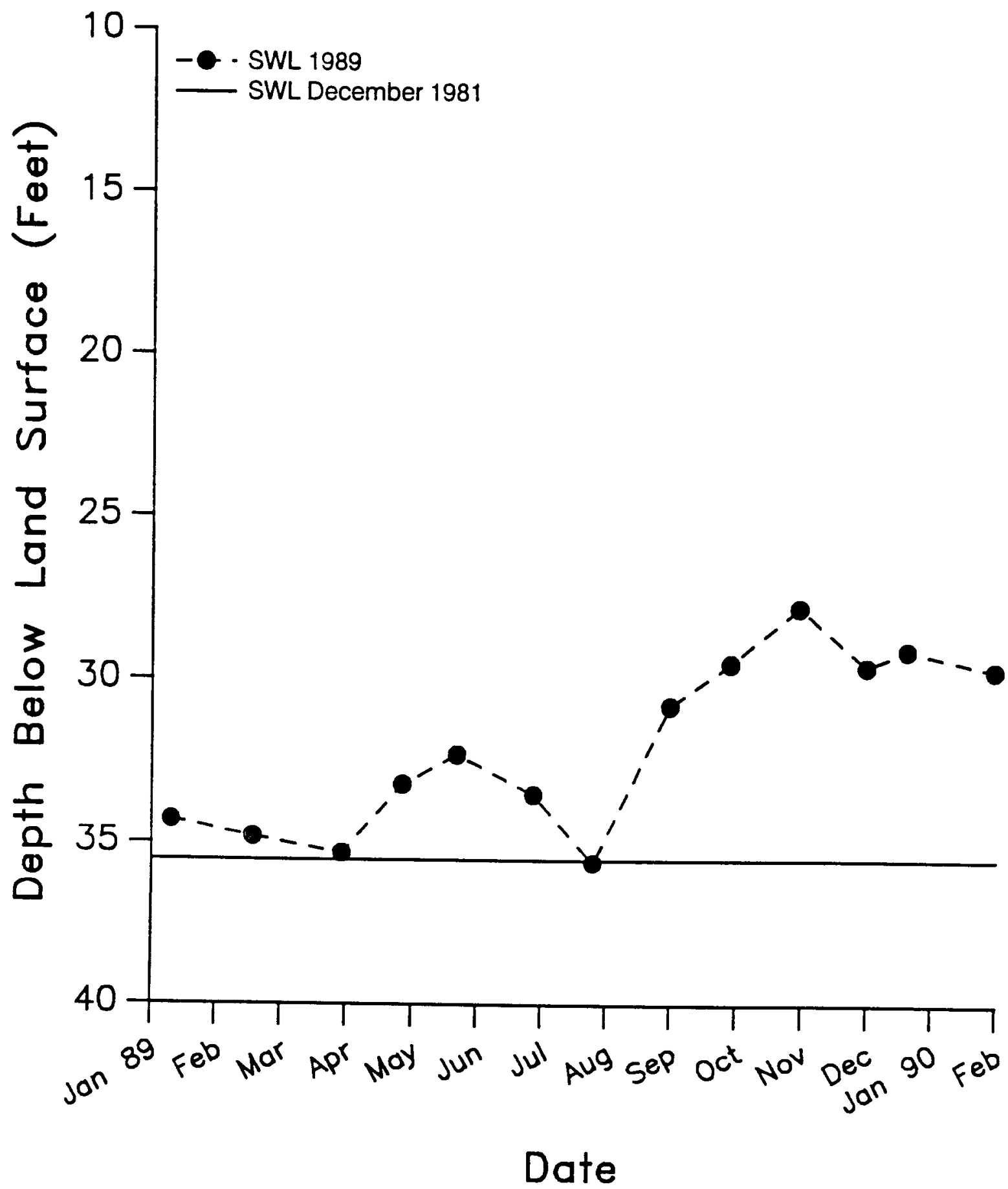




\section{WELL 18 STATIC WATER LEVEL $1 / 89$ to $1 / 90$, Extractive Well}

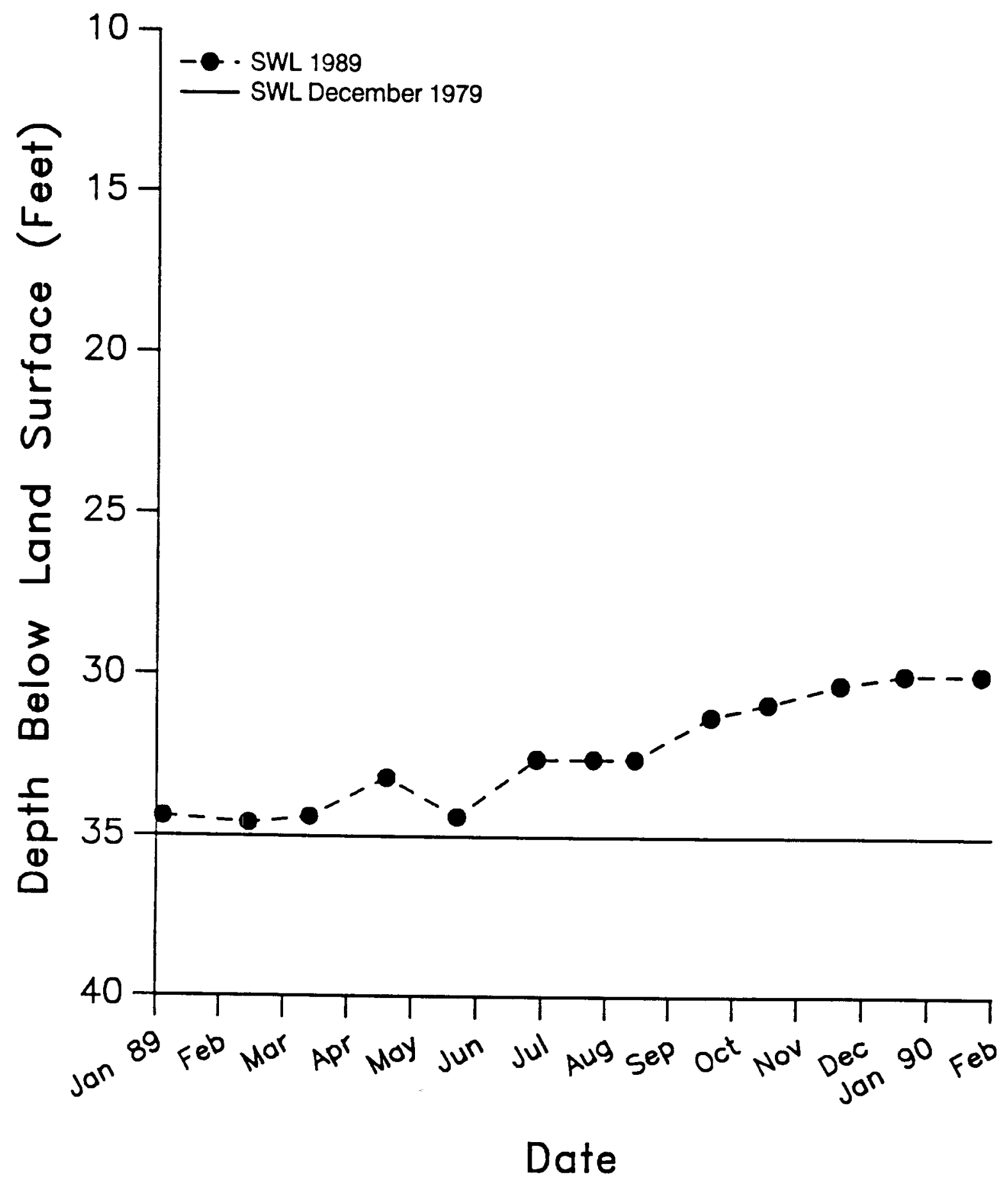




\section{WELL 19 STATIC WATER LEVEL \\ $1 / 89$ to $1 / 90$, Unused Domestic Well}

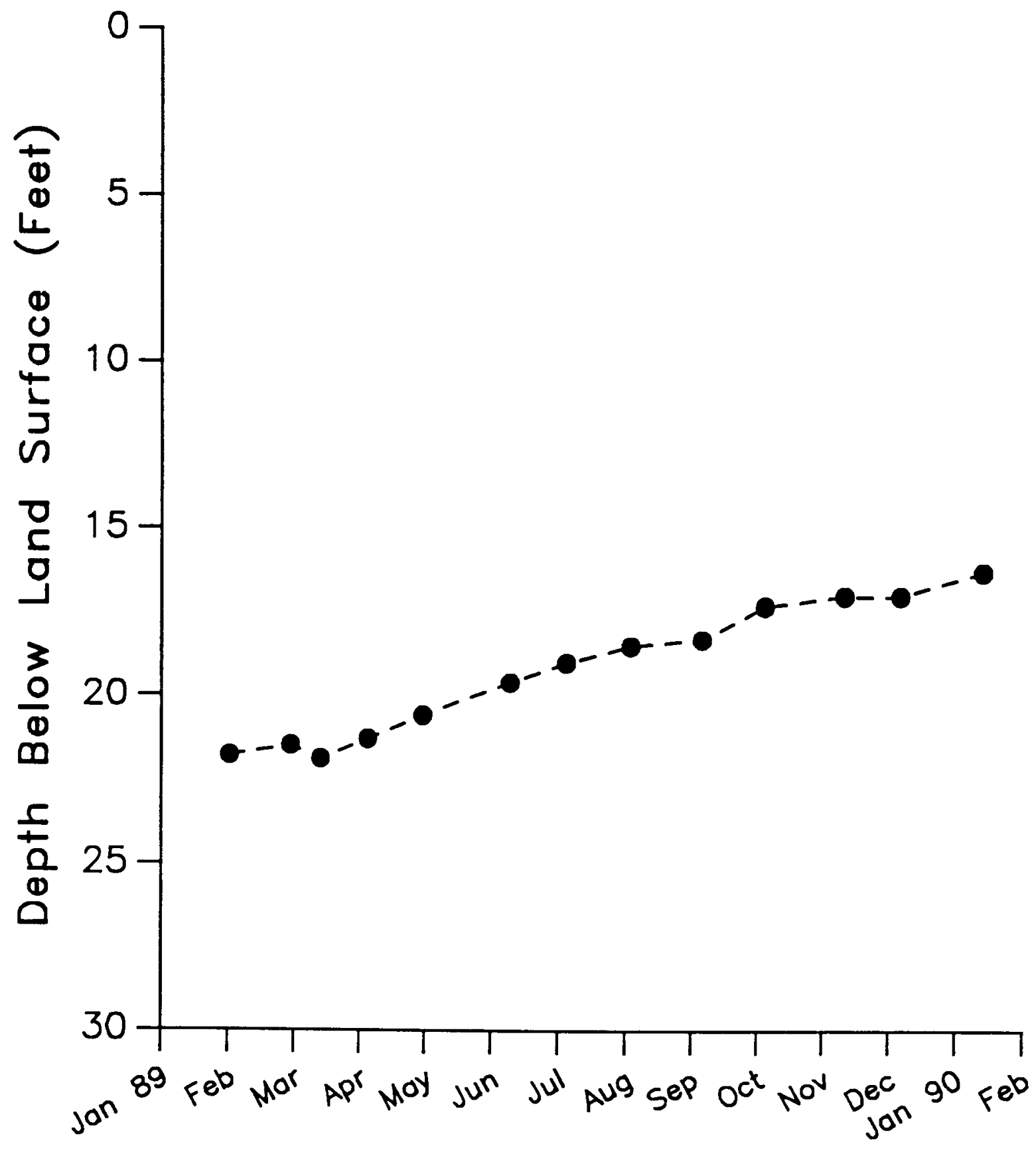

Date 


\section{WELL 20 STATIC WATER LEVEL \\ $1 / 89$ to $1 / 90$, Unused Domestic Well}

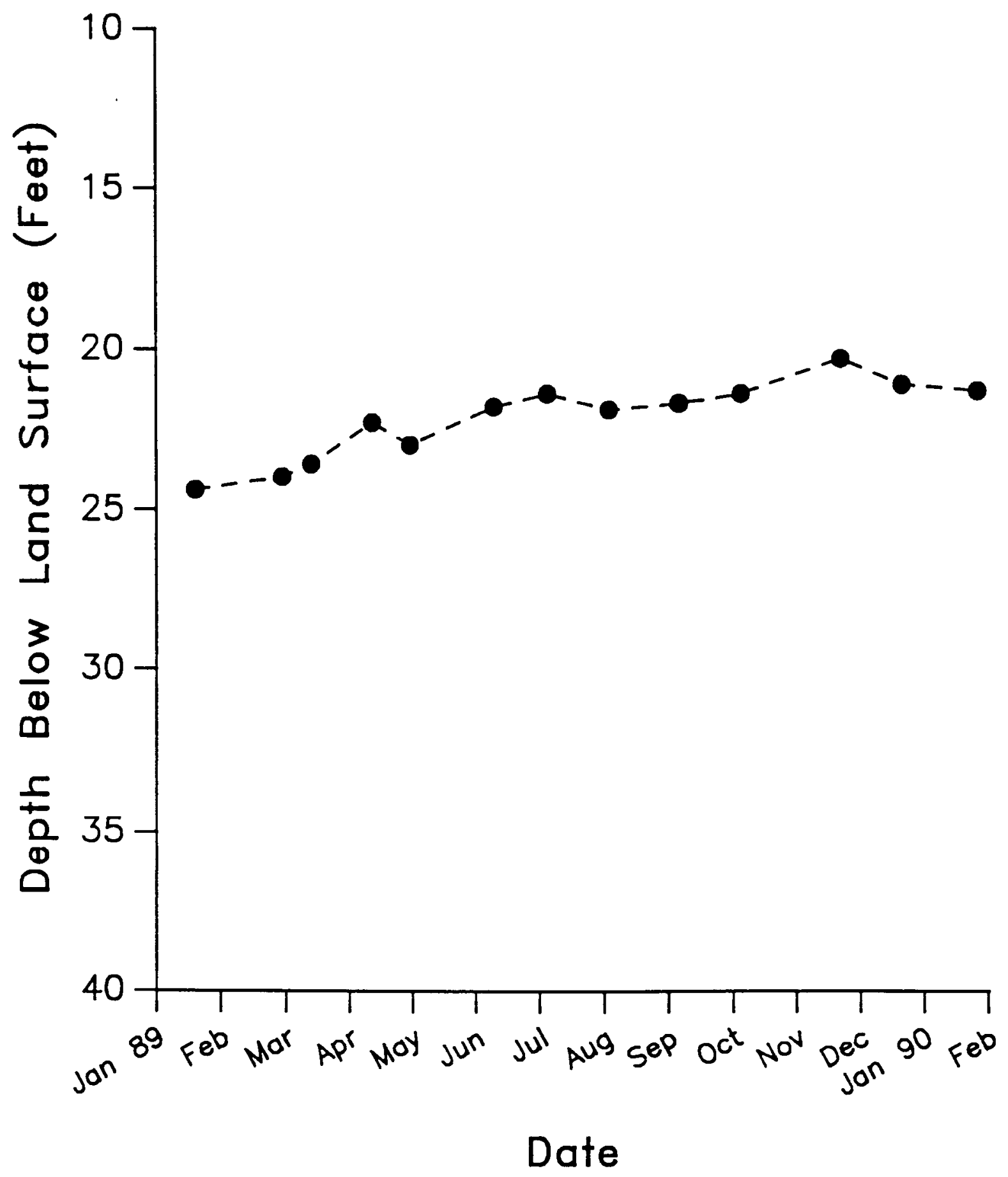




\section{WELL 21 STATIC WATER LEVEL \\ $1 / 89$ to $1 / 90$, Unused Domestic Well}

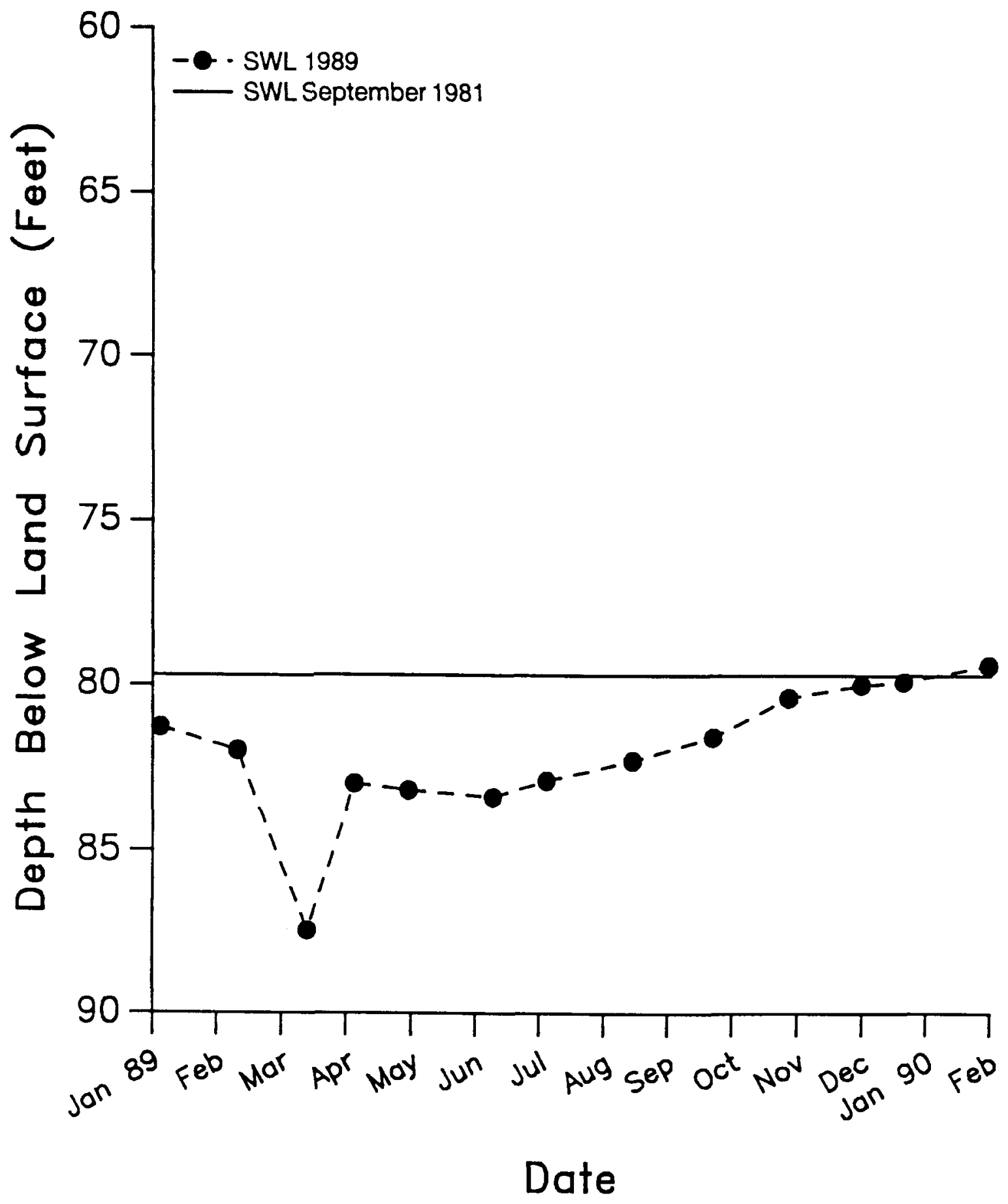




\section{WELL 22 STATIC WATER LEVEL}

$1 / 89$ to $1 / 90$, Unused Domestic Well

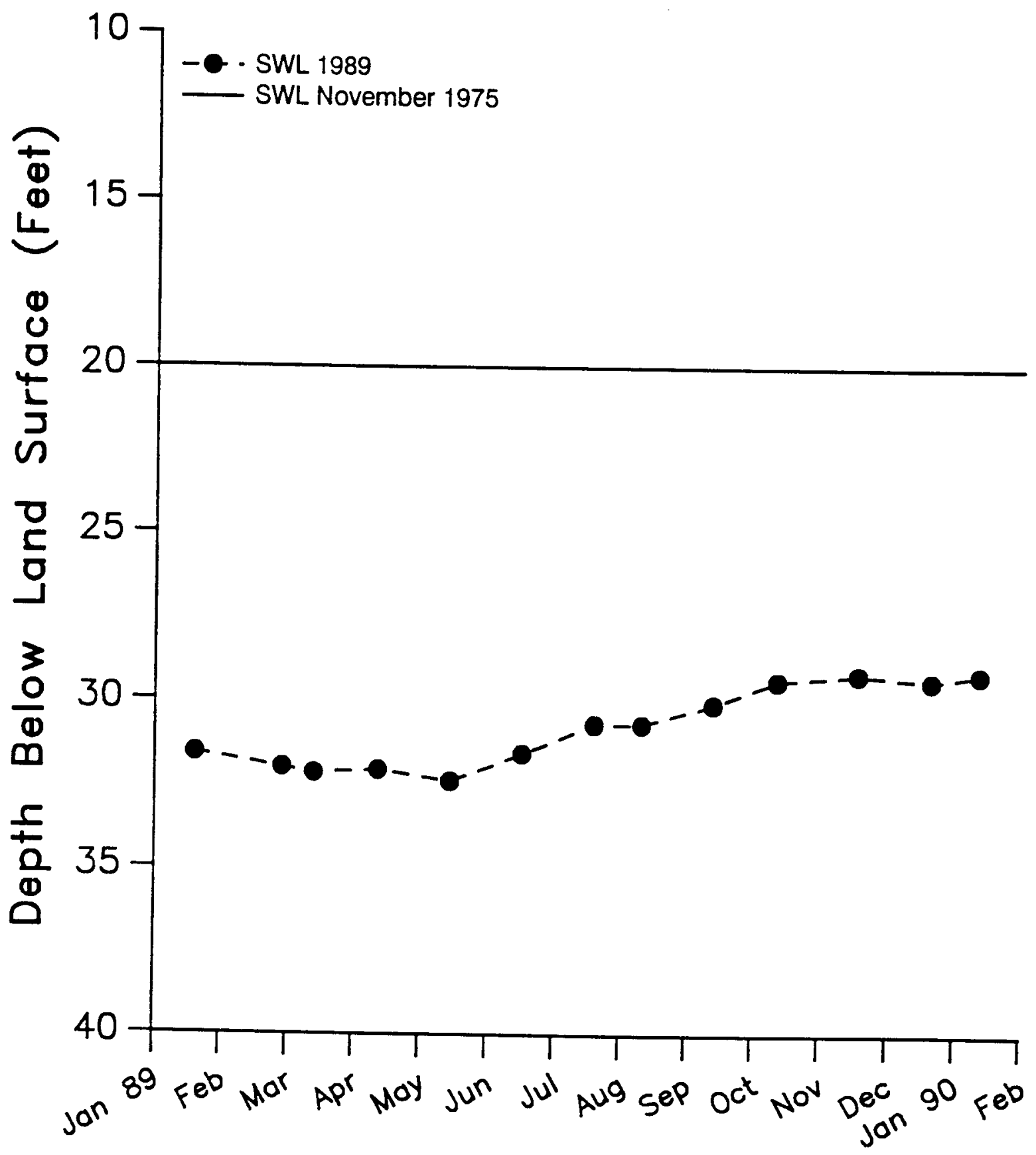

Date 


\section{WELL 23 STATIC WATER LEVEL}

$1 / 89$ to $1 / 90$, Unused Commercial Well

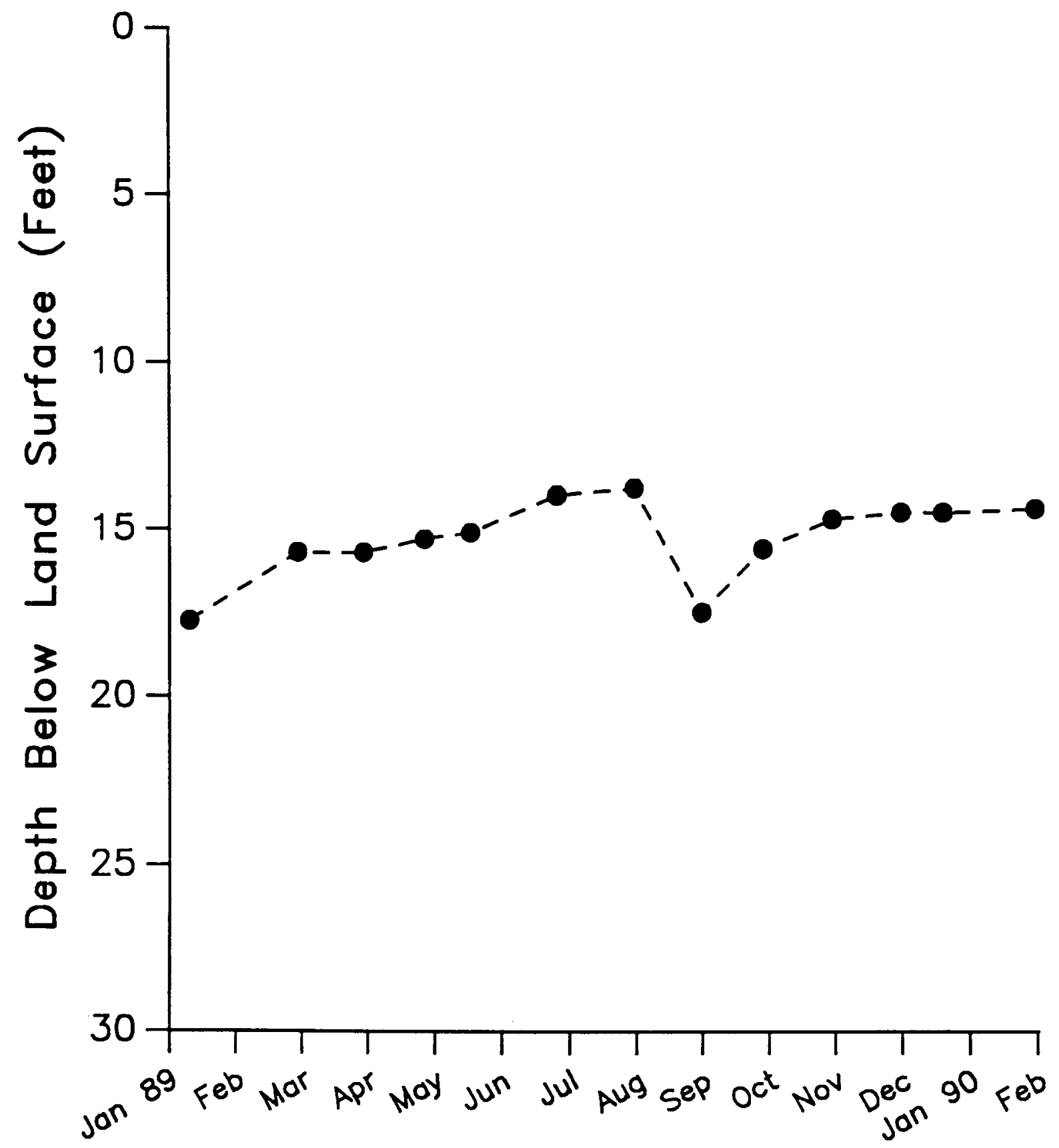

Date 


\section{WELL 24 STATIC WATER LEVEL \\ $1 / 89$ to $1 / 90$, Unused Domestic Well}

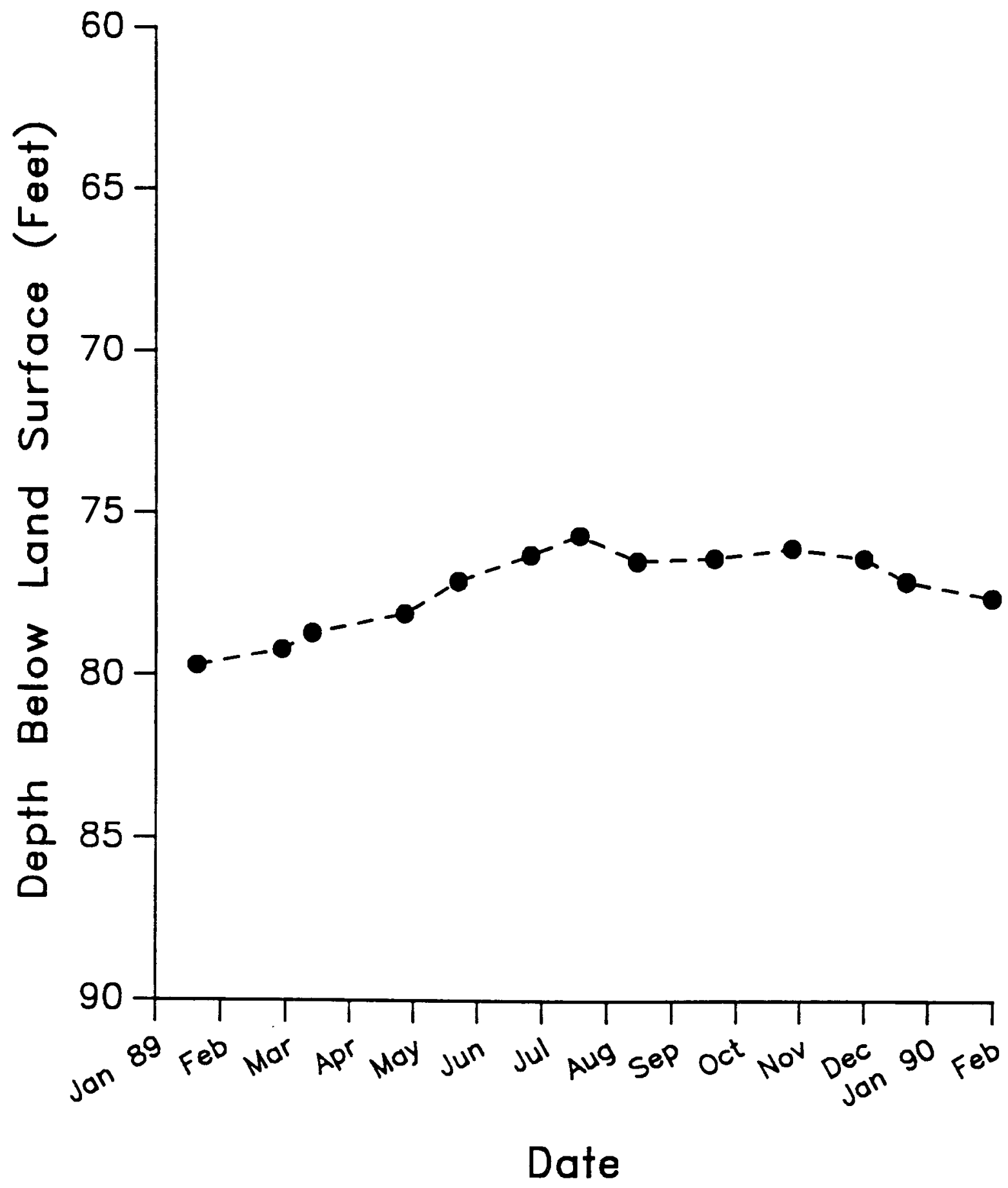




\section{WELL 25 STATIC WATER LEVEL \\ $6 / 83$ to $2 / 90$, Monitoring Well}

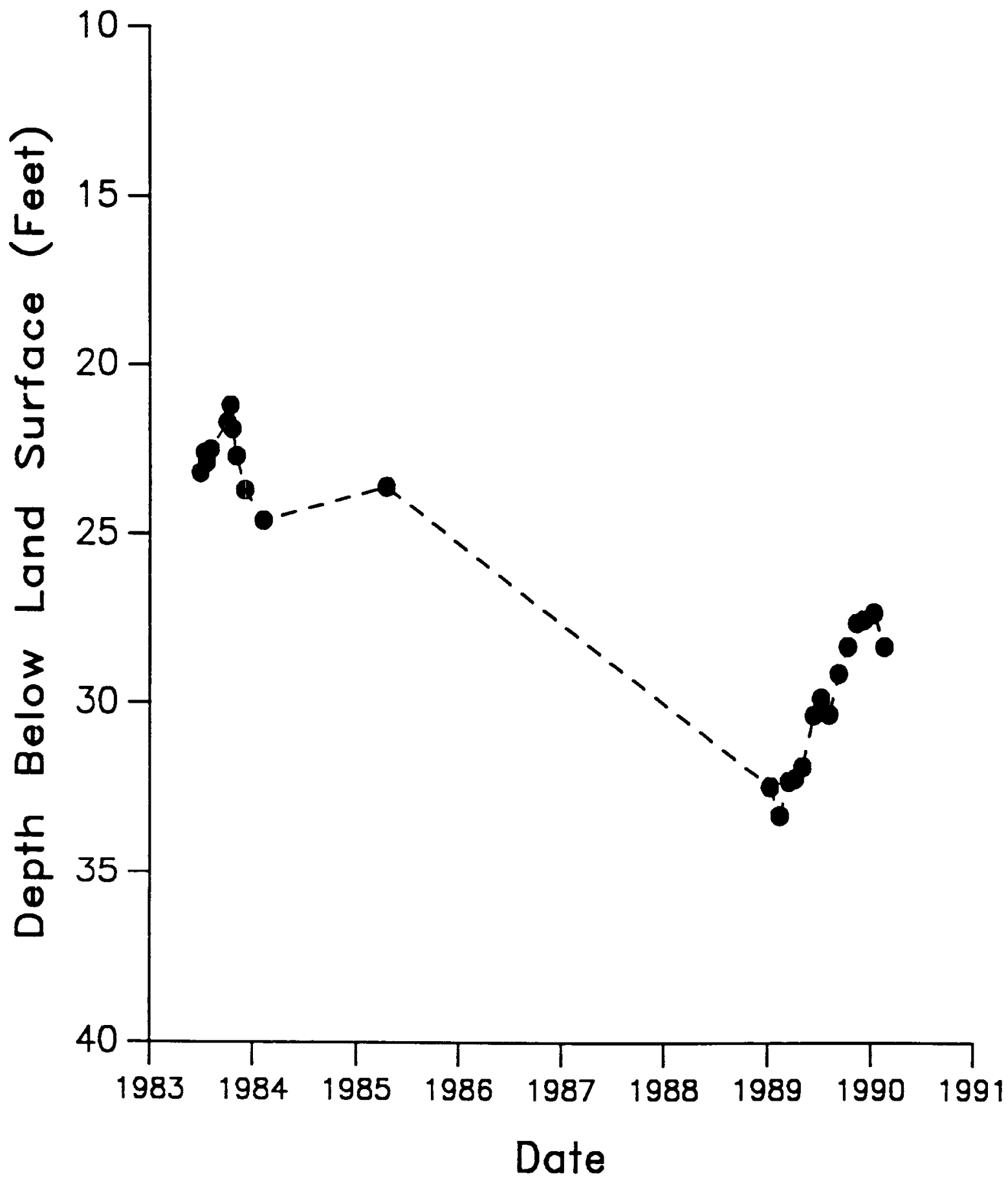




\section{WELL 26 STATIC WATER LEVEL \\ $7 / 83$ to $1 / 90$, Monitoring Well}

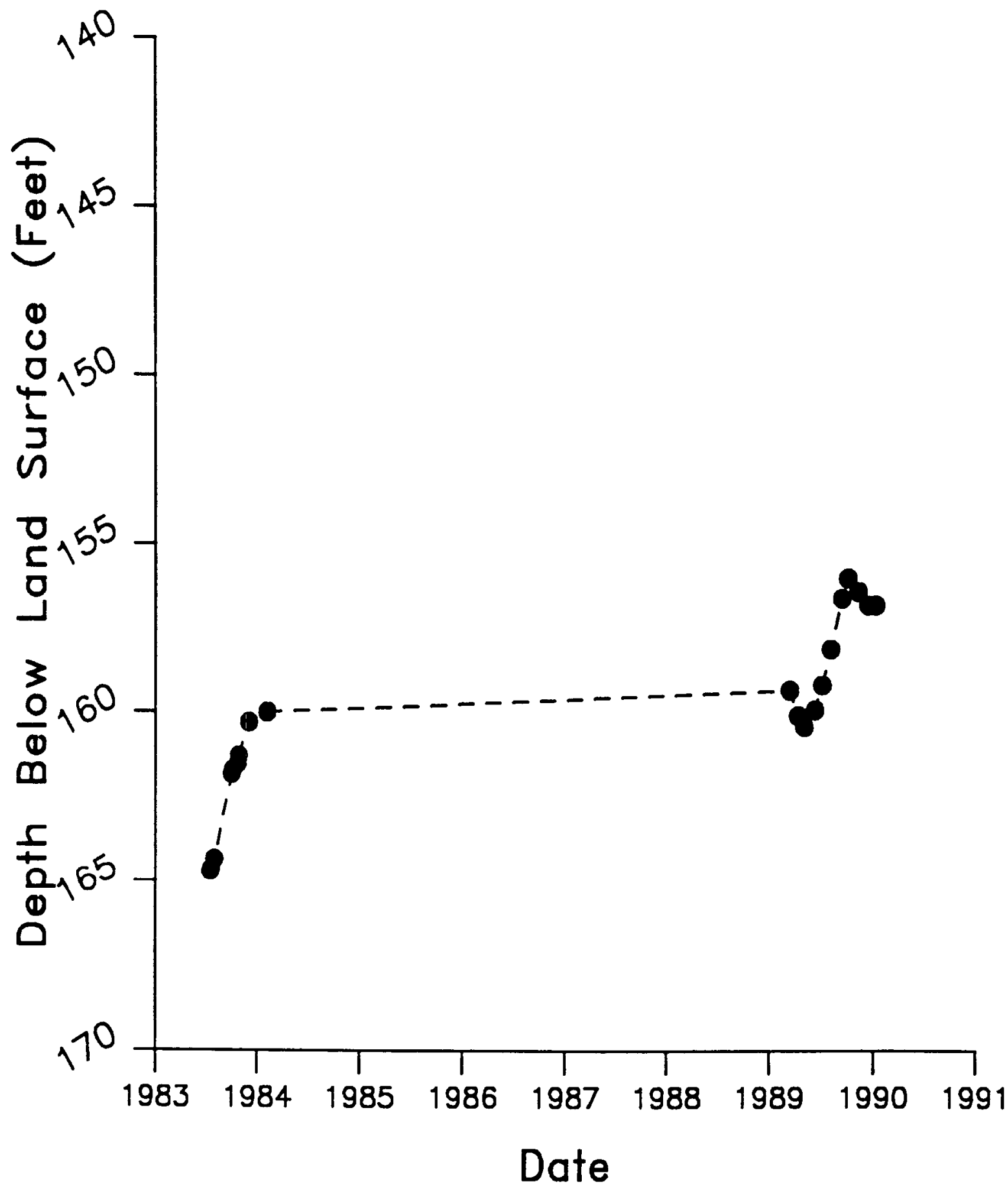




\section{APPENDIX IV}

\section{SUTRA Input Files}


EUTRA ENERGY TRANSPORT \# I input data heading -+++++++++++ Moana Geothermal Area first cut model ++++++++++++++
sacurated, steady-state

$\begin{array}{crrrrrrrrr}296 & 250 & 107 & 47 & 43 & 43 & 0 & 22 & 28 & 1 \text { \#3 sim control } \\ 0 & +1 & +1 & +1 & 0 & & & & \\ 0.0000 & & 0.010 & & & & & & & \end{array}$

\begin{tabular}{|c|c|c|c|}
\hline 1 & 86400.000 & & 0.0 \\
\hline 0 & 0 & 0 & +1 \\
\hline 30 & 10000 & 1. & \\
\hline $4.46-10$ & 4182 & .66 & 988.800 \\
\hline $1.00-7$ & 700.00 & 2.5000 & 2650.00 \\
\hline NONE & 0.0 & 0.0 & \\
\hline $\begin{array}{l}0.0000 \\
0.0000\end{array}$ & $\begin{array}{l}0.0000 \\
0.0000\end{array}$ & & \\
\hline
\end{tabular}

$$
1 \text { numerical control }
$$

1 1.0 86400.0

\# 7 output controls and opts.

\#8 iteration controls

$$
48.89 \quad-.5766 \quad 1
$$

\#10 solid properties

\# II adsorption data

\#12 energy production

NODE

$0.0000 \quad 0.0000$

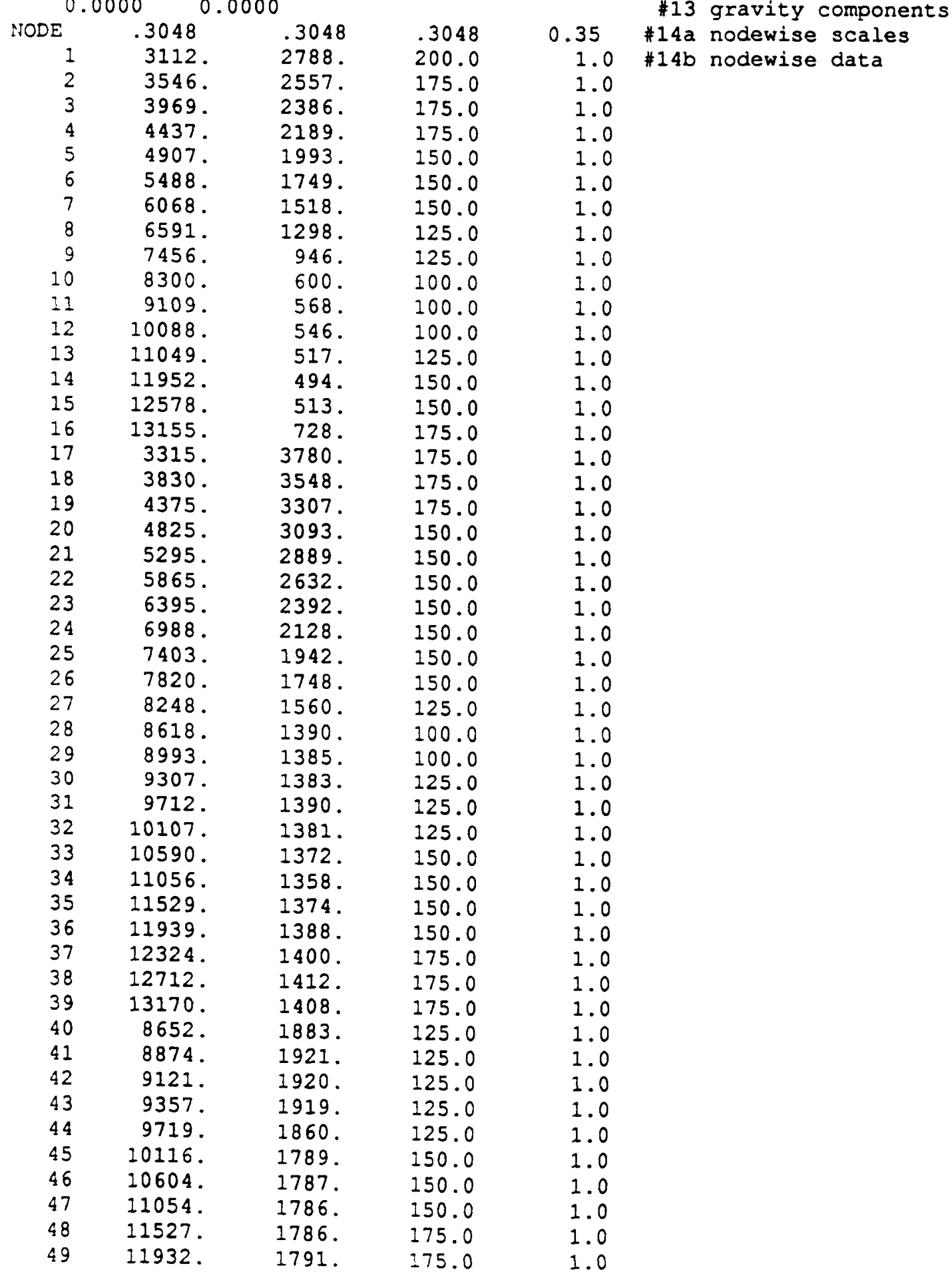




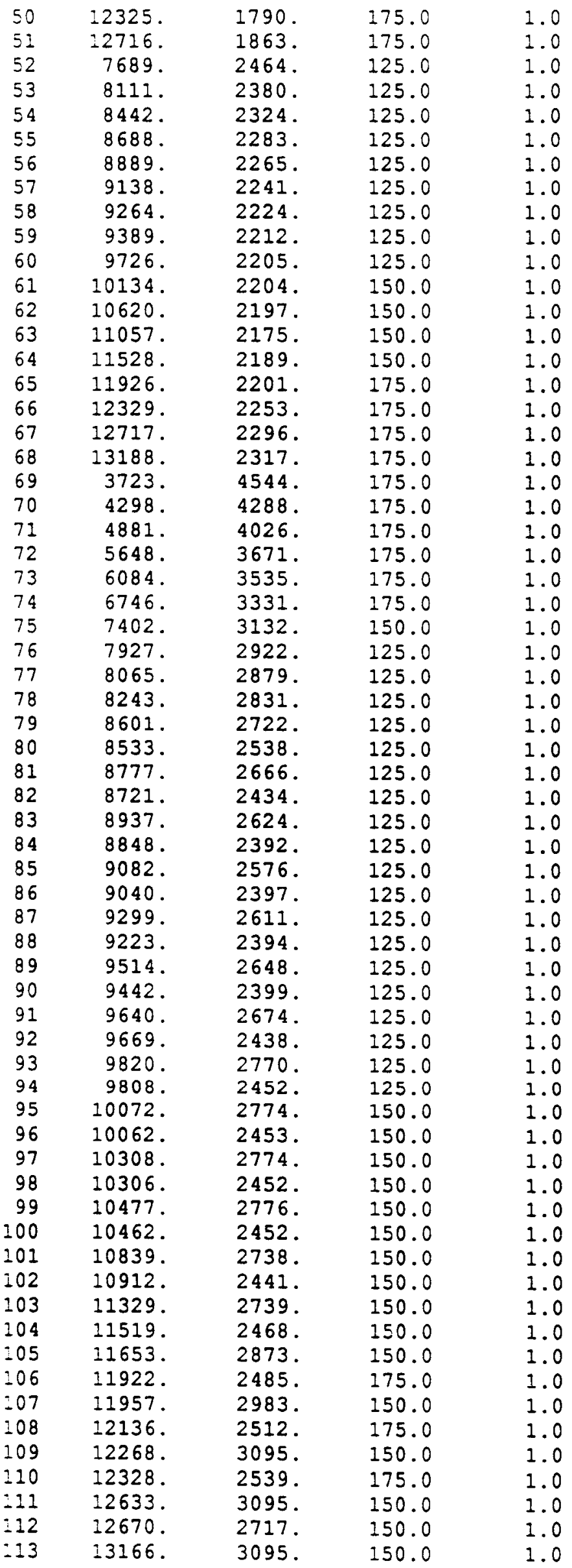




\begin{tabular}{|c|c|c|c|c|}
\hline 114 & 3953. & 4966. & 175.0 & 2.0 \\
\hline 115 & 4519. & 4745 . & 175.0 & 1.0 \\
\hline 116 & 5155. & 4579. & 175.0 & 1.0 \\
\hline 117 & 5717. & 4409 . & 175.0 & 1.0 \\
\hline 118 & 6275 . & 4186 & 150.0 & 1.0 \\
\hline 119 & 6847. & 3955. & 150.0 & 1.0 \\
\hline 120 & 7588 . & 3653 . & 125.0 & 1.0 \\
\hline 121 & 8067. & 3385 . & 125.0 & 1.0 \\
\hline 122 & 7996. & 3141. & 125.0 & 1.0 \\
\hline 123 & 8225. & 3335. & 125.0 & 1.0 \\
\hline 124 & 8120. & 3033 . & 125.0 & 1.0 \\
\hline 125 & 8388. & 3285 . & 125.0 & 1.0 \\
\hline 126 & 8285 . & 2975 . & 125.0 & 1.0 \\
\hline 127 & 8774. & 3170 . & 125.0 & 1.0 \\
\hline 128 & 8677 . & 2913. & 125.0 & 1.0 \\
\hline 129 & 8962 . & 3102 . & 125.0 & 1.0 \\
\hline 130 & 8845 . & 2848 . & 125.0 & 1.0 \\
\hline 131 & 8993. & 2833 . & 125.0 & 1.0 \\
\hline 132 & 9132. & 3077 . & 125.0 & 1.0 \\
\hline 133 & 9114. & 2829. & 125.0 & 1.0 \\
\hline 134 & 9293. & 3077 . & 125.0 & 1.0 \\
\hline 135 & 9255 . & 2824 . & 125.0 & 1.0 \\
\hline 136 & 9462 . & 3087 . & 125.0 & 1.0 \\
\hline 137 & 9454 . & 2862 . & 125.0 & 1.0 \\
\hline 138 & 9624. & 3115. & 125.0 & 1.0 \\
\hline 139 & 9631. & 2895 . & 125.0 & 1.0 \\
\hline 140 & 9823 . & 3170 . & 125.0 & 1.0 \\
\hline 141 & 9853. & 2970 . & 125.0 & 1.0 \\
\hline 142 & 10062 . & 3192 . & 150.0 & 1.0 \\
\hline 143 & 10183. & 2988 . & 150.0 & 1.0 \\
\hline 144 & 10294. & 3214 . & 150.0 & 1.0 \\
\hline 145 & 10303. & 2974 . & 150.0 & 1.0 \\
\hline 146 & 10516 & 3206 . & 150.0 & 1.0 \\
\hline 147 & 10490. & 2973. & 150.0 & 1.0 \\
\hline 148 & 10782 . & 3190. & 150.0 & 1.0 \\
\hline 149 & 10817 & 2964 . & 150.0 & 1.0 \\
\hline 150 & 11051. & 3191. & 150.0 & 1.0 \\
\hline 151 & 11177. & 2989. & 150.0 & 1.0 \\
\hline 152 & 11334. & 3217 . & 150.0 & 1.0 \\
\hline 153 & 11813 & 3291. & 150.0 & 1.0 \\
\hline 154 & 12235 & 3409 . & 150.0 & 1.0 \\
\hline 155 & 12622 . & 3437. & 150.0 & 1.0 \\
\hline 156 & 13096 & 3490. & 150.0 & 1.0 \\
\hline 157 & 4121. & 5273. & 100.0 & 1.0 \\
\hline 158 & 4830. & 5404. & 75.0 & 1.0 \\
\hline 159 & 5453 . & 5188. & 75.0 & 1.0 \\
\hline 160 & 5776 . & 5077 . & 75.0 & 1.0 \\
\hline 161 & 6465 . & 4839. & 100.0 & 1.0 \\
\hline 162 & 7118. & 4612. & 100.0 & 1.0 \\
\hline 163 & 7782 . & 4200 . & 100.0 & 1.0 \\
\hline 164 & 8213. & 4095. & 100.0 & 1.0 \\
\hline 165 & 8602 . & 4001 & 100.0 & 1.0 \\
\hline 166 & 8499 . & 3635. & 125.0 & 1.0 \\
\hline 167 & 9033. & 3858 . & 125.0 & 1.0 \\
\hline 168 & 8943 . & 3591. & 125.0 & 1.0 \\
\hline 169 & 8868 . & 3412 . & 125.0 & 1.0 \\
\hline 170 & 9084. & 3591. & 125.0 & 1.0 \\
\hline 171 & 9083. & 3325 . & 125.0 & 1.0 \\
\hline 172 & 9201. & 3858 . & 125.0 & 1.0 \\
\hline 173 & 9240. & 3591. & 125.0 & 1.0 \\
\hline 174 & 9199. & 3326 . & 125.0 & 1.0 \\
\hline 175 & 9370. & 3863. & 125.0 & 1.0 \\
\hline 176 & 9366. & 3590. & 125.0 & 1.0 \\
\hline 177 & 9337. & 3342 . & 125.0 & 1.0 \\
\hline
\end{tabular}


LAICJ.aac

\begin{tabular}{|c|c|c|c|c|}
\hline 178 & 9611. & 3829 . & 125.0 & 1.0 \\
\hline 179 & 9532. & 3597. & 125.0 & 1.0 \\
\hline 180 & 9483. & 3345 . & 125.0 & 1.0 \\
\hline 181 & 9834. & 3793. & 150.0 & 1.0 \\
\hline 182 & 9703. & 3600 . & 150.0 & 1.0 \\
\hline 183 & 9667 . & $3 ذ 45$. & 150.0 & 1.0 \\
\hline 184 & 9993. & 3786 . & 150.0 & 1.0 \\
\hline 185 & 9890. & 3615 . & 150.0 & 1.0 \\
\hline 186 & 9887. & 3405 . & 150.0 & 1.0 \\
\hline 187 & 10169. & 3765 . & 150.0 & 1.0 \\
\hline 188 & 10104. & 3625 . & 150.0 & 1.0 \\
\hline 189 & 10076. & 3412 . & 150.0 & 1.0 \\
\hline 190 & 10378. & 3780. & 150.0 & 1.0 \\
\hline 191 & 10328. & 3629. & 150.0 & 1.0 \\
\hline 192 & 10305. & 3409 . & 150.0 & 1.0 \\
\hline 193 & 10572 . & 3631. & 150.0 & 1.0 \\
\hline 194 & 10549 . & 3400 . & 150.0 & 1.0 \\
\hline 195 & 10760. & 3392 . & 150.0 & 1.0 \\
\hline 196 & 10844. & 3634 . & 150.0 & 1.0 \\
\hline 197 & 10936. & 3397. & 150.0 & 1.0 \\
\hline 198 & 11284. & 3643 . & 150.0 & 1.0 \\
\hline 199 & 11311. & 3425 . & 150.0 & 1.0 \\
\hline 200 & 11770. & 3674 . & 150.0 & 1.0 \\
\hline 201 & 12204. & 3703. & 150.0 & 1.0 \\
\hline 202 & 12604. & 3718. & 150.0 & 1.0 \\
\hline 203 & 12588. & 4027 & 150.0 & 1.0 \\
\hline 204 & 12984. & 4092 . & 150.0 & 1.0 \\
\hline 205 & 5116. & 5901. & 75.0 & 1.0 \\
\hline 206 & 5663. & 5764 . & 75.0 & 1.0 \\
\hline 207 & 6383. & 5820 . & 75.0 & 1.0 \\
\hline 208 & 6937. & 5463. & 75.0 & 1.0 \\
\hline 209 & 7580. & 5071. & 75.0 & 1.0 \\
\hline 210 & 8143. & 4655 . & 100.0 & 1.0 \\
\hline 211 & 8470 . & 4597. & 100.0 & 1.0 \\
\hline 212 & 8771. & 4553. & 100.0 & 1.0 \\
\hline 213 & 9070. & 4536 & 100.0 & 1.0 \\
\hline 214 & 9050. & 4166. & 125.0 & 1.0 \\
\hline 215 & 9312 . & 4575 . & 125.0 & 1.0 \\
\hline 216 & 9362 . & 4212 . & 125.0 & 1.0 \\
\hline 217 & 9529. & 4618 . & 125.0 & 1.0 \\
\hline 218 & 9661. & 4190. & 125.0 & 1.0 \\
\hline 219 & 9636. & 4001 . & 125.0 & 1.0 \\
\hline 220 & 9942 . & 4632 . & 125.0 & 1.0 \\
\hline 221 & 9921. & 4194 . & 125.0 & 1.0 \\
\hline 222 & 9925. & 3956 . & 125.0 & 1.0 \\
\hline 223 & 10116. & 3959. & 125.0 & 1.0 \\
\hline 224 & 10314. & 4629. & 150.0 & 1.0 \\
\hline 225 & 10321. & 4191. & 150.0 & 1.0 \\
\hline 226 & 10307. & 3958. & 150.0 & 1.0 \\
\hline 227 & 10456 & 3959. & 150.0 & 1.0 \\
\hline 228 & 10697. & 4626 & 150.0 & 1.0 \\
\hline 229 & 10646 & 4207. & 150.0 & 1.0 \\
\hline 230 & 10604. & 3949. & 150.0 & 1.0 \\
\hline 231 & 10978. & 4207. & 150.0 & 1.0 \\
\hline 232 & 10964. & 3941. & 150.0 & 1.0 \\
\hline 233 & 11306. & 4625. & 150.0 & 1.0 \\
\hline 234 & 11305 & 4217. & 150.0 & 1.0 \\
\hline 235 & 11296 & 3921. & 150.0 & 1.0 \\
\hline 236 & 11781. & 4626 & 150.0 & 1.0 \\
\hline 237 & 11758 & 4224. & 150.0 & 1.0 \\
\hline 238 & 11749 . & 3948. & 150.0 & 1.0 \\
\hline 239 & 12201 & 4243. & 150.0 & 1.0 \\
\hline 240 & 12202 . & 3954 . & 150.0 & 1.0 \\
\hline 241 & 12496 & 4648 . & 150.0 & 1.0 \\
\hline
\end{tabular}




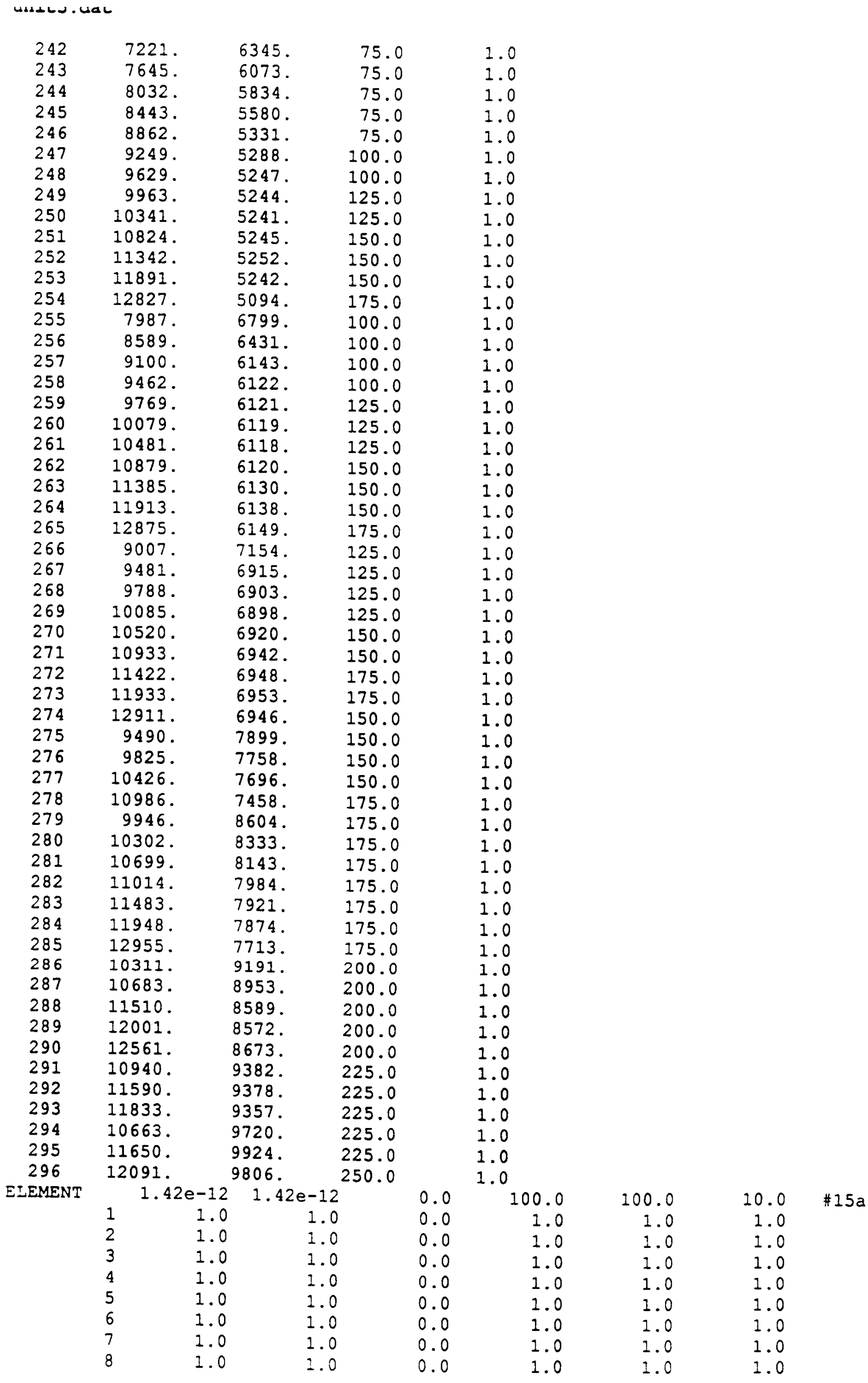




\begin{tabular}{|c|c|c|c|c|c|c|}
\hline 9 & 1.0 & 1.0 & 0.0 & 1.0 & 1.0 & 1.0 \\
\hline 20 & 1.0 & 1.0 & 0.0 & 1.0 & 1.0 & 1.0 \\
\hline 11 & 1.0 & 1.0 & 0.0 & 1.0 & 1.0 & 1.0 \\
\hline 12 & .1 .0 & 1.0 & 0.0 & 1.0 & 1.0 & 1.0 \\
\hline 13 & 1.0 & 1.0 & 0.0 & 1.0 & 1.0 & 1.0 \\
\hline 14 & 1.0 & 1.0 & 0.0 & 1.0 & 1.0 & 1.0 \\
\hline 15 & 1.0 & 1.0 & 0.0 & 1.0 & 1.0 & 1.0 \\
\hline 16 & 1.0 & 1.0 & 0.0 & 1.0 & 1.0 & 1.0 \\
\hline 17 & 1.0 & 1.0 & 0.0 & 1.0 & 1.0 & 1.0 \\
\hline 18 & 1.0 & 1.0 & 0.0 & 1.0 & 1.0 & 1.0 \\
\hline 19 & 1.0 & 1.0 & 0.0 & 1.0 & 1.0 & 1.0 \\
\hline 20 & 1.0 & 1.0 & 0.0 & 1.0 & 1.0 & 1.0 \\
\hline 21 & 1.0 & 1,0 & 0.0 & 1.0 & 1.0 & 1.0 \\
\hline 22 & 1.0 & 1.0 & 0.0 & 1.0 & 1.0 & 1.0 \\
\hline 23 & 1.0 & 1.0 & 0.0 & 1.0 & 1.0 & 1.0 \\
\hline 24 & 1.0 & 1.0 & 0.0 & 1.0 & 1.0 & 1.0 \\
\hline 25 & 1.0 & 1.0 & 0.0 & 1.0 & 1.0 & 1.0 \\
\hline 26 & 1.0 & 1.0 & 0.0 & 1.0 & 1.0 & 1.0 \\
\hline 27 & 1.0 & 1.0 & 0.0 & 1.0 & 1.0 & 1.0 \\
\hline 28 & 1.0 & 1.0 & 0.0 & 1.0 & 1.0 & 1.0 \\
\hline 29 & 1.0 & $1: 0$ & 0.0 & 1.0 & 1.0 & 1.0 \\
\hline 30 & 1.0 & 1.0 & 0.0 & 1.0 & 1.0 & 1.0 \\
\hline 31 & 1.0 & 1.0 & 0.0 & 1.0 & 1.0 & 1.0 \\
\hline 32 & 1.0 & 1.0 & 0.0 & 1.0 & 1.0 & 1.0 \\
\hline 33 & 1.0 & 1.0 & 0.0 & 1.0 & 1.0 & 1.0 \\
\hline 34 & 1.0 & 1.0 & 0.0 & 1.0 & 1.0 & 1.0 \\
\hline 35 & 1.0 & 1.0 & 0.0 & 1.0 & 1.0 & 1.0 \\
\hline 36 & 1.0 & 1.0 & 0.0 & 1.0 & 1.0 & 1.0 \\
\hline 37 & 1.0 & 1.0 & 0.0 & 1.0 & 1.0 & 2.0 \\
\hline 38 & 1.0 & 1.0 & 0.0 & 1.0 & 1.0 & 1.0 \\
\hline 39 & 1.0 & 1.0 & 0.0 & 1.0 & 1.0 & 1.0 \\
\hline 40 & 1.0 & 1.0 & 0.0 & 1.0 & 1.0 & 1.0 \\
\hline 41 & 1.0 & 1.0 & 0.0 & 1.0 & 1.0 & 1.0 \\
\hline 42 & 1.0 & 1.0 & 0.0 & 1.0 & 1.0 & 1.0 \\
\hline 43 & 1.0 & 1.0 & 0.0 & 1.0 & 1.0 & 1.0 \\
\hline 44 & 1.0 & 1.0 & 0.0 & 1.0 & 1.0 & 1.0 \\
\hline 45 & 1.0 & 1.0 & 0.0 & 1.0 & 1.0 & 1.0 \\
\hline 46 & 1.0 & 1.0 & 0.0 & 1.0 & 1.0 & 1.0 \\
\hline 47 & 1.0 & 1.0 & 0.0 & 1.0 & 1.0 & 1.0 \\
\hline 48 & 1.0 & 1.0 & 0.0 & 1.0 & 1.0 & 1.0 \\
\hline 49 & 1.0 & 1.0 & 0.0 & 1.0 & 1.0 & 1.0 \\
\hline 50 & 1.0 & 1.0 & 0.0 & 1.0 & 1.0 & 1.0 \\
\hline 51 & 1.0 & 1.0 & 0.0 & 1.0 & 1.0 & 1.0 \\
\hline 52 & 1.0 & 1.0 & 0.0 & 1.0 & 1.0 & 1.0 \\
\hline 53 & 1.0 & 1.0 & 0.0 & 1.0 & 1.0 & 1.0 \\
\hline 54 & 1.0 & 1.0 & 0.0 & 1.0 & 1.0 & 1.0 \\
\hline 55 & 1.0 & 1.0 & 0.0 & 1.0 & 1.0 & 1.0 \\
\hline 56 & 1.0 & 1.0 & 0.0 & 1.0 & 1.0 & 1.0 \\
\hline 57 & 1.0 & 1.0 & 0.0 & 1.0 & 1.0 & 1.0 \\
\hline 38 & 1.0 & 1.0 & 0.0 & 1.0 & 1.0 & 1.0 \\
\hline 5 & 1.0 & 1.0 & 0.0 & 1.0 & 1.0 & 1.0 \\
\hline 0 & 1.0 & 1.0 & 0.0 & 1.0 & 1.0 & 1.0 \\
\hline 1 & 1.0 & 1.0 & 0.0 & 1.0 & 1.0 & 1.0 \\
\hline 2 & 1.0 & 1.0 & 0.0 & 1.0 & 1.0 & 1.0 \\
\hline$=$ & 1.0 & 1.0 & 0.0 & 1.0 & 1.0 & 1.0 \\
\hline 4 & 1.0 & 1.0 & 0.0 & 1.0 & 1.0 & 1.0 \\
\hline 5 & 1.0 & 1.0 & 0.0 & 1.0 & 1.0 & 1.0 \\
\hline 6 & 1.0 & 1.0 & 0.0 & 1.0 & 1.0 & 1.0 \\
\hline 7 & 1.0 & 1.0 & 0.0 & 1.0 & 1.0 & 1.0 \\
\hline 8 & 1.0 & 1.0 & 0.0 & 1.0 & 1.0 & 1.0 \\
\hline 9 & 1.0 & 1.0 & 0.0 & 1.0 & 1.0 & 1.0 \\
\hline 0 & 1.0 & 1.0 & 0.0 & 1.0 & 1.0 & 1.0 \\
\hline 1 & 1.0 & 1.0 & 0.0 & 1.0 & 1.0 & 1.0 \\
\hline 2 & 1.0 & 1.0 & 0.0 & 1.0 & 1.0 & 1.0 \\
\hline
\end{tabular}




\begin{tabular}{|c|c|c|c|c|c|c|}
\hline 73 & 1.0 & 1.0 & 0.0 & 1.0 & 1.0 & 1.0 \\
\hline 74 & 1.0 & 1.0 & 0.0 & 1.0 & 1.0 & 1.0 \\
\hline 75 & 1.0 & 1.0 & 0.0 & 1.0 & 1.0 & 1.0 \\
\hline 76 & 1.0 & 1.0 & 0.0 & 1.0 & 1.0 & 1.0 \\
\hline 77 & 1.0 & 1.0 & 0.0 & 1.0 & 1.0 & 1.0 \\
\hline 78 & 1.0 & 1.0 & 0.0 & 1.0 & 1.0 & 1.0 \\
\hline 79 & 1.0 & 1.0 & 0.0 & 1.0 & 1.0 & 1.0 \\
\hline 80 & 1.0 & 1.0 & 0.0 & 1.0 & 1.0 & 1.0 \\
\hline 81 & 1.0 & 1.0 & 0.0 & 1.0 & 1.0 & 1.0 \\
\hline 82 & 1.0 & 1.0 & 0.0 & 1.0 & 1.0 & 1.0 \\
\hline 83 & 1.0 & 1.0 & 0.0 & 1.0 & 1.0 & 1.0 \\
\hline 84 & 1.0 & 1.0 & 0.0 & 1.0 & 1.0 & 1.0 \\
\hline 85 & 1.0 & 1.0 & 0.0 & 1.0 & 1.0 & 1.0 \\
\hline 86 & 1.0 & 1.0 & 0.0 & 1.0 & 1.0 & 1.0 \\
\hline 87 & 1.0 & 1.0 & 0.0 & 1.0 & 1.0 & 1.0 \\
\hline 88 & 1.0 & 1.0 & 0.0 & 1.0 & 1.0 & 1.0 \\
\hline 89 & 1.0 & 1.0 & 0.0 & 1.0 & 1.0 & 1.0 \\
\hline 90 & 1.0 & 1.0 & 0.0 & 1.0 & 1.0 & 1.0 \\
\hline 91 & 1.0 & 1.0 & 0.0 & 1.0 & 1.0 & 1.0 \\
\hline 92 & 1.0 & 1.0 & 0.0 & 1.0 & 1.0 & 1.0 \\
\hline 93 & 1.0 & 1.0 & 0.0 & 1.0 & 1.0 & 1.0 \\
\hline 94 & 1.0 & 1.0 & 0.0 & 1.0 & 1.0 & 1.0 \\
\hline 95 & 1.0 & 1.0 & 0.0 & 1.0 & 1.0 & 1.0 \\
\hline 96 & 1.0 & 1.0 & 0.0 & 1.0 & 1.0 & 1.0 \\
\hline 97 & 1.0 & 1.0 & 0.0 & 1.0 & 1.0 & 1.0 \\
\hline 98 & 1.0 & 1.0 & 0.0 & 1.0 & 1.0 & 1.0 \\
\hline 99 & 1.0 & 1.0 & 0.0 & 1.0 & 1.0 & 1.0 \\
\hline 100 & 1.0 & 1.0 & 0.0 & 1.0 & 1.0 & 1.0 \\
\hline 101 & 1.0 & 1.0 & 0.0 & 1.0 & 1.0 & 1.0 \\
\hline 102 & 1.0 & 1.0 & 0.0 & 1.0 & 1.0 & 1.0 \\
\hline 103 & 1.0 & 1.0 & 0.0 & 1.0 & 1.0 & 1.0 \\
\hline 104 & 1.0 & 1.0 & 0.0 & 1.0 & 1.0 & 1.0 \\
\hline 105 & 1.0 & 1.0 & 0.0 & 1.0 & 1.0 & 1.0 \\
\hline 106 & 1.0 & 1.0 & 0.0 & 1.0 & 1.0 & 1.0 \\
\hline 107 & 1.0 & 1.0 & 0.0 & 1.0 & 1.0 & 1.0 \\
\hline 108 & 1.0 & 1.0 & 0.0 & 1.0 & 1.0 & 1.0 \\
\hline 109 & 1.0 & 1.0 & 0.0 & 1.0 & 1.0 & 1.0 \\
\hline 110 & 1.0 & 1.0 & 0.0 & 1.0 & 1.0 & 1.0 \\
\hline 111 & 1.0 & 1.0 & 0.0 & 1.0 & 1.0 & 1.0 \\
\hline 112 & 1.0 & 1.0 & 0.0 & 1.0 & 1.0 & 1.0 \\
\hline 113 & 1.0 & 1.0 & 0.0 & 1.0 & 1.0 & 1.0 \\
\hline 114 & 1.0 & 1.0 & 0.0 & 1.0 & 1.0 & 1.0 \\
\hline 115 & 1.0 & 1.0 & 0.0 & 1.0 & 1.0 & 1.0 \\
\hline 116 & 1.0 & 1.0 & 0.0 & 1.0 & 1.0 & 1.0 \\
\hline 117 & 1.0 & 1.0 & 0.0 & 1.0 & 1.0 & 1.0 \\
\hline 118 & 1.0 & 1.0 & 0.0 & 1.0 & 1.0 & 1.0 \\
\hline 119 & 1.0 & 1.0 & 0.0 & 1.0 & 1.0 & 1.0 \\
\hline 120 & 1.0 & 1.0 & 0.0 & 1.0 & 1.0 & 1.0 \\
\hline 121 & 1.0 & 1.0 & 0.0 & 1.0 & 1.0 & 1.0 \\
\hline 122 & 1.0 & 1.0 & 0.0 & 1.0 & 1.0 & 1.0 \\
\hline 123 & 1.0 & 1.0 & 0.0 & 1.0 & 1.0 & 1.0 \\
\hline 124 & 1.0 & 1.0 & 0.0 & 1.0 & 1.0 & 1.0 \\
\hline 125 & 1.0 & 1.0 & 0.0 & 1.0 & 1.0 & 1.0 \\
\hline 126 & 1.0 & 1.0 & 0.0 & 1.0 & 1.0 & 1.0 \\
\hline 127 & 1.0 & 1.0 & 0.0 & 1.0 & 1.0 & 1.0 \\
\hline 128 & 1.0 & 1.0 & 0.0 & 1.0 & 1.0 & 1.0 \\
\hline 129 & 1.0 & 1.0 & 0.0 & 1.0 & 1.0 & 1.0 \\
\hline 130 & 1.0 & 1.0 & 0.0 & 1.0 & 1.0 & 1.0 \\
\hline 131 & 1.0 & 1.0 & 0.0 & 1.0 & 1.0 & 1.0 \\
\hline 132 & 1.0 & 1.0 & 0.0 & 1.0 & 1.0 & 1.0 \\
\hline 133 & 1.0 & 1.0 & 0.0 & 1.0 & 1.0 & 1.0 \\
\hline 134 & 1.0 & 1.0 & 0.0 & 1.0 & 1.0 & 1.0 \\
\hline 135 & 1.0 & 1.0 & 0.0 & 1.0 & 1.0 & 1.0 \\
\hline 136 & 1.0 & 1.0 & 0.0 & 1.0 & 1.0 & 1.0 \\
\hline
\end{tabular}




\begin{tabular}{|c|c|c|c|c|c|c|}
\hline 137 & 1.0 & 2.0 & 0.0 & 1.0 & 1.0 & 1.0 \\
\hline 138 & 1.0 & 1.0 & 0.0 & 1.0 & 1.0 & 1.0 \\
\hline 139 & 1.0 & 1.0 & 0.0 & 1.0 & 1.0 & 1.0 \\
\hline 140 & 1.0 & 1.0 & 0.0 & 1.0 & 1.0 & 1.0 \\
\hline 141 & 1.0 & 1.0 & 0.0 & 1.0 & 1.0 & 1.0 \\
\hline 142 & 1.0 & 1.0 & 0.0 & 1.0 & 1.0 & 1.0 \\
\hline 143 & 1.0 & 1.0 & 0.0 & 1.0 & 1.0 & 1.0 \\
\hline 144 & 1.0 & 1.0 & 0.0 & 1.0 & 1.0 & 1.0 \\
\hline 145 & 1.0 & 1.0 & 0.0 & 1.0 & 1.0 & 1.0 \\
\hline 146 & 1.0 & 1.0 & 0.0 & 1.0 & 1.0 & 1.0 \\
\hline 147 & 1.0 & 1.0 & 0.0 & 1.0 & 1.0 & 1.0 \\
\hline 148 & 1.0 & 1.0 & 0.0 & 1.0 & 1.0 & 1.0 \\
\hline 149 & 1.0 & 1.0 & 0.0 & 1.0 & 1.0 & 1.0 \\
\hline 150 & 1.0 & 1.0 & 0.0 & 1.0 & 1.0 & 1.0 \\
\hline 151 & 1.0 & 1.0 & 0.0 & 1.0 & 1.0 & 1.0 \\
\hline 152 & 1.0 & 1.0 & 0.0 & 1.0 & 1.0 & 1.0 \\
\hline 153 & 1.0 & 1.0 & 0.0 & 1.0 & 1.0 & 1.0 \\
\hline 154 & 1.0 & 1.0 & 0.0 & 1.0 & 1.0 & 1.0 \\
\hline 155 & 1.0 & 1.0 & 0.0 & 1.0 & 1.0 & 1.0 \\
\hline 156 & 1.0 & 1.0 & 0.0 & 1.0 & 1.0 & 1.0 \\
\hline 157 & 1.0 & 1.0 & 0.0 & 1.0 & 1.0 & 1.0 \\
\hline 158 & 1.0 & 1.0 & 0.0 & 1.0 & 1.0 & 1.0 \\
\hline 159 & 1.0 & 1.0 & 0.0 & 1.0 & 1.0 & 1.0 \\
\hline 160 & 1.0 & 1.0 & 0.0 & 1.0 & 1.0 & 1.0 \\
\hline 161 & 1.0 & 1.0 & 0.0 & 1.0 & 1.0 & 1.0 \\
\hline 162 & 1.0 & 1.0 & 0.0 & 1.0 & 1.0 & 1.0 \\
\hline 163 & 1.0 & 1.0 & 0.0 & 1.0 & 1.0 & 1.0 \\
\hline 164 & 1.0 & 1.0 & 0.0 & 1.0 & 1.0 & 1.0 \\
\hline 165 & 1.0 & 1.0 & 0.0 & 1.0 & 1.0 & 1.0 \\
\hline 166 & 1.0 & 1.0 & 0.0 & 1.0 & 1.0 & 1.0 \\
\hline 167 & 1.0 & 1.0 & 0.0 & 1.0 & 1.0 & 1.0 \\
\hline 168 & 1.0 & 1.0 & 0.0 & 1.0 & 1.0 & 1.0 \\
\hline 169 & 1.0 & 1.0 & 0.0 & 1.0 & 1.0 & 1.0 \\
\hline 170 & 1.0 & 1.0 & 0.0 & 1.0 & 1.0 & 1.0 \\
\hline 171 & 1.0 & 1.0 & 0.0 & 1.0 & 1.0 & 1.0 \\
\hline 172 & 1.0 & 1.0 & 0.0 & 1.0 & 1.0 & 1.0 \\
\hline 173 & 1.0 & 1.0 & 0.0 & 1.0 & 1.0 & 1.0 \\
\hline 174 & 1.0 & 1.0 & 0.0 & 1.0 & 1.0 & 1.0 \\
\hline 175 & 1.0 & 1.0 & 0.0 & 1.0 & 1.0 & 1.0 \\
\hline 176 & 1.0 & 1.0 & 0.0 & 1.0 & 1.0 & 1.0 \\
\hline 177 & 1.0 & 1.0 & 0.0 & 1.0 & 1.0 & 1.0 \\
\hline 178 & 1.0 & 1.0 & 0.0 & 1.0 & 1.0 & 1.0 \\
\hline 179 & 1.0 & 1.0 & 0.0 & 1.0 & 1.0 & 1.0 \\
\hline 180 & 1.0 & 1.0 & 0.0 & 1.0 & 1.0 & 1.0 \\
\hline 181 & 1.0 & 1.0 & 0.0 & 1.0 & 1.0 & 1.0 \\
\hline 182 & 1.0 & 1.0 & 0.0 & 1.0 & 1.0 & 1.0 \\
\hline 183 & 1.0 & 1.0 & 0.0 & 1.0 & 1.0 & 1.0 \\
\hline 184 & 1.0 & 1.0 & 0.0 & 1.0 & 1.0 & 1.0 \\
\hline 185 & 1.0 & 1.0 & 0.0 & 1.0 & 1.0 & 1.0 \\
\hline 186 & 1.0 & 1.0 & 0.0 & 1.0 & 1.0 & 1.0 \\
\hline 187 & 1.0 & 1.0 & 0.0 & 1.0 & 1.0 & 1.0 \\
\hline 188 & 1.0 & 1.0 & 0.0 & 1.0 & 1.0 & 1.0 \\
\hline 189 & 1.0 & 1.0 & 0.0 & 1.0 & 1.0 & 1.0 \\
\hline 190 & 1.0 & 1.0 & 0.0 & 1.0 & 1.0 & 1.0 \\
\hline 191 & 1.0 & 1.0 & 0.0 & 1.0 & 1.0 & 1.0 \\
\hline 192 & 1.0 & 1.0 & 0.0 & 1.0 & 1.0 & 1.0 \\
\hline 193 & 1.0 & 1.0 & 0.0 & 1.0 & 1.0 & 1.0 \\
\hline 194 & 1.0 & 1.0 & 0.0 & 1.0 & 1.0 & 1.0 \\
\hline 195 & 1.0 & 1.0 & 0.0 & 1.0 & 1.0 & 1.0 \\
\hline 196 & 1.0 & 1.0 & 0.0 & 1.0 & 1.0 & 1.0 \\
\hline 197 & 1.0 & 1.0 & 0.0 & 1.0 & 1.0 & 1.0 \\
\hline 198 & 1.0 & 1.0 & 0.0 & 1.0 & 1.0 & 1.0 \\
\hline 199 & 1.0 & 1.0 & 0.0 & 1.0 & 1.0 & 1.0 \\
\hline 200 & 1.0 & 1.0 & 0.0 & 1.0 & 1.0 & 1.0 \\
\hline
\end{tabular}




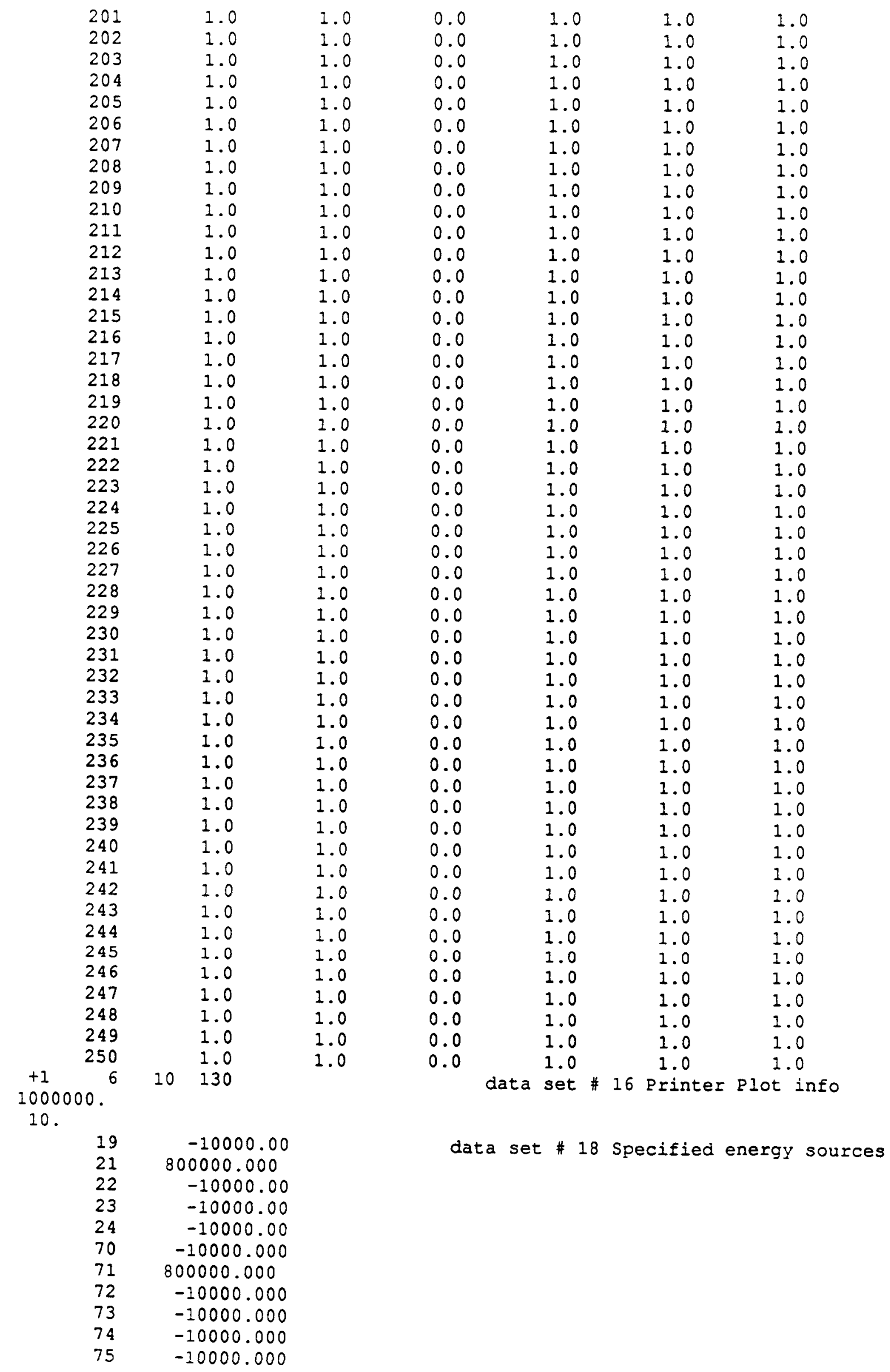




$\begin{array}{rr}93 & 25000.000 \\ 115 & 400000.000 \\ 116 & 400000.000 \\ 117 & -10000.000 \\ 118 & -10000.000 \\ 119 & -10000.000 \\ 141 & 25000.000 \\ 142 & 25000.000 \\ 187 & 25000.000 \\ 188 & 25000.000 \\ 189 & 25000.000\end{array}$

1347216.00

1380744.00

1322832.00

1292352.00

1219200.00

1100328.00

1045464.00

984504.00

987552.00

1011936.00

1005840.00

941832.00

886968.00

847344.00

835152.00

777240.00

771144.00

762000.00

755904.00

746760.00

746760.00

746760.00

731520.00

716280.00

716280.00

716280.00

716280.00

731520.00

743712.00

755048.00

822960.00

838200.00

868680.00

917448.00

966216.00

1018032.00

1057656.00

1088136.00

1115568.00

1161288.00

1197864.00

1234440.00

1328928.00
28.00

35.50

40.00

60.00

80.00

83.00

80.00

83.00

80.00

60.00

50.00

58.00

48.00

42.00

36.00

30.00

30.00

30.00

30.00

30.00

30.00

30.00

30.00

30.00

30.00

31.00

32.00

34.00

39.50

46.00

58.00

59.00

53.00

49.00

65.00

77.00

82.00

82.00

85.00

80.00

70.00

58.00

33.00

28.0
35.5
40.0
60.0
80.0
83.0
80.0
83.0

data set \# 19

Specified pressures on boundaries

* 20 Specified temps on boundaries 
unit5.dat

$\begin{array}{rr}9 & 80.0 \\ 10 & 60.0 \\ 11 & 50.0 \\ 12 & 58.0 \\ 13 & 48.0 \\ 14 & 42.0 \\ 15 & 36.0 \\ 16 & 30.0 \\ 39 & 30.0 \\ 68 & 30.0 \\ 113 & 30.0 \\ 156 & 30.0 \\ 204 & 30.0 \\ 254 & 30.0 \\ 265 & 30.0 \\ 274 & 30.0 \\ 285 & 30.0 \\ 290 & 31.0 \\ 296 & 32.0 \\ 295 & 34.0 \\ 294 & 39.5 \\ 286 & 46.0 \\ 279 & 58.0 \\ 275 & 59.0 \\ 266 & 53.0 \\ 255 & 49.0 \\ 242 & 65.0 \\ 207 & 77.0 \\ 206 & 82.0 \\ 205 & 82.0 \\ 158 & 85.0 \\ 157 & 80.0 \\ 114 & 70.0 \\ 69 & 58.0 \\ 17 & 33.0\end{array}$

$$
\begin{aligned}
& \begin{array}{rrrrrrrrrrrrrrrr}
163 & 162 & 226 & 124 & 93 & 89 & 144 & 140 & 250 & 180 & 177 & 135 & 66 & 143 & 145 & 2 \\
86 & 56 & 133 & 181 & 201 & 53 & 138 & 294 & 275 & 222 & 216 & 24 & 0 & 0 & 0 & 0
\end{array} \\
& \begin{array}{llll}
17 & 1 & 2 & \text { data set \#22 element information }
\end{array} \\
& \begin{array}{lllll}
3 & 20 & 19 & 3 & 4
\end{array} \\
& \begin{array}{lllll}
4 & 21 & 20 & 4 & 5
\end{array} \\
& \begin{array}{lllll}
5 & 22 & 21 & 5 & 6
\end{array} \\
& \begin{array}{lllll}
6 & 23 & 22 & 6 & 7
\end{array} \\
& \begin{array}{rrrrr}
7 & 24 & 23 & 7 & 8 \\
-8 & 26 & 24 & 8 & 9
\end{array} \\
& 25 \quad 26 \quad 24 \quad 8000 \\
& \begin{array}{rllll}
-9 & 28 & 26 & 9 & 10
\end{array} \\
& \begin{array}{rrrrr}
-10 & 30 & 28 & 10 & 11
\end{array} \\
& \begin{array}{lllll}
-11 & 32 & 30 & 11 & 12
\end{array} \\
& \begin{array}{rrrrr}
31 & 32 & 34 & 32 & 12
\end{array} \\
& \begin{array}{rrrrr}
33 & & & & \\
-13 & 36 & 34 & 13 & 14
\end{array} \\
& \begin{array}{lllll}
35 & & & & \\
14 & 37 & 36 & 14 & 15
\end{array} \\
& \begin{array}{lllll}
-15 & 39 & 37 & 15 & 16
\end{array} \\
& \begin{array}{lllll}
38 & & & & \\
16 & 70 & 69 & 17 & 18
\end{array} \\
& \begin{array}{lllll}
16 & 70 & 69 & 17 & 18 \\
17 & 71 & 70 & 18 & 19
\end{array} \\
& \begin{array}{lllll}
-18 & 72 & 71 & 19 & 21
\end{array}
\end{aligned}
$$


unit5.dat

$\begin{array}{rrrrr} & & 20 & & \\ 19 & 73 & 72 & 21 & 22 \\ 20 & 74 & 73 & 22 & 23 \\ 21 & 75 & 74 & 23 & 24 \\ -22 & 76 & 75 & 24 & 25 \\ 23 & 53 & 52 & 52 & \\ 24 & 54 & 53 & 26 & 26 \\ -25 & 55 & 54 & 27 & 28 \\ & & & 40 & \\ 26 & 41 & 40 & 28 & 29 \\ -27 & 43 & 41 & 29 & 30 \\ & 42 & & & \\ 28 & 44 & 43 & 30 & 31 \\ 29 & 45 & 44 & 31 & 32 \\ 30 & 46 & 45 & 32 & 33 \\ 31 & 47 & 46 & 33 & 34 \\ 32 & 48 & 47 & 34 & 35 \\ 33 & 49 & 48 & 35 & 36 \\ 34 & 50 & 49 & 36 & 37 \\ 35 & 51 & 50 & 37 & 38 \\ 36 & 56 & 55 & 40 & 41 \\ 37 & 57 & 56 & 41 & 42 \\ -38 & 59 & 57 & 42 & 43 \\ 58 & & & & \\ 39 & 60 & 59 & 43 & 44 \\ 40 & 61 & 60 & 44 & 45 \\ 41 & 62 & 61 & 45 & 46 \\ 42 & 63 & 62 & 46 & 47 \\ 43 & 64 & 63 & 47 & 48 \\ 44 & 65 & 64 & 48 & 49 \\ 45 & 66 & 65 & 49 & 50 \\ 46 & 67 & 66 & 50 & 51 \\ -47 & 68 & 67 & 38 & 39 \\ & 51 & & & \\ -48 & 78 & 76 & 52 & 53 \\ 77 & & & & \\ -49 & 79 & 78 & 53 & 54 \\ 52 & 112 & 110 & 66 & 67 \\ 53 & 81 & 79 & 80 & 82 \\ 64 & 83 & 81 & 82 & 84 \\ 65 & 85 & 83 & 84 & 86 \\ 66 & 87 & 85 & 86 & 88 \\ 67 & 89 & 87 & 88 & 90 \\ 68 & 91 & 89 & 90 & 92 \\ 69 & 93 & 91 & 92 & 94 \\ 70 & 95 & 93 & 94 & 96 \\ 71 & 97 & 95 & 96 & 98 \\ 51 & 84 & 80 & 54 & 55 \\ 52 & 86 & 84 & 55 & 56 \\ 53 & 88 & 86 & 57 & 58 \\ 54 & 90 & 88 & 58 & 59 \\ -55 & 94 & 90 & 58 & 60 \\ 92 & & & & \\ 56 & 96 & 94 & 60 & 61 \\ -57 & 100 & 96 & 61 & 62 \\ 98 & & & & \\ 58 & 102 & 100 & 62 & 63 \\ 59 & 104 & 102 & 63 & 64 \\ 60 & 106 & 104 & 64 & 65 \\ 108 & 110 & 106 & 65 & 66 \\ & & & & \end{array}$




\begin{tabular}{|c|c|c|c|c|}
\hline 12 & 99 & 97 & 98 & 100 \\
\hline 73 & 101 & 99 & 100 & 102 \\
\hline 74 & 103 & 101 & 102 & 104 \\
\hline 75 & 105 & 103 & 104 & 06 \\
\hline 76 & 107 & 105 & 106 & 08 \\
\hline 77 & 109 & 107 & 108 & 10 \\
\hline 78 & 111 & 109 & 110 & 112 \\
\hline-79 & $\begin{array}{l}113 \\
112\end{array}$ & 111 & 67 & 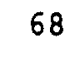 \\
\hline 80 & 115 & 114 & 69 & 70 \\
\hline 81 & 116 & 115 & 70 & 71 \\
\hline 82 & 117 & 116 & 71 & 72 \\
\hline 83 & 118 & 117 & 72 & 73 \\
\hline 84 & 119 & 118 & 73 & 74 \\
\hline 85 & 120 & 119 & 74 & 75 \\
\hline-86 & 121 & 120 & 75 & 7 \\
\hline & & & 122 & \\
\hline 87 & 124 & 122 & 76 & 77 \\
\hline 88 & 126 & 124 & 77 & $7 \varepsilon$ \\
\hline 89 & 128 & 126 & 78 & $r=$ \\
\hline 90 & 130 & 128 & 79 & 81 \\
\hline 91 & 131 & 130 & 81 & 83 \\
\hline 92 & 133 & 131 & 83 & 85 \\
\hline 93 & 135 & 133 & 85 & 87 \\
\hline 94 & 137 & 135 & 87 & 89 \\
\hline 95 & 139 & 137 & 89 & 9. \\
\hline 96 & 141 & 139 & 91 & 9 \\
\hline 97 & 143 & 141 & 93 & 9 \\
\hline 98 & 145 & 143 & 95 & 9 \\
\hline 99 & 147 & 145 & 97 & 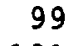 \\
\hline 100 & 149 & 147 & 99 & 10 \\
\hline 101 & 151 & 149 & 101 & 10 \\
\hline 102 & 123 & 121 & 122 & 124 \\
\hline 103 & 125 & 123 & 124 & 12 \\
\hline 104 & 127 & 125 & 126 & 12 \\
\hline 105 & 129 & 127 & 128 & 130 \\
\hline-106 & 132 & $\begin{array}{l}129 \\
131\end{array}$ & 130 & 133 \\
\hline 107 & 134 & 132 & 133 & 135 \\
\hline 108 & 136 & 134 & 135 & 137 \\
\hline 109 & 138 & 136 & 137 & 139 \\
\hline 110 & 140 & 138 & 139 & 141 \\
\hline 111 & 142 & 140 & 141 & 143 \\
\hline 112 & 144 & 142 & 143 & 145 \\
\hline 113 & 146 & 144 & 145 & 147 \\
\hline 114 & 148 & 146 & 147 & 149 \\
\hline 115 & 150 & 148 & 149 & 151 \\
\hline & $\begin{array}{l}152 \\
151\end{array}$ & 150 & 103 & 105 \\
\hline 117 & 153 & 152 & 105 & 107 \\
\hline 118 & 154 & 153 & 107 & 109 \\
\hline 119 & 155 & 154 & 109 & 111 \\
\hline 120 & 156 & 155 & 111 & 113 \\
\hline 121 & 158 & 157 & 114 & 115 \\
\hline 122 & 159 & 158 & 115 & 116 \\
\hline 123 & 160 & 159 & 116 & 117 \\
\hline 124 & 161 & 160 & 117 & 118 \\
\hline 125 & 162 & 161 & 118 & 119 \\
\hline 126 & 163 & 162 & 119 & 120 \\
\hline 127 & 164 & 163 & 120 & 121 \\
\hline-128 & 165 & $\begin{array}{l}164 \\
123\end{array}$ & $\begin{array}{l}121 \\
166\end{array}$ & 125 \\
\hline 29 & 168 & 166 & $\begin{array}{l}125 \\
169\end{array}$ & 127 \\
\hline
\end{tabular}


unlts.dat

\begin{tabular}{|c|c|c|c|c|}
\hline 130 & 171 & 169 & 127 & 129 \\
\hline 131 & 174 & 171 & 129 & 132 \\
\hline 132 & 177 & 174 & 132 & 134 \\
\hline 133 & 180 & 177 & 134 & 136 \\
\hline 134 & 183 & 180 & 136 & 138 \\
\hline 135 & 186 & 183 & 138 & 140 \\
\hline 136 & 189 & 186 & 140 & 142 \\
\hline 137 & 192 & 189 & 142 & 144 \\
\hline 138 & 194 & 192 & 144 & 146 \\
\hline 139 & 195 & 194 & 146 & 148 \\
\hline 140 & 197 & 195 & 148 & 150 \\
\hline 141 & 199 & 197 & 150 & 152 \\
\hline 142 & 170 & 168 & 169 & 171 \\
\hline 143 & 173 & 170 & 171 & 174 \\
\hline 144 & 176 & 173 & 174 & 177 \\
\hline 145 & 179 & 176 & 177 & 180 \\
\hline 146 & 182 & 179 & 180 & 183 \\
\hline 147 & 185 & 182 & 183 & 186 \\
\hline 148 & 188 & 185 & 186 & 189 \\
\hline 149 & 191 & 188 & 189 & 192 \\
\hline 150 & 193 & 191 & 192 & 194 \\
\hline-151 & 196 & $\begin{array}{l}193 \\
195\end{array}$ & 194 & 197 \\
\hline 152 & 198 & 196 & 197 & 199 \\
\hline-153 & $\begin{array}{l}200 \\
199\end{array}$ & 198 & 152 & 153 \\
\hline 154 & 201 & 200 & 153 & 154 \\
\hline 155 & 202 & 201 & 154 & 155 \\
\hline 156 & 167 & 165 & 166 & 168 \\
\hline-157 & 172 & $\begin{array}{l}167 \\
170\end{array}$ & 168 & 173 \\
\hline 158 & 175 & 172 & 173 & 176 \\
\hline 159 & 178 & 175 & 176 & 179 \\
\hline 160 & 181 & 178 & 179 & 182 \\
\hline 161 & 184 & 181 & 182 & 185 \\
\hline 162 & 187 & 184 & 185 & 188 \\
\hline 163 & 190 & 187 & 188 & 191 \\
\hline-164 & 230 & 227 & 191 & 193 \\
\hline & 190 & & & \\
\hline 165 & 232 & 230 & 193 & 196 \\
\hline 166 & 235 & 232 & 196 & 198 \\
\hline 167 & 238 & 235 & 198 & 200 \\
\hline 168 & 240 & 238 & 200 & 201 \\
\hline 169 & 203 & 240 & 201 & 202 \\
\hline-170 & 204 & 203 & 155 & 156 \\
\hline & 202 & & & \\
\hline 171 & 206 & 205 & 158 & 159 \\
\hline 172 & 207 & 206 & 159 & 160 \\
\hline 173 & 208 & 207 & 160 & 161 \\
\hline 174 & 209 & 208 & 161 & 162 \\
\hline 175 & 210 & 209 & 162 & 163 \\
\hline 176 & 211 & 210 & 163 & 164 \\
\hline 177 & 212 & 211 & 164 & 165 \\
\hline-178 & 213 & 212 & 165 & 167 \\
\hline & & & 214 & \\
\hline-179 & 216 & 214 & 167 & 175 \\
\hline & & 172 & & \\
\hline-180 & 218 & 216 & 175 & 178 \\
\hline & & & 219 & \\
\hline 181 & 222 & 219 & 178 & 181 \\
\hline 182 & 223 & 222 & 181 & 184 \\
\hline 183 & 226 & 223 & 184 & 187 \\
\hline 184 & 227 & 226 & 187 & 190 \\
\hline 185 & 221 & 218 & 219 & 222 \\
\hline
\end{tabular}




\begin{tabular}{|c|c|c|c|c|}
\hline-186 & 225 & $\begin{array}{l}221 \\
223\end{array}$ & 222 & 226 \\
\hline-187 & 229 & $\begin{array}{l}225 \\
227\end{array}$ & 226 & 230 \\
\hline 188 & 231 & 229 & 230 & 232 \\
\hline 189 & 234 & 231 & 232 & 235 \\
\hline 190 & 237 & 234 & 235 & 238 \\
\hline 191 & 239 & 237 & 238 & 240 \\
\hline 192 & 215 & 213 & 214 & 216 \\
\hline 193 & 217 & 215 & 216 & 218 \\
\hline 194 & 220 & 217 & 218 & 221 \\
\hline 195 & 224 & 220 & 221 & 225 \\
\hline 196 & 228 & 224 & 225 & 229 \\
\hline-197 & 233 & $\begin{array}{l}228 \\
231\end{array}$ & 229 & 234 \\
\hline 198 & 236 & 233 & 234 & 237 \\
\hline 199 & 241 & 236 & 237 & 239 \\
\hline 200 & 241 & 239 & 240 & 203 \\
\hline 201 & 254 & 241 & 203 & 204 \\
\hline 202 & 243 & 242 & 207 & 208 \\
\hline 203 & 244 & 243 & 208 & 209 \\
\hline 204 & 245 & 244 & 209 & 210 \\
\hline-205 & 246 & $\begin{array}{l}245 \\
211\end{array}$ & 210 & 212 \\
\hline 206 & 247 & 246 & 212 & 213 \\
\hline-207 & 248 & $\begin{array}{l}247 \\
215\end{array}$ & 213 & 217 \\
\hline 208 & 249 & 248 & 217 & 220 \\
\hline 209 & 250 & 249 & 220 & 224 \\
\hline 210 & 251 & 250 & 224 & 228 \\
\hline 211 & 252 & 251 & 228 & 233 \\
\hline 212 & 253 & 252 & 233 & 236 \\
\hline 213 & 254 & 253 & 236 & 241 \\
\hline-214 & 256 & $\begin{array}{l}255 \\
243\end{array}$ & 242 & 244 \\
\hline-215 & 257 & $\begin{array}{l}256 \\
245\end{array}$ & 244 & 246 \\
\hline 216 & 258 & 257 & 246 & 247 \\
\hline 217 & 259 & 258 & 247 & 248 \\
\hline 218 & 260 & 259 & 248 & 249 \\
\hline 219 & 261 & 260 & 249 & 250 \\
\hline 220 & 262 & 261 & 250 & 251 \\
\hline 221 & 263 & 262 & 251 & 252 \\
\hline 222 & 264 & 263 & 252 & 253 \\
\hline 223 & 265 & 264 & 253 & 254 \\
\hline-22.4 & 267 & $\begin{array}{l}266 \\
256\end{array}$ & 255 & 257 \\
\hline 225 & 268 & 267 & 257 & 258 \\
\hline 226 & 269 & 268 & 258 & 259 \\
\hline-227 & 270 & $\begin{array}{l}269 \\
260\end{array}$ & 259 & 261 \\
\hline 228 & 271 & 270 & 261 & 262 \\
\hline 229 & 272 & 271 & 262 & 263 \\
\hline 230 & 273 & 272 & 263 & 264 \\
\hline 231 & 274 & 273 & 264 & 265 \\
\hline 232 & 276 & 275 & 266 & 267 \\
\hline-233 & 277 & $\begin{array}{l}276 \\
268\end{array}$ & 267 & 269 \\
\hline-234 & 278 & $\begin{array}{l}277 \\
270\end{array}$ & 269 & 271 \\
\hline 235 & 280 & 279 & 275 & 276 \\
\hline 236 & 281 & 280 & 276 & 277 \\
\hline 237 & 282 & 281 & 277 & 278 \\
\hline-238 & 283 & 282 & 271 & 272 \\
\hline
\end{tabular}


URIES.dat

$\begin{array}{rrrrr}239 & 278 & & & \\ 240 & 284 & 283 & 272 & 273 \\ 241 & 287 & 284 & 273 & 274 \\ -242 & 288 & 287 & 279 & 280 \\ & & 281 & & 282 \\ -243 & 289 & 288 & 282 & 284 \\ 244 & 290 & 289 & 284 & 285 \\ 245 & 291 & 294 & 286 & 287 \\ 246 & 292 & 291 & 287 & 288 \\ 247 & 293 & 292 & 288 & 289 \\ 248 & 296 & 293 & 289 & 290 \\ 249 & 295 & 294 & 291 & 292 \\ 250 & 296 & 295 & 292 & 293\end{array}$


ל.

0.0

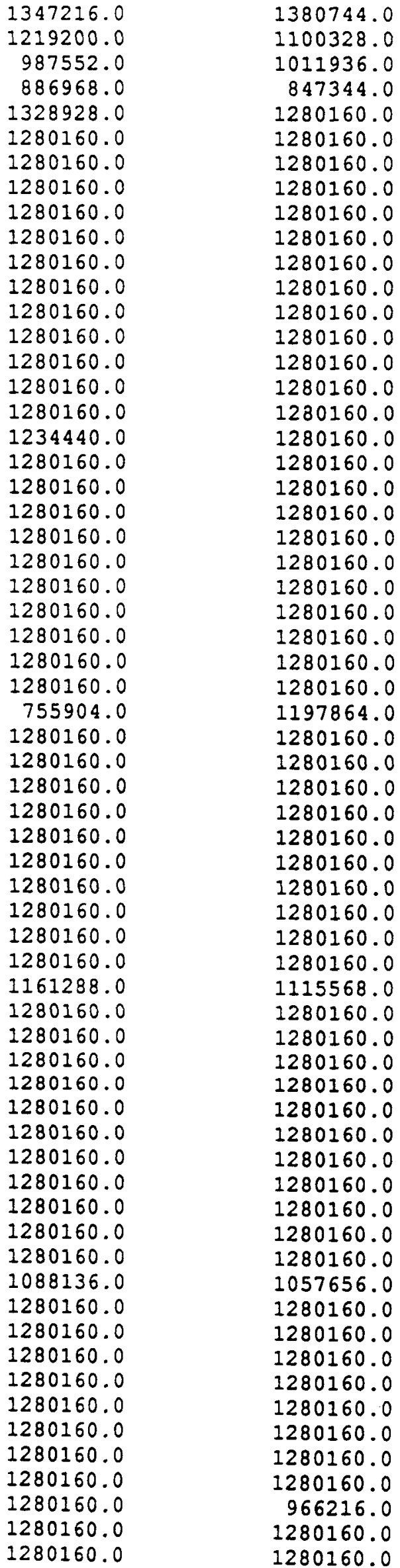

1322832.0

1045464.0

1005840.0

835152.0

1280160.0

1280160.0

1280160.0

1280160.0

1280160.0

771144.0

1280160.0

1280160.0

1280160.0

1280160.0

1280160.0

1280160.0

1280160.0

1280160.0

1280160.0

1280160.0

1280160.0

1280160.0

1280160.0

1280160.0

1280160.0

1280160.0

1280160.0

1280160.0

1280160.0

1280160.0

1280160.0

1280160.0

1280160.0

1280160.0

1280160.0

1280160.0

1280160.0

1280160.0

1280160.0

1280160.0

1280160.0

1280160.0

1280160.0

1280160.0

1280160.0

1280160.0

1280160.0

1280160.0

1280160.0

1280160.0

1280160.0

1018032.0

1280160.0

1280160.0

1280160.0

1280160.0

1280160.0

1280160.0

1280160.0

1280160.0

1280160.0

1280160.0

1280160.0
1292352.0 984504.0

941832.0

777240.0

1280160.0

1280160.0

1280160.0

1280160.0

1280160.0

1280160.0

1280160.0

1280160.0

1280160.0

1280160.0

1280160.0

1280160.0

762000.0

1280160.0

1280160.0

1280160.0

1280160.0

1280160.0

1280160.0

1280160.0

1280160.0

1280160.0

1280160.0

1280160.0

1280160.0

1280160.0

1280160.0

1280160.0

1280160.0

1280160.0

1280160.0

1280160.0

1280160.0

1280160.0

746760.0

1280160.0

1280160.0

1280160.0

1280160.0

1280160.0

1280160.0

1280160.0

1280160.0

1280160.0

1280160.0

1280160.0

746760.0

1280160.0

1280160.0

1280160.0

1280160.0

1280160.0

1280160.0

1280160.0

1280160.0

1280160.0

1280160.0

1280160.0

1280160.0 


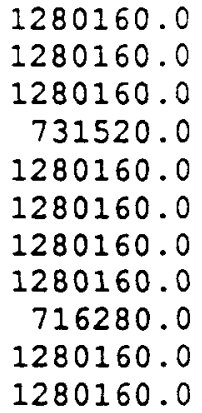

28.

80 .

80 .

48.

33 .

85.

75.

54.

54.

42.

53.

58.

45.

53.5

65.

60.

45.

58.

83.

56.

48.

60 .

69.

81.5

60.

55.

48.

44 .

30 .

80.

56.

50 .

48.

50 .

60.

85.

67.

55.

47.

80 .

78 .

48 .

48 .

50 .

40 .

56.

59.

75.

59.

54.

48 .

82 .

63.
746760.0

1280160.0

1280160.0

868680.0

1280160.0

716280.0

1280160.0

1280160.0

765048.0

716280.0

743712.0

33.5

83.

60 .

42.

45.

83.

67.

62 .

50 .

36.

64.

55.

43.

50 .

70 .

55.

49.5

76 .

80.

53.

48.

60 .

73.

75 .

58.

53.

46.

44 .

70 .

82.

58 .

51.

48.

53.

65.

67.

58.

54.

44.

85.

73.5

48.

49.

50 .

56.

58.

75.

70.

58.

54.

42.

82.

52 .
917448.0

1280160.0

1280160.0

1280160.0

1280160.0

838200.0

822960.0

1280160.0

1280160.0

1280160.0

731520.0

40.

80 .

50 .

36 .

70 .

83.

58.

62 .

46.

30 .

65.

50.

38.

45.

75 .

50 .

40.

95.

69.

48.

49.

65.

84.

70 .

58.

50 .

47.

42 .

85 .

75.

53.

47.

49.

66.5

55.

60.5

58 .

52.

41.

85.

63.

48.

49.

54.

55.

63.

80 .

60 .

56.

52.

41.

77.

48 .
1280160.0

1280160.0

1280160.0

1280160.0

1280160.0

1280160.0

1280160.0

1280160.0

1280160.0

1280160.0

716280.0

60.

83.

58.

30.

85.

88.5

52.

58.

44.

48 .

65 .

47.

67.

60.

70 .

47.

30 .

85.

60 .

48.

49.

68 .

77.

65.

57.

48.

45.

41.

93.

65.

51.5

47.

49.

58.

84.5

49.

56.

51.

30.

82.

52.

48.

50.

54.

59.5

70 .

75.

59.

57.

50.

30.

72.

48 . 
כנ. IOIC

49.

59.

68 .

74 .

73.

56.

53.

39.

48.

62.

46.

53.

56.

30.

61.

40.

54.

47.

30.

44.

33.
49.

60.

81.

76.

73.

58.

53.

65.

49.

45.

30 .

58.

62.

53.

55.

30 .

46.

45.

46.

31.

39.5
55.

58.

80.

74.

65.

58.

45.

57.

54.

56.

49.

62.

48 .

58.

48 .

59.

58.

40 .

44.

38.

34 .
53.5

63.

63.

64.

65.

52.

46.

50 .

60.

52.

49.

60.

43.

62.

44.

61.5

50 .

37 .

48.

34.

32. cemperatures. 